\title{
ilil $\begin{gathered}\text { IMAC } \\ \text { Editora }\end{gathered}$
}

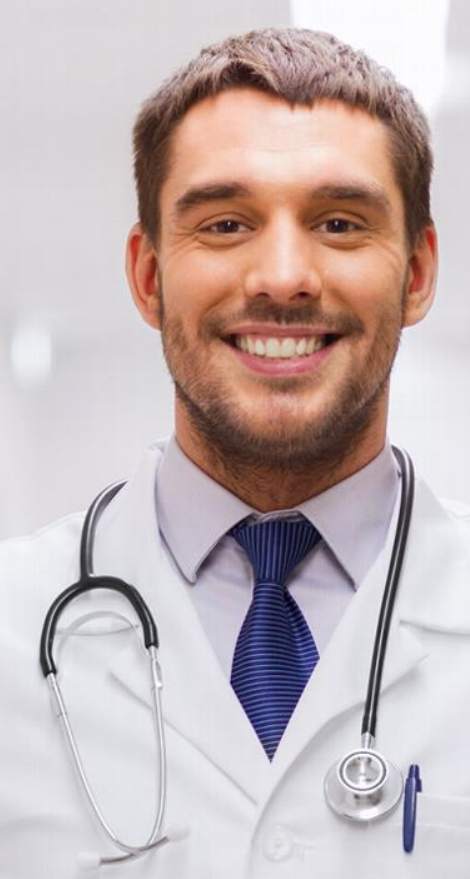

\section{Evidências em Ciências}

da Saúde: práticas,

desafios e perspectivas

Organizadoras:

Daniele Vasconcelos Fernandes Vieira Marcélid Berto da Costa

Emanuela Gomes Falcão 
Série Pesquisas em Ciências da Saúde, volume 3 
Organizadoras

Daniele Vasconcelos Fernandes Vieira

Marcélid Berto da Costa

Emanuela Gomes Falcão

\section{Evidências em Ciências da Saúde}

práticas, desafios e perspectivas

Volume 3

FORTALEZA

$\underline{\text { ilil IMAditora }}$

2021 
E93 Evidências em ciências da saúde: práticas, desafios e perspectivas /organizadoras, Daniele Vasconcelos Fernandes Vieira, Marcélid Berto da Costa, Emanuela Gomes Falcão - Fortaleza: IMAC, 2021. 3 v. - (Pesquisas em Ciências da Saúde; v. 3)

ISBN 978-65-995347-2-0

1. Enfermagem. 2. Atenção Primária à Saúde. 3. Cuidados Críticos. 4. Saúde da Mulher. 5. Saúde do Idoso. I. Vieira, Daniele Vasconcelos Fernandes. II. Costa, Marcélid da. III. Falcão, Emanuela Gomes. IV. Série.

CDD: 610.73

\section{Editora IMAC}

E-mail: contato@editoraimac.com.br

Site: www.editoraimac.com.br

\section{Direção Editorial}

Ivana Cristina Vieira de Lima Maia

\section{Conselho Editorial}

Prof. ${ }^{a}$ Dra. Cláudia Patrícia Mourão Lima Fontes

Prof. a Dra. Ivana Cristina Vieira de Lima Maia

Prof. ${ }^{a}$ M..$^{a}$ Daniele Vasconcelos Fernandes Vieira

Prof. M.e Francisco Regis da Silva

Prof.a Dra. Greicy Coelho Arraes

Prof. Dr. Helder Levi Silva Lima

Prof. ${ }^{a}$ M..$^{a}$ Isabelle Cerqueira Sousa

Prof. ${ }^{a}$ M..$^{a}$ Juliana Barbosa de Faria

Prof. ${ }^{a}$ Dra. Julyana Gomes Freitas

Prof. ${ }^{a}$ M. ${ }^{a}$ Malena Gadelha Cavalcante

Prof. a Dra. Niédila Nascimento Alves

Prof. ${ }^{a}$ M. ${ }^{a}$ Paula Pinheiro da Nóbrega

Prof. a Dra. Samyla Citó Pedrosa

Prof. ${ }^{a}$ Dra. Vanessa da Frota Santos

Prof.a. Dra. Virna Luiza de Farias

\section{Normalização Bibliográfica}

Paula Pinheiro da Nóbrega (CRB-3/717)

\section{Diagramação e Capa}

Helder Levi Silva Lima

\section{Organização}

Daniele Vasconcelos Fernandes Vieira; Marcélid Berto da Costa e Emanuela Gomes Falcão

Como citar esta obra: VIEIRA, Daniele Vasconcelos Fernandes; COSTA, Marcélid Berto da; FALCÃO, Emanuela Gomes (org.). Evidências em ciências da saúde: práticas, desafios e perspectivas. Fortaleza: IMAC, 2021. V. 3. (Série Pesquisas em Ciências da Saúde, v. 3). 


\section{Organizadora}

Prof. ${ }^{a}$ M. $^{a}$

Daniele Vasconcelos Fernandes Vieira

Enfermeira. Graduação pela Universidade Estadual do Ceará (UECE). Especialista em Terapias Holísticas e Complementares pela Faculdade IEducare. Mestra em Cuidados Clínicos em Enfermagem e Saúde pelo Programa de Pós-Graduação de Cuidados Clínicos em Enfermagem e Saúde (PPCCLIS) da Universidade Estadual do Ceará. Interesse de pesquisa e estudos na área de Ciências da Saúde com as temáticas de Promoção da Saúde; Bem-estar e Qualidade de Vida com enfoque em Práticas Integrativas e Complementares em Saúde no Sistema Único de Saúde (PICSSUS); Espiritualidade e Saúde; Linguagem, Cuidado e Comunicação na Saúde; Realidade Fractal e Ciência da Complexidade. Na área de Educação em

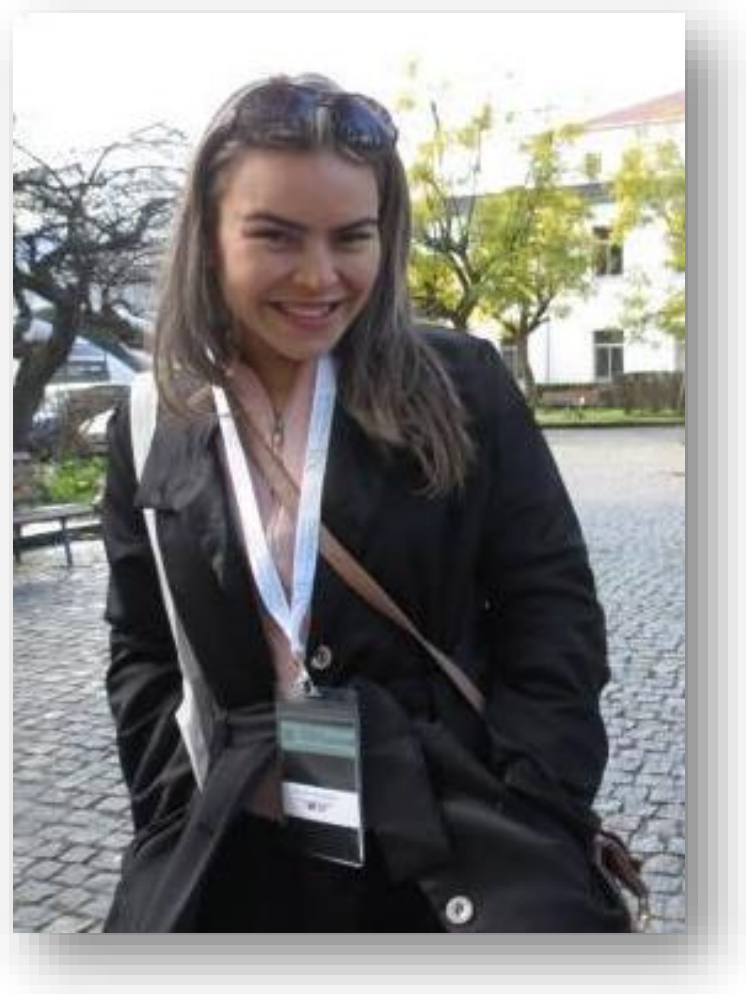
Saúde com ênfase na formação do profissional de nível técnico e superior; Formação Profissional em Práticas Integrativas e Complementares em Saúde. Atua na coordenação, qualificação e capacitação de Cursos de Terapias Holísticas/Integrativas e Complementares, na qualidade de Especialidades e/ou Aperfeiçoamentos. Atua na Coordenação de Grupos de Estudos, Pesquisa e de Práticas sobre essas temáticas. Membro da Associação dos Jovens de Irajá (AJIR) nos anos de 2010 a 2014. Membro do Conselho Fiscal da Associação Brasileira de Enfermagem (Aben)-Seção Ceará (2017-2019). Membro da Comissão de Práticas Integrativas em Saúde do Conselho Federal de Enfermagem Cpics-Cofen (2018-2020). Atualmente, contribui como avaliadora de Cursos Técnicos Profissionalizantes do Conselho Estadual de Educação do Ceará (início em 2017) e como avaliadora do Banco de Avaliadores (BASis) do Sistema Nacional de Avaliação da Educação Superior (Sinaes) (início em 2018). Ocupa o cargo de professora temporária da Faculdade Veterinária da Universidade Estadual do Ceará (FAVET- UECE).

E-mail: daniele.vieira@uece.br

Lattes: http:/ / lattes.cnpq.br/3649870369145728 


\section{Organizadora}

Prof.a M.a

Marcélid Berto da Costa

Bacharel em Enfermagem pela Universidade de Fortaleza (UNIFOR) (2007). Mestra em Ensino na Saúde (UECE) Especialista em Saúde da Família pela Universidade Estadual do Ceará (UECE). Especialista em Educação Profissional, científica e tecnológica (IFCE). Possui experiência profissional nas áreas de ensino (Gestão, Preceptoria e Docência) e na prática assistencial de Enfermagem (Clínica Médica e Cirúrgica). Atua como coordenadora e docente do Curso Técnico de Enfermagem

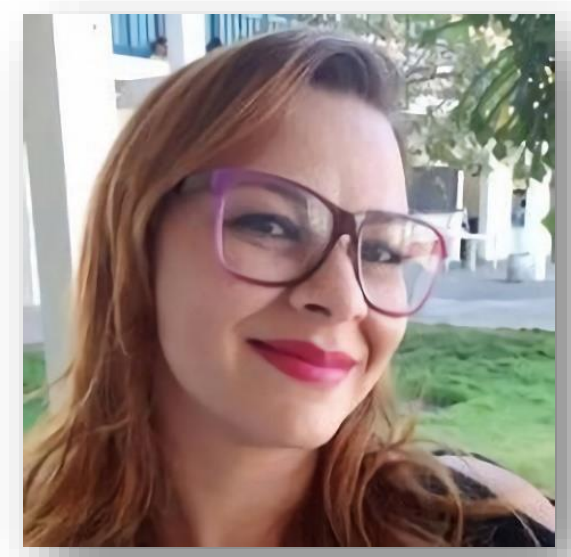
da Escola Estadual de Educação Profissional Ícaro de Sousa Moreira e integrou a equipe de apoio pedagógico do Programa Nacional de Acesso ao Ensino Técnico e Emprego (Pronatec)/Fundação Universidade Estadual do Ceará (Funece) nos anos de 2016 a 2018.

E-mail: marcelidberto@gmail.com

Lattes: http:/ / lattes.cnpq.br/8160103683997296 


\section{Organizadora}

Prof. ${ }^{a} \mathbf{M}^{\mathrm{a}}$

Emanuela Gomes Flacão

Possui graduação em Enfermagem pela Universidade de Fortaleza (UNIFOR) e graduação em Ciências Contábeis pela Universidade Estadual do Ceará (UECE). Pós-Graduada em Enfermagem Obstétrica pela UECE e em Transplante de Órgãos pela UECE. Mestrado em Saúde da Criança e do Adolescente pela UECE. Atuou como preceptora na Residência Multiprofissional com ênfase em Enfermagem Obstétrica na Escola de Saúde Pública do Ceará (campo de estágio no Hospital Geral Dr. César Cals). Professora convidada da Especialização em Enfermagem Obstétrica da UECE. Atua nas seguintes áreas: Sala de Parto; Emergências Obstétricas; Administração e Ciências Contábeis. Linhas de pesquisa: Saúde da Mulher; Enfermagem Obstétrica e COVID-19.

E-mail: gomes@live.com

Lattes: http:/ / lattes.cnpq.br/6370444847597480

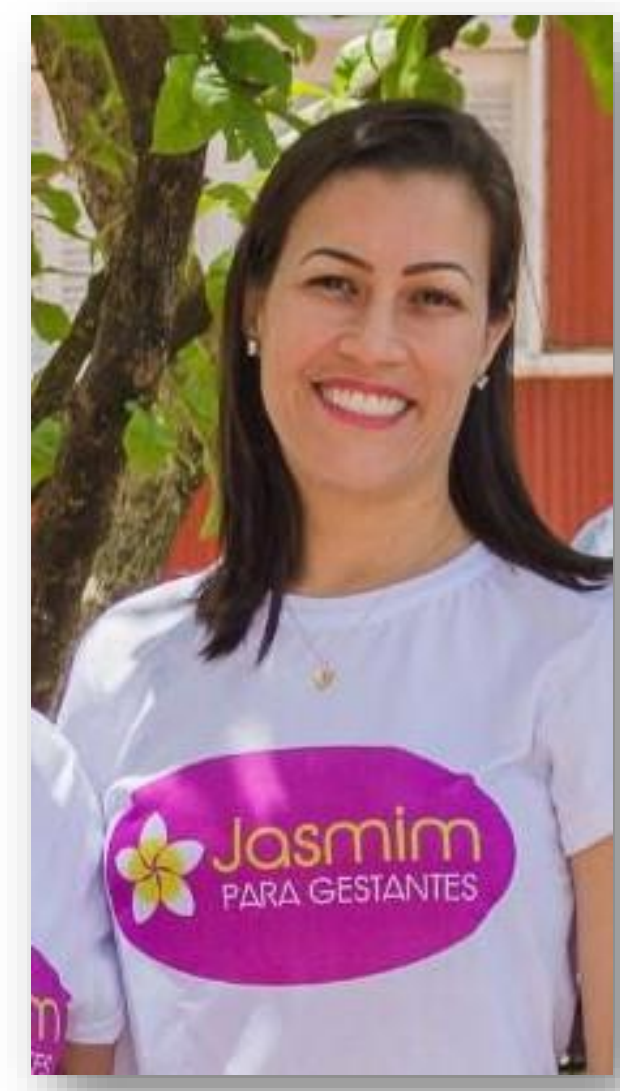




\title{
SUMÁRIO
}

\author{
APRESENTAÇÃO \\ 1 ESGOTAMENTO PROFISSIONAL EM ENFERMEIROS DE \\ UNIDADES DE TERAPIA INTENSIVA: REVISÃO INTEGRATIVA
}

Samara Soares Silva; Adriana Sousa Carvalho de Aguiar; Ana Ofélia Portela Lima; Francisca Andréa Marques de Albuquerque

2 ALEITAMENTO MATERNO NO BEBÊ COM CARDIOPATIA CONGÊNITA: A ESCUTA DA

MÃE

Joana Angélica Marques Pinheiro; Thereza Maria Magalhães Moreira; Márcia Maria Tavares Machado; Marília Ximenes Freitas Frota; Andressa Alencar Gondim; Vera Lúcia Mendes de Paula Pessoa

3 RISCO DE QUEDAS EM IDOSOS E O PAPEL DA FAMÍLIA: UMA REVISÃO INTEGRATIVA

Levi Paulo da Costa; Ivana Cristina Vieira de Lima Maia

4 REPERCUSSÕES DO CONTEXTO DE TRABALHO DO ENFERMEIRO NAS SUAS DIMENSÕES DE VIDA

Brenda Rayane Carneiro; Daniele Vasconcelos Fernandes Vieira; Franscica Gomes Montesuma; Ivando Amancio da Silva Júnior; Gislene Holanda de Freitas; André Ribeiro de Castro Júnior

5 ENVELHECIMENTO NA PÓS-MODERNIDADE: O QUE A PSICOLOGIA TEM A VER COM ISSO?.

Ticyane Candeia Ribeiro Sousa Olímpio; Fernando Antonio Carvalho Costa; Selene Regina Mazza; Daniele Vasconcelos Fernandes Vieira; Terezinha Almeida Queiroz

6 CONHECIMENTO DOS MANIPULADORES SOBRE BOAS PRÁTICAS DE MANIPULAÇÃO EM UMA UNIDADE DE ALIMENTAÇÃO NO MUNICIPIO DE MARACANAÚ

Nágilla Karine Braga; Larissa Pereira Aguiar; Daniele Vasconcelos Fernandes Vieira

7 DIREITOS DA MULHER NO PERÍODO GRAVÍDICOPUERPERAL

Débora Feijó Horta; Anderson Jack Franzen

8 PRÁTICA MEDITATIVA NA PROMOÇÃO DA SAÚDE DE PESSOAS VIVENDO COM HIV/AIDS: UMA REVISÃO INTEGRATIVA

Emanuele Ribeiro Ramos; Petronio Silva de Oliveira; Daniele Vasconcelos Fernandes Vieira; Jeania Lima Oliveira; Terezinha Almeida Queiroz; Alessandra Luzia Alves do Nascimento Celedônio 
9 PRÁTICA DA FITOTERAPIA POR NUTRICIONISTAS E PROFISSIONAIS DE SAÚDE NO SISTEMA ÚNICO DE SAÚDE NO BRASIL: UMA ANÁLISE DE 10 ANOS ....

Mítia Paiva Mota; Patricia Fernandes da Silveira; Daniele Vasconcelos Fernandes Vieira; Karlivania Martins Cardoso; Layla Wynny Aragão Lima Martins; Mayara de Matos Morais Monteiro

10 ANÁLISE DO DISCURSO DE MULHERES EM RELAÇÃO A SUA DECISÃO DE PARIR NA PERSPECTIVA FOUCAULTIANA DE GOVERNAMENTALIDADE SOBRE OS CORPOS

Cadidja Caldas Silva; Daniele Vasconcelos Fernandes Vieira; Terezinha Almeida Queiroz; Francisca Heronildes Patrício Caetano.; Ana Paula da Silva Morais; Marcélid Berto da Costa

11 IMPORTÂNCIA DA AMBIÊNCIA PARA HUMANIZAÇÃO DA SALA DE PARTO

Raiza Verônica Almeida Barbosa; Daniele Vasconcelos Fernandes Vieira; Ana Paula da Silva Morais; Tatiana Paschoalette Rodrigues Bachur; Gislene Holanda de Freitas; Marcélid Berto da Costa

12 PERCEPÇÃO DO PROFESSOR DE EDUCAÇÃO FÍSICA SOBRE A INSERÇÃ̃O DAS PRÁTICAS INTEGRATIVAS E COMPLEMENTARES EM SAÚDE NO CONTEXTO ESCOLAR NO MUNICÍPIO DE MARACANAÚ- CE

Sabrina Cavalcante Rodrigues; Daniele Vasconcelos Fernandes Vieira; Cláudio Henrique Couto do Carmo; Emanuele Ribeiro Ramos; Jeania Lima Oliveira; Marcos Aurélio Silva de Sousa

13 EDUCAÇÃO FÍSICA ESCOLAR E DROGAS: UMA ANÁLISE A LUZ DA TEORIA MARXISTA

Marcos Aurélio Silva de Sousa; Maria Eleni Henrique da Silva; Otávio Nogueira Balzano; Marcos Antônio Almeida Campos; Daniele Vasconcelos Fernandes Vieira; Sabrina Cavalcante Rodrigues

14 SEGURANÇA DO PACIENTE: GASOMETRIA COMO BOAS PRÁTICAS NA ASSISTÊNCIA DO ENFERMEIRO

Jennifer Késsya Rebouças de Oliveira; Daniele Vasconcelos Fernandes Vieira; Gislene Holanda de Freitas; Ivando Amâncio da Silva Júnior; Camila Pimentel de Souza; Elisângela Tavares da Silva

15 CORPO FEMININO E SUA RELAÇÃO COM OS MODOS DE CUIDAR DE SI: ANÁlISE ESTÉTICA NA PERSPECTIVA DE MULHERES PRATICANTES DE CROSSFIT

Ticyane Candeia Ribeiro Sousa Olimpio; Daniele Vasconcelos Fernandes Vieira; Marcélid Berto da Costa; Francisco Régis da Silva; Ana Paula da Silva Morais

16 UTILIZAÇÃO DAS BOAS PRÁTICAS AO PARTO E NASCIMENTO REALIZADA POR ENFERMEIROS OBSTETRAS

Jhonny Ferreira Neco; Lorenna Landim Farias de Queiroz; Bruna Nunes Costa Lima Rosado; Natália de Abreu Alcântara; Valéria Pereira da Silva; Emanuela Gomes Falcão 


\section{APRESENTAÇÃO}

Temos a grata satisfação de compartilhar com a comunidade acadêmica o E-book intitulado "Evidências em Ciências da Saúde: Práticas, Desafios e Perspectivas", volume 3. O E-book é composto de 16 pesquisas realizadas por autores de diferentes categorias profissionais da área da Saúde e afins, a saber: Educação Física, Enfermagem, Medicina, Nutrição e Psicologia. Cada capítulo retrata de forma representativa realidades vivenciadas em cenários díspares, seja na academia de ginástica, escola, hospital ou unidades de saúde.

A diversidade de saberes e a integralidade é a marca desse E-book, com destaque para a abordagem de temas fundamentais para a melhoria da assistência prestada na área da Saúde no que tange a: aleitamento materno; saúde mental de profissionais; prevenção de quedas em idosos; práticas de segurança alimentar; saúde sexual e reprodutiva; fitoterapia no âmbito do Sistema Único de Saúde (SUS); humanização da assistência em saúde; práticas integrativas e complementares; abuso de drogas ilícitas; atividade física e estética corporal.

Desejamos a todos uma excelente leitura! Esperamos que as evidências apresentadas neste E-book possam proporcionar a atualização de profissionais da área da Saúde e afins, com vistas ao avanço do conhecimento na área das Ciências da Saúde para proporcionar uma assistência de melhor qualidade no âmbito do SUS.

Ivana Cristina Vieira de Lima Maia Editora Chefe 


\section{1}

Esgotamento profissional em enfermeiros de unidades

de terapla intensiva: Revisão integrativa 


\title{
1 ESGOTAMENTO PROFISSIONAL EM ENFERMEIROS DE UNIDADES DE TERAPIA INTENSIVA: REVISÃO INTEGRATIVA
}

\author{
Samara Soares Silva \\ Adriana Sousa Carvalho de Aguiar \\ Ana Ofélia Portela Lima \\ Francisca Andréa Marques de Albuquerque
}

\section{Resumo}

Introdução: Os enfermeiros na atualidade representam uma classe de trabalhadores vulneráveis ao burnout por conta do excesso de sobrecarga de trabalho e de exigências quantitativas, problemas na comunicação com a equipe, falta de condições no ambiente de trabalho. É necessário que ocorra uma procura pela prevenção da sua saúde mental. Objetivo: identificar os fatores desencadeantes do esgotamento profissional no ambiente de terapia intensiva e as repercussões disso para a saúde do enfermeiro. Métodos: Trata-se de um estudo descritivo, fazendo uso do método de revisão integrativa da literatura para se obter e analisar dados, a partir de artigos publicados nos últimos 5 anos na base de dados Literatura Latino-Americana e do Caribe em Ciências da Saúde (LILACS) e The Scientific Electronic Library Online (SciELO). Foram utilizados como descritores de assunto: Esgotamento profissional; Enfermeiras e Enfermeiros; Unidades de Terapia Intensiva, associados entre si pelo operador booleano $A N D$. Restaram 5 artigos que atenderam aos critérios de inclusão e exclusão. Resultados/Discussão: A amostra do estudo foi composta por 5 artigos, observou-se que a maioria dos artigos são recentes tendo uma maior predominância no ano de 2017, percebe-se assim que o esgotamento profissional é um assunto novo a ser abordado e estudado pela comunidade científica. Notase que as Unidades de Terapia Intensiva possuem muitos fatores que predispõem o esgotamento profissional e as consequências negativas na vida desses profissionais. Conclusão: Conclui-se que a enfermagem em UTI é mais propensa ao desenvolvimento de burnout tendo em vista as próprias características do seu trabalho, surtindo assim impactos negativos na vida desses profissionais que vão de depressão a vícios.

Palavras-Chave: Esgotamento Profissional. Enfermeiras e Enfermeiros. Unidades de Terapia Intensiva. 


\section{Introdução}

O esgotamento profissional também conhecido na literatura como Síndrome de Burnout (SB) ou Síndrome de Esgotamento Profissional é caracterizada pelo estresse emocional que atinge os profissionais, sendo mais comum na área da saúde, é considerada uma doença do trabalho. O esgotamento é caracterizado por exaustão emocional (EE), redução da realização pessoal (RP) no trabalho e despersonalização do outro (FERNANDES; NITSCHE; GODOY, 2018).

A SB é caracterizada por uma junção de sintomas físicos e psicológicos, tendo três dimensões: exaustão emocional, que é a perda de habilidades emocionais para lidar com a sua profissão, despersonalização sendo um conjunto de cinismo, atitudes negativas e frieza para com os clientes do serviço e falta de realização pessoal onde se tem o profissional depreciando o seu próprio trabalho e tendo uma baixa autoestima. Logo, as consequências dessa síndrome são uma baixa qualidade do serviço, aumento de ausência do profissional no trabalho, aumento da rotatividade e acabam sendo mais suscetíveis a acidentes de trabalho (GARCIA; MARZIALE, 2018).

Estudos realizado por Silva et al. (2017) apontam que o enfermeiro é um dos principais profissionais a terem a SB e esse esgotamento acaba tendo como consequência direta na baixa qualidade prestada ao cliente. Alguns exemplos que podem acabar ocorrendo são: indiferença para com os seus pacientes e colegas de trabalho, desmotivação e frustação. Os enfermeiros acabam adoecendo por conta de sua própria atividade, tendo como estressores longos turnos de trabalho, horas extras, lidar diretamente e a toda hora com outras pessoas (SILVA et al., 2017).

A SB está conectada diretamente com a atividade profissional da pessoa, sendo assim pode acarretar doenças cardíacas, transtornos do sono, depressão e ansiedade. Logo é dito que estresses dentro do próprio ambiente de 
trabalho que persistem ao longo do tempo podem levar o indivíduo a ter Síndrome de Burnout (MODESTO; SOUZA; RODRIGUES, 2020).

Os enfermeiros na atualidade representam uma classe de trabalhadores vulneráveis ao burnout por conta do excesso de sobrecarga de trabalho e de exigências quantitativas, problemas na comunicação com a equipe, falta de condições no ambiente de trabalho. É necessário que ocorra uma procura pela prevenção da sua saúde mental, sendo assim preciso a inclusão de intervenções que interfiram a favor da saúde psicológica desses trabalhadores a fim de que eles tenham satisfação com o seu trabalho e o ambiente dele. É importante que os enfermeiros tenham a capacidade de cuidarem de si mesmo e de se valorizarem ajudando dessa forma a reduzir o stress e consequentemente o burnout (FARIA et al., 2019).

A descompensação psíquica ocorre por conta do não reconhecimento do trabalho levando-o a ter uma diminuição da realização profissional caracterizando posteriormente na despersonalização (FERNANDES; NITSCHE; GODOY, 2018). Essa despersonalização nada mais é do que uma resposta impessoal e sem sentimento algum para com o usuário do serviço de saúde, expressada através de atitudes frias e acompanhadas de pensamentos negativos (FARIA et al., 2019).

É visto que na prática da UTI o ambiente influência as condições de saúde dos profissionais, tanto físicas quanto psicológicas. O esgotamento profissional atinge não apenas a pessoa de forma individual, mas também o coletivo do trabalho, sendo essa a consequência deste problema. Estudos com a temática de saúde do trabalhador no nosso país veem se tornando populares, já que para que se obtenha uma assistência adequada, segura e qualificada, é necessário que se tenha a satisfação dos trabalhadores e que eles estejam em condições de realizar esse serviço de qualidade. É notável a partir da leitura da literatura o indicativo que o desgaste emocional é potencialmente considerável como um dos fatores iniciais no esgotamento profissional, tendo em vista que a carga de trabalho, ambiente e as demandas interpessoais do trabalhador são fatores tidos nessa subescala (ALVES et al., 2021). 
$\mathrm{O}$ assunto abordado evidencia-se como um problema emergente de saúde pública, sendo assim importante o debate, tendo em vista a realidade difícil e complexa que esses profissionais estão vivendo atualmente, principalmente tendo na atualidade o combate incansável contra a pandemia do COVID 19, estimulando assim a análise a partir das literaturas existentes acerca do esgotamento profissional em enfermeiros de UTI (LORENZ; SABINO; CORREA FILHO, 2018).

Diante disso, como forma de aprofundar o conhecimento acerca do assunto, o presente estudo tem como objetivo identificar os fatores desencadeantes do esgotamento profissional no ambiente de terapia intensiva e as repercussões disso para a saúde do enfermeiro.

\section{Objetivo}

Identificar na literatura os fatores desencadeantes do esgotamento profissional em enfermeiros no ambiente de terapia intensiva e as repercussões disso para a sua saúde.

\section{Metodologia}

Trata-se de um estudo descritivo, fazendo uso do método de revisão integrativa da literatura para se obter e analisar dados. Esta metodologia se aplica a partir da decisão do tema que será investigado, onde se terá uma procura, avaliação crítica e a síntese dessas evidências que estão acessíveis na literatura atual, tendo como objeto final a identificação de vulnerabilidades e o estabelecimento de intervenções que auxiliaram investigações futuras (SOUSA et al., 2017). Foram vistas as seguintes etapas: estabelecimento da pergunta norteadora e do tema, definição dos critérios de inclusão e exclusão, busca ou amostragem na literatura, coleta de dados, análise crítica dos estudos inseridos, 
discussão dos resultados, interpretação dos resultados e apresentação da revisão/síntese do conhecimento (MENDES; SILVEIRA; GALVÃO, 2008).

Foram estabelecidas as seguintes questões norteadoras para o estudo: Quais os fatores desencadeadores do esgotamento profissional no ambiente de terapia intensiva? Quais as repercussões disso para a saúde do enfermeiro?

Os dados foram obtidos no período de abril de 2021 a maio de 2021, o levantamento foi feito através da Biblioteca Virtual em Saúde (BVS), utilizando as bases de dados: Literatura Latino-Americana e do Caribe em Ciências da Saúde (LILACS) e The Scientific Electronic Library Online (SciELO). Para a estratégia de pesquisa foram utilizados descritores de assunto contidos nos Descritores em Ciências da Saúde (DeCS), sendo eles: Esgotamento profissional; Enfermeiras e Enfermeiros; Unidades de Terapia Intensiva. Foi utilizado o descritor operador booleano AND para cruzamento dos mesmos, sendo combinados da seguinte forma: Esgotamento Profissional AND Enfermeiras e Enfermeiros AND Unidades de Terapia Intensiva.

Para compor a amostra os estudos foram selecionados com base nos seguintes critérios de inclusão: ser artigo original, publicado no período de 2015 a 2020, em português, com textos completos e disponíveis na íntegra eletronicamente. Foram excluídos artigos repetidos, aqueles que não contemplavam a temática e/ou não atendiam o objetivo da pesquisa, de revisão, trabalhos de conclusão de curso, teses e dissertações, assim como aqueles que contemplassem outros ambientes de trabalho que não fosse a Unidade de Terapia Intensiva e que o público não fosse de enfermeiros.

Para a obtenção das informações dos artigos, estes estão dispostos em um quadro onde há tema e caracterização de alguns dados, tais como: base de dados, título, autor (es), objetivos, métodos, resultados mais relevantes e ano de publicação. Os artigos foram identificados pelo seu título e simbolizados pela letra "E" seguida de um número (Exemplo: E1, E2, E3...).

$\mathrm{Na}$ etapa de avaliação foi realizada análise por meio de leitura na íntegra dos estudos selecionados. Para a discussão com base nos resultados dos artigos, esta será organizada em duas categorias: Fatores desencadeadores do 
esgotamento profissional no ambiente de terapia intensiva e Repercussões para a saúde do enfermeiro.

O levantamento teve como resultado 7 publicações na base de dados, onde destas apenas 5 estavam dentro do período estabelecido do estudo, portanto 5 artigos foram selecionados, sendo 4 no SciELO e 1 no LILACS. O processo do levantamento de artigos é descrito na figura a seguir (Figura 1). 
Figura 1 - Processo de identificação, seleção, elegibilidade e inclusão de artigos. Fortaleza - CE, 2021

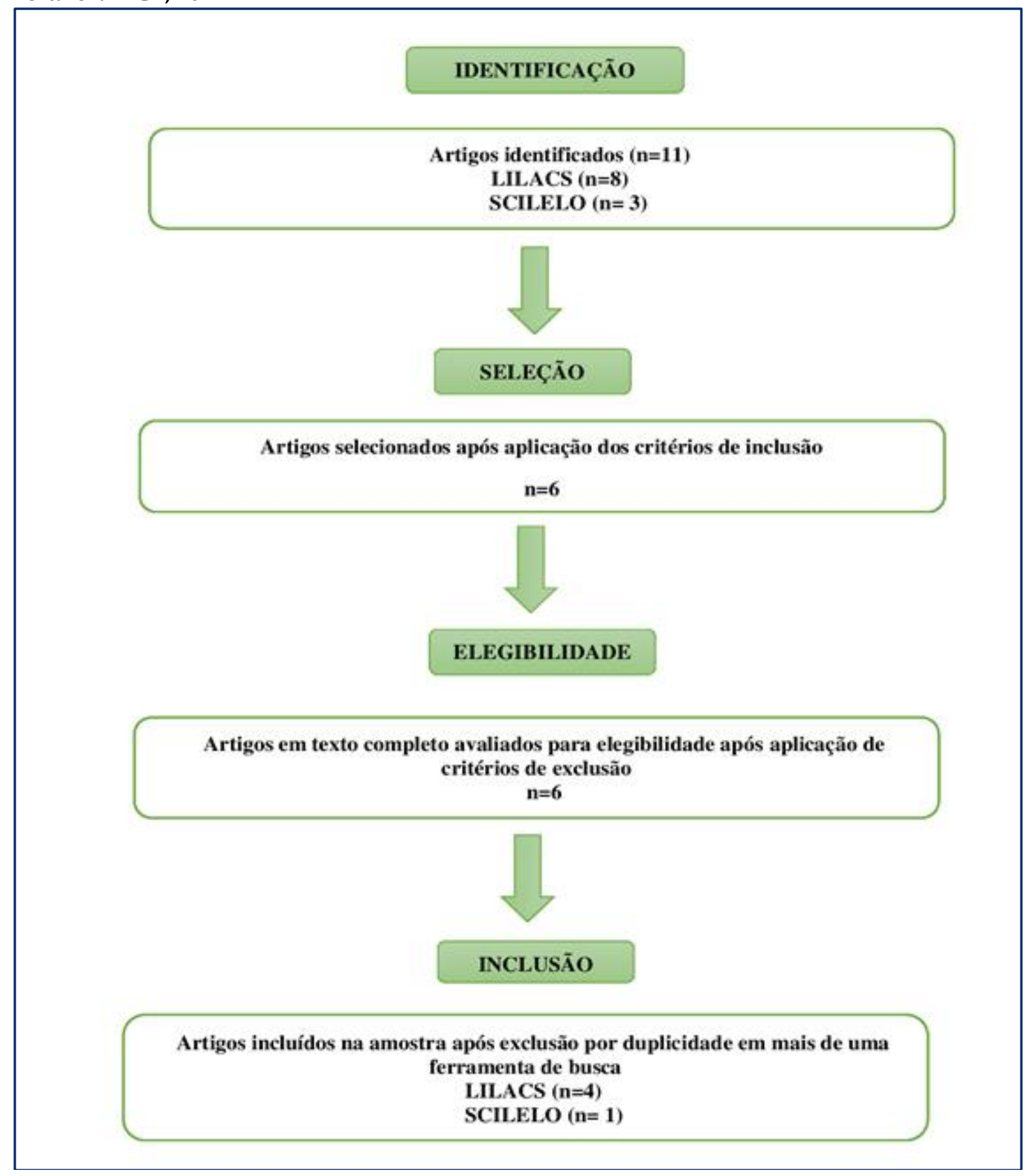

Fonte: Elaboração das autoras. 


\section{Resultados}

A amostra do estudo foi composta por 5 artigos, onde no Quadro 1 estão sendo apresentados os principais dados de caracterização como autoria e ano, periódico e base de dados, tipo de estudo, objetivo e principais resultados.

Quadro 1 - Distribuição dos estudos sobre o esgotamento profissional em enfermeiros de unidades de terapia intensiva segundo periódico, título, autoria, objetivo, método da pesquisa, principais resultados e ano de publicação

\begin{tabular}{|c|c|c|c|c|c|}
\hline Artigo & Autoria (Ano) & $\begin{array}{l}\text { Periódico/Biblioteca/ } \\
\text { Base de Dados }\end{array}$ & $\begin{array}{l}\text { Tipo de } \\
\text { Estudo }\end{array}$ & Objetivos & $\begin{array}{l}\text { Principais } \\
\text { Resultados }\end{array}$ \\
\hline E1 & $\begin{array}{l}\text { Silva et al. } \\
\text { (2015) }\end{array}$ & $\begin{array}{c}\text { Revista Brasileira de } \\
\text { Terapia } \\
\text { Intensiva/LILACS }\end{array}$ & $\begin{array}{l}\text { Descritivo } \\
\text { Seccional }\end{array}$ & $\begin{array}{l}\text { Descrever a } \\
\text { prevalência da } \\
\text { síndrome de } \\
\text { burnout entre } \\
\text { trabalhadores } \\
\text { de enfermagem } \\
\text { de unidades de } \\
\text { terapia } \\
\text { intensiva, } \\
\text { fazendo } \\
\text { associação a } \\
\text { aspectos } \\
\text { psicossociais. }\end{array}$ & $\begin{array}{l}\text { A prevalência de } \\
\text { síndrome de } \\
\text { burnout foi de } \\
55,3 \% \text { (n } \\
=72 \text { ). Quanto aos } \\
\text { quadrantes do } \\
\text { modelo demanda- } \\
\text { controle, a baixa } \\
\text { exigência } \\
\text { apresentou } 64,5 \% \text { de } \\
\text { casos prevalentes } \\
\text { suspeitos e a alta } \\
\text { exigência, } 72,5 \% \text { de } \\
\text { casos (p = 0,006). Foi } \\
\text { constatada a } \\
\text { prevalência de } \\
27,7 \% \text { de casos } \\
\text { suspeitos para } \\
\text { transtornos mentais } \\
\text { comuns; destes, } \\
80,6 \% \text { estavam } \\
\text { associados à } \\
\text { síndrome de } \\
\text { burnout. }\end{array}$ \\
\hline E2 & $\begin{array}{l}\text { Vasconcelos e } \\
\text { Martino (2017) }\end{array}$ & $\begin{array}{c}\text { Revista de } \\
\text { Enfermagem } \\
\text { Brasileira/LILACS }\end{array}$ & $\begin{array}{l}\text { Observacion } \\
\text { al, de corte } \\
\text { transversal. }\end{array}$ & $\begin{array}{l}\text { Analisar a } \\
\text { existência de } \\
\text { relação entre o } \\
\text { burnout e a } \\
\text { sintomatologia } \\
\text { depressiva em } \\
\text { enfermeiros de } \\
\text { unidade de }\end{array}$ & $\begin{array}{l}\text { Os profissionais } \\
\text { jovens são mais } \\
\text { propensos a } \\
\text { desenvolver a SB, } \\
\text { em virtude da } \\
\text { inexperiência de } \\
\text { trabalho e da não } \\
\text { adaptação às }\end{array}$ \\
\hline
\end{tabular}




\begin{tabular}{|c|c|c|c|c|c|}
\hline & & & & $\begin{array}{l}\text { terapia } \\
\text { intensiva. }\end{array}$ & $\begin{array}{l}\text { condições de } \\
\text { trabalho e das } \\
\text { organizações, } \\
\text { resultando má } \\
\text { qualidade do } \\
\text { cuidado. }\end{array}$ \\
\hline E3 & $\begin{array}{l}\text { Schallenber; } \\
\text { Tomaschews e } \\
\text { Ki-Barlem } \\
\text { (2019) }\end{array}$ & $\begin{array}{c}\text { Revista de } \\
\text { Enfermagem } \\
\text { Brasileira/LILACS }\end{array}$ & $\begin{array}{l}\text { Exploratório- } \\
\text { descritiva. }\end{array}$ & $\begin{array}{l}\text { Identificar, entre } \\
\text { enfermeiros de } \\
\text { Unidades de } \\
\text { Terapia } \\
\text { Intensiva, } \\
\text { problemas } \\
\text { éticos com base } \\
\text { nos } \\
\text { componentes da } \\
\text { sensibilidade } \\
\text { moral. }\end{array}$ & $\begin{array}{l}\text { A educação ética, o } \\
\text { diálogo, a relação } \\
\text { com os demais } \\
\text { membros da equipe } \\
\text { de saúde, a } \\
\text { autonomia } \\
\text { profissional, o } \\
\text { conhecimento, os } \\
\text { valores pessoais, a } \\
\text { comunicação } \\
\text { efetiva, a liderança e } \\
\text { os resultados } \\
\text { positivos } \\
\text { apresentados pelos } \\
\text { pacientes } \\
\text { constituem } \\
\text { importantes } \\
\text { componentes da } \\
\text { sensibilidade moral } \\
\text { dos enfermeiros, } \\
\text { compreendendo os } \\
\text { domínios da } \\
\text { consciência moral, } \\
\text { motivação } \\
\text { benevolente e } \\
\text { percepção moral } \\
\text { espontânea }\end{array}$ \\
\hline E4 & $\begin{array}{l}\text { Vasconcelos e } \\
\text { Martino (2017) }\end{array}$ & $\begin{array}{c}\text { Revista Gaúcha de } \\
\text { Enfermagem/ } \\
\text { SciELO }\end{array}$ & Transversal & $\begin{array}{l}\text { Identificar a } \\
\text { prevalência e } \\
\text { analisara } \\
\text { existência de } \\
\text { fatores } \\
\text { preditores da } \\
\text { síndromede } \\
\text { burnout em } \\
\text { enfermeiros de } \\
\text { unidade de } \\
\text { terapiaintensiva. }\end{array}$ & $\begin{array}{l}\text { Apresentaram } \\
\text { burnout } 14,3 \% \text { da } \\
\text { amostra. Das } \\
\text { variáveis estudadas, } \\
\text { a duração das férias } \\
\text { foi a única que } \\
\text { apresentou } \\
\text { associação } \\
\text { significativa com a } \\
\text { ocorrência do } \\
\text { burnout ( } p=0,034 / \\
\text { OR=3,92). }\end{array}$ \\
\hline E5 & $\begin{array}{l}\text { Fernandes; } \\
\text { Nitsche } \\
\text { e Godoy } \\
(2018)\end{array}$ & $\begin{array}{l}\text { Ciência \& Saúde } \\
\text { Coletiva/ } \\
\text { LILACS }\end{array}$ & $\begin{array}{l}\text { Estudo } \\
\text { bibliométric } \\
\text { o, } \\
\text { documental }\end{array}$ & $\begin{array}{l}\text { Verificar a } \\
\text { presençada } \\
\text { Síndromede } \\
\text { burnout entre } \\
\text { profissionais de } \\
\text { Enfermagem, } \\
\text { nasUnidades } \\
\text { de Terapia } \\
\text { Intensiva (UTI) }\end{array}$ & $\begin{array}{l}\text { Os profissionais } \\
\text { jovens são mais } \\
\text { propensos a } \\
\text { desenvolver a SB, } \\
\text { em virtude da } \\
\text { inexperiência de } \\
\text { trabalho e da não } \\
\text { adaptação às } \\
\text { condições de }\end{array}$ \\
\hline
\end{tabular}




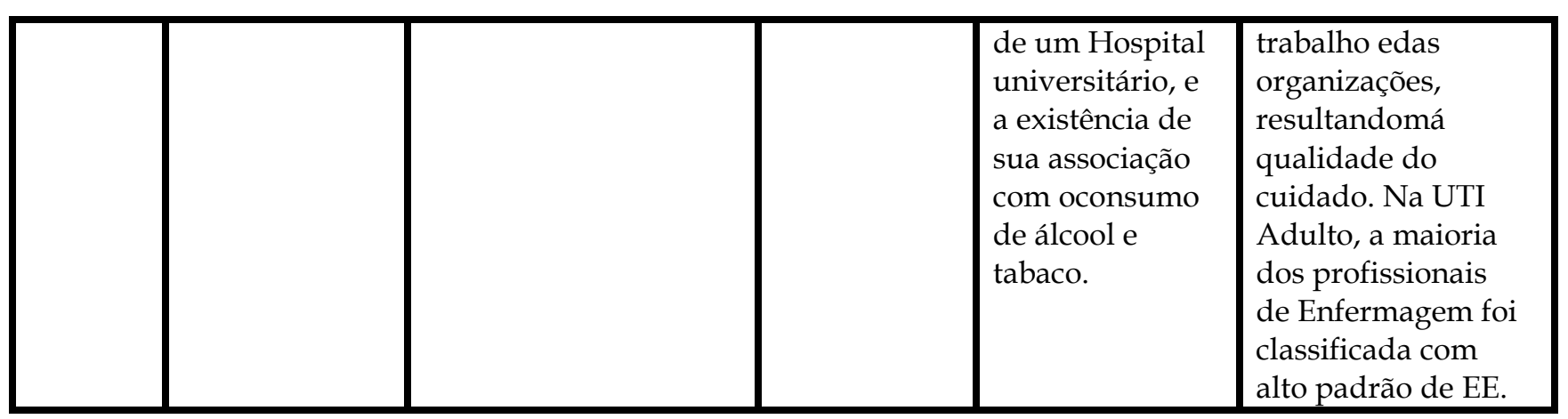

Fonte: Elaboração das autoras.

Quatro artigos foram publicados em revistas de enfermagem, sendo apenas um publicado em periódicos com demanda multidisciplinar na área da saúde. Observou-se que a maioria dos artigos são recentes tendo uma maior predominância no ano de 2017, percebe-se assim que o esgotamento profissional é um assunto novo a ser abordado e estudado pela comunidade científica.

A respeito da abordagem, quatro estudos eram quantitativos, apenas um era qualitativo, mostrando assim uma necessidade de se ter mais pesquisas qualitativas. Devido ao assunto tratado é de extrema necessidade que se tenha um estudo mais detalhado e observacional quanto aos comportamentos desses enfermeiros para que assim se tenha uma melhor compreensão acerca do que o profissional enfermeiro enfrenta, servindo também de base para pesquisas futuras.

Dando surgimento a duas categorias: fatores que predispõem o aparecimento do esgotamento profissional em enfermeiros de UTI e as consequências do esgotamento profissional na vida dos enfermeiros de UTI acometidos pelo esgotamento profissional. 


\section{Discussão}

Categoria 1: Fatores desencadeadores do esgotamento profissional no ambiente de unidade de terapia intensiva

Os artigos inclusos nesta categoria foram três e destacam sobre fatores psicossociais e preditores da síndrome de burnout. Os estudos expuseram dados sobre: a prevalência da síndrome em enfermeiros intensivistas e fatores que favorecem o aparecimento do burnout.

Foi observado que a diminuição da realização pessoal causa uma baixa produtividade e uma baixa realização no trabalho, sendo que o não apoio social e a falta de oportunidades para que o profissional possa se desenvolver ao longo do tempo potencializa de maneira negativa o esgotamento desse profissional. As UTI são os setores em que ocorre uma maior dificuldade de relacionamento interpessoal tanto dos profissionais com os familiares dos pacientes como entre os colegas de trabalho criando assim a vontade de escapar daquele trabalho, vale ressaltar também a sobrecarga de trabalho que se tem na UTI, normalmente a superlotação, espaço e materiais precários são algumas características que contribuem para essa baixa qualidade do trabalhador (SILVA et al., 2015).

Segundo um estudo realizado por Vasconcelos em 2017, foi encontrado alguns pontos divergentes com as demais literaturas disponíveis que abordam o esgotamento profissional, o mesmo afirma que os enfermeiros que possuem uma carga horaria de 30 horas semanais e que não possuem mais de um emprego são os que mais possuem síndrome de burnout, ao contrário do que está presente na literatura, onde falam que profissionais em dois trabalhos e carga horária elevada devido ao duplo vínculo empregatício eram mais suscetíveis ao esgotamento (VASCONCELOS; MARTINO, 2017).

A equipe de enfermagem quando comparada com outras profissões é mais propensa ao desenvolvimento de burnout tendo em vista as próprias 
características do seu trabalho, como, ser um grande responsável pela vida dos pacientes e por trabalhar de forma direta com os pacientes e seus familiares, onde estes estão inevitavelmente em sofrimento. A relação entre integridade do ego pessoal, padrões profissionais e a precisão constante do paciente na relação terapêutica acabam deixando os enfermeiros susceptíveis ao estresse, fadiga e esgotamento (SILVA et al., 2015).

A partir de um estudo realizado por Schallenberger et al. (2019), foi obtido que as relações entre os membros da equipe de saúde podem interferir diretamente nos cuidados prestados aos pacientes pois podem ocorrer divergências nas condutas tomadas pelos profissionais, fatores também como falta de autonomia no trabalho e a dependência de condutas médica podem caracterizar um sofrimento moral. Foi visto que muitos enfermeiros das unidades de saúde intensiva reconhecem esses problemas éticos, mas, não são capazes de mudar essa realidade onde trabalham.

A SB é um processo que vai progredindo negativamente em um período de 10 anos em um ambiente com fatores que a predispõem, tendo uma maior probabilidade de aumento após esse tempo (SILVA et al., 2015)

Porém, o estudo feito por Vasconcelos e Martino (2017) aponta que os profissionais com menos tempo no local de trabalho tendem a apresentar um maior nível de esgotamento devido a altas expectativas que não são atingidas, desesperança para que a situação melhore juntamente com atitude e sentimentos negativos. A enfermagem exige um intenso relacionamento interpessoal para que se tenha uma qualidade positiva prestada ao cliente, porém, esses trabalhadores acabam se sobrecarregando e aliado com a falta de recursos para atendimento de uma alta demanda acabam não vendo mais sentido no seu trabalho.

Sendo assim, notou-se a partir das literaturas selecionadas que ainda não há um consenso entre elas sobre quais fatores de fato levam ao esgotamento profissional nos enfermeiros. 
Categoria 2: Repercussões do ambiente de trabalho para a saúde do enfermeiro

Nesta categoria foram utilizados dois artigos, os quais abordavam as relações entre a depressão, alcoolismo e tabagismo com a síndrome de burnout.

A influência dos fatores estressores que é tido nas unidades de terapia intensiva como pressão e sobrecarga de trabalho acabam levando o profissional ao esgotamento físico e emocional que como consequência prejudica sua qualidade de vida e a qualidade de atendimento aos pacientes, assim, se tem com decorrência uma maior rotatividade e uma falta as obrigações habituais do trabalho, como pontualidade e motivação para realizar suas funções interferindo assim no ambiente de trabalho (FERNANDES; NITSCHE; GODOY, 2018).

Entende-se que a grande prevalência existente da SB em enfermeiros de unidade de terapia intensiva tem uma forte associação com a sintomatologia depressiva. Por muitas vezes o burnout acaba sendo diagnosticado erroneamente como depressão, tendo como consequência um tratamento que não irá surtir efeito nesses profissionais acometidos, tendo em vista que a depressão tem sua fisiopatologia relacionada a um trauma intrínseco e o burnout tem sua fisiopatologia relacionada ao local de trabalho (VASCONCELOS; MARTINO; FRANÇA, 2018).

Quando não ocorre diálogo com a chefia para tentar minimizar de alguma forma os fatores estressores dentro do local de trabalho, que ocasionam o esgotamento profissional o enfermeiro acaba tendo mecanismos de defesa afim de diminuir esses estressores para esconder de uma forma rasa a ansiedade grave adquirida através do trabalho, como uso de álcool e cigarro (FERNANDES; NITSCHE; GODOY, 2018).

No presente artigo estudado de Vasconcelos; Martino e França (2018), foi observado que na literatura atual acredita-se que o burnout prevê a sintomatologia depressiva, sendo assim, a depressão pode surgir devido a síndrome. As prevalências da SB juntamente com a sintomatologia depressiva são bem altas, segundo os autores do artigo. A Política Nacional de Saúde do Trabalhador não consegue suprir e ajudar os profissionais que passam por este 
problema. É necessário que se faça adoções de medidas que ajudem no enfrentamento a SB e a sintomatologia depressiva já que isto interfere nos cuidados concedidos aos pacientes (VASCONCELOS; MARTINO; FRANÇA, 2018).

Considerando o estresse contido no ambiente de UTI, o qual solicita dos profissionais um trabalho mais árduo, contribuindo para o estabelecimento da SB, foi visto como escape uma certa porcentagem dos enfermeiros entrevistados para o estudo consumiam álcool e, dentre estes, faziam um consumo em excesso, o que acabava refletindo negativamente no seu trabalho. Foi observado também o uso de tabaco em excesso dentre os profissionais, ocasionados pela exaustão emocional, redução de realização profissional e despersonalização, características que compõe o esgotamento profissional (FERNANDES; NITSCHE; GODOY, 2018).

Diante do exposto, as consequências do esgotamento profissional para a saúde dos profissionais de enfermagem devem servir como alerta para gestores, instituições empregadoras e órgãos de pesquisa, para que assim se criem estratégias efetivas como forma de prevenção e como promoção da saúde, tendo em vista a numerosidade desses profissionais no âmbito do cuidado.

\section{Conclusão}

O esgotamento profissional infelizmente é um problema que é comum no dia a dia dos trabalhadores de enfermagem no âmbito das Unidades de Terapia Intensiva. Essa síndrome tem impacto negativo na vida desses profissionais que vão de depressão a vícios, tendo influência direta na vida social e familiar do profissional, mesmo com consequências tão graves não se tem tantas pesquisas quanto deveriam e isso é algo alarmante.

$\mathrm{O}$ assunto do presente estudo tem grande relevância na atualidade, principalmente devido a atual situação em que o Brasil se encontra, enfrentando uma dura batalha contra a COVID 19, onde se tem UTI com superlotação, o 
profissional enfermeiro representa um importante componente dentro desse setor por lidar de forma direta com o paciente a toda hora.

É necessário que além dos pesquisadores e das empresas, os trabalhadores juntamente com os seus gestores também entendam a importância de se cuidarem psicologicamente, de minimizar de forma saudável fatores estressantes que possam existir ali no ambiente para que juntos assim possam promover a saúde dos enfermeiros que trabalham nessas unidades. 


\section{Referências}

ALVES, Michelle Cardoso et al. Prevalência de esgotamento profissional em técnicos em enfermagem de uma unidade de terapia intensiva adulto. Revista Brasileira de Enfermagem, v. 74, n. 3, p. 1-7, 2021. Disponível em: https://www.scielo.br/j/reben/a/ZYy9vW8mPmHTRfzLQRWdBZC/?lang=e n. Acesso em: 6 maio 2021.

FARIA, Sara et al. Saúde mental dos enfermeiros: contributos do burnout e engagement no trabalho. Revista Portuguesa de Enfermagem de Saúde Mental, v. 22, p. 9-18, dez. 2019. Disponível em: https://www.researchgate.net/publication/338989058_Saude_mental_dos_enf ermeiros_Contributos_do_burnout_e_engagement_no_trabalho. Acesso em: 6 maio 2021.

FERNANDES, Larissa Santi; NITSCHE, Maria José Trevizani; GODOY, Ilda de. Associação entre síndrome de burnout, uso prejudicial de álcool e tabagismo na enfermagem nas UTIs de um hospital universitário. Ciência \& Saúde Coletiva, v. 23, n. 1, p. 203-14, jan. 2018. Disponível em:

https://www.scielo.br/j/csc/a/Zgmw3RvWppqs3GNMmRZB5Bm/abstract/ ?lang=pt. Acesso em: 1 mar. 2021.

GARCIA, Gracielle Pereira Aires; MARZIALE, Maria Helena Palucci. Indicadores de esgotamento profissional em trabalhadores da atenção primária à saúde. Revista Brasileira de Enfermagem, v. 71, p. 2469-78, 2018. Suplemento 5. Disponível em:

https://www.scielo.br/j/reben/a/JykXxzMdMmnZmL8WFd8mC3s/?lang=pt \&format=pdf. Acesso em: 6 maio 2021.

LORENZ, Vera Regina; SABINO, Marcos Oliveira; CORREA FILHO, Heleno Rodrigues. Esgotamento profissional, qualidade e intenções entre enfermeiros de saúde da família. Revista Brasileira de Enfermagem, v. 71, n. 5, p. 2295-301, 2018. Disponível em:

https://www.scielo.br/j/reben/a/T5pNRQg6MC4PQQLYkc4HsmF/?lang=pt. Acesso em: 1 mar. 2021.

MENDES, Karina Dal Sasso; SILVEIRA, Renata Cristina de Campos Pereira; GALVÃO, Cristina Maria. Revisão integrativa: método de pesquisa para a incorporação de evidências na saúde e na enfermagem. Texto \& Contexto Enfermagem, v. 17, n. 4, p. 758-64, dez. 2008. Disponível em:

https://www.scielo.br/j/tce/a/XzFkq6tjWs4wHNqNjKJLkXQ/abstract/?lang =pt. Acesso em: 24 abr. 2021. 
MODESTO, João Gabriel; SOUZA, Luísa Meirelles de; RODRIGUES, Tatiana S. L. Esgotamento profissional em tempos de pandemia e suas repercussões para o trabalhador. Revista Pegada, v. 21, n. 2, p. 376-91, maio/out. 2020. Disponível em: https://revista.fct.unesp.br/index.php/pegada/article/view/7727. Acesso em: 8 maio 2021.

SCHALLENBERGER, Cláudia Denise et al. Componentes da sensibilidade moral identificados entre enfermeiros de unidades de terapia intensiva. Revista Brasileira de Enfermagem, v. 72, p. 2-8, fev. 2019. Suplemento 1. Disponível em:

https://www.scielo.br/j/reben/a/X8sGsrDZRw75bF9ZWWGj5rL/?lang=pt. Acesso em: 3 jun. 2021.

SILVA, Jorge Luiz Lima da et al. Fatores psicossociais e prevalência da síndrome de burnout entre trabalhadores de enfermagem intensivistas. Revista Brasileira de Terapia Intensiva, v. 27, n. 2, p. 125-313, abr./jun. 2015. Disponível em: https://www.scielo.br/j/rbti/a/GLk74jjG7Hvx85s63gBqnbs/abstract/?lang=p t. Acesso em: 20 maio 2021.

SILVA, Renata Souza Pereira de Melo da et al. O esgotamento do profissional enfermeiro: influências a assistência à saúde. Revista Rede de Cuidados em Saúde, v. 10, n. 1, p. 1-15, 2017. Disponível em:

http://publicacoes.unigranrio.edu.br/index.php/rcs/article/view/4082/2239. Acesso em: 8 maio 2021.

SOUSA, Luís Manuel Mota de et al. Metodologia de revisão integrativa da literatura em enfermagem. Revista Investigação em Enfermagem, v. 21, n. 2, p. 17-26, nov. 2017. Disponível em:

https://www.researchgate.net/publication/321319742_Metodologia_de_Revis ao_Integrativa_da_Literatura_em_Enfermagem. Acesso em: 6 maio 2021.

VASCONCELOS, Eduardo Motta; MARTINO, Milva Maria Figueiredo de; FRANÇA, Salomão Patrício de Souza. Burnout e sintomatologia depressiva em enfermeiros de terapia intensiva: análise de relação. Revista Brasileira de Enfermagem, v. 71, n. 1, p. 135-41, jan./fev. 2018. Disponível em:

https://www.scielo.br/j/reben/a/BbjMBP3CSmZjCzTH7YBGVfq/?lang=pt. Acesso em: 3 jun. 2021.

VASCONCELOS, Eduardo Motta de; MARTINO, Milva Maria Figueiredo de. Preditores da síndrome de burnout em enfermeiros de unidade de terapia intensiva. Revista Gaúcha de Enfermagem, v. 38, n. 4, p. 1-8, 2017. Disponível em: https://www.scielo.br/j/rgenf/a/GXynyHkjtqZvv9rdb74w8by/?lang=pt. Acesso em: 24 abr. 2021. 


\section{2}

Aleitamento materno no bebê com cardiopatia congênita: A escuta da mãe 


\title{
2 ALEITAMENTO MATERNO NO BEBÊ COM CARDIOPATIA CONGÊNITA: A ESCUTA DA MÃE
}

\author{
Joana Angélica Marques Pinheiro \\ Thereza Maria Magalhães Moreira \\ Márcia Maria Tavares Machado \\ Marilia Ximenes Freitas Frota \\ Andressa Alencar Gondim \\ Vera Lúcia Mendes de Paula Pessoa
}

\section{Resumo}

Introdução: Falar sobre saúde coletiva na atualidade é incluir um olhar interdisciplinar aprofundado no intuito de identificar determinantes, repercussões e cuidados envolvidos no processo da doença auxiliando na organização e assistência dos serviços de saúde. A cardiopatia congênita é uma condição que exige um cuidado individual especializado a acompanhar a díade desde os primeiros sinais do acometimento. Objetivo: Compreender a vivência do aleitamento materno de bebês com cardiopatia congênita e as propostas dos serviços de saúde voltados a essa condição. Método: Estudo descritivo com abordagem qualitativa, realizado por meio de entrevista semiestruturada com mães internadas com seus bebês para tratamento de cardiopatia congênita em hospital de referência. Utilizou-se a técnica de análise de conteúdo de Minayo (2012), com referencial teórico específico para embasamento da discussão. Resultados: A realidade de mães de bebês com cardiopatia perpassa por momentos de dificuldade desde o diagnóstico até as repercussões advindas da doença e das múltiplas internações e intervenções que a doença faz necessária. A inabilitação da amamentação, pelas condições clínicas do bebê, é uma delas, provocando sentimentos de culpa e ansiedade na mãe e interferindo na vinculação com o filho. Conclusão: $O$ impacto emocional pela internação e inviabilização de cuidados como a amamentação exige uma equipe de saúde especializada para oferecer suporte afetivo, fortalecer o vínculo mãe-bebê e minimizar prejuízos ao desenvolvimento neuropsicomotor que esse bebê possa apresentar proveniente da falta de contato materno, do quadro clínico ou do próprio internamento necessitando muitas vezes da continuidade de atendimentos especializados impactando nos serviços de saúde.

Palavras chaves: Aleitamento Materno. Cardiopatia. Relações Mãe-Filho. 


\section{Introdução}

Pensar na saúde coletiva na atualidade inclui um olhar interdisciplinar aprofundado que perpasse pela saúde e ciência social de maneira a identificar os determinantes, repercussões e cuidados envolvidos no processo da doença auxiliando na organização e assistência dos serviços de saúde.

$\mathrm{O}$ aprofundamento de estudos em áreas específicas de cuidado a saúde, reforça políticas públicas, gestores e profissionais da saúde a direcionar conhecimento e ações aos problemas relacionados a saúde de um público específico e junto a saúde da população em geral, no intuito de promover melhor qualidade de vida.

A proposta desse estudo é esclarecer a realidade do público na condição da cardiopatia congênita vivenciada no sistema de saúde e unidade de internamento. Trata-se de uma anormalidade na estrutura ou função cardiocirculatória que pode ser diagnosticada no período pré-natal, na infância, adolescência ou até mesmo na idade adulta (PINTO JÚNIOR et al., 2015). As cardiopatias podem apresentar sintomatologia variável, necessitando de acompanhamento médico e na maioria das vezes de intervenções cirúrgicas.

Os sinais clínicos mais característicos das cardiopatias congênitas são sopro cardíaco, cianose, taquipneia, baixo débito sistêmico e nas mais graves, frequência respiratória maior que 60 incursões respiratórias por minuto (IRPM) em repouso e saturação periférica menor que 90\% aferida após 24 horas de vida (BRASIL, 2011).

A doença cardíaca na infância pode acarretar uma série de alterações como, por exemplo, desnutrição e défice de crescimento, justificadas pelo estado hipermetabólico, pela inadequada ingestão calórica, pelas dificuldades de deglutição, pela má absorção de alimentos, pelo refluxo gastroesofágico, pela imaturidade do trato gastrointestinal, além dos fatores genéticos associados e presentes nessa criança (MEDOFF-COOPER; RAVISHANKAR, 2013). Tais condições podem repercutir no sistema de saúde tendo em vista que envolve 
maior vulnerabilidade para doenças em geral além de múltiplas internações para acompanhamento e realização de cirurgias.

O ganho ponderal de um bebê com cardiopatia é prejudicado muitas vezes pela questão respiratória, pois as dificuldades em se manter um padrão de respiração estável e, coordenadas são tão significativas, que interferem na amamentação e/ou a alimentação por via oral, ocasionando o uso precoce de fórmulas, com incremento de calorias, por meio de mamadeira ou vias alternativas de alimentação (sondas). Atualmente, com relação ao aleitamento materno do bebê com cardiopatia, existem novas perspectivas que enfatizam a capacidade dessas mães de iniciarem e manterem com êxito a lactação, assim como ocorre as mães de lactentes saudáveis que são incentivadas por todos os equipamentos de saúde em fazê-lo no pré-natal (TOROWICZ et al., 2015).

A necessidade de permanência do filho em Unidades de Terapia Intensiva (UTI) ou com uso de suportes tecnológicos acaba interrompendo o cuidado materno, o que pode interferir no desenvolvimento e nas experiências vivenciadas entre mãe e filho, em especial, a amamentação. Muitas vezes, a interrupção da amamentação é necessária pela condição clínica do bebê ou pela necessidade de intervenções para tratamento, o que agrava a já sofrida situação emocional materna. Em tal momento um apoio profissional com o olhar para a saúde de forma ampliada se faz indispensável para a díade que tende a retornar após resolutividade do caso.

As políticas para assistência ao paciente com cardiopatia vêm se modificando ao longo dos anos e, atualmente, há maior incentivo à alimentação oral dos pacientes cardíacos neonatais em estado crítico, assim também como maior cuidado para alimentar antes da cirurgia, e o mais cedo possível após cirurgia. Tal concepção alcança também procedimentos como extubação precoce e desmame o mais breve possível de suporte ventilatório (SABLES-BAUS et al., 2012). Exigindo para isso uma equipe especializada para avaliar as condições clínicas do bebê e restabelecer a dieta por via oral, inclusive do aleitamento materno, fortalecendo também a aproximação, vinculação e envolvimento da mãe no cuidado geral do bebê (CZECHOWSKI; FUJINAGA, 2010). 
Apesar da maioria dos serviços de saúde e das unidades hospitalares do país seguirem os preceitos e normas da Política Nacional de Humanização, ainda são comuns situações em que a família tem uma participação limitada na assistência, evidenciadas por regras hospitalares restritivas, podendo ocasionar, no caso das mães de bebês internados, uma experiência traumática e dolorosa com sentimentos de angústia, culpa, punição e medo da morte, emoções que podem interferir diretamente na vinculação e na produção de leite materno (PAIVA et al., 2013). Tais condições maternas, embasadas em literatura pertinente, justificaram essa pesquisa.

\section{Objetivo}

Compreender a vivência do aleitamento materno de bebês com cardiopatia congênita e as propostas dos serviços de saúde voltados a essa condição.

\section{Método}

Trata-se de uma pesquisa descritiva com abordagem qualitativa, realizada na unidade de cardiopediatria de um Hospital referência em cardiologia pediátrica na cidade de Fortaleza, em um centro de referência Norte-Nordeste do Brasil no tratamento de cardiopatia congênita e transplante cardíaco pediátrico.

Foram incluídas no estudo as mães que se encontravam internadas com seus filhos na unidade de cardiopediatria, com idade superior a 18 anos e excluídas mães de bebês com comorbidade associada a cardiopatia congênita. No decorrer da realização das entrevistas, por não surgirem elementos novos, acabou-se definindo um total de nove mães com falas representativas sobre a temática proposta. Essas mães foram previamente esclarecidas sobre a pesquisa, o sigilo e anonimato, com assinatura do Termo de Consentimento Livre e Esclarecido. 
As informações foram coletadas com as mães a partir de entrevistas individuais semiestruturadas e gravadas, na enfermaria da Unidade de Cardiopediatria. Após entrevistas, os discursos maternos foram transcritos na íntegra e identificados por M1, M2, .., M9, assegurando assim o anonimato às mães. Concluída essa fase, seguiram-se as etapas de análise de conteúdo propostas por Minayo (2012), com delineamento das informações e definição de categorias, que levaram ao embasamento do presente estudo.

Este estudo integra uma pesquisa maior intitulada: Aleitamento materno no bebê com cardiopatia, que obteve a aprovação do Comitê de Ética em Pesquisa do Hospital Dr. Carlos Alberto Studart Gomes sob o Parecer n 1.285.784.

\section{Resultados e Discussão}

\section{Conhecendo as mães entrevistadas}

A abordagem ocorreu com as mães que estavam com seus bebês internados na enfermaria através de conversa informal com a mãe a respeito de dados gerais sobre ela e o filho, o que permitiu caracterizar o público em estudo. Este contato possibilitou um momento de verbalização espontânea, descontraída, sendo possível observar condições físicas e emocionais das mães para participarem efetivamente do estudo.

Em relação às participantes do estudo, três mães eram adolescentes e seis já adultas, com intervalo de idade variando entre 18 a 30 anos. Dessas, cinco se definiram como casadas e quatro se disseram solteiras, apesar de, estas últimas, relatarem ainda manter relacionamento com o pai do bebê. Apenas duas possuíam o Ensino Superior Completo, três haviam concluído o Ensino Médio e quatro delas tinham o Ensino Médio incompleto. Apenas uma adolescente referiu ainda estar estudando. Seis mães eram do interior do estado e três residiam na capital. Todas relataram ter feito o pré-natal completo. 
O tempo de internação, no momento do estudo, segundo relato das mães variou de um dia a um mês e quinze dias de internamento. Das nove mães participantes do estudo, sete aguardavam o procedimento cirúrgico dos filhos e apenas duas encontravam-se na enfermaria acompanhando-os no pós-cirúrgico.

A média de idade dos bebês das mães participantes variou de um mês de vida há um ano e quatro meses. Em relação ao diagnóstico, quatro pacientes apresentaram diagnóstico de Comunicação Interventricular (CIV), três de Transposição de Grandes Artérias (TGA), um Tetralogia de Fallow (T4F) e um caso de estenose aórtica. Com relação à experiência e tempo de aleitamento materno, os períodos variaram de um dia a um ano e quatro meses na prática. Quatro dos bebês estavam utilizando vias alternativas de alimentação com fórmula infantil, sendo três por sonda orogástrica e 1 por sonda nasogástrica. Cinco bebês estavam alimentando-se por via oral total, sendo quatro por aleitamento materno com complementação e apenas um por aleitamento materno exclusivo.

Durante as entrevistas as mães mostraram-se disponíveis e emocionadas em falar sobre o filho, a doença e sua vivência particular na amamentação, algumas porque se sentiam satisfeitas e alegres por terem conseguido êxito em amamentar, outras, porém, pareciam frustradas por isso não ter sido possível. No entanto, todas se mostraram conscientes e conhecedoras do uso e benefício do leite materno, aprendidos durante realização do pré-natal na atenção básica.

A escuta materna sobre a vivência no aleitamento do seu bebê com cardiopatia congênita

A maternidade é um momento de inúmeras mudanças físicas e emocionais na vida da mulher. No âmbito psicológico, configura-se como um período de transformações e que se estende para além da gravidez, alcançando o parto, o puerpério e a própria relação que vai sendo estabelecida entre mãe e bebê definindo para essa mulher um novo papel que vem evoluindo e deixando de ser meramente voltado ao cuidado básico de sobrevivência do bebê, atingindo um 
significado maior de envolvimento emocional e afetivo (GRADVOHL; OSIS; MAKUCH, 2014).

É a partir da gestação que a mulher passa a planejar e idealizar o filho, desde aspectos físicos e emocionais a relação a ser vivenciada entre eles após o parto, inclusive a amamentação. Nos casos de bebês com cardiopatia congênita a mãe acaba se deparando com um filho com deficiência ou necessidade especial cujo diagnóstico pode ter ocorrido em diferentes momentos: no pré-natal, imediatamente após o parto ou até mesmo em idades mais avançadas, necessitando de um olhar mais específico da equipe de saúde.

Assim, se pensarmos no aleitamento materno do bebê com cardiopatia, é comum encontrarmos casos em que a amamentação é possível, mas, em outros, não. De acordo com a alteração cardíaca apresentada, a possibilidade ou não de amamentação funciona, muitas vezes, como sinal clínico, antecipando o diagnóstico para a equipe médica e, até mesmo, para a mãe, pois percebem que algo não vai bem.

Existe uma recomendação da Organização Mundial de Saúde (OMS) e do Fundo das Nações Unidas para a Infância (UNICEF) de se colocar os recémnascidos imediatamente em contato com a mãe logo após o parto, no intuito de se fortalecer o contato mãe-filho (pele a pele), pela amamentação ainda na sala de parto. Essa estratégia é seguida por algumas instituições e confirmada pela fala de algumas mães entrevistadas:

\footnotetext{
Ela permaneceu junto comigo do nascimento até a alta [...] e foi logo para o peito (M6).

[...] assim que ele nasceu trouxeram logo para amamentar ele [...] (M9).
}

Essa experiência do aleitamento materno nas primeiras horas após o parto reforça a confiança da mãe em relação à capacidade de amamentar e auxilia também no vínculo mãe/filho. Essa aproximação ocorre no momento da amamentação, pela comunicação silenciosa entre a mãe e o bebê, pelos gestos, sorrisos e vocalizações entre eles (WINICOTT, 2013). Essa ligação proporcionada 
pela amamentação é facilmente identificada pela mãe, como podemos observar em alguns relatos:

$[\ldots]$ parece que a gente fica mais próxima dele [...] (M1).

$[\ldots]$ a troca minha com ele e dele comigo [...] M2.

[...] faz aquele laço entre a mãe e o filho [...] (M8).

Observa-se que a amamentação passa a ter outro significado que não só o de mera sobrevivência, mas também o de alcançar o afeto e a troca entre mãe e filho. Esse novo modo de ver o aleitamento materno desperta na mulher um reforço à prática de amamentação, não só pelos benefícios previamente orientados no pré-natal, mas também pela sensação de bem-estar. Algumas mães, motivadas pela forma como se sentem em relação ao bebê, desde a gestação, atribuem um significado para o aleitamento materno; um significado de ato de amor.

[...] é como (se) o leite é o meu sangue... é como se eu tivesse dando meu sangue pra vida dela [...] (M6).

[...] pra mim é um gesto de amor [...] (M1).

Essa concepção das mulheres sobre a amamentação vai sendo construída desde o pré-natal e se modificando com a prática, seja ela positiva ou não. A manutenção do aleitamento materno é mais frequente nessas mães que se mostram encantadas com o ato de amamentar e que conhecem os benefícios do leite materno para seus filhos, com destaque também para aquelas cujo apoio familiar se faz presente (WINNICOTT, 2013). Muito desse conhecimento materno apreendido foi revelado nas falas como identificamos a seguir:

[...] o meu(leite) tem mais coisas que iriam fazer ele crescer melhor, mais inteligente, mais forte [...] (M1).

Sei que faz muito bem pra ela[...]ajuda no crescimento dela [...] fortalece ela (M7).

O leite materno é melhor do que qualquer leite [...] (M9). 
É possível observar que as mães foram previamente orientadas sobre o aleitamento materno, reconhecendo os benefícios que o leite materno pode proporcionar. Esse aconselhamento prévio mostra-se essencial para incentivar as mães a amamentar seus filhos, isso porque a inexperiência materna e a falta de informação podem levar ao desmame precoce, pelo despreparo em enfrentar dificuldades que possam surgir no processo (SCHEEREN et al., 2013). Tal constatação reforça a importância de programas na saúde coletiva voltados a incentivar e empoderar as mulheres à prática favorecendo a díade e sua rede de apoio familiar.

O esclarecimento que algumas mães apresentam provenientes do contato com o profissional de saúde, se mostra indispensável no momento da amamentação, seja ao realizar orientações e intervenções que se façam necessárias, ou apoiando a mãe e a família (CASTELLI; MAAHS; ALMEIDA, 2014). Tais ações foram identificadas em alguns relatos:

[...] meu marido incentivou e a psicóloga também falou comigo [...] aí eu fiquei mais calma [...] (M1).

Eu dava mama porque de tanto os médicos dizerem que é bom, que é bom, que é bom [...] a gente "bota" aquilo na cabeça que fica até com medo (M4).

Constata-se, assim, que os profissionais, da atenção básica à terciária, precisam ser sensíveis à causa do aleitamento materno e capazes de compreender e identificar quais dimensões possam dificultar a amamentação, para que consigam atuar diretamente, de modo empático, na especificidade de cada uma das dificuldades apresentadas, priorizando o bem-estar geral da mãe e do bebê para além daquela situação também (MARQUES; PEREIRA, 2010).

A mãe precisa estar apta, física e emocionalmente para oferecer a mama e o bebê precisa ter condições de sugar, deglutir e respirar com coordenação adequada, sem riscos de complicações à saúde, já tão fragilizada (AZEVEDO, 2011). No caso de bebês com cardiopatia congênita, a sintomatologia, independente do diagnóstico definitivo, pode interferir de forma 
significativa ou não, no processo de amamentação, como podemos ver nos relatos a seguir:

[...] quando ele mamava ele ficava cansado [...] (M5).

O primeiro momento da amamentação foi um pouco complicado pela minha condição logo após o parto normal[...]condições físicas mesmo [...] (M6).

[...] não mamou bem nos primeiros momentos, ele não sabia, né? Ele estava tentando [...] mas depois do primeiro dia ele pegou muito bem $[\ldots]$ até hoje $[\ldots]$ (M8).

Ele mamou [...] aí depois que ele mamou [...] ele estava muito roxo e cansado [...] (M9).

Nas falas, além dos casos em que a sintomatologia da cardiopatia interferiu ou impediu a amamentação, houve destaque também para a mãe, com relação às condições no pós-parto, à dificuldade de levar o bebê ao seio, assim como em relação aos aspectos emocionais vivenciados no momento. Apesar disso não se definira capacidade do bebê em mamar nem na duração da amamentação ao seio materno. Faz-se necessária uma observação criteriosa do quadro clínico do paciente, por uma equipe especializada para definir a intervenção ideal para cada caso (SANTIAGO, 2013).

A literatura destaca que mães de crianças com cardiopatia são capazes de desenvolver, manter a lactação e alcançar um volume de leite materno ideal para o seu bebê (TOROWICZ et al., 2015). Para isso, é importante que a equipe acompanhe a díade, no intuito de verificar se a oferta de leite materno, durante a internação, está dentro do esperado para que nos casos em que haja necessidade, possa intervir conforme orientação do MS.

Conforme o grau de complexidade da cardiopatia, a utilização de vias alternativas de alimentação pode se mostrar indispensáveis para alguns bebês, pois estes podem apresentar alterações significativas no padrão respiratório, sucção, deglutição, desnutrição e défices no crescimento, desencadeando essa conduta que visa, prioritariamente, à sobrevivência do bebê. 
Assim, as sondas de alimentação são utilizadas, por mostrarem-se essenciais não apenas ao aspecto nutricional em si, mas também para a administração de medicamentos nos casos de inabilitação completa da via oral (GORZONI; TORRES; PIRES, 2010).

Ser impedida de amamentar e ver o filho fazendo uso de sonda de alimentação coloca essa mãe diante de uma realidade totalmente inesperada, em que o filho passa a alimentar-se por meio de um mecanismo alheio a ela e que não provém dela, ou seja, do seu seio ou seu próprio leite. Essa experiência gera, na mãe, sofrimento, angústia, tristeza e até culpa, especialmente naquelas que consideram a amamentação inerente ao papel de mãe:

Eu fiquei assim meio abalada com a colocação da sonda [...] (M1).

[...] parar de amamentar foi como se estivessem me separando da minha filha [...] (M6).

Eu chorei [...] porque eu não sabia nem o que era e vi meu filho com aquela coisa na boca [...] comendo por aquilo [...] (M9).

Esses sentimentos passam, então, a fazer parte do cotidiano dessa mãe e alcançam o significado de distanciamento para algumas delas. A palavra separação mencionada vai além da condição física e diz respeito ao papel perdido de mãe, desencadeando sentimentos de inferioridade, pois não se sentem úteis no plano de tratamento e na vida do filho.

Mesmo reconhecendo e aceitando todo o contexto em que seu bebê se encontra inserido, com todo aparato tecnológico e com a necessidade de uma equipe especializada como suporte, observa-se a valorização das mães em relação ao leite materno e o desejo de que fosse utilizado seu próprio leite para o filho.

[...] o leite materno tem mais coisas do que com o leite artificial, industrializado [...] (M1).

[...] pra mim o maior problema não é nem ele estar de sonda é ele não estar podendo tomar o meu leite [...] (M2). 
[...] mesmo que eu não pudesse dar de mamar, eu ficava alegre porque ia "tá" dando o meu leite para o meu filho [...] (M5).

A constatação dos benefícios relativos ao leite materno faz com que muitas mães se esforcem para conservar a produção de leite mesmo durante o internamento e o uso de sondas de alimentação por seus bebês. Para tanto, a mãe procura seguir as orientações dos profissionais, mantendo a ordenha mesmo com os desconfortos provenientes do período de hospitalização, empenhadas em conseguir um fluxo de leite materno suficiente para o bebê, na expectativa de que, consiga a liberação médica e da equipe, para seu bebê retomar a via oral e à amamentação.

Sabe-se que, mesmo com o empenho e a disponibilidade materna, a própria hospitalização pode interferir na lactação, seja pela questão do ambiente hospitalar ou por questões físicas dessa mãe, que necessita manter boa alimentação, ordenha regular e estado emocional minimamente estável, para conseguir uma produção de leite suficiente para atender à demanda do seu bebê.

No caso de bebês com cardiopatia, a cirurgia cardíaca em si já se apresenta como algo estressante para a mãe e para o bebê, considerando envolver alguns processos e intervenções necessidade de permanecer em UTI, entre vários outros aspectos que contribuem para o agravamento da ansiedade materna, sem deixar de mencionar o risco de morte do filho, principal preocupação da mãe. Além disso alguns bebês podem apresentar problemas no pós-operatório, como dificuldade para alimentar-se e retardo no desenvolvimento motor e neurológico o que exige a presença de equipe especializada no intuito de minimizar sequela e prestar assistência e suporte à díade (SOLBERG et al., 2012). A atuação profissional na amamentação e a satisfação em vivenciar esse momento podem ser identificadas no discurso de algumas mães:

Foi estimulado pela "fono", a equipe toda me ajudou e saiu mamando [...] (M2).

Me ajudaram muito... me senti ótima quando voltou a mamar [...] (M3). 
Cabe, pois, ao profissional, promover o cuidado geral do bebê, buscando estabilidade clínica e sobrevivência, ofertar todas as possibilidades de uma vida melhor dentro do que se espera para a fase pré e pós-operatória, além de propiciar a possibilidade do AM, respeitando as características e necessidades individuais de cada um. A assistência deve abranger também a mãe, de forma mais humanizada, priorizando a escuta e o diálogo, no intuito de minimizar a ansiedade, o estresse e os comportamentos não adaptáveis do período de internação.

\section{Conclusão}

Com os discursos das mães, fica evidente o entendimento que elas têm sobre as razões e restrições quanto à colocação do filho ao seio e aos riscos para o agravamento do quadro quando o bebê é inabilitado pela equipe médica mesmo tendo sido previamente orientadas sobre o AM no pré-natal. Essa impossibilidade de amamentar ou de ter seu próprio leite sendo ofertado ao filho, com a prevalência de utilização de fórmulas infantis, foi o que pareceu desencadear maior insatisfação e estresse materno.

Situações vivenciadas como essas podem alterar o estado emocional materno, interferir diretamente na lactação e no estabelecimento do vínculo mãe/filho, podendo afetar o bem-estar físico e emocional da mãe, além de se mostrar como risco de provocar alterações no desenvolvimento cognitivo e emocional do bebê.

Os profissionais de saúde envolvidos devem ampliar o olhar para além das condições físicas e clínicas da díade, e voltar-se para um acolhimento e orientação dessa mãe, na busca de uma estrutura para ordenha e o uso do leite materno para o bebê, atentos também ao envolvimento emocional dessa mulher nesse período.

Tratando-se de bebês com cardiopatia, a equipe deve estar preparada para oferecer suporte no momento em que a mãe recebe liberação médica para 
ter seu bebê alimentado, seja ao seio materno ou por outro meio que se faça necessário e quando definido pelos profissionais. Cabe à equipe especializada oferecer maior segurança na utilização do copo, da mamadeira ou da sonda, mas sempre empenhada em estimular o contato, a afetividade, o vínculo e o amor incondicional que une mãe e filho.

Apesar do número restrito de material científico e de recursos terapêuticos voltados ao aleitamento materno no bebê com cardiopatia congênita como existe para a população geral esse estudo teve o intuito de incentivar um olhar ampliado para o conhecimento científico, profissional e pessoal dos profissionais da saúde, estimulando condutas mais humanizadas e acolhedoras, voltadas a proporcionar bem-estar físico e emocional para mãe e bebê durante o internamento, tendo em vista que fazem parte de um todo dentro da saúde coletiva. 


\title{
Referências
}

\author{
AZEVEDO, M. Padrões de aleitamento materno em recém-nascidos pré-termo \\ internados e no primeiro mês após a alta hospitalar. 2011. 93 f. Dissertação \\ (Mestrado em Enfermagem) - Universidade Federal do Rio Grande do Sul, \\ Porto Alegre, 2011. Disponível em: \\ http://bdtd.ibict.br/vufind/Record/URGS_ddfc7108aea6b5fa16ff5f0848814a7d \\ . Acesso em: 12 abr. 2021.
}

BRASIL. Ministério da Saúde. Secretaria de Atenção à Saúde. Atenção à saúde do recém-nascido: guia para os profissionais de saúde. Brasília, DF: Ministério da Saúde, 2011. Disponível em:

https://bvsms.saude.gov.br/bvs/publicacoes/atencao_saude_recem_nascido_ v1.pdf. Acesso em: 25 set. 2020.

CASTELLI, Carla Thamires Rodriguez; MAAHS, Marcia Angelica Peter; ALMEIDA, Sheila Tamanini de. Aleitamento materno: dúvidas e dificuldades. Revista CEFAC, v. 16, n. 4, p. 1178-1184, jul./ago. 2014. Disponível em: https://www.scielo.br/j/rcefac/a/qJTpWtZKNLwFmqPW9YYdLkq/?format= pdf\&lang=pt\#: :text=Quando $\% 20$ questionadas $\% 20$ sobre $\% 20$ fatores $\% 20 q u e$,leit e\%3B\%20estar\%20com\%20dor\%20nas. Acesso em: 22 nov. 2020.

CZECHOWSKI, Aliana Eduarda; FUJINAGA, Cristina Ide. Seguimento ambulatorial de um grupo de prematuros e a prevalência do aleitamento na alta hospitalar e ao sexto mês de vida: contribuições da fonoaudiologia. Revista da Sociedade Brasileira de Fonoaudiologia, v. 15, n. 4, p. 572-7, dez. 2010. Disponível em:

https://www.scielo.br/j/rsbf/a/XztW73LscrZCtySbJwDKwTz/abstract/?lang =pt. Acesso em: 22 nov. 2020.

GORZONI, Milton Luiz; TORRE, Anderson Della; PIRES, Sueli Luciano. Medicamentos e sondas de nutrição. Revista da Associação Médica Brasileira, v. 56, n. 1, p. 17-21, 2010. Disponível em: https://www.scielo.br/j/ramb/a/4yLq9zCJKqcQyB3HF6P9P9m/abstract/?la ng=pt. Acesso em: 12 abr. 2021.

GRADVOHL, Silvia Mayumi Obana; OSIS, Maria José Duarte; MAKUCH, Maria Yolanda. Maternidade e formas de maternagem desde a idade média à atualidade. Pensando Famílias, v. 18, n. 1, p. 55-62, jun. 2014. Disponível em: http:// pepsic.bvsalud.org/scielo.php?script=sci_arttext\&pid=S1679_ 494X2014000100006. Acesso em: 22 nov. 2020. 
MARQUES, Danielle Moreira; PEREIRA, Adriana Lemos. Amamentar: sempre benefícios, nem sempre prazer. Revista Ciência Cuidado e Saúde, v. 9, n. 2, p. 214-219, 2010. Disponível em:

https://periodicos.uem.br/ojs/index.php/CiencCuidSaude/article/view/896 3. Acesso em: 12 abr. 2021.

MEDOFF-COOPER, Barbara; RAVISHANKAR, Chitra. Nutrition and growth in congenital heart disease: a challenge in children. Current Opinion Cardiology, v. 28, n. 2, p. 122-129, 2013.

MINAYO, Maria Cecília de Sousa. Qualitative analysis: theory, steps and reliability. Ciência \& Saúde Coletiva, v. 17, n. 3, p. 621-626, Mar. 2012.

Disponível em:

https://www.scielo.br/j/csc/a/39YW8sMQhNzG5NmpGBtNMFf/?lang=en.

Acesso em: 22 nov. 2020.

PINTO JÚNIOR, Valdester Cavalcante et al. Epidemiology of congenital heart disease in Brazil. Brazilian Journal of Cardiovascular Surgery, v. 30, n. 2, p. 219-224, 2015. Disponível em:

https://www.scielo.br/j/rbccv/a/9wWc6p7Wf3YGwbK4xkQJkHS/?lang=en. Acesso em: 29 set. 2020.

SABLES-BAUS, Sharon et al. Oral feeding outcomes in neonates with congenital cardiac disease undergoing cardiac. Cardiology in the Young, v. 22, n. 1, p. $42-$ 48, Feb. 2012.

SANTIAGO, Luciana Borges. Manual de aleitamento materno. São Paulo: Manole, 2013.

SCHEEREN, Betina et al. Condições iniciais no aleitamento materno de recém-nascidos prematuros. Jornal da Sociedade Brasileira de Fonoaudiologia, v. 24, n. 3, p. 199-204, 2013. Disponível em: https://www.scielo.br/j/jsbf/a/rNF59CqXsktRFfky3gbzjZP/?lang=pt. Acesso em: 22 nov. 2020.

SOLBERG, Øivind et al. Trajectories of maternal mental health: a prospective study of mothers of infants with congenital heart defects from pregnancy to 36 months postpartum. Journal of Pediatrics Psychology, v. 37, n. 6, p. 687-696, July 2012. Disponível em:

https://www.ncbi.nlm.nih.gov/pmc/articles/PMC3381713/. Acesso em: 12 abr. 2021. 
TOROWICZ, Deborah L. et al. Human milk and breastfeeding outcomes in infants with congenital heart disease. Breastfeeding Medicine, v. 10, n. 1, p. 3137, Jan. 2015.

WINNICOTT, Donald Winnicott. Os bebês e suas mães. 4. ed. São Paulo: Martins Fontes, 2013. 


\section{3}

Risco de quedas em idosos

o o papel da família: Uma

revisão integrativa 


\title{
3 RISCO DE QUEDAS EM IDOSOS E O PAPEL DA FAMÍLIA: UMA REVISÃO INTEGRATIVA
}

\author{
Levi Paulo da Costa \\ Ivana Cristina Vieira de Lima Maia
}

\section{Resumo}

Introdução: A exposição a quedas é bastante comum entre idosos, pois estes apresentam características multifatoriais associados à redução do cálcio, responsável pelo fortalecimento dos ossos, redução na produção de hormônios e osteoporose. Objetivo: Investigar as evidências da literatura sobre o risco de quedas em idosos e o papel da família. Metodologia: Trata-se de uma revisão integrativa na qual foi realizada busca avançada nos sites da Biblioteca Virtual em Saúde do Ministério da Saúde (BVS), SciELO e Google Acadêmico. Foram incluídos artigos sobre a temática independentemente do idioma, publicados de 2010 a 2021. Resultados: Os estudos abordaram medidas e orientações de segurança, a fim de prevenir o risco de quedas em pessoas idosas. Ressaltou-se o papel da família nos cuidados com o idoso. Quanto aos fatores de risco para quedas, evidenciou-se que as quedas entre as mulheres geram maiores impactos como fraturas comprometimento do seu papel no lar. Conclusão: Os cuidados e a prevenção da família são os meios de evitar que o idoso caia e sofra com as sequelas que podem se estender ao longo da vida. Assim, prevenir as quedas é demonstrar o amor pelo idoso que tanto contribui direta ou indiretamente com os avanços da civilização.

Palavras-chave: Acidentes por Quedas. Idoso. Prevenção. Família. 


\section{Introdução}

O envelhecimento se manifesta ao longo do tempo, quando o ser humano passa por fases na vida, o qual os aspectos físicos, psicológicos e funcionais apresentam mudanças na sua capacidade de se locomover, na atuação em diversas funções e na sua estabilidade em determinadas situações. Quanto às situações presentes na velhice, destacam-se as alterações fisiológicas que afetam o sistema nervoso, os órgãos, a estrutura óssea e as articulações responsáveis por quedas dos idosos que resultam em escoriações e lesões, ou fraturas no fêmur e membros superiores e inferiores (AMORIM et al., 2021).

É fundamental, o aprofundamento da literatura, dando ênfase às quedas em idosos, a fim de discutir sobre as alterações fisiológicas, dados epidemiológicos os impactos à saúde e à prevenção, para evitar fraturas que podem ocasionar danos irreversíveis, ou os óbitos dos idosos. Segundo Santos (2020), o tema de envelhecimento populacional, por si só, é bastante amplo, de forma que inúmeros aspectos necessitam ser considerados antes de uma discussão acerca do tema a ser estabelecido. Embora alguns conceitos sejam praticamente absolutos, algumas opiniões podem ser relativas, já que o contexto no qual cada grupo populacional está inserido também pode ser diferente. $\mathrm{O}$ envelhecimento populacional de pessoas que possuem boas condições econômicas e de saúde, por exemplo, provavelmente será diferente de quem se encontra em uma situação oposta.

Diante dos processos de mudança na vida do idoso, a família deve estar presente para acompanhá-lo, dando o suporte necessário para que ele tenha uma vida saudável e sem riscos. De acordo com Rodrigues (2019), a fase da vida descrita como processo de envelhecimento apresenta diversas singularidades, tendo a ser distinguida pelas interações estabelecidas entre os processos cronológicos, biológicos, psicológicos e sociais. Todos esses processos se instituem conforme às condições históricas, políticas, econômicas e culturais nas quais o sujeito esteja inserido. 
Os cuidados familiares com o idoso são favoráveis para que ele tenha uma velhice mais confortável diante dos fatores que podem ocasionar inúmeros prejuízos à sua saúde, dentre eles estão: a exposição às lesões, ou fraturas nos membros superiores e inferiores, ou no fêmur. Rodrigues (2019) destaca que o suporte familiar na vida do idoso, durante o processo de envelhecimento, contribui de forma significativa diante de suas fragilidades físicas e psicológicas. O meio familiar pode definir o comportamento e as particularidades do idoso, assim em família com estilo de vida saudável e harmoniosa entre todos, incluindo o idoso, desencadeia a melhoria da qualidade de vida e das atividades diárias no meio familiar, mantendo uma relação de respeito, sem exclusão ou frustrações, de modo que o idoso evite um isolamento familiar e social.

A presença da família pode reduzir sua internação em hospital por doenças acometidas na velhice ou em clínicas de reabilitação, quando há necessidade de recuperar o idoso de fraturas que o impossibilitam sua locomoção. Segundo Carvalho (2010), diante deste cenário, o idoso fica mais susceptível a vivenciar o processo de hospitalização, expondo-se ainda mais a situações de risco, dentre elas destacam-se as quedas. Desse modo, evidencia-se a importância de desenvolver ações relacionadas à segurança do paciente, visando a proteção e a prevenção de quedas no idoso.

Neste período de pandemia, o cuidado com o idoso deve ser redobrado, a fim de evitar que ele sofra qualquer tipo de lesão ou fratura, prevenindo o internamento para processo cirúrgico ou tratamento. De acordo com Santos (2020), as quedas em idosos estão ligadas às doenças crônicas, não apenas a doenças específicas da parte neuromuscular, mas doenças sistêmicas em geral, tais como insuficiência cardíaca e infecções. Por isso, é muito importante ter um olhar especial, pois muitas vezes a queda é a única manifestação de alguma descompensação aguda.

O número de óbitos direcionados à terceira idade, chama a atenção devido aos danos permanentes, indicando a necessidade de acompanhamento para evitar novas lesões. Segundo Santos (2021), em 2017, um total de 12 mil pessoas com mais de 60 anos morreram em decorrência de quedas. Além disso, 
estimativas apontam que, por ano, no Brasil, cerca de $30 \%$ dos idosos caem pelo menos uma vez, dos quais 50\% ficam com a mobilidade reduzida, gerando lesões que vão requerer vigilância contínua para este idoso.

Para minimizar os impactos negativos quanto aos acidentes ocasionados por queda na velhice, é necessário que a família adote medidas preventivas que facilitem a locomoção do idoso no ambiente interno e externo. De acordo com Secretaria de Estado da Saúde, a prevenção das quedas é um desafio ao envelhecimento populacional (SÃO PAULO, 2010). O número de quedas aumenta em magnitude, à medida que o número de adultos mais velhos cresce, em muitas nações do mundo. As quedas aumentam exponencialmente com as mudanças biológicas associadas à idade, portanto um significativo número de pessoas com mais de 80 anos deverá desencadear um aumento substancial de quedas e dos ferimentos a elas relacionados, em níveis alarmantes. De fato, a incidência de algumas lesões relacionadas às quedas, tais como fraturas e lesões na medula, aumentaram marcantemente até a ordem de 131\% durante as últimas três décadas. Caso não sejam tomadas medidas preventivas no futuro imediato, o número de lesões causadas por quedas é projetado para ser 100\% mais alto no ano de 2030.

Neste cenário crescente da população idosa e dos riscos pertinentes de queda nesta fase, a presente pesquisa busca responder a seguinte questão: Qual o papel da família e quais os tipos de prevenção para garantir a segurança do idoso, evitando que ele seja acometido pelo risco de queda?

Justifica-se que a família tem um papel fundamental para garantir a integridade do idoso quando ele apresenta sinais de instabilidade em sua locomoção em locais de difícil acesso, a fim de evitar lesões ou fraturas que podem ser consideradas de riscos temporário e permanente, ou dependendo da gravidade pode levar a óbito. A prevenção é fundamental para evitar a queda, uma vez que os dados apontam o índice crescente da população idosa no mundo. 


\section{Objetivo}

Investigar as evidências da literatura sobre o risco de quedas em idosos e o papel da família.

\section{Metodologia}

Realizou-se uma revisão integrativa a partir de uma busca avançada nos sites da Biblioteca Virtual em Saúde do Ministério da Saúde (BVS), SciELO e Google Acadêmico. A partir do uso de descritores controlados, foram selecionados artigos publicados entre 2010 e 2021, disponíveis na íntegra, independentemente do idioma, que abordassem os riscos de queda na velhice, com avaliação do papel da família para proteger o idoso e prevenir esse agravo.

Para a seleção dos artigos, houve análise minuciosa dos títulos e resumos dos artigos, havendo posterior leitura dos artigos na íntegra. A Tabela 1 apresenta o número de estudos científicos e revistas disponíveis na BVS, SciELO e Google Acadêmico. Foram encontrados 36 estudos, pré-selecionados 26, excluídos 17 e apenas 9 foram selecionados.

Tabela 1 - Artigos selecionados nos sites BVS, SciELO e Google Acadêmico no período entre 2010 e 2021

\begin{tabular}{c|c|c|c|c}
\hline \multirow{2}{*}{ Base de dados } & \multicolumn{4}{|c}{ Número de artigos } \\
\cline { 2 - 5 } & Encontrados & Pré-selecionados & Excluídos & Incluídos \\
\hline BVS & 5 & 3 & 1 & 0 \\
SciELO & 8 & 5 & 4 & 4 \\
Google Acadêmico & 23 & 18 & 12 & 5 \\
\hline TOTAL & 36 & 26 & 17 & 9 \\
\hline
\end{tabular}

Fonte: Elaboração dos autores.

Foram criados quadros sinópticos para apresentação das características dos estudos e evidências apresentadas. Posteriormente, as informações foram analisadas à luz da literatura. Foram respeitados os aspectos 
éticos envolvendo os estudos, havendo integridade na apresentação das autorias dos artigos.

\section{Resultados e Discussão}

O Quadro 1 apresenta as características principais dos 9 estudos selecionados - autor, título do artigo, fonte, ano, resultados e considerações finais.

Quadro 1 - Caracterização dos estudos quanto a autores, título, fonte/ano e resultados/considerações

\begin{tabular}{|c|c|c|c|}
\hline Autor & Título do Artigo & Fonte/Ano & Resultado/Considerações finais \\
\hline $\begin{array}{l}\text { Baixinho e Dixe } \\
(2020)\end{array}$ & $\begin{array}{l}\text { Quais as práticas dos } \\
\text { cuidadores para } \\
\text { prevenir as quedas } \\
\text { nos idosos } \\
\text { institucionalizados? }\end{array}$ & SciELO/2020 & $\begin{array}{l}\text { Nos domínios da aplicação das } \\
\text { medidas/orientações de segurança, } \\
\text { da prevenção da queda durante a } \\
\text { execução de cuidados, das práticas } \\
\text { relacionadas com o ambiente físico e } \\
\text { das práticas de informação e } \\
\text { formação do idoso adotado são } \\
\text { positivas e mantidas na maioria das } \\
\text { vezes. }\end{array}$ \\
\hline $\begin{array}{l}\text { Chini; Pereira e } \\
\text { Nunes (2019) }\end{array}$ & $\begin{array}{ll}\text { Validação } & \text { da } \\
\text { Ferramenta } & \text { de } \\
\text { Rastreio de Risco de } \\
\text { quedas (FRRISque) em } \\
\text { pessoas idosas que } \\
\text { vivem na comunidade. }\end{array}$ & SciELO/2019 & $\begin{array}{l}\text { Este estudo teve o propósito de } \\
\text { validar uma escala para avaliar o risco } \\
\text { de quedas em pessoas idosas que } \\
\text { vivem na comunidade, buscando } \\
\text { preencher a lacuna na literatura de } \\
\text { um instrumento simples, porém } \\
\text { denso, de rápida aplicação e baixo } \\
\text { custo. }\end{array}$ \\
\hline $\begin{array}{l}\text { Carvalho et al. } \\
(2010)\end{array}$ & $\begin{array}{l}\text { O olhar e o sentir do } \\
\text { idoso pós-queda. }\end{array}$ & SciELO/2010 & $\begin{array}{l}\text { Alertar a família e a comunidade } \\
\text { sobre os fatores de risco aos quais os } \\
\text { idosos estão expostos é uma das } \\
\text { estratégias que podem ser adotadas } \\
\text { pelos profissionais de saúde, uma vez } \\
\text { que cabe a estes o papel de atender de } \\
\text { forma satisfatória e holística às } \\
\text { necessidades daqueles que muito } \\
\text { contribuíram para a sociedade. }\end{array}$ \\
\hline Fhon et al. (2013) & $\begin{array}{l}\text { Prevalência de quedas } \\
\text { de idosos em situação } \\
\text { de fragilidade. }\end{array}$ & SciELO/2013 & $\begin{array}{l}\text { A atenção à saúde do idoso frágil, } \\
\text { principalmente diante de maior } \\
\text { expectativa de vida e das diversas } \\
\text { síndromes decorrentes do processo } \\
\text { de envelhecimento, exige maior } \\
\text { investimento em estratégias de } \\
\text { promoção da saúde e prevenção de } \\
\text { agravos. Dentre esses agravos, a } \\
\text { avaliação de riscos de quedas, bem } \\
\text { como a formação de recursos }\end{array}$ \\
\hline
\end{tabular}




\begin{tabular}{|c|c|c|c|}
\hline & & & $\begin{array}{l}\text { humanos preparados são uma } \\
\text { estratégia fundamental para a atenção } \\
\text { de saúde dessa população. }\end{array}$ \\
\hline Guimarães (2013) & $\begin{array}{l}\text { Queda do idoso: } \\
\text { uma abordagem } \\
\text { multicausal. }\end{array}$ & $\begin{array}{l}\text { Google } \\
\text { Acadêmico } \\
\text { / } 2013\end{array}$ & $\begin{array}{l}\text { O aumento da proporção de idosos na } \\
\text { população mundial, e marcadamente } \\
\text { na brasileira, traz à tona a discussão a } \\
\text { respeito de eventos incapacitantes } \\
\text { dessa faixa etária, dentre as quais as } \\
\text { quedas, bastante comuns e temidas } \\
\text { pelos idosos. }\end{array}$ \\
\hline Luiz e Brum (2015) & $\begin{array}{l}\text { Prevalência e fatores } \\
\text { de risco de queda em } \\
\text { idosos no domicílio: } \\
\text { revisão integrativa da } \\
\text { literatura. }\end{array}$ & $\begin{array}{l}\text { Google } \\
\text { Acadêmico/2 } \\
015\end{array}$ & $\begin{array}{l}\text { É importante considerar alterações no } \\
\text { domicílio que o tornem um ambiente } \\
\text { mais saudável e seguro, facilitando o } \\
\text { trânsito dos idosos e o } \\
\text { desenvolvimento de atividades de } \\
\text { vida diárias e, por consequência, } \\
\text { diminuía os fatores de risco para } \\
\text { quedas. }\end{array}$ \\
\hline Nascimento (2019) & $\begin{array}{l}\text { Queda em adultos } \\
\text { idosos: considerações } \\
\text { sobre a regulação do } \\
\text { equilíbrio, estratégias } \\
\text { posturais e exercício } \\
\text { físico. }\end{array}$ & $\begin{array}{l}\text { Google } \\
\text { Acadêmico/2 } \\
019\end{array}$ & $\begin{array}{l}\text { O papel dos sistemas sensoriais } \\
\text { responsáveis pela regulação do } \\
\text { controle postural, destacar as } \\
\text { diferentes estratégias utilizadas por } \\
\text { idosos para a manutenção do } \\
\text { equilíbrio, além de exibir o potencial } \\
\text { da prática regular do exercício físico } \\
\text { na prevenção de quedas da } \\
\text { população idosa. }\end{array}$ \\
\hline Rodrigues (2019) & $\begin{array}{lr}\text { Prevalência } & \text { de } \\
\text { quedas em } & \text { idosos } \\
\text { cadastrados } & \text { na } \\
\text { atenção primária à } \\
\text { saúde. }\end{array}$ & $\begin{array}{l}\text { Google } \\
\text { Acadêmico/2 } \\
019\end{array}$ & $\begin{array}{l}\text { Os idosos, principalmente as } \\
\text { mulheres, após cair, desenvolvem } \\
\text { comportamentos que interferem } \\
\text { diretamente na qualidade de vida e } \\
\text { nas atividades para o autocuidado e } \\
\text { os afazeres domésticos, uma vez que } \\
\text { esta é a ocupação da maioria. }\end{array}$ \\
\hline $\begin{array}{l}\text { Santos e Medeiros } \\
(2020)\end{array}$ & $\begin{array}{l}\text { Quedas em idosos: } \\
\text { uma revisão de } \\
\text { literatura - principais } \\
\text { aspectos fisiológicos } \\
\text { e medidas de } \\
\text { prevenção. }\end{array}$ & $\begin{array}{l}\text { Google } \\
\text { Acadêmico/2 } \\
020\end{array}$ & $\begin{array}{l}\text { Pode-se compreender também que, } \\
\text { além do avanço da idade, algumas } \\
\text { alterações provocadas pelo } \\
\text { envelhecimento de ordem física e } \\
\text { mental contribuem } \\
\text { significativamente para o aumento da } \\
\text { incapacidade funcional e, } \\
\begin{array}{l}\text { consequentemente, para que as } \\
\text { quedas voltem a ocorrer. }\end{array}\end{array}$ \\
\hline
\end{tabular}

Fonte: Elaboração dos autores.

\section{Os estudos científicos apresentaram uma literatura esclarecedora}

quanto ao tema pesquisado, apresentando medidas e orientações de segurança,

a fim de avaliar o risco de quedas em pessoas idosas. Demonstrou-se o papel da

família nos cuidados entre idosos, que requerem maior atenção, pois sua saúde 
encontra-se fragilizada. Enfatizou-se que a mulher é a que mais sofre quando cai, pois apresenta fraturas que a deixa impossibilitada de cumprir com suas obrigações do lar.

Vários fatores estão associados à queda dos idosos portadores de doenças que se manifestam na velhice. De acordo com Nascimento (2019), as quedas são problemas comuns na população idosa, sendo consideradas como questão de saúde pública, responsáveis por alto grau de morbidade e mortalidade. Isso evidencia a realização de estudos teóricos que qualifiquem o entendimento sobre a relação entre queda e seus fatores de risco; a fisiopatologia dos distúrbios do equilíbrio e da marcha; e a identificação precoce da "queda idiopática" (sem causa evidente).

Para minimizar os casos de queda em idosos, é necessário um olhar mais amplo da família aos locais mais visitados pelo idoso. Assim, Baixinho e Dixe (2020) afirmam que investigações na área das quedas na população idosa têm sido produtivas nos últimos anos, o que tem possibilitado a descrição dos fatores de risco em diferentes contextos, bem como as medidas preventivas com evidência para o controle do risco, da queda, das lesões secundárias e da sua gravidade.

Segundo Rodrigues (2019), os episódios de queda apresentam características multifatoriais que dentro da sua complexidade possuem diversos fatores de risco, sendo assim, é muito raro determinar uma causa única para o acontecimento da queda.

É essencial garantir que o risco de queda seja menor na velhice, momento em que se deve ter mais cuidados, pois a recuperação é lenta e pode desencadear outros problemas. Portanto, a família deve estar presente, apoiando e cuidando do idoso. Conforme Guimarães (2013), a queda ocorre com mais frequência, entre idosos que apresentam múltiplas patologias. Para sua prevenção é fundamental a avaliação de equipe multidisciplinar, quanto aos aspectos da senescência e senilidade e ao ambiente físico psicossocial, visando o desenvolvimento da proposta de intervenção, para a melhoria da qualidade de vida do idoso. É fundamental, portanto, a participação efetiva da família, a fim 
de manejar situações com o paciente idoso, principalmente no que diz respeito à segurança deste.

De acordo com Luiz e Brum (2015), as quedas podem ter consequências graves nessa população, uma vez que, na velhice, há diminuição de hormônios que auxiliam a fixação do cálcio nos ossos, aumentando o risco de osteoporose e, por conseguinte, de fraturas ósseas. Esses autores afirmam ainda que o banheiro é um dos locais considerados mais perigosos para o idoso, pois é o lugar que ele mais transita durante o dia e à noite. A ausência de barra de apoio proporciona um aumento de quedas justamente pelo fato de o chão do banheiro ser uma área escorregadia em razão da extensa passagem de água pelo chuveiro. Logo, é fundamental que os familiares tenham consciência sobre essas inadequações.

É importante destacar que a mulher sempre é mais prejudicada quando acometida a queda, pois ela exerce funções importantes dentro do lar. Segundo Barbosa (2019), os idosos, principalmente as mulheres, após cair, desenvolvem comportamentos que interferem diretamente na qualidade de vida e nas atividades para o autocuidado e os afazeres domésticos, uma vez que esta é a ocupação da maioria. Além disso, a existência de múltiplas complicações, comprometimento físico, decorrente de fraturas, agravos psicoemocionais e o medo de voltar a cair, são responsáveis por prejudicar a mobilidade funcional do idoso, deixando-os dependentes diante de suas atividades de vida diária.

Segundo Luiz e Brum (2015), a maior prevalência de quedas de idosos em domicílios está associada ao sexo feminino, em razão de fatores endógenos (menopausa, com baixa de hormônios femininos que predispõem a osteoporose) e de hábitos sociais (maior participação das mulheres no desenvolvimento de tarefas domésticas); idade mais avançada, dado o maior comprometimento dos sistemas cognitivos e fragilidade muscular e óssea; e episódios anteriores de quedas.

A prevenção é o único meio de evitar a queda do idoso, ou reduzir sua gravidade. Para que isso aconteça, devem ser adotadas adaptações que facilitem a vida do idoso. Guimarães (2013) afirma que devido à grande frequência e 
importância de quedas de idosos, faz-se necessário buscar estratégias para evitálas. Portanto, é de fundamental importância a realização de ações que diminuam esses fatores, como: avaliação do ambiente domiciliar e a realização de adaptações na residência dos idosos, seja por parte dos profissionais de saúde que cabe detectar, orientar e supervisionar os familiares de idosos quanto às necessidades de cada idoso. Para tanto, os familiares precisam atender às solicitações e sugestões dos profissionais para o êxito da intervenção e minimização dos riscos e danos.

Santos e Medeiros (2020), consideram que nem sempre as quedas são possíveis de serem evitadas. Em alguns desses eventos, as consequências exigem tratamento médico, acompanhamento em casa, uso de remédios, além da mudança no estilo de vida, prática de atividades físicas e alimentação diferenciada. Consequentemente, todas essas alterações impactam na economia de um modo geral e requerem planejamento a nível governamental e individual.

Segundo Chini; Pereira e Nunes (2019), contudo, empregar tais estratégias de prevenção, implica em ter um instrumento de rastreamento ou avaliação do risco de quedas em pessoas idosas. No cenário da atenção primária, profissionais de saúde requerem instrumentos que os possibilitem identificar o risco de quedas. Ou seja, necessitam de um instrumento simples, porém consistente, que identifique idosos com menor e maior risco para quedas para que possam desenvolver estratégias para a prevenção de quedas nesta população.

De acordo com Luiz e Brum (2015), é importante considerar alterações no domicílio que o tornem um ambiente mais saudável e seguro, facilitando o trânsito dos idosos e o desenvolvimento de atividades de vida diárias e, por consequência, diminua os fatores de risco para quedas. Ações de promoção e prevenção devem ser implementadas pelos familiares e pelos profissionais de saúde, que têm papel fundamental na educação em saúde, a qual subsidia o conhecimento, a adesão às mudanças impostas pelo envelhecimento e o autocuidado. 
A família sempre será o porto seguro para os idosos, para que eles se sintam valorizados e possam contribuir nas atividades diárias, prevenindo possíveis acidentes. Para Rodrigues (2019), a valorização da pessoa idosa apresenta diversas mudanças diante de vários paradigmas. O idoso é visto como um indivíduo doentio incapaz de exercer suas próprias atividades, representando assim um incômodo no meio familiar. Diante dessa concepção o sujeito idoso é visto como algo penoso que causa angústia e tormento para os familiares, gerando exclusão social.

O cuidado na velhice é importante, pois a reincidência de queda nesta fase pode ser crucial para a vida do idoso. Em muitos casos, a família não está preparada para cuidar do idoso, recorrendo de um cuidador, que passa a ser um gasto afixado às despesas com remédios e outras necessidades. Fhon et al. (2013) consideram que os idosos com quedas recorrentes, que também apresentam certo grau de fragilidade, podem ser considerados um grupo de alto risco para novas quedas. As consequências podem ser leves ou graves, o que pode gerar alto custo para a sociedade (gastos com hospitalização, tratamento e reabilitação), e custos significativos para a família em razão da necessidade de mudança do ambiente físico, dependência e cuidado do idoso por algum familiar ou cuidador particular.

A falta de responsabilidade com o idoso pode acarretar a inúmeros problemas físicos e psicológicos. De acordo com Rodrigues (2019), o suporte familiar na vida do idoso, durante o processo de envelhecimento, contribui de forma significativa diante de suas fragilidades físicas e psicológicas. $\mathrm{O}$ meio familiar pode definir o comportamento e as particularidades do idoso, assim em família com estilo de vida saudável e harmoniosa entre todos, incluindo o idoso, desencadeia um crescimento de qualidade no meio familiar e nas atividades desenvolvidas na vida dele, mantendo uma relação de respeito, sem exclusão ou frustrações, de modo que o idoso evite um isolamento familiar e social.

Em muitos casos de acompanhamento de idosos que sofreram quedas, a família não está preparada para dar o apoio essencial para sua recuperação, por não ter conhecimentos específicos para a situação vivenciada. Desta forma, 
Carvalho et al. (2010) esclarecem que com a queda, o idoso se vê dependente, muitas vezes, de pessoas despreparadas a lidar com limitações e dependência, sejam familiares ou terceiros, que o agridem tanto física como verbalmente. Isso gera na pessoa idosa um sentimento de exclusão e rejeição, com tendência ao isolamento.

\section{Conclusão}

A população idosa vem crescendo em todo o mundo, para garantir uma vida saudável vários fatores que envolvem sua segurança devem ser realizados, impedindo que o idoso se sinta uma pessoa que não tem mais valor. Nessa idade é que a família deve valorizar e ter os cuidados necessários para que ele possa interagir em atividades de acordo com sua disposição, sem que possa causar danos à sua saúde.

A queda do idoso pode estar associada às características multifatoriais por meio da hereditariedade por fatores múltiplos, genéticos e não genéticos. É nesta perspectiva que a prevenção se torna o meio mais eficaz de garantir que o idoso não sofra uma queda, uma vez que a idade avançada apresenta ausência de cálcio, responsável pelo fortalecimento dos ossos, redução na produção de hormônios, e em outros casos há manifestação da osteoporose.

Vale ressaltar que a mulher é quem mais sofre quando cai, pois, é dela as funções do lar. O estudo apresentou em sua literatura que a mulher apresenta fatores endógenas alterados que a impossibilita do regresso às atividades e hábitos sociais. Portanto, os fatores expostos deixam o idoso dependente da família, ou de cuidadores para retornar gradativamente suas atividades, pois o medo de cair se torna frequente, prejudicando sua mobilidade funcional. 
Por fim, o estudo atingiu seus objetivos, ao elencar todos os pontos traçados na introdução, quando se buscou apresentar os riscos de queda na velhice, o papel da família para proteger o idoso, e estratégias de prevenção e tratamento especializado para o idoso vítima de queda. Ressalta-se ainda, que o estudo encontrou poucas publicações sobre o tema. Portanto, é essencial que futuros estudos sejam realizados para ampliar as evidências sobre a temática. 


\section{Referências}

AMORIM, Juleimar Soares Coelho de et al. Prevalência de queda grave e fatores associados em idosos brasileiros: resultados da Pesquisa Nacional de Saúde, 2013. Ciência \& Saúde Coletiva, v. 26, n. 1, p. 185-196, 2021. Disponível em: https://www.scielo.br/j/csc/a/7Lmfj9DjT7y9pfkWs4zymJ/?lang=pt\#: :text= Pesquisa \%20Nacional \%20de\%20Sa \%C3\%BAde\%2C\%202013.,7\%2D8\%2C3). Acesso em: 19 ago. 2021.

BAIXINHO, Cristina Lavareda; DIXE, Maria dos Anjos. Quais as práticas dos cuidadores para prevenir as quedas nos idosos institucionalizados? Revista Baiana de Enfermagem, v. 34, p. 1-11, 2020. Disponível em:

http:// www.revenf.bvs.br/scielo.php?script=sci_arttext\&pid=S217886502020000100349. Acesso em: 1 ago. 2021.

BARBOSA, Amanda da Silveira et al. Caracterização dos incidentes de quedas de pacientes adultos internados em um hospital universitário. Revista Gaúcha de Enfermagem, v. 40, p. 1-10, 2019. Número especial. Disponível em: https://www.scielo.br/j/rgenf/a/3QVcZQvQTFCbwF5bDJTT4px/?format=p df\&lang=pt. Acesso em: 24 set. 2021.

CARVALHO, Emmanuela Maussuara Rocha et al. O olhar e o sentir do idoso pósqueda. Revista Brasileira de Geriatria e Gerontologia, v. 13, n. 1, p. 7-16, abr. 2010. Disponível em:

https://www.scielo.br/j/rbgg/a/Chggt9yYs4VMQPJCFx9hJgk/?lang=pt\#: :t ext $=\mathrm{O} \% 20$ olhar $\% 20 \mathrm{e} \% 20 \mathrm{o} \% 20$ sentir $\% 20$ do $\% 20 \mathrm{idoso} \% 20$ no $\% 20 \mathrm{p} \% \mathrm{C} 3 \% \mathrm{~B} 3 \mathrm{~s} \% 2 \mathrm{D}$ queda $\% 20$ * \&text $=$ RESUMO-

A \%20queda \%20de\%20idosos\%20\%C3\%A9\%20um\%20problema \%20de\%20rele v\%C3\%A2ncia\%20para,se \%20passa \%20ap\%C3\%B3s\%20esse\%20incidente.

Acesso em: 4 ago. 2021.

CHINI, Lucélia Terra; PEREIRA, Daniele Sirineu; NUNES, Atacílio Aparecido. Validação da ferramenta de rastreio de risco de quedas (FRRISque) em pessoas idosas que vivem na comunidade. Ciência \& Saúde Coletiva, v. 24, n. 8, p. 28452858, ago. 2019. Disponível em:

https://www.scielo.br/j/csc/a/8MM9xTbBhbZXLTZxprvwYPr/?lang=pt. Acesso em: 2 ago. 2021.

FHON, Jack Roberto Silva et al. Prevalência de quedas de idosos em situação de fragilidade. Revista de Saúde Pública, v. 47, n. 2, p. 266-273, jun. 2013. Disponível em: https:/ / www.scielosp.org/article/rsp/2013.v47n2/266-273/. Acesso em: 6 ago. 2021. 
GUIMARÃES, Renato Vinícius Alves. Queda do idoso: uma abordagem multicausal. 2013. 29 f. Monografia (Especialização em Atenção Básica em Saúde da Família) - Universidade Federal de Minas Gerais, Pompéu, 2013. Disponível em:

https://www.nescon.medicina.ufmg.br/biblioteca/imagem/4111.pdf. Acesso em: 10 jun. 2021.

LUIZ, Izabel Cristina; BRUM, Ana Karine Ramos. Prevalência e fatores de risco de queda em idosos no domićllio: revisão integrativa da literatura. Revista de Enfermagem UFPE On Line, v. 9, n. 10, p. 1556-1564, dez. 2015. Disponível em: https://periodicos.ufpe.br/revistas/revistaenfermagem/article/view/10870. Acesso em: 18 ago. 2021.

NASCIMENTO, Marcelo de Maio. Queda em adultos idosos: considerações sobre a regulação do equilíbrio, estratégias posturais e exercício físico.

Geriatrics, Gerontology and Aging, v. 13, n. 2, p. 103-110, 2019. Disponível em: http:// www.ggaging.com/details/534/pt-BR/ fall-in-older-adults-considerations-on-balance-regulation--postural-strategies--and-physicalexercise. Acesso em: 21 jul. 2021.

RODRIGUES, Danielly Barbosa. Prevalência de quedas em idosos cadastrados na atenção primária à saúde. 2019. 45 f. Trabalho de Conclusão de Curso (Graduação em Enfermagem) - Universidade Federal de Campina Grande, Campina Grande, 2019. Disponível em:

http:// dspace.sti.ufcg.edu.br:8080/jspui/handle/riufcg/11315. Acesso em: 6 ago. 2021.

SANTOS, Hélio Geraldo da Cruz; MEDEIROS, Fabiana Gonçalves de Mello Cachú. Quedas em idosos: uma revisão de literatura: principais aspectos fisiológicos e medidas de prevenção. In: CONGRESSO INTERNACIONAL DE ENVELHECIMENTO HUMANO, 7., 2020, Campina Grande. Anais [...]. Campina Grande: [s.n.], 2020. Disponível em: https://editorarealize.com.br/editora/anais/cieh/2020/TRABALHO_EV136_ MD1_SA2_ID1204_16072020123830.pdf. Acesso em: 29 de jul. 2021.

SANTOS, Tâmara. Risco de queda ameaça a qualidade de vida dos idosos. EcoDebate, 20 mar. 2021. Disponível em:

https:// www.ecodebate.com.br/2021/03/20/risco-de-queda-ameaca-aqualidade-de-vida-dos-idosos/. Acesso em: 23 jul. 2021.

SÃO PAULO. Secretaria de Estado da Saúde. Relatório global da OMS sobre prevenção de quedas na velhice. São Paulo: Secretaria de Estado da Saúde, 2010. Disponível em:

https://bvsms.saude.gov.br/bvs/publicacoes/relatorio_prevencao_quedas_ve lhice.pdf. Acesso em: 25 jul. 2021. 


\section{4}

Repercussões do contexto

de trabalho do enfermeiro

nas suas dimensões de vida 


\title{
4 REPERCUSSÕES DO CONTEXTO DE TRABALHO DO ENFERMEIRO NAS SUAS DIMENSÕES DE VIDA
}

\author{
Brenda Rayane Carneiro \\ Daniele Vasconcelos Fernandes Vieira \\ Franscica Gomes Montesuma \\ Ivando Amancio da Silva Júnior \\ Gislene Holanda de Freitas \\ André Ribeiro de Castro Júnior
}

\section{Resumo}

Objetivo: Identificar os componentes da dimensão profissional do enfermeiro que interferem no seu bem-estar e qualidade de vida. Dada à natureza da investigação, trata-se, portanto, de uma pesquisa de caráter qualitativo e exploratório. Método: A pesquisa foi realizada em um hospital de referência no Ceará na unidade de terapia intensiva. A população do estudo foi composta por 06 enfermeiros, do sexo feminino, assistenciais atuantes em uma unidade de terapia intensiva (UTI). O instrumento de coleta de dados foi a entrevista aberta, posteriormente, analisada segundo análise temática de Minayo (2013). A coleta de dados ocorreu entre os meses de junho e julho de 2016. Resultados: Considerou-se que os componentes existentes na rotina do enfermeiro que influenciam no cuidado da própria saúde do profissional: jornadas elevadas além da capacidade humana e precariedade de trabalho. Considerações Finais: Esses elementos são geradores de desgastes físicos e mentais afetando diretamente as demais dimensões de vida desses profissionais, a qualidade de vida e saúde bem como comprometendo a qualidade da prestação da assistência.

Palavras-chave: Enfermagem. Bem-estar. Qualidade de Vida no Trabalho. 


\section{Introdução}

O objeto de estudo para pesquisa foi escolhido a partir da vivência com profissionais de enfermagem que apresentavam discurso negativo acerca da insatisfação da vida pessoal relacionado à profissão. Diante de tal fato, surgiu o interesse de pesquisar como as atividades e o contexto de trabalho de enfermagem pode influenciar na vida pessoal desses profissionais. Além de entender a importância que se tem de estudar sobre o tema, para que profissionais e alunos do curso de graduação em enfermagem possam identificar tais repercussões e buscar a preservação das saúdes e do bem-estar.

Desde a origem da profissão de enfermagem moderna, que segundo Kruse (2006), nasce como uma prática coadjuvante da prática médica e que, como tal, se constrói dentro da instituição hospitalar e a partir do saber médico constituído na modernidade, perpassa-se a ideologia de abnegação, dedicação e devotamento. Na qual, é evidenciado pelo fato de que as estudantes deveriam deixar suas casas e dedicar-se ao alívio do sofrimento e salvação de vidas. Existem atualmente conflitos dos profissionais enfermeiros entre a assistência pautada nessa ideologia e a organização capitalista produtivista dos hospitais e do sistema de saúde.

Os profissionais enfermeiros, de um modo geral, têm grande responsabilidade sobre o bem-estar e a vida do outro. Por isso, é necessário que estes desenvolvam habilidades e competências que permitam tomar o cuidado como objeto profissional e proporcionar a promoção da saúde, prevenção de agravos e reabilitação de enfermidades.

O profissional enfermeiro ainda na academia tem conhecimento dessa responsabilidade e se capacita para prestar assistência de forma eficiente e eficaz. Porém existe uma grande diferença entre o ideal e o real, tendo esses enfermeiros que trabalhar nas condições mais adversas, que inclui sobrecarga de trabalho, equipe insuficiente, falta de material, má remuneração, longas jornadas de trabalho, pressão da organização do sistema hospitalar fazendo com que os 
profissionais convivam, cotidianamente, com situações limites e elevados níveis de tensão. Isso reforça o adoecimento psicoemocional e físico dos trabalhadores colocando em risco a vida do próprio profissional e de seus pacientes.

Segundo Elias e Navarro (2006), o trabalho de enfermagem é preservado pelas suas características históricas de cuidado ao outro, porém no seu cotidiano, o enfermeiro se depara com problemas de diversas ordens, sendo pressionado a desempenhar atividades que extrapolam suas limitações, acumulando funções e transformando a prestação da assistência e do cuidado aos pacientes em algo mecanizado. A realidade dos problemas enfrentados pelos trabalhadores enfermeiros em seu ambiente de trabalho, como imposições institucionais, relações verticalizadas, alienação, subordinação, competitividade e hierarquização repercute negativamente na qualidade de vida no trabalho e consequentemente pode levar ao adoecimento físico e mental desses profissionais.

Para Ramos et al. (2014), o caráter competitivo que se assume nessa área em decorrência da insegurança do desemprego é responsável por motivar os profissionais a submeterem-se a acordos de trabalho com baixos salários, ambientes insalubres, colocando sua vida em risco e tornando-os cada vez mais ansiosos e doentes.

Segundo Silva et al. (2009), os enfermeiros têm dificuldade em praticar o cuidado consigo mesmo, apesar da sua formação que tem por objeto de trabalho o cuidado. $\mathrm{O}$ artigo também discute sobre o comportamento ético que é assumido através de práticas como a promoção da própria saúde, despertando responsabilidade e preocupação com o viver.

Diante disso, vale ressaltar a importância da identificação de fatores que interferem na qualidade de vida no trabalho para que estes profissionais busquem reflexão sobre estratégias adequadas para manutenção de suas demais dimensões de vida. Encontram-se dentro dessas outras dimensões de vida: relações pessoais e sociais bem estruturadas, com amigos e familiares participando ativamente, descanso adequado, preservação das suas saúdes física, 
emocional, mental, espiritual e social que irão auxiliar na promoção da qualidade de vida dos profissionais enfermeiros.

Diante do exposto, questiona-se de que modos o contexto de trabalho do profissional enfermeiro reflete em suas demais dimensões de vida pessoal?

Levando em consideração o interesse em compreender de que modos o contexto de trabalho do profissional enfermeiro reflete em suas demais dimensões de vida, essa pesquisa se destina a contribuir para as reflexões, pela ótica do profissional, a respeito de qualidade de vida no trabalho e seus desdobramentos nas suas demais dimensões de vida.

Sendo o tema destinado à categoria de enfermeiros, os dados adquiridos nessa pesquisa poderão agregar marcadores que, possibilitarão identificar e refletir sobre os contextos da vida profissional que interferem nas demais dimensões de vida do enfermeiro, de forma que possam gerar incentivos na produção de outros modos de pensar as suas relações e interações com a família, o lazer, a vida amorosa, suas práticas de cuidado e suas prioridades para o viver com bem-estar e qualidade.

\section{Objetivo}

Identificar os fatores existentes na ambiência do trabalho que impactam na qualidade de vida dos profissionais enfermeiros.

\section{Método}

O estudo que foi realizado nessa pesquisa é de caráter descritivo, tendo em vista a ótica de que as pesquisas deste tipo têm como objetivo primordial a descrição das características de determinada população ou fenômeno ou o estabelecimento de relações entre variáveis (GIL, 2008) e exploratório, segundo a perspectiva de que as pesquisas exploratórias têm como principal finalidade desenvolver, esclarecer e modificar conceitos e ideias, tendo 
em vista a formulação de problemas mais precisos ou hipóteses pesquisáveis para estudos posteriores (GIL, 2008).

Essa pesquisa foi realizada em uma unidade de terapia intensiva de um hospital público de referência no estado do Ceará. O maior hospital público da rede estadual, referência em procedimentos de alta complexidade. Integra a rede de Hospitais Sentinelas, Hospital Amigo da Criança, Rede Cegonha e, programa SOS Emergência, do Ministério da Saúde. É referência em 63 especialidades e subespecialidades. O hospital é integrado ao Sistema Único de Saúde na rede assistencial da Secretaria da Saúde do Estado do Ceará (SESA), órgão do Poder Executivo.

Tem como missão prestar assistência à saúde da população como hospital do Sistema Único de Saúde de referência em procedimentos de alta complexidade, ofertando serviços humanizados, seguros e de boa qualidade, contribuindo para a produção e transmissão de conhecimentos em sua área de atuação.

A população do estudo foi composta por 6 enfermeiros, do sexo feminino, assistenciais atuantes em uma unidade de terapia intensiva (UTI). Foram considerados como critérios de inclusão enfermeiros que exercem assistência em plantão diurno, no período das 13h às 17h, com escala fixa, no qual a pesquisadora terá acesso ao campo de coleta. Foram excluídos os profissionais que não estavam escalados durante o período de coleta de dados.

Os participantes foram contatados pela pesquisadora no momento de sua visita à unidade de terapia intensiva, quando foram convidados a participar da pesquisa. Aqueles que aceitaram participar assinaram o termo de consentimento livre e esclarecido (TCLE) (Anexo A).

A coleta teve como técnica a entrevista aberta com uma questão norteadora condizente com o objetivo da pesquisa (Apêndice A). A entrevista aberta ou não estruturada permite ao entrevistado responder perguntas dentro da sua própria estrutura de referências (MAY, 2004) e segundo Gil (2008) se distingue da simples conversação porque tem como objetivo básico a coleta de 
dados. Todas as entrevistas foram gravadas para melhor fidedignidade das falas dos sujeitos.

A coleta de dados ocorreu entre os meses de junho e julho de 2016 e foi realizada somente após o convite e a aceitação da participação dos enfermeiros na pesquisa, através da assinatura do TCLE (Anexo A), no qual está descrito os objetivos, riscos, benefícios e método da pesquisa, além de conter os aspectos éticos e os direitos do pesquisado ao concordar em participar da pesquisa.

Os dados coletados da entrevista foram categorizados segundo as categorias temáticas de Minayo (2013), que correspondem à ordenação, classificação e análise propriamente dita. O tratamento do material nos conduz à teorização sobre os dados, produzindo o confronto entre a abordagem teórica anterior e o que a investigação de campo aporta de singular como contribuição (MINAYO, 2013). Também foi realizada com base na revisão de literatura que sustentou as relações estabelecidas entre o contexto de trabalho do profissional enfermeiro e suas demais dimensões de vida.

As falas dos sujeitos foram codificadas utilizando nomes de flores. E organizados segundo as categorias temáticas que emergiram dos discursos.

Após a submissão e aprovação pelo Comitê de Ética em Pesquisa da Universidade Estadual do Ceará, conforme número do Parecer $\mathrm{n}^{\mathrm{o}}$ 56795116.9.0000.5534, tendo por diretrizes os critérios éticos de pesquisa junto a seres humanos, segundo a Resolução CNS n ${ }^{\circ}$ 466/12, do Conselho Nacional de Saúde, os critérios éticos foram contemplados garantindo a autonomia do pesquisado à livre entrada ou saída da pesquisa sem lhe acarretar danos ou ofensas, mantendo em sigilo a identidade dos entrevistados, garantindo que danos previsíveis sejam evitados, assegurando aos sujeitos da pesquisa liberdade para opinar sobre suas próprias informações na pesquisa e por fim comprometendo-se com o máximo de benefícios e o mínimo de riscos (BRASIL, 2013).

A pesquisa tem como benefícios contribuir para reflexão do enfermeiro sobre o cuidado consigo mesmo e colaborar para as discussões sobre 
qualidade de vida no trabalho de enfermagem. Os riscos da pesquisa consistem em exposição da imagem, constrangimento, violação da intimidade, despertar emoções desequilibradas/negativas e ativar memórias traumáticas.

Os participantes da pesquisa foram orientados quanto aos objetivos do estudo; assinaram o TCLE (Anexo A), no qual estão descritos os riscos, benefícios e método da pesquisa, além de conter os aspectos éticos e os direitos do pesquisado ao concordar em participar da pesquisa.

\section{Resultados e Discussões}

No que se refere às características dos profissionais entrevistados, foram enfermeiros atuantes na unidade de terapia intensiva de um hospital referência do Ceará. A amostra foi composta por seis enfermeiros do sexo feminino e se constituiu predominantemente por jovens adultos com faixa etária de 29 a 45 anos. Quanto à situação conjugal, duas profissionais da amostra eram divorciadas $(33,3 \%)$, duas profissionais casadas $(33,3 \%)$ e duas profissionais solteiras (33,3\%). Quanto à distribuição das profissionais por turno de trabalho, a amostra ficou constituída por quatro enfermeiras no turno da manhã, duas enfermeiras no turno da tarde e nenhuma profissional no período noturno.

\section{Entrevistas com as enfermeiras participantes}

Primeiramente, entendo que o processo de entrevista é composto de várias etapas e para dar início me senti receosa devido ao fato de que minha pergunta adentra na vida pessoal de cada entrevistada. Não sabia o que esperar, não sabia quais seriam as reações, mas foi bem recebida e consegui aplicar a entrevista.

De início as entrevistadas tiveram dificuldade para responder à pergunta de forma clara, porém após uma explicação prévia e exemplificada, iniciou-se uma conversa aberta. Algumas entrevistadas queixaram-se da falta de 
tempo para responder a entrevista, porém ao longo da conversa foram abrindose para a proposta.

O fato de já conhecer a maioria das profissionais, devido minha experiência no internato, foi facilitador para que estas pudessem se expressar livremente.

Para a coleta e produção das informações as participantes, após assinarem o termo de consentimento livre e esclarecido, responderam a uma pergunta norteadora, condizente com o objetivo da pesquisa, na qual permitia aos indivíduos interagir livremente com o entrevistador, também manifestar-se de forma clara e através de diferentes possibilidades de expressão.

Tais sujeitos foram selecionados aleatoriamente, considerando-se, porém, sua disponibilidade para a participação no estudo. Para garantir o anonimato, as enfermeiras foram denominadas: Orquídea, Lírio, Tulipa, Rosa, Ipê, e Girassol, denominação esta escolhida pela pesquisadora e aceita pelas profissionais.

A primeira entrevistada foi a Rosa, 43 anos, casada e com um filho. Ela começou relatando momentos vividos por conta das dificuldades que a profissão apresenta, como carga horária elevada, sobrecarga de trabalho e doação para cuidados com o paciente.

\footnotetext{
Cansei das vezes que chegava em casa cansada do plantão e me colocava para dormir e acordava com os sons das bombas. Cansei das vezes que acordei assustada como se estivesse no plantão [...] Às vezes que meu filho acordava e perguntava se eu já iria trabalhar novamente [...] Que deixei meu marido dormindo, porque ele saia mais tarde para trabalhar, e ele nem me via sair, e isso era uma coisa recorrente, como aconteceu vezes que passei dois dias sem vê-lo (Rosa).
}

Durante a entrevista indaguei a enfermeira sobre atividades específicas que ocorrem na sua rotina de trabalho que influenciam direta e indiretamente sobre suas outras dimensões de vida e o discurso dela foi o seguinte: 


\begin{abstract}
São muitas atividades. As mais importantes que geram muito cansaço físico e mental é o próprio cuidado com o paciente crítico, você tem que estar sempre atento, e atrelado a isso existem os papéis, a burocracia geral. Ai tem a coordenação da equipe de enfermagem que nem sempre é fácil [...] É muito cansativo o plantão em si, é troca de curativo, é passagem de sonda vesical para coletar urinocultura, é diluição de antibióticos, é preenchimento de papel, é vai buscar isso, vai buscar aquilo, dá conta disso, dá conta daquilo e isso é o que acontece todos os dias, fora em alguns dias excepcionais quando tem alguma parada ou algum procedimento que temos que auxiliar o médico [...] e tem mais, quando sua colega falta e você tem que dobrar plantão? É altamente exaustivo, eu já estou cansada do meu plantão e aí vou me cansar duas vezes mais por ter que assumir esse outro plantão, aí quando eu chego em casa só quero dormir, esqueço até de comer. Minha casa às vezes tá uma bagunça, porque chego sete horas da noite cansada e no outro dia já tenho que tá de pé cinco horas da manhã, aí vai acumulando as tarefas de casa. Enfim, vivo cansada e sem tempo (Rosa).
\end{abstract}

Para finalizar Rosa expõe a enfermagem entre seus benefícios por ser uma profissão gratificante e seus malefícios por acarretar a ela problemas psicossociais. Ela não consegue conciliar o cuidado consigo e o cuidado com o outro, o que fica evidenciado na fala abaixo quando ela cita que o trabalho de enfermagem é sacrificante, pois precisa trocar o cuidado da sua família para ter que cuidar do outro.

Enfermagem é uma profissão muito bonita, mas é uma profissão difícil porque realmente tem que se doar para conseguir alguma coisa na sua vida, conseguir alguma coisa para os seus pacientes porque o serviço em si é difícil [...] É mesmo muito sacrificante você ter que deixar o cuidado da sua família e das pessoas que fazem parte do seu convívio e da sua vida para se doar e cuidar de outras pessoas que você não conhece o que é gratificante, porém é como se estivesse trocando uma coisa pela outra (Rosa).

A segunda entrevistada foi a Girassol, 33 anos, divorciada e com uma filha. Girassol sentiu se a vontade para compartilhar um relato de sua vida que segundo ela está concatenado com o trabalho de enfermagem. Falou sobre a falta de tempo, o estresse gerado por fatores gerais do trabalho e o desgaste físico e mental. Relatou que devido à rotina de trabalho intenso esqueceu-se de cuidar da sua aparência, da saúde física e da saúde das relações familiares. 
A enfermagem é a profissão que eu considero uma das mais árduas que existe [...] Fui casada durante dez anos e no último ano meu casamento veio ao fim, pois meu marido me falou que não aguentava mais o que a minha profissão estava fazendo comigo. Ele reclamava de uma série de coisas, que é triste relembrar e chega a me doer... Algumas dessas reclamações ele tinha total razão. Reclamava que eu não tinha tempo para família e ele sabia e via meu esforço de querer contribuir com a renda familiar, mas para ele isso não valia a pena, pois eu estava contribuindo com algo que eu não usufruía [...] Não estava incluída nos momentos em família, porque trabalhava em dois empregos e aos finais de semana. Não acompanhava o crescimento da minha filha [...] Esqueci-me de cuidar do meu corpo, da minha pele, da minha saúde, estava sem vaidade, vivia preocupada, estressada e levava a minha cabeça cheia para casa, e isso refletia no meu marido e na minha filha, principalmente (Girassol).

Quando questionada sobre o comprometimento da sua assistência devido ao perfil destrutivo, que no caso dela, configura-se como a aceitação da sobrecarga de trabalho, ela referiu que se preocupava com o bem-estar dos seus pacientes, porém não o fazia de forma eficiente e eficaz.

Amo o que faço e realmente me preocupo com o bem-estar e sempre quero fazer o melhor pelo paciente, mas admito que quando estamos exaustas e esgotadas acabamos mecanizando aquilo que estamos fazendo [...] O raciocínio clínico parece que não flui, sabe? O cansaço físico toma conta da gente, e por consequência começamos a fazer só o básico ou às vezes, até menos que isso (Girassol).

A literatura mostra, como foi dito anteriormente, que os profissionais podem assumir dois perfis, o perfil favorável e o perfil destrutivo. $O$ perfil favorável consiste na busca por crescimento profissional, manutenção das interações sociais, das relações pessoais, manutenção das saúdes mental, física e espiritual e pela busca de estratégias de enfrentamento de situações desfavoráveis. Já o perfil destrutivo é aquele se expõem a sobrecarga de trabalho, más condições de trabalho, falta de autonomia, alienação e subordinação.

Girassol finalizou relatando que após tal acontecimento, começou a identificar os fatores destrutivos em sua vida e que atualmente busca por um perfil favorável para a manutenção da saúde, mental, física, espiritual e boa interação social. 
Após sofrer o choque da minha separação comecei a repensar sobre minha vida e atualmente consigo conciliar meu trabalho com minha vida pessoal de forma mais satisfatória [...] hoje tenho apenas um emprego, fico mais tempo em casa, vou passear com minha filha, frequento mais a igreja e tento fazer caminhada (Girassol).

A terceira a ser entrevistada foi a Tulipa, 29 anos, solteira. Esta começou falando que responderia a minha pergunta em uma só palavra: tudo. Todos os contextos de trabalho influenciam em sua vida. Colocou em questão a condição de adoecimento do paciente e a responsabilidade de lhe dar com vidas. Mencionou ainda sobre a mecanização do trabalho e se mostrou bastante preocupada por ver essa realidade cada vez na sua prática.

Tudo. Minha vida é totalmente influenciada pelo meu trabalho, meu senso de responsabilidade com o ser cliente e com a doença do paciente e as questões sociais que englobam todo o contexto da doença junto com a realidade do paciente e sua família. Mas acredito que muitas pessoas que trabalham na área, não tem responsabilidade com o que realmente estão fazendo, tornando um trabalho mecânico, o que muito me irrita e chateia, pois o paciente não tem nada a ver com os problemas pessoais dos profissionais (Tulipa).

Tulipa ainda relatou que se sente sobrecarregada psicologicamente com a própria essência da profissão que é estar encarregada de cuidar da vida do outro, para ela isso é um fator comprometedor da saúde mental.

E sabe o que acontece, a enfermagem é uma profissão por si só tendenciosa a comprometer a saúde, essa tensão toda que é ser responsável pela vida do outro, adoece a gente mentalmente, estamos sempre pressionando a nós mesmos para não cometermos erros... Isso sobrecarrega nosso psicológico (Tulipa).

A enfermeira finalizou discorrendo sobre pontos que foram citados anteriormente, como desvalorização social da profissão e remuneração inadequada.

Essa ausência de reconhecimento profissional vem tanto de fora como de dentro. A sociedade diminui o trabalho de enfermagem, é a secretaria do médico, só aplica injeção, algumas pessoas nem sabem que é um curso de nível superior [...] Sem falar no salário insuficiente que faz a gente trabalhar em dois ou mais empregos, aí você tem de 
optar entre ter tempo livre para fazer coisas por você, ou trabalhar e ganhar dinheiro. Muita gente trabalha desmotivado e insatisfeito e aí vive assim, infeliz em casa e consequentemente infeliz no trabalho, são coisas interligadas (Tulipa).

A quarta entrevistada foi Ipê de 35 anos, divorciada e com uma filha. Logo no início da fala a enfermeira citou a carga de trabalho elevada, como fator de maior influência nas suas relações sociais e pessoais. Referiu o trabalho como exaustivo, o que reflete negativamente no seu ânimo para desenvolver atividades de lazer e interações com as pessoas do seu convívio social.

Escolhi a profissão por amor, mas o que mais influencia em minha vida é a carga de trabalho elevada e muito exaustiva e deste modo está diretamente relacionada à qualidade de vida minha e da minha família, pois fico cansada e sem ânimo para lazer e interagir com a comunidade (Ipê).

Quando questionada sobre planos futuros e de que forma o trabalho influencia para a concretização de tais planos, a enfermeira relatou sobre o desejo de investir em seu crescimento profissional, porém afirma que no atual momento não consegue conciliar essa atividade com o trabalho e a vida fraternal por conta da falta de tempo.

Tenho vontade de fazer mestrado, mas para isso teria que abrir mão dos poucos momentos que tenho com minha filha, pois terei que focar bastante nos estudos e já chego em casa cansada e quase não tenho tempo. Estou esperando as condições financeiras melhorarem para que possa diminuir a escala aqui na UTI e assim ter mais tempo livre (Ipê).

A quinta entrevistada foi Orquídea de 45 anos, casada e com um filho. A enfermeira durante a entrevista pontuou vários aspectos que influenciavam nas suas dimensões de vida, desde alimentação até o desgaste mental causado pela falta de insumos.

São vários os fatores que influenciam direta e indiretamente na minha vida fora do trabalho [...] A correria do plantão afeta primeiramente o cansaço físico, depois a alimentação, na falta de tempo eu nunca me alimento do que eu preciso e sim o que é mais prático, afeta também o cansaço mental, porque nunca fazemos tudo o que queremos, sempre 
acaba ficando alguma coisa pendente e isso me frustra [...] Outro fator que influencia indiretamente no meu cansaço mental é a falta de insumos para o paciente, pois interfere no meu trabalho, não consigo realizar minha assistência da forma que eu quero e que é melhor para o paciente, tenho que criar formas alternativas e criativas para substituir o que falta (Orquídea).

A enfermeira finaliza referindo a carga horária de trabalho como o aspecto mais influenciador.

A carga horária da profissão, no momento, é o que mais influencia na minha vida... Por exemplo, trabalhar aos finais de semana impede que eu passe mais tempo com meu filho, que é quando ele tem um maior tempo livre, já que não está estudando (Orquídea).

A sexta entrevistada foi Lírio de 31 anos, solteira. Ao longo da entrevistada Lírio falou sobre vários aspectos que influenciam no manejo da sua vida social. A carga de trabalho e a carga horária foram os dois pontos principais do discurso da enfermeira. Relatou que diante da realidade de trabalho, os cuidados com a saúde mental e física e a manutenção de convívio social satisfatório ficam em segundo plano.

\begin{abstract}
Acontecem várias coisas na minha rotina de trabalho que interferem diretamente na minha vida social. A carga de trabalho é a principal delas, para começar além de todos os cuidados intensivos que temos que ter a um paciente crítico, têm mil papéis para preencher, dar conta de materiais que faltam, corrigir prescrições médicas incompletas, ir atrás de medicação que a farmácia não mandou, tem também as pendências do plantão anterior que a colega não conseguiu cumprir [...] Essas funções acumulativas, para mim, é o maior desencadeador de estresse e cansaço físico, porque o plantão, muitas vezes, é uma correria. E junto de toda essa exaustão mental e física vem a negligência com a alimentação, atividade física, interação social. E para falar logo dessa interação social, a carga horária é o que mais influencia nesse aspecto, porque eu tiro os finais de semana para sair com os amigos, minha família, mas a maioria deles eu tô trabalhando, como eu trabalho pela cooperativa, e só ganho o que trabalho, eu acabo optando por trabalhar para ganhar mais dinheiro (Lírio).
\end{abstract}

Os agentes estressores são aqueles que expõem o profissional a altos níveis de tensão, desestabilizando-o biopsicologicamente. A relação de trabalho, ou seja, relacionamento entre a equipe de enfermagem, quando conflituosa, gera 
estresse no ambiente de trabalho e consequentemente leva a um desequilíbrio emocional. Lírio contempla isso em seu discurso.

Outra coisa que favorece o meu estresse é o relacionamento e a comunicação entre a equipe que muitas vezes é bem difícil, algumas pessoas não querem receber ordens, outras são difíceis de lidar pelo próprio jeito de ser, às vezes faltam até postura ética (Lírio).

Ao longo dos discursos foram pontuados aspectos da rotina de trabalho das enfermeiras que interferem na sua vida pessoal. A partir dos relatos das entrevistadas surgiram categorias temáticas que foram discorridos sobre tais aspectos embasados pela literatura e evidenciado pelas falas.

\section{Categorias}

Os resultados obtidos foram agrupados em categorias temáticas de acordo com aspectos apresentados nos discursos das profissionais durante a entrevista. Emergiram então duas categorias. São elas: cargas de trabalho e condições de trabalho em enfermagem.

\section{Condições de trabalho em enfermagem}

Esta categoria revelou através de discursos, a existência de aspectos associados ao trabalho de enfermagem que interferem nas demais dimensões de vida do profissional, relatando que fatores inerentes do trabalho favorecem ao desgaste físico e mental e prejudicam atividades extralaborais.

As condições de trabalho em enfermagem estão intimamente concatenadas com a qualidade de vida no trabalho e não havendo consenso para tal definição podemos entender a qualidade de vida no trabalho como sendo

um programa que visa facilitar e satisfazer as necessidades do trabalhador ao desenvolver suas atividades na organização, tendo como ideia básica o fato de que as pessoas são mais produtivas quanto mais estiverem satisfeitas e envolvidas com o próprio trabalho (AMARAL; RIBEIRO; PAIXÃO, 2015, p. 67). 
Muitos artigos encontrados na literatura abordam as condições de trabalho em enfermagem como sendo a relação entre o trabalho e a saúde dos trabalhadores de enfermagem. Os autores expõem os principais problemas de saúde que esses trabalhadores devolvem ou podem devolver, são eles: problemas de coluna, doenças do aparelho geniturinário, outros problemas ortopédicos e reumatológicos, doenças infecciosas e parasitárias, hipertensão arterial e acidentes do tipo contusão, entorses e com material perfurocortante.

Segundo Schmoeller et al. (2011), as condições de trabalho da equipe de enfermagem são impróprias e o ambiente é gerador de riscos à saúde. Os autores citam como fatores influenciadores na qualidade da assistência prestada e fatores causadores de sofrimento psíquico, remuneração inadequada, desvalorização social da profissão, relações desarticuladas entre a equipe, tensões inerentes do serviço de saúde, acúmulo de escalas de serviço, entre outros fatores.

Santos e Vandenberghe (2013) discorrem sobre esses mesmos fatores, anteriormente citados, relatando ainda que tais fatores mostrando-se como as principais barreiras para que os profissionais enfermeiros possam atingir satisfatória manutenção da qualidade de vida no trabalho.

Esses fatores são referidos nos discursos das enfermeiras entrevistadas, no qual vimos, anteriormente, nas falas de algumas profissionais, o acúmulo de escalas para compensar a remuneração inadequada, fato que reflete negativamente na vida social e pessoal dessas profissionais, o que fica claro nas falas das entrevistadas quando elas falam da falta de tempo. Algumas até fazem a referência entre trabalhar e não sobrar tempo livre para desenvolver atividades para si.

O desprestígio social da profissão foi citado como fator desmotivador dos trabalhadores atuantes. A comunicação ineficaz foi citada como agente estressor e está diretamente ligada ao favorecimento de um ambiente laboral desgastante. Para Lucas e Passos (2009) a união entre a equipe de enfermagem é importante para promover o equilíbrio psíquico dos trabalhadores e preservar 
um ambiente de trabalho satisfatório, reduzindo danos à saúde mental dos profissionais. Os autores falam ainda que "a difícil relação na equipe dificulta a efetividade do trabalho" (LUCAS; PASSOS, 2009, p. 348).

A qualidade de vida dos indivíduos está interligada com a qualidade de vida no trabalho já que se vive a maior parte da vida trabalhando, além do que, somos indivíduos complexos e ligados ao meio em que vivemos, onde os fatores do trabalho refletem nas outras dimensões de vida e vice e versa.

Diante do exposto vimos que as boas condições de trabalho em enfermagem interferem positivamente nas outras dimensões de vida desses profissionais, pois com um ambiente laboral favorável e fatores satisfatórios inerentes da profissão, os indivíduos sentem-se motivados, satisfeitos, preservando assim as suas saúdes, promovendo bem-estar para si mesmo e juntamente a tudo isso, tem-se um reflexo positivo para a manutenção das relações pessoais e sociais.

Porém, vimos através dos discursos que as más condições de trabalho têm influenciado negativamente a saúde das trabalhadoras e também impedido que elas coordenem, organizem e usufruam da vida social de forma benéfica.

Essas más condições de trabalho vão desde desvalorização da profissão e baixo salário até ambiente laboral satisfatório às doenças, tanto físicas quanto mentais. 


\section{Carga de trabalho}

Esta categoria surgiu devido ao fato de que dentre os aspectos apresentados nos discursos das profissionais existiu aquele que foi mencionado por todas as profissionais. Foi ele: a carga elevada de trabalho.

As cargas de trabalho, segundo Schmoeller et al. (2011), são definidas como sendo elementos do processo de trabalho que interagem com o trabalhador, desencadeando alterações nos processos biopsíquicos, que se manifestam como desgaste físico e psíquico, potenciais ou efetivamente apresentados.

Schmoeller et al. (2011) relatam em seu estudo que a carga de trabalho enquanto "sobrecarga de trabalho" interfere diretamente no processo de desgaste laboral, tendo relação com as condições de trabalho.

Mininel; Baptista e Felli (2011) relatam que, segundo estudos, os trabalhadores de enfermagem estão expostos a várias cargas de trabalho que são geradoras de processos desgastantes, comprometendo consequentemente a qualidade de vida no trabalho.

As cargas de trabalho consistem nas atividades de rotina no ambiente de trabalho. E trazendo para realidade do setor em que as enfermeiras entrevistadas trabalham, alguns autores trazem a UTI como sendo "uma área do setor hospitalar destinada ao cuidado contínuo aos pacientes em situações graves, os quais, além de necessitarem de recursos tecnológicos avançados" (GOULART et al., 2014, p. 347).

Apesar das diferentes conceituações de condições de trabalho e cargas de trabalho, Schmoeller et al. (2011) dizem que as condições de trabalho estão relacionadas às cargas de trabalho (físicas, químicas, biológicas, mecânicas, fisiológicas e psíquicas) a que o profissional está submetido.

Para Schomoellet et al. (2011), as cargas físicas são derivadas principalmente das exigências técnicas para a transformação do objeto de trabalho e caracterizam um determinado ambiente de trabalho, com o qual o trabalhador interage cotidianamente. As cargas químicas derivam principalmente do ambiente de trabalho e sua interação cotidiana com o 
trabalhador. Ainda são derivadas do objeto de trabalho e das condições de higiene ambiental as cargas orgânicas, que incluem qualquer organismo animal ou vegetal que possa determinar danos à saúde do trabalhador. Já as cargas mecânicas são derivadas principalmente da tecnologia, devido a sua operação ou manutenção.

Em relação às cargas fisiológicas e psíquicas, as primeiras são oriundas das diversas maneiras de se realizar as atividades e estão constituídas por elementos como esforço físico ou visual, deslocamentos e movimentos exigidos pelas tarefas, espaço de trabalho disponível, posições assumidas em sua execução, horas extras ou intensificação do trabalho, jornadas prolongadas e turnos noturnos e rotativos. Já as cargas psíquicas estão relacionadas ao objeto de trabalho - ser humano que sofre, sente dor e morre, e está envolvido em situações geradoras de estresse, fadiga, tensão (MININEL; BAPTISTA; FELLI, 2011).

Os pacientes internados na UTI são particularmente críticos e necessitam de cuidados clínicos específicos. Essa condição do paciente tem influência sob os profissionais, pois estes precisam estar mais atentados, de modo que sofrem maior pressão por conta dos cuidados que devem ser prestados, o que fica evidenciado nas falas de algumas profissionais.

Segundo Chaves; Laus e Camelo (2012), os enfermeiros são responsáveis pela gerência do cuidado que envolve diagnóstico, planejamento, execução e avaliação, também coordena e supervisiona a equipe de enfermagem e somado a isto gerencia o controle de recursos materiais e humanos.

Diante do fato de que os pacientes da UTI necessitam de cuidados complexos e o enfermeiro além de aplicar esses cuidados precisa também gerenciar a unidade, tal realidade está sobrecarregando os enfermeiros, pois somado a carga psíquica gerada pela responsabilidade de lidar com pacientes críticos, estão as questões de cuidado indireto que são as burocracias em geral.

As cargas de trabalho podem ser geradoras de desgaste físico, mental e emocional. Os profissionais quando desgastados e exauridos por conta das altas cargas de trabalho deixam de cuidar de si e das relações com as pessoas do seu convívio. Vimos durante os discursos a dificuldade encontrada pelas 
profissionais em conciliar o trabalho e a vida extralaboral, colocando em segundo plano o cuidado pessoal, espiritual, deixando de lado atividades de lazer e interação social.

\section{Considerações Finais}

A presente pesquisa possibilitou a identificação dos componentes da dimensão profissional que interferem no bem-estar e qualidade de vida dos enfermeiros. Os componentes foram discorridos nos discursos das enfermeiras entrevistadas, onde a maioria delas abordaram os mesmos fatores.

A enfermagem possui características históricas que estão preservadas até a atualidade, a dedicação, doação e abnegação ainda estão presentes na profissão. Essas características históricas refletem nas condições de trabalho em enfermagem que se mostram como favorecedoras de desgastes e adoecimento do enfermeiro. As condições adversas pelas quais a profissão enfrenta, obriga os profissionais a se submeterem a situações desfavoráveis a sua saúde.

Aspectos evidenciados nas falas mostram que a remuneração inadequada leva ao acumulo de trabalho, que o desprestigio social leva a desmotivação profissional, que as relações desarticuladas no ambiente de trabalho levam ao adoecimento psíquico dos trabalhadores e com todos esses fatores presentes na vida profissional desses indivíduos, temos a reflexão negativa da outras dimensões de vida desses profissionais, pois ao passo de que esses profissionais não se encontram satisfeitos no seu ambiente de trabalho, os mesmos não conseguem conduzir a vida extralaboral de forma adequada. Algumas enfermeiras mostram em seus discursos que não conseguem conciliar trabalho e vida social.

A pesquisa possibilitou identificar as cargas de trabalho e como estas interferem de forma negativa na manutenção do bem-estar e qualidade de vida do enfermeiro. Os enfermeiros sendo os cuidadores mais próximos ao paciente estão expostos as angústias, ansiedades e medos que estão ligados ao processo 
de doença do paciente e, além disso, das situações limites e a responsabilidade em prestar cuidados a pacientes críticos, são atribuídas a esses profissionais atividades burocráticas, controle de recursos humanos e materiais, supervisão e orientação da equipe de enfermagem.

O acúmulo de funções, exposição a altas cargas de trabalho e a má condição de trabalho desfavorece as relações pessoais e sociais, descanso adequado, preservação das saúdes física, emocional, mental, espiritual e social, visto que a má qualidade de vida no trabalho está concatenada com a baixa qualidade de vida dos enfermeiros.

Faz-se necessário que os enfermeiros repensem suas atividades, conheçam a si mesmos, façam uma autoavaliação para que possam identificar o que lhes dar prazer e o lhes desestimulam assumindo assim um perfil favorável, buscando crescimento profissional, boa interação social, buscando desenvolver atividades que favoreça o seu bem-estar e preserve sua saúde, deixando que os processos protetores ultrapassem os processos destrutivos tendo assim um favorecimento à vida. 


\section{Referências}

AMARAL, Juliana Ferri do; RIBEIRO, Juliane Portella; PAIXÃO, Dilmar Xavier da. Qualidade de vida no trabalho dos profissionais de enfermagem em ambiente hospitalar: uma revisão integrativa. Revista Espaço para a Saúde, Londrina, v. 16, n. 1, p. 66-74, jan./mar. 2015.

BRASIL. Resolução $n^{\circ}$ 466, de 12 de dezembro de 2012. Diretrizes e Normas Regulamentadoras de Pesquisas Envolvendo Seres Humanos. Diário Oficial da União: seção 1, Brasília, DF, 13 jun. 2013. Disponível em:

https://www.inca.gov.br/publicacoes/legislacao/resolucao-cns-466\%2012\#: :text=Aprova $\% 20$ as $\%$ 20diretrizes $\% 20 \mathrm{e} \%$ 20normas,revoga $\% 20$ as $\% 20 \mathrm{R}$ esolu\%C3\%20\%A7\%C3\%B5es\%20CNS\%20nos. Acesso em: 19 jul. 2021.

CHAVES, Lucieli Dias Pedrichi; LAUS, Ana Maria; CAMELO, Sílvia Henriques. Ações gerenciais e assistenciais do enfermeiro em unidade de terapia intensiva. Revista Eletrônica de Enfermagem, São Paulo, v. 3, n. 14, p. 671-678, jul. 2012.

ELIAS, Marisa Aparecida; NAVARRO, Vera Lúcia. A relação entre o trabalho, a saúde e as condições de vida: negatividade e positividade no trabalho das profissionais de enfermagem de um hospital escola. Revista Latino-Americana de Enfermagem, São Paulo, v. 14, n. 4, p. 517-525, jul./ago. 2006.

GIL, Antonio Carlos. Métodos e técnicas de pesquisa social. 5. ed. São Paulo: Atlas, 2008.

GOULART, Luana Loppi et al. Carga de trabalho de enfermagem em uma unidade de terapia intensiva de trauma. Revista Eletrônica de Enfermagem, v. 16, n. 2, p. 346-351, abr./jun. 2014. Disponível em: https://www.revistas.ufg.br/fen/article/view/22922. Acesso em: 27 ago. 2021.

KRUSE, Maria Henriqueta Luce. Enfermagem moderna: a ordem do cuidado. Revista Brasileira de Enfermagem, v. 59, p. 403-410, 2006. Número especial.

LUCAS, Janaína Silva; PASSOS, Joanir Pereira. O estresse no trabalho da equipe de enfermagem em unidade de terapia intensiva. Revista de Pesquisa Cuidado é Fundamental Online, v. 1, n. 2, p. 345-352, set./ dez. 2009. Disponível em: http://www.seer.unirio.br/index.php/cuidadofundamental/article/view/411 . Acesso em: 27 ago. 2021.

MAY, Tim. Pesquisa social: questões, métodos e processos. Tradução: Carlos Alberto Silveira Netto Soares. 3. ed. Porto Alegre: Artmed, 2004. 
MINAYO, Maria Cecília de Souza (org.). Pesquisa social: teoria, método e criatividade. 18. ed. Petrópolis: Vozes, 2013.

MININEL, Vivian Aline; BAPTISTA, Patrícia Campos Pavan; FELLI, Vanda Elisa Andres. Cargas psíquicas e processos de desgaste em trabalhadores de enfermagem de hospitais universitários brasileiros. Revista Latino-Americana de Enfermagem, São Paulo, v. 2, n. 19, p. 3-9, mar./abr. 2011.

RAMOS, Érika Lima et al. Qualidade de vida no trabalho: repercussões para a saúde do trabalhador de enfermagem de terapia intensiva. Revista Pesquisa Cuidado é Fundamental, Rio de Janeiro, v. 6, n. 2, p. 571-583, abr./jun. 2014.

SANTOS, Débora Aparecida da Silva; VANDENBERGHE, Luc. Atuação profissional e bem-estar em enfermeiros. Revista de Enfermagem da UFSM, Santa Maria, v. 3, n. 1, p. 26-34, jan./abr. 2013.

SCHMOELLER, Roseli et al. Cargas de trabalho e condições de trabalho da enfermagem: revisão integrativa. Revista Gaúcha de Enfermagem, Porto Alegre, v. 32, n. 2, p. 368-377, jun. 2011.

SILVA, Rosângela Marion da et al. Análise quantitativa da satisfação profissional dos enfermeiros que atuam no período noturno. Texto \& Contexto Enfermagem, Florianópolis, v. 18, n. 2, p. 298-305, abr./jun. 2009. 


\section{5}

Envelhecimento na pósmodernidade: 0 que a psicologia tem a ver com isso? 


\title{
5 ENVELHECIMENTO NA PÓS- MODERNIDADE: O QUE A PSICOLOGIA TEM A VER COM ISSO?
}

\author{
Ticyane Candeia Ribeiro Sousa Olímpio \\ Fernando Antonio Carvalho Costa \\ Selene Regina Mazza \\ Daniele Vasconcelos Fernandes Vieira \\ Terezinha Almeida Queiroz
}

\section{Resumo}

Introdução: Este artigo apresenta uma reflexão sobre o lugar do idoso no contexto da pós-modernidade, mostrando uma nova percepção sobre o processo de envelhecimento diante das mais diversas evoluções dentro da sociedade moderna, apontando qual o papel da Psicologia dentro deste contexto. Objetivo: Apresentar como se processa o envelhecer e de que maneira se desenvolve na percepção subjetiva e social, identificar as perspectivas e os desafios que são apresentados pela pós-modernidade e apontar aspectos relevantes sobre a nova concepção do envelhecimento e a atuação da Psicologia no atual contexto. Método: $O$ artigo foi elaborado por meio de uma pesquisa de revisão de literatura, de cunho narrativo, com caráter exploratório, utilizando-se da abordagem qualitativa. Resultados: Constatamos que o indivíduo geralmente não sabe lidar com os "polos referenciais" da existência e aqui nos referimos tanto a infância quanto a velhice. Tendo como referência o envelhecer, o olhar que o sujeito possui de si mesmo e do seu lugar com as necessárias adaptações tornase decisivo para a vivência de uma "nova velhice". Vivemos inegavelmente em um momento privilegiado e, ao mesmo tempo, desafiador da história, uma vez que essa fase está estritamente ligada à ação humana e experimenta um movimento de irreversibilidade, ou seja; o tempo não para nunca. A percepção da pessoa que envelhece num contexto de hipermodernidade se confronta entre a melancolia saudosista do que foi vivido e a provocação contínua e urgente de uma adaptação aos vários estímulos presentes. Conclusão: Conclui-se que os desafios deste cenário submetem o envelhecimento à necessidade da contínua construção do sujeito idoso como ser ativo diante do seu próprio processo. Considerando a relevância do tema, torna-se importante um estudo mais aprofundado e crítico.

Palavras-chave: Envelhecimento. Pós-Modernidade. Psicologia. 


\section{Introdução}

O presente artigo surgiu a partir do interesse sobre a temática do processo de envelhecimento do sujeito, que deve ser analisado como um ser total e percebido para além do seu atual momento no desenvolvimento humano. Dentro dessa perspectiva, o sujeito envelhecido não se constitui significativamente por meio do avanço da sua faixa etária, mas por meio da contínua metamorfose durante o seu processo como ser humano (DEBERT, 1999).

O processo do envelhecer é constituído de diversos contextos. No decorrer dos estudos, percebemos que esse indivíduo é constituído de demandas pessoais e sociais, além das questões fisiológicas, que, por muitas vezes, se torna o foco principal de preocupação. Assim, buscamos nos referir a esse momento sobre um ponto que está vinculado ao psicológico: a questão do olhar que o velho possui sobre o próprio processo de se tornar um sujeito envelhecido.

Para investigar o assunto, é relevante ampliar a visão a fim de perceber em que instante o olhar de pertença a tal etapa da vida é do próprio sujeito que envelhece e em que ponto entra o olhar do outro, uma vez que o outro não apenas olha, mas também comunica sobre esse ser.

Por conseguinte, a pós-modernidade vem trazendo recorrentes transfigurações ao conduzir a sociedade moderna para o despertar de uma urgência em se reconstruir em uma nova configuração de mundo, no qual ocorrem rompimentos com práticas antigas e introdução de novos costumes, valores, culturas e mudanças nas relações humanas. Neste lugar, tudo acontece de forma constante e o ser humano vem sendo sufocado com informações novas a cada segundo. Giddens (2002) expõe que a modernidade vem com o objetivo de modificar a constituição natural da vida social do cotidiano e prejudicar questões consideradas pessoais da existência do ser humano.

Na sociedade atual, devido à modernização recorrente, há uma complexidade em seguir uma ordem de compreensão de como o envelhecimento ocorre nos dias atuais, visto que o sujeito e o mundo se constituem em um 
movimento de metamorfose, passando por evoluções. Além disso, e não é mais possível dar conta das inúmeras mudanças que já se estabeleceram, porque não há mais tempo para pensar sobre o processo que aconteceu e irá acontecer devido à quantidade de informações presentes no nosso dia a dia, e assim também ocorre com o olhar sobre o envelhecimento.

Vista como uma nova era, a pós-modernidade começa a ser considerada a transformação radical da modernidade, trazendo novas ideias e olhares sobre as modificações na forma de viver, o que faz o olhar se voltar para o mundo da informação, no qual o conhecimento torna-se papel fundamental para o sujeito ser reconhecido. É assim que as informações prévias tomam o espaço das tradições que perduraram tantas épocas, que na era atual são consideradas uma prisão ou liberdade.

Em busca pela compreensão dessa nova constituição do olhar sobre o envelhecimento na nova sociedade que está se constituindo, interessa-nos a posição da Psicologia diante da pós-modernidade, mais precisamente sobre as mudanças que a pós-modernidade gerou na nossa sociedade e as percepções sociais na compreensão do envelhecer.

Diante da explanação inicial sobre as temáticas, a questão primordial a ser respondida é se na presença das mais diversas evoluções que o mundo está propondo para a sociedade, o olhar sobre o envelhecimento ainda se constitui na mesma perspectiva de eras passadas ou ocorreram mudanças que reconstruíram completamente a visão sobre essa etapa da vida? Como a Psicologia percebe isso?

\section{Objetivo}

Apresentar como se processa o envelhecer e de que maneira se desenvolve na percepção subjetiva e social, identificar as perspectivas e os desafios que são apresentados pela pós-modernidade e apontar aspectos relevantes sobre a nova concepção do envelhecimento e a atuação da Psicologia no atual contexto. 


\section{Metodologia}

O presente artigo foi elaborado através de uma pesquisa de revisão de literatura, de cunho narrativo, com caráter exploratório, utilizando-se da abordagem qualitativa e de natureza básica.

A revisão de literatura foi realizada através de materiais impressos publicados e disponibilizados na Internet (GIL, 2010). A pesquisa tem cunho narrativo e crítico, no qual são apresentadas publicações que discutem e descrevem teoricamente o assunto. Possui caráter exploratório, com o objetivo de acrescentar conhecimentos na área referente ao envelhecimento na pósmodernidade, buscando proporcionar novas visões sobre a atual realidade desta temática, tornando o assunto mais compreensível (GIL, 2010).

A pesquisa pretende oferecer conhecimento em três perspectivas ou eixos os quais consideramos relevantes: a sociedade, tendo em vista propiciar saberes e percepções acerca do envelhecimento na era da pós-modernidade. A Psicologia, oferecendo uma aproximação necessária do tema a fim de que a percepção do envelhecimento e sua relação com o período pós-moderno seja assimilado de forma mais criativa. E, por fim, cada um de nós, que nos deparamos com um tema apaixonante e desafiador.

Foram utilizadas referências, na sua grande maioria, de livros considerados relevantes sobre as duas temáticas abordadas, sendo visto que os autores utilizados possuem destaque na maioria dos artigos referenciados. Esse material foi retirado das plataformas do SciELO e Pepsic, utilizando os descritores envelhecimento; envelhecer; idoso. Todos foram selecionados a partir do critério de publicação abrangendo os anos de 2010 a 2018. 


\title{
Resultados e Discussão
}

\author{
Envelhecimento
}

\section{O sujeito em processo de envelhecer}

Estamos vivenciando um aumento da expectativa de vida das pessoas e, consequentemente, uma significativa presença na população de pessoas em idade mais avançada. Entretanto, o que realmente isso significa? O que é envelhecer? O que esse tempo da velhice representa para nós? Que imagem é possível elaborar quando o assunto é o envelhecimento?

A vida de cada ser humano é composta de fases, todo sujeito passa por processos no decorrer desse processo. Cada estação é formada por características e desenvolvimentos específicos que demarcam uma determinada fase. Destacaremos a fase do envelhecimento.

O envelhecimento é demarcado por características próprias, ou seja; o sujeito começa a ser considerado velho a partir dos estágios que assume esses tais aspectos, sendo eles universais (atributos que todo ser envelhecido possui) e probabilísticos (traços que podem ou não aparecer). Apesar de todos os aspectos caracterizantes, alguns aparecendo com maior evidência e outras não, o sujeito em processo de envelhecimento pode ser visto a partir de diferentes perspectivas tais como as idades cronológica, social e biológica, nas quais o sujeito é encaixado em um aspecto que o torna diretamente associado àquela fase de vida. A idade cronológica vem a ser apenas a medição do quanto a pessoa é velha; a idade social está diretamente relacionada a questões comportamentais de acordo com a idade cronológica, atendendo expectativas da sociedade e por fim, a idade biológica se volta para aspectos corporais (STUART-HAMILTON, 2002).

Apesar de conter essas análises de como ver o sujeito em processo de envelhecimento, boa parte dos estudos se voltam para os aspectos da idade cronológica, apresentando o velho apenas como um ser carregado e constituído primordialmente por questões biológicas. Papalia e Olds (2000) relatam que os 
velhos são divididos por faixas etárias. Entre 65 e 74 anos, eles estão no segmento funcional, considerados assim idosos jovens, já aqueles entre as idades de 75 e 84 anos são classificados como "idoso"1 e, por fim, os sujeitos que apresentam precariedade, mais predispostos ao acometimento de doenças e com dificuldades em conduzir atividades rotineiras, são classificados como idosos mais velhos, tendo 85 anos ou mais.

O nosso olhar sobre o envelhecimento não deve ser demarcado apenas por estas divisões impostas pela sociedade. A estrutura pode não ter intenção de reduzir os sujeitos e enquadrá-los em estágios de envelhecimento, mas produzem esse efeito, colocando-os em uma análise contextual única, o se tornar e ser velho.

Velhice, no nosso entender, deve ser considerada como uma fase do desenvolvimento humano, não redutível apenas à ótica simplista que a coloca, exclusivamente, como um período de perdas e incapacidades. Mais do que isso, acreditamos que o envelhecimento ganha o estatuto de um processo de vida, marcado por mudanças biopsicossociais específicas (ROSA; VILHENA, 2016, p. 11).

De acordo com o argumento acima, o envelhecimento deve ser percebido como uma fase de mudanças em diversos contextos, elaborações e reelaborações feitas pelo próprio sujeito sobre si mesmo e tudo o que o rodeia, apresentando um ser que foi se construindo a partir dos mais diversos aspectos do passado e presente. O velho é constituído de histórias, experiências, relações sociais, não sendo um ser acumulador de tudo isso, mas alguém que faz parte do conjunto, um ser ativo no processo.

Domingues (2014) destaca que quando o ser oculta suas experiências vividas, ele mesmo retira as próprias contribuições para a sociedade. Assim, o envelhecimento é demarcado por uma vida repleta de sentidos e significados elaborados no contexto social. O sujeito envelhecido traz consigo a história, apresentando-se como narrador principal da sua trajetória no decorrer do tempo e de percursos repletos de conteúdo sobre as mudanças sociais e do mundo.

\footnotetext{
${ }^{1}$ Este termo faz referência à faixa mais avançada dos que já se encontram na idade idosa.
} 
O envelhecimento passou por um processo de diversas alterações históricas para chegar à visão que temos atualmente sobre ele. Foram necessárias muitas etapas e divisões no decorrer da história da sociedade que sucederam mudanças para o desenvolvimento histórico do olhar sobre o processo de envelhecimento em diversos contextos, principalmente no social.

Em relação aos períodos que marcaram a evolução do envelhecimento, Debert (1999) apresenta que esse processo ocorreu em três períodos. Primeiramente, de 1945 a 1960, o velho esteve diretamente relacionado a um sujeito que se encontra em uma situação de pobreza, forçando o sistema da aposentadoria a oferecer melhores condições, colocando-o como sujeito diferenciado dos demais que possuem assistência. Posteriormente, no período entre 1959 a 1967, ocorre a mudança do velho pobre para o velho solitário; uma vítima da exclusão social. Assim políticas de lazer e serviços especializados de saúde para a melhora do estilo de vida desse público passaram a existir. Por fim, o terceiro período é classificado pela era da pré-aposentadoria, que visa a utilização dos direitos da aposentadoria a partir da idade cronológica, sendo o período em que existe a proibição do trabalho. A partir deste ocorrido, no terceiro período do envelhecimento, surgem leis e direitos que apresentaram ao velho uma definição concreta do seu espaço dentro da sociedade.

A partir daí, Debert (1999) propõe que o sujeito envelhecido mudou sua imagem de indivíduo abandonado e vitimizado com necessidades econômicas supridas pelo Estado para a ideia de um velho com atuação política ativa na produção de conhecimentos sobre o seu desenvolvimento, um sujeito presente nos debates sobre as políticas públicas que foram criadas especificamente para os velhos.

Apesar das evoluções na representação e classificação do velho dentro do contexto social, para que ele possa ganhar espaço, se torna relevante ressaltar que é necessário que o sujeito velho seja visto como ser ativo, a fim de alcançar um envelhecimento "bem-sucedido". É fundamental o contexto em que o velho está inserido socialmente e economicamente para realizar isso. 
Nesta conjuntura, observando a velhice como um período que possui inúmeras possibilidades de enfrentamento de questões que vão aparecer no decorrer dessa fase, Guerra e Caldas (2010) apontam que no estágio de envelhecimento existem dificuldades (doenças, demências, degenerações, exclusão dos prazeres, abandono, tristeza, proximidade da morte, incapacidades, aposentadoria) e recompensas (experiências, participação dos grupos extrafamiliares, fila preferencial, independência, integração), mas cabe ressaltar que qualquer uma destas características depende do contexto no qual o sujeito está diretamente inserido.

Guerra e Caldas (2010) ainda assinalam que é indispensável analisar onde o sujeito está inserido (grupos sociais), observando sua condição socioeconômica, qual cultura está adentrado, se há envolvimento com religião e atividades que são ou poderiam ser elaboradas dentro da comunidade que está introduzido. A soma desse cenário que perpassa o sujeito é diretamente relacionada ao enfretamento de dificuldades dentro de cada enquadramento desses apresentados acima. Para que haja uma análise do processo de envelhecimento dentro da sua própria história de vida, torna-se necessário apresentar suporte e significação a essa nova fase de desenvolvimento, com aspectos bases que fundamentam sua identidade como ser ativo na própria construção como sujeito.

Portanto, pode-se compreender que o caminho de reelaboração é feito em conjunto. Primeiro, o velho precisa tornar-se ativo e presente, segundo o contexto social diz muito sobre como o envelhecimento irá ser conduzido, terceiro, apesar das mudanças que sobre a elaboração do sujeito nessa nova fase, novos olhares para esse estágio se apresentam. Entraremos nessas questões, porém visando buscar uma compreensão mais profunda sobre as visões nesse processo. 


\section{Olhar para si e o olhar do outro}

Durante o processo de envelhecer tornar-se necessário discutirmos a questão mais conflitante quando o assunto é envelhecimento, que é a apresentação do olhar para si (do próprio sujeito que envelhece) e o olhar do outro (sociedade), buscando compreender como as duas visões que, primeiramente, parecem tão distintas, mas se vinculam nos estudos sobre o reconhecimento e representatividade do envelhecimento na sociedade.

Para investigar a questão, é relevante ampliar a visão a fim de perceber em que instante o olhar de pertencer a essa etapa da vida é do próprio sujeito que envelhece e em que ponto entra o olhar do outro que, por sua vez, não apenas observa o outro envelhecendo, mas também fala sobre esse ser. Para Rosa e Vilhena (2016), apesar dos dois pontos de vista, o envelhecimento começa a aparecer mais precisamente para os outros do que para o próprio sujeito envelhecido. Já Giddens acredita que:

\footnotetext{
A questão existencial da auto-identidade está mesclada com a natureza frágil da biografia que o indivíduo "fornece" de si mesmo. A identidade de uma pessoa não se encontra no comportamento nem - por mais importante que seja - nas reações dos outros, mas na capacidade de manter em andamento uma narrativa particular (GIDDENS, 2002, p. $55-56)$.
}

Neste contexto, há uma percepção de que o envelhecimento vem carregado de discursos sociais que acometem o sujeito de uma forma completa. Por algumas vezes, somente os discursos são relevantes quando o assunto é envelhecer, ausentando ou menosprezando o próprio olhar do sujeito sobre si.

Tais representações permeiam a população idosa e promovem uma ideia equivocada de alguém disfuncional, passivo diante da vida e muito próximo da finitude. É necessário romper com a compreensão paradigmática na qual a velhice configura-se como o fim do desenvolvimento. Mesmo levando em consideração o que ocorre diante da senilidade, como o surgimento de doenças associadas à idade cronológica, tais alterações não são mais fatores principais 
para o declínio da condição do envelhecer. É necessário também nos afixar ao contexto de inserção ou vivência do indivíduo nas mais variadas e distintas relações constitutivas.

Rosa e Vilhena (2016) discorrem que não há possibilidade de uma significação do envelhecimento sem que exista a presença da representação social e a rejeição sobre essa fase da vida que é tão simbólica por se declarar sendo o último estágio do ser. Por meio disso, há um diálogo direto entre o que é subjetivo e o que é trazido pela sociedade sobre envelhecimento, tornando-se um diálogo fundamental para compreensão desta visão.

\begin{abstract}
A imagem sublimada deles mesmos que lhe é proposta é a do sábio aureolado de cabelos brancos, rico de experiência e venerável, que domina de muito alto a condição humana, se dela se afasta, caem no outro extremo: a imagem que se opõe a primeira é a do velho louco que caduca e delira e de quem as crianças zombam. De qualquer maneira, por sua virtude ou por sua abjeção, os velhos situam-se fora da humanidade. Pode-se portanto, sem escrúpulo, recusar-lhes o mínimo julgado necessário para levar uma vida de homem (BEAUVOIR, 1990, p. 10).
\end{abstract}

Quando o ser envelhece, surge a sensação no próprio sujeito de finitude, o receio da ausência, da morte vista como um momento de fracasso, da não capacidade, das perdas, do corpo que começa a apresentar decaimentos.

Beavouir (1990) acredita que a velhice é um momento difícil de ser assumido devido a uma crise de identificação, na qual o sujeito continua sendo o mesmo, porém transformado em outro ser, em outro corpo. Durante tal decurso, é necessário que haja a construção de uma nova imagem de si para a ressignificação da vida. É no decorrer dessa construção da nova imagem de si que chega o olhar do outro, pois a velhice se procede primeiro a partir desse olhar para o velho, como o olhar da sociedade, que quer sugerir ao sujeito que ele envelheça da forma como é apresentado a ele. Neste contexto, Guerra e Caldas (2010, p. 2932) afirmam que:

A velhice é muito associada à decadência, e não apenas a desgaste e decadência física, mas também à doença, dependência e "fealdade". $\mathrm{O}$ idoso, no contexto da mídia, é apresentado como "problema" e 
apontado sob o olhar do outro, sendo desconsiderada a sua opinião quanto ao momento que vive dentro do processo de envelhecimento e suas vivências e evidências a respeito de si mesmo, tornando-se evidente descarte da sua autopercepção como indivíduo nesse processo.

Importante destacarmos que cada idoso possui uma percepção sui generis do próprio processo de envelhecer, tendo como ponto de referência inicialmente a maneira pela qual as modificações ocorrem no campo organismo/meio, desencadeando ou não preocupações de como envelhecer pode ser sofrido ou satisfatório.

Uma vez que somos marcados decisivamente pelo caráter biopsicossocial, esse permite a percepção da complexidade do envelhecimento enquanto dinâmico e singular, então consideramos que os indivíduos não envelhecem todos da mesma forma, assim como cada existência é marcada pela singularidade própria, o envelhecer carrega consigo traços distintos.

Desde uma visão a partir de si mesmo, como também pela maneira como o idoso é percebido pelos mais próximos no contexto social, sob os mais variados ângulos existe um processo de esmaecimento da identidade e valor fundamental como pessoa com a agregação das mais variadas visões preconceituosas e, geralmente, depreciativas.

As diferentes modalidades de preconceito se expressam em várias atitudes do cotidiano, como a exclusão social, o apagamento subjetivo, o desinteresse pela história de vida e o medo do contato com a velhice devido à sua estreita vinculação com a figura da morte (ROSA; VILHENA, 2016, p. 12).

$\mathrm{O}$ ato de envelhecer, assim o entendemos, deve acolher $\mathrm{o}$ envelhecimento como processo totalizante, e não segmentado da existência, além de dar uma oportunidade para o indivíduo reelaborar as relações pessoal, temporal, hodierna e histórica, todas em processo de novos significados.

Entendemos que a velhice possui uma introjeção dentro do contexto da sociedade de consumo que perpetua a imagem do ser a partir de um logos mercadológico, ou seja; "consumo, logo existo", mesmo diante de um horizonte 
mais alargado de movimentação nas distintas esferas sociais, em que o mercado oferta produtos e serviços específicos para cada público. O Estado de direito promulga leis e estatutos, a ciência investiga e avança mais por meio da geriatria e gerontologia, mesmo assim ainda parece existir uma gama de visões deturpadas e geralmente preconceituosas que mais acentuam uma concepção depreciativa e decrépita do idoso.

\section{Modernidade e pós-modernidade: desafios e perspectivas}

Antes da pós-modernidade ser instituída como a era atual da sociedade, aconteceram diversas mudanças históricas. Durante o processo de constituição da modernidade, foi necessário realizar divisões. Assim, para Lipovetsky et al. (2005), a primeira modernidade tinha preocupações políticas, uma vez que praticamente tudo girava em torno da polarização entre esquerda e direita, quem defendia o socialismo, liberalismo, comunismo, entre outros. A segunda modernidade foi apresentada como a era da clonagem, recursos começam a ser utilizados visando a transformação da vida, tornando-se a era das biotecnologias e da comunicação. O futuro seria então focado na democracia e no mercado.

Antigamente, o mundo girava em torno do capitalismo constituído por meio da produção ativa, porém a modernidade alterou o eixo de comando, trazendo o industrialismo, que se utiliza de maquinários para a produção, não apenas se prendendo a atividade manual como principal forma dos seres humanos interagirem com o novo mundo que estava se transformando. Giddens (1991) apresenta o industrialismo na modernidade, unindo-se a duas fortes vertentes, a tecnologia e a ciência, com as quais o homem começa a viver em um ambiente físico, mas que não apresenta mais o aspecto natural ou vivencial dos contextos passados.

Apesar da modernidade ter sido constituída em duas vertentes (pré e pós), sempre apresentou um só nome, indicando que diante de tantas mudanças que ocorreram no decorrer das eras, a modernidade ainda é uma só. Lipovetsky 
(2005) expõe que o modernismo é um período que move os seres humanos a produzirem de forma sucessiva, sem parar, buscando sempre o adiante. Em todo o processo, o ideal sempre foi seguir para o próximo momento, em constante evolução. $\mathrm{O}$ autor também salienta que:

\footnotetext{
O modernismo não é uma ruptura primeira e incomparável: Na fúria de destruir a tradição e inovar radicalmente, o modernismo prossegue na ordem cultural, com um século de intervalo, a obra própria das sociedades modernas visando se instituir na forma democrática. $\mathrm{O}$ modernismo não é mais do que uma face do vasto processo secular que conduz ao surgimento das sociedades democráticas baseadas na soberania do indivíduo e do povo, do domínio da tradição (LIPOVETSKY, 2005, p. 66).
}

De acordo com o exposto, percebemos que aparece muito presente, no fenômeno da modernidade, a compreensão de uma ruptura radical da temporalidade, uma vez que não está mais no passado o lugar da felicidade, nem tampouco no presente vivido, mas sim no futuro, sendo visto por uma perspectiva vindoura de algo melhor, de uma vida mais facilitada e isenta o máximo possível das preocupações e até dos sofrimentos, como se não houvesse o direito de perder, sofrer e sentir dor. Em contrapartida, na pós-modernidade, tais aspectos são simplesmente suprimidos da vida humana que está mais voltada para o sucesso, a riqueza e a prosperidade, inclusive e de preferência exposta nas redes sociais.

Estamos diante de um enorme divisor de águas, na história da humanidade, na qual se consolida o discurso efetivo e radicalmente oposto a essa decadência. Aqui, são exaltadas as conquistas, a capacidade analítica de compreensão e até a explicação de todas as realidades humanas e a satisfação dos anseios mais profundos da nossa existência, tudo o que nos torna herdeiros de uma panaceia do domínio da razão. "A razão poderia reinar sobre o mundo e criar as condições para a paz, a equidade e a justiça" (LIPOVETSKY, 2007, p. 14).

Isso porque a crítica que se apresenta para o ideal pós-moderno de uma "iluminação" redentora da vida humana não se concretizou, pelo contrário, causou uma alienação da pessoa no seu sentido mais decisivo e profundo de sua 
existência como também a compreensão da vida humana a partir da predominância do tecnicismo e do liberalismo comercial, em que tudo parece estar subjugado a essas duas estruturas totêmicas de composição e organização vital:

\begin{abstract}
A modernidade não apenas conseguiu concretizar os ideais das Luzes que objetivava alcançar, mas também, ao invés de avalizar um trabalho de real libertação, deu lugar a um empreendimento de verdadeira subjugação, burocrática e disciplinar, exercendo-se igualmente sobre os corpos e os espíritos (LIPOVETSKY, 2007, p. 16).
\end{abstract}

Assim, constatamos a enorme influência a qual em sua maioria tornase um pesado fardo na vida das pessoas que deverão corresponder tanto na dimensão corpórea quanto na dimensão espiritual mais profunda aos ditames propostos como padrões para o corpo e até para a maneira de crer, uma verdadeira tirania alienante e degradadora da condição de possibilidade do existir enquanto pessoa.

Temos a configuração de uma sociedade calcada em modelos fluidos de controle da subjetividade, em prazeres descartáveis, em relações passageiras e obsoletas. Falamos então, de uma sociedade fluida que se caracteriza pela descentralização, pela invisibilidade e pela onipresença e que implica um modo de controle do tempo, do corpo e da vida. Vida que, por seu caráter trágico, comporta a angústia (DANTAS, 2011, p. $34)$.

Torna-se notório uma peculiar elaboração da personalização individual e dos controles exercidos sobre a pessoa e sua liberdade na tentativa de compreensão da dinâmica individualista originária com a modernidade. Tal acentuação individual passou a ser a pedra de toque fundamental, contrapondo os valores das tradições e instituições vigentes e atuantes como valor de verdade na qual se constrói a vida.

Outro aspecto marcante é a acentuada presença de paradoxos, pois ora a sociedade está orientada por controles os mais diversos possíveis, ora existe uma exacerbada permissividade presente inclusive com as devidas manifestações patológicas, por exemplo, somos a sociedade da busca pelo corpo 
perfeito, seguindo determinados padrões de magreza, em alguns casos manifesta-se os distúrbios alimentares, percebendo assim a existência de uma lógica paradoxal.

Uma sociedade que se encontra diante de diversas formas de existência, que exige mudanças e posicionamentos no viver e agir de forma cada vez mais automatizada, ausentando-se por muitas vezes de pensamentos reflexivos sobre como existir subjetivamente, apegando-se ao que a sociedade impõe como moda e cultura.

Segundo Dantas (2011), o sistema em que vivemos está voltado apenas para consumação e atuação que é realizada no dia a dia, focando na cultura da satisfação do eu no contexto atual (aqui e agora) e na valorização da autoimagem, gerando assim uma vida sem objetivos, sem planos, que é vivida de forma superficial e sem um fim subjetivo. Então, consequentemente, estamos nos tornamos a sociedade que age pela ação constante de autorregulação momentânea, não gerando o contato com o real das experiências. Para o autor, “o indivíduo encontra-se mergulhado em insegurança e medos da perda do controle de sua vida, busca cauterizações para os seus sofrimentos ou modos de ser que não se encaixam, da maneira prevista, ao panorama atual" (DANTAS, 2011, p. 46).

A pós-modernidade também é considerada a era do conhecimento que levou os indivíduos a mudarem o posicionamento frente à nova realidade. Lipovesky et al. (2005) caracterizam que esta nova era apresenta a ideia de que a sociedade precisa saber um volume considerável de informações. Quanto mais o indivíduo conhece sobre todos os assuntos, mais ele é respeitado, porém considerar essa hipótese verdadeira é um equívoco porque muitas vezes o saber sobre determinado assunto não é o mesmo que o saber aprofundado; são conhecimentos superficiais que levam a nova sociedade a um status de conhecimento.

Com a busca recorrente de novos conhecimentos e informações que geram nos indivíduos a sensação de saber cada vez mais, Giddens (2002) destaca a modernidade como ferramenta que não atua com o intuito de gerar certezas 
sobre algo, mas sim, em uma circunstância de dúvidas recorrentes. A geração que se conforma com tudo que está sendo imposto pelas novas configurações de sociedade e de indivíduo.

Na perspectiva de Dantas, "somos intimados a participar de um mundo em movimento acelerado, imediatista, efêmero, que promove o narcisismo exacerbado e um modo de relação objetivo e específico entre os homens" (DANTAS, 2011, p. 42).

Além da própria modernização, outra modificação significante é a das relações sociais, que começam a ser alteradas a partir do novo contexto de sujeito individualizado formando uma sociedade. Giddens (1991) apresenta que a mídia eletrônica é o meio principal para que a preocupação com deslocamento surgisse; a necessidade da presença, que é distante. Juntamente com tal análise, Ferraz Júnior et al. (2005) propõem que o mundo físico/real é modificado em muitas circunstâncias pelo mundo virtual, fazendo que futuramente não haja a percepção da diferença do físico/real para o virtual.

\begin{abstract}
A falta de sentido pessoal - a sensação de que a vida não tem nada a oferecer - torna-se um problema psíquico fundamental na modernidade tardia. Devemos entender esse fenômeno em termos de uma repressão de questões morais que a vida cotidiana coloca, mas às quais nega respostas. "Isolamento existencial" não é tanto uma separação do indivíduo dos outros, mas uma separação dos recursos morais necessários para viver uma existência plena e satisfatória. $\mathrm{O}$ projeto reflexivo do eu gera programas de realização e controle (GIDDENS, 2002, p. 16).
\end{abstract}

Envelhecimento na pós-modernidade: o que a psicologia tem a ver com isso?

Após contextualizarmos as duas temáticas, tanto o envelhecimento quanto a pós-modernidade, apresentando aspectos e características que foram consideradas relevantes ao abordarmos o tema proposto, empreenderemos um esforço de compreensão a partir do diálogo entre as partes acima referidas para olharmos de maneira mais congruente e, se possível, com o menor número de estereótipos, o ato de envelhecer; além de analisar se esse processo ainda é o 
mesmo ou não diante das constantes e velozes mudanças próprias do período pós-moderno.

Atualmente, observamos que o processo de envelhecer vem sendo acompanhado de significativas transformações na maneira de perceber a vida, além de uma elaboração da existência dentro do contexto e exigências próprias do envelhecimento. Tais mudanças atingem tanto a pessoa enquanto elaboração subjetiva de uma vida que envelhece e as demais relações constituintes e vigentes quanto o próprio meio social o qual possui uma forte influência. Ou seja, uma espécie de poder ativo sobre o idoso que agora deixa de ser uma pessoa fadada a inatividade, transformando-se, segundo a lógica do mercado, em consumidor de uma gama de produtos e serviços que oferecem desde uma vida mais saudável até as promessas de uma fonte eterna de juventude para retardar ao máximo a implacável e inalienável ação da temporalidade, mas sempre sob a óptica do consumir para ter uma velhice melhor.

Stuart-Hamilton (2002) aponta que mesmo diante os inúmeros fatores que circundam a pessoa velha, como quais atitudes ela toma, qual aparência ela possui e quanto tempo ela apresenta-se ociosa, no futuro virá uma modificação na visão desses fatores, sendo focalizado mais a aparência, o que faz um novo mercado surgir, a exemplo das cirurgias plásticas e reposição de hormônios que já começam a transformar os aspectos físicos que revelam o envelhecimento.

\footnotetext{
A publicidade, os manuais de autoajuda e as receitas dos especialistas em saúde estão empenhados em mostrar que as imperfeições do corpo não são naturais nem imutáveis e que, com esforço e trabalho corporal disciplinado, pode-se conquistar a aparência desejada; as rugas ou a flacidez se transformam em indícios de lassitude moral e devem ser tratadas com a ajuda dos cosméticos, da ginástica, das vitaminas, da indústria de lazer (DEBERT, 1999, p. 20-21).
}

Não podemos negar que estamos diante de um paradigma estético, e não mais ético, regendo a vida humana, mas apropriadamente podemos considerar que vivemos um deslocamento do campo de sentido da vida, ou seja; a prioridade passou a ser a primazia do belo sobre a necessidade do ético, do verdadeiro, do que eleva o espírito humano e dá sentido às nossas ações. 
As maiores preocupações na atualidade, portanto, apontam para uma necessidade de padronização dos corpos que passam a ser objeto de manipulação constante. Diante dos tantos procedimentos de inúmeros profissionais “especialistas em beleza" os quais ofertam verdadeiras panaceias, não poderia parecer minimamente estranho a posição de alguém a respeito do "envelhecimento natural" em que as marcas do tempo não são atenuadas nem retiradas, mas recebem toda a devida reverência, como uma consequência sagrada do envelhecer.

Debert (1999) considera que mesmo que a sociedade tenha se voltado para um envelhecer positivo, levando as pessoas a práticas que vão estimular o cuidado com o corpo e a modificação na imagem que o sujeito reelabora sobre si, isso não irá ocultar as complicações que acometem o envelhecimento.

\footnotetext{
Alternativamente, as tentativas de retardar o envelhecimento podem ter tanto sucesso que ninguém será capaz de dizer quão velho é um adulto. Isso levanta uma série de possíveis dilemas. Algumas pessoas talvez queiram envelhecer "naturalmente" - e será que por isso se transformarão em excluídos? E se os tratamentos antienvelhecimento forem muito caros e só determinadas classes sociais tiverem acesso a eles? Talvez surja uma nova neurose, afligindo pessoas que se sentem "aprisionadas" em um corpo que tem a idade errada para suas ideias e atitudes (STUART-HAMILTON, 2002, p. 188).
}

Partindo disso, o sujeito na sua constituição como ser idoso passa por um processo de elaboração subjetiva que é influenciada socialmente. Debert (1999) destaca que o indivíduo velho passa a se ausentar da visão do envelhecimento que havia antigamente, arcaica para os modos de vida de hoje, logo o sujeito volta-se para um novo processo de redirecionamento do novo espaço de ser na sociedade, gerando assim comportamentos, atitudes, emoções e construções de si baseadas no que é imposto para eles pelo que é ditado na nova era em que vivemos.

E mais uma vez o olhar do outro (social) tornou-se um aspecto mais relevante na constituição dessa fase de vida, ganhando destaque. O idoso começa a se ausentar de uma análise própria e começa a se preocupar mais com o que o social apresenta sobre ele. Hoje, mais do que antigamente, o olhar biológico, que 
está voltado para as marcas que o idoso traz, torna-se cada vez mais uma preocupação, pois, a partir desses elementos, o velho entra no estágio de enquadramento social, fazendo esquecer de que existe um estágio de desenvolvimento humano, que não apenas se volta para questões físicas, mas também é constituído de outros aspectos, e assim como em outras fases, é acometido de características próprias que a sociedade infelizmente quer esconder para uma ilusória fuga de quem se é realmente.

Percebemos mudanças no recorrer dos anos em relação à temática proposta, com a presença de uma alteração de papéis na sociedade, na qual o próprio idoso não sabe exatamente onde esse personagem está inserido e como ele realmente merece ser visto. A Psicologia ocupa-se, poderíamos dizer inicialmente, dos processos subjetivos que são produtos da elaboração das reações daquilo que é vivido pela pessoa, seja consigo, com o meio ou com os outros, como também do que não pode ser oportunamente realizado e vivenciado, uma vez que observamos dois discursos presentes ao redor do envelhecimento, ora trazendo memórias do que fora vivido, ora remetendo às lamentações do não realizado, com uma frustração saudosista.

Faz-se necessário considerar que a pós-modernidade já é algo em desenrolar - não só um momento pontual definido na história da humanidade ocorre também mudanças com o idoso no processo de desenvolvimento humano, não podendo ser visto apenas como algo demarcado por uma idade, mas sim como uma continuidade.

Compreendendo a Psicologia do Envelhecimento, os psicólogos têm papel fundamental na promoção de uma escuta à pessoa idosa, além de auxílio na elaboração da própria identidade, atuação e tomada de posse do papel social nesses tantos e não menos velozes deslocamentos, os quais todos nós estamos submetidos. É importante trabalhar o enfrentamento das dificuldades presentes no sujeito que envelhece para que, a partir da escuta, possa existir uma abertura no processo de compreensão, dando suporte no processo de significação, se assim for desejado, bem como visando apresentar suas potencialidades dentro desse contexto. 
Outrora, era mais plausível a compreensão do idoso como fonte de sabedoria pelo acúmulo dos anos vividos ou até mesmo referência de valores e virtudes específicos quase que inatingíveis por outras faixas etárias. Sabemos que não acontece dessa maneira, pelo contrário o desfocamento da identidade do idoso gera uma radical desorientação do que se é e do lugar de presença e atuação efetiva da pessoa nesse processo. Um dos focos abordados pela Psicologia é a compreensão de quem é esse indivíduo dentro do próprio processo de desenvolvimento, analisando se ele enxerga a si como personagem ativo, abrindo espaço para que o idoso possa se ver como um ser presente e cheio de potências para estar, viver e compreender o próprio estado.

O envelhecer é um momento singular por excelência, porém não necessariamente isolado. Faz-se pertinente trazer o papel da Psicologia que se volta para o social deste sujeito e busca resgatar a possibilidade de realizar algo tanto a partir de si como em conjunto a outras pessoas, dando a possibilidade de analisar como estão as relações sociais do idoso. Ao adentrar a essa área do conhecimento, podemos promover atividades que estimulem a interatividade, tais como os grupos de conversa e de partilhas mais informais, grupos de jogos de tabuleiro, dança de salão, canto coral, teatro e artesanato, grupos de estudo e de debates e demais lugares em que a pessoa possa descobrir o protagonismo gerativo.

Sob um ponto de vista a princípio pouco comum, o envelhecimento também requer certa especificidade diante do saber psicológico no que toca as psicoterapias mesmo nem sempre os idosos sendo os alvos dessas práticas. Se o adoecimento da pessoa requer um tratamento a partir das determinadas abordagens psicoterapêuticas, ainda mais na fase avançada da vida, essa particularidade torna-se necessária e realçada.

Diante do exposto, tecemos uma crítica a própria profissão, que infelizmente está voltando-se apenas agora para o tema proposto devido ao aumento crescente da população idosa. Percebemos a Psicologia como uma área que deveria ser ativa nesse contexto por auxiliar, por meio dos profissionais, a visão sobre os estágios de desenvolvimento humano. $\mathrm{O}$ aprofundamento em 
estudos e análises da temática produz alteração na concepção do segmento, abrindo espaço para um trabalho multiprofissional e apresentando as mais diversas intervenções pertinentes.

\section{Considerações Finais}

Constatamos que o indivíduo geralmente não sabe lidar com os "polos referenciais" da existência e aqui nos referimos tanto a infância quanto a velhice. Tendo como referência o envelhecer, o olhar que o sujeito possui de si mesmo e do seu lugar com as necessárias adaptações torna-se decisivo para a vivência de uma "nova velhice".

Vivemos inegavelmente em um momento privilegiado e, ao mesmo tempo, desafiador da história, uma vez que essa fase está estritamente ligada à ação humana e experimenta um movimento de irreversibilidade, ou seja; o tempo não para nunca. A percepção da pessoa que envelhece num contexto de hipermodernidade se confronta entre a melancolia saudosista do que foi vivido e a provocação contínua e urgente de uma adaptação aos vários estímulos presentes.

Diante do horizonte desafiador da pós-modernidade, o envelhecimento, enquanto processualidade da existência, está submetido à pertinência do tema e se justifica como também a necessária atitude de contínua construção a partir da elaboração do sujeito que envelhece diante das situações vividas. Tal condição nos permite considerar que este trabalho é apenas uma "porta de entrada" para um caminho a ser desbravado. 
Salientamos que o assunto é relevante e precisa de um olhar mais crítico, profundo e maduro sobre as possibilidades de prevenção e intervenção que sejam mais viáveis para criar um caminho de maior consciência diante da experiência vivida no envelhecer. Podendo ampliar estudos dentro da área da saúde utilizando-se de uma equipe multiprofissional, onde haveria o olhar de cada área específica, tornando a pesquisa mais completa, realizando assim uma análise mais aprofundada e com novas possibilidades de visão sobre a temática proposta. 


\section{REFERÊNCIAS}

BEAUVOIR, Simone de. A velhice. Rio de Janeiro: Nova Fronteira, 1990.

DANTAS, Jurema Barros. Angústia e existência na contemporaneidade. Rio de Janeiro: Rubio, 2011.

DEBERT, Guita Grin. Socialização e processos de reprivatização do envelhecimento. São Paulo: Editora da Universidade de São Paulo: Fapesp, 1999.

DOMINGUES, Adriana Rodrigues. O envelhecimento, a experiência narrativa e a história oral: um encontro e algumas experiências. Revista Psicologia

Política, São Paulo, v. 14, n. 31, p. 551-568, dez. 2014. Disponível em http:// pepsic.bvsalud.org/scielo.php?script=sci_arttext\&pid=S1519_549X2014000300009\&lng=pt\&nrm=iso. Acesso em: 2 mar. 2018.

FERRAZ JUNIOR, Tercio Sampaio et al. Possibilidades virtuais da realidade: ontem e hoje. In: FORBES, Jorge; REALE JÚNIOR, Miguel; FERRAZ JÚNIOR, Tercio Sampaio (org.). A invenção do futuro. Barueri: Manole, 2005.

GIDDENS, Anthony. As consequências da modernidade. São Paulo: Editora da Universidade Estadual Paulista, 1991.

GIDDENS, Anthony. Modernidade e identidade. Rio de Janeiro: Jorge Zahar, 2002.

GIL. Antônio Carlos. Como elaborar projetos de pesquisa. 5. ed. São Paulo: Atlas, 2010.

GUERRA, Ana Carolina; CALDAS, Célia Pereira. Dificuldades e recompensas no processo de envelhecimento: a percepção do sujeito idoso. Ciência \& Saúde Coletiva, Rio de Janeiro, v. 15, n. 6, p. 2931-2940, set. 2010. Disponível em http:/ / www.scielo.br/scielo.php?script=sci_arttext\&pid=S141381232010000600031\&lng=en\&nrm=iso. Acesso em: 2 mar. 2018.

LIPOVETSKY, Gilles. A era do vazio: ensaios sobre o individualismo contemporâneo. Barueri: Manole, 2005.

LIPOVETSKY, Gilles et al. Apresentação de Gilles Lipovetsky e introdução aos debates. In: FORBES, Jorge; REALE JÚNIOR, Miguel; FERRAZ JÚNIOR, Tercio Sampaio (org.). A invenção do futuro. Barueri: Manole, 2005. 
LIPOVETSKY, Gilles. Os tempos hipermodernos. Tradução Mário Vilela. São Paulo: Barcarolla, 2007.

PAPALIA, Diane E.; OLDS, Sally Wendkos. Desenvolvimento humano. Porto Alegre: Artes Médicas, 2000.

ROSA, Carlos Mendes; VILHENA, Junia de. O silenciamento da velhice: apagamento social e processos de subjetivação. Revista Subjetividades, Fortaleza, v. 16, n. 2, p. 9-19, ago. 2016. Disponível em http:// pepsic.bvsalud.org/scielo.php?script=sci_arttext\&pid=S2359_ 07692016000200001\&lng=pt\&nrm=iso. Acesso em: 26 set. 2017.

STUART-HAMILTON, Ian. A psicologia do envelhecimento: uma introdução. Porto Alegre: Artmed, 2002. 


\section{6}

Conhecimento dos

manipuladores sobre boas

práticas de manipulação em

uma unidade de

alimentação no município

de Maracanaú 


\title{
6 CONHECIMENTO DOS MANIPULADORES SOBRE BOAS PRÁTICAS DE MANIPULAÇÃO EM UMA UNIDADE DE ALIMENTAÇÃO NO MUNICIPIO DE MARACANAÚ
}

\author{
Nágilla Karine Braga \\ Larissa Pereira Aguiar \\ Daniele Vasconcelos Fernandes Vieira
}

\section{Resumo}

Introdução: A alimentação é caracterizada como uma forma voluntária e consciente pelo qual o indivíduo adquire gêneros para seu consumo. Uma Unidade de Alimentação e Nutrição (UAN) deve ser entendida não só como um local onde ocorre a manipulação, preparação, armazenamento de refeições, mas, sim como um sistema de operacionalização onde irá ter processos padronizados para que não ocorra a variação do produto de manipulador para manipulador. A contaminação alimentar pode ocorrer durante a manipulação do alimento ou no ambiente em que ocorrer a produção e esses estabelecimentos devem estar dentro das legislações vigentes visando segurança alimentar dos seus consumidores, contribuindo para o alcance dessa qualidade. Objetivo: Avaliar o nível de conhecimento dos manipuladores sobre boas práticas de manipulação em uma unidade de alimentação no município de Maracanaú. Métodos: O local de execução para esse estudo foi no Restaurante Popular localizado na cidade de Maracanaú-CE, onde teve uma amostra de 12 participantes. Os dados foram coletados a partir de um questionário de verificação adaptado de Souza (2005), composto por aspectos socioeconômicos e conhecimentos sobre as boas práticas. Resultados: Os dados foram analisados a partir de tabelas e como resultado todos os participantes $(100 \%)$ foram classificados como excelentes, totalmente adequado ao cargo; mesmo a metade deles não possuindo alguma capacitação sobre boas práticas de manipulação. Considerações finais: As boas práticas de manipulação, são necessárias dentro de qualquer unidade de alimentação e nutrição, pois garantem que o alimento que está sendo ofertado seguro.

Palavras-chaves: Alimentação. Unidade de Alimentação e Nutrição. Manipulação. Manipulador. 


\section{Introdução}

A alimentação é caracterizada como uma forma voluntária e consciente pelo qual o indivíduo adquire gêneros para seu consumo. A Organização Mundial da Saúde em 1974, delimitou que a alimentação possui uma importância no crescimento físico, na capacidade de aprendizado e na produtividade no trabalho (SILVA JUNIOR, 2008).

Uma Unidade de Alimentação e Nutrição (UAN) deve ser entendida não só como um local onde ocorre a manipulação, preparação, armazenamento de refeições, mas, sim como um sistema de operacionalização onde irá ter processos padronizados para que não ocorra a variação do produto de manipulador para manipulador. Apresentando assim como o objetivo geral da UAN, fornecer um alimento seguro e dentro dos padrões estabelecidos, contribuindo assim para uma qualidade de vida para seus consumidores (FONSECA; SANTANA, 2012).

A saúde é um elemento participante da procura pela qualidade de vida e dentro dela há fatores que podem ajudar na obtenção dessa condição, um deles é a alimentação, onde tem um papel fundamental, mas, pode causar prejuízos também se não seguir as orientações corretas. Diante disso, as Unidades de Alimentação e Nutrição (UAN) devem estar dentro das legislações vigentes para esse tipo de estabelecimento, visando segurança alimentar dos seus consumidores, contribuindo para o alcance dessa qualidade (SOARES, 2015).

Visando essa segurança alimentar e a padronização da produção, a presença do nutricionista nesse processo é de suma importância, tendo como seu principal papel promover um bem-estar através da oferta de alimento seguro para os indivíduos, evitando assim as doenças transmitidas por alimentos (DTA) (FONSECA; SANTANA, 2011).

Segundo Rigodanzo et al. (2016), a contaminação através de agentes bacterianos faz parte das condições prováveis para a ocorrência de DTA. O autor 
ainda cita que no Brasil o Staphylococcus aureus é um dos principais determinantes dessas doenças.

A contaminação alimentar pode ocorrer durante a manipulação do alimento ou no ambiente em que ocorrer a produção (MEDEIROS; CARVALHO; FRANCO, 2017).

Segundo Brasil (2016), as DTA são patologias onde alguns dos seus sintomas são: vômitos, diarreias, náuseas, etc. acompanhadas de manifestações no sistema nervoso central, no rim, etc.

Conforme dados epidemiológicos, no Brasil de 2007 a 2016, ocorreu cerca de 6.632 surtos com 109 óbitos em pessoas de faixa etária de 20 a 49 anos e um número maior no sexo masculino (BRASIL, 2016).

Outro dado, constatou que dentro desse mesmo período, a região sudeste, a mais populosa, teve cerca de 43,8\% de casos, ficando assim em primeiro no patamar de regiões. Logo após ele, vem a região sul com 24,8\% (BRASIL, 2016).

Dentre as medidas necessárias para produzir um alimento seguro, estar a capacitação dos manipuladores que através de erros na sua higiene pessoal ou o não cumprimento das práticas obrigatórias, podem levar a uma contaminação (DEVIDES; MAFFEI; CATANOZI, 2014).

\section{Objetivo}

Avaliar o nível de conhecimento dos manipuladores sobre boas práticas de manipulação em uma unidade de alimentação no município de Maracanaú 


\section{Método}

Trata-se de um estudo descritivo de natureza quantitativa. O local da pesquisa foi o Restaurante Popular, localizado no município de Maracanaú. O Restaurante Popular é uma estratégia da Secretaria de Assistência Social e Cidadania com o objetivo de promover a alimentação saudável, com fácil acesso e de baixo custo. Cada refeição custa $R$ \$1,00 (o prato pronto) e seu público-alvo são os moradores do Município de Maracanaú cadastrados em Cadastro Único do Governo Federal, Programa de Bolsa Família e beneficiários dos projetos da Secretaria de Assistência Social e Cidadania. Funciona também como restaurante escola, onde são oferecidos cursos nas áreas de gastronomia e nutrição, além de palestras, oficinas e campanhas educativas com a finalidade de desenvolver ações de educação alimentar, promoção da saúde e combate ao desperdício (PREFEITURA MUNICIPAL DE MARACANAÚ, 2018).

O restaurante tem a capacidade de oferecer 600 refeições/dia e seu cardápio segue a norma estabelecida no Programa de Alimentação ao Trabalhador (PAT) do Governo Federal, onde cada prato contém 1.200 Kcal compostos por arroz, feijão, carne, guarnição, salada, sobremesa e suco de fruta variando conforme o dia da semana. O seu horário de funcionamento é de segunda a sexta-feira, das $10 \mathrm{~h} 45$ às $13 \mathrm{~h}$. Diariamente, os 15 primeiros minutos de funcionamento (das $10 \mathrm{~h} 45$ às $11 \mathrm{~h}$ ) é destinado ao acesso preferencial de idosos e pessoas com deficiência (PREFEITURA MUNICIPAL DE MARACANAÚ, 2018).

A amostra foi composta por manipuladores de ambos os sexos com no mínimo 6 meses de experiência. O estudo aconteceu no período de agosto a outubro. Participaram aqueles que estavam conforme os pré-requisitos apresentados e os que assinaram de modo espontâneo e voluntário o Termo de Consentimento Livre Esclarecido (Apêndice A) que é regulamentado segundo a Resolução CNS n ${ }^{\circ}$ 466/12 (BRASIL, 2013). A amostragem utilizada foi com uma 
quantidade de 12 participantes por ser a quantidade total de manipuladores do local.

Foram incluídos no estudo manipuladores de todo o processo de produção desde o almoxarifado até a cozinha de ambos os gêneros; com no mínimo 6 meses de experiência e deviam ter o conhecimento básico de leitura e escrita.

Foram excluídos manipuladores que não tenham conhecimento básico de leitura e escrita; que possuíam menos 6 meses de experiência; que apresentassem distúrbios neurológicos e os participantes desistentes do estudo.

A coleta de dados deu-se a partir da aplicação de um questionário adaptado de Genta; Maurício e Matioli (2005) que abordaram aspectos socioeconômicos, conhecimentos sobre as boas práticas. Antes de iniciar a pesquisa foi explicado os objetivos do trabalho e a sua importância para o manipulador e para o local.

A análise que foi feita avaliou o conhecimento dos manipuladores sobre boas práticas de manipulação. Os resultados foram analisados a partir de tabelas adaptado de Genta; Maurício e Matioli (2005) a partir de que cada questão correta equivale a $5 \%$ e foram classificadas a partir dos seguintes critérios segundo Genta; Maurício e Matioli (2005):

Excelente: Com um total de $80 \%$ a $100 \%$ de respostas corretas

Regular: Com um total de 50\% de respostas corretas

Ruim: Com um total de 30\% de respostas corretas

Péssimo: Com um total menor que 30\% de respostas corretas 
Os manipuladores foram informados sobre os objetivos da pesquisa e caso eles aceitassem participar do estudo assinavam o Termo de Consentimento Livre Esclarecido (Apêndice A) que é regulamentado segundo a Resolução CNS $\mathrm{n}^{\mathrm{o}} 466 / 12$, podendo também desistir quando quiserem (BRASIL, 2013). Essa análise foi submetida e aprovada pelo Comitê de Ética em Pesquisa da Academia Cearense de Odontologia (ACO)/Centro de Educação com o número do Parecer 2.893.962 e só foi reproduzido após a aprovação. Nessa pesquisa foi colocado em primeiro aspecto ético, a confidencialidade das informações, a fins de pesquisa científica em que os dados para os resultados foram utilizados em anonimato.

\section{Resultados e Discussão}

A amostra encontrada para a coleta foi de 12 participantes por ser a quantidade total encontrada no local, sendo utilizado somente 10 participantes pelo fato de que 2 deles não estavam de acordo com os critérios de inclusão do estudo, diante disso foram incluídos os participantes de todo o processo de produção desde o almoxarifado até os manipuladores da cozinha.

Tabela 1 - Perfil sócio econômico dos manipuladores de alimentos do Restaurante Popular de Maracanaú - CE

\begin{tabular}{|c|c|c|c|c|}
\hline Sexo & $\begin{array}{c}\text { Média } \\
\text { da idade }\end{array}$ & Nível de escolaridade & $\begin{array}{c}\text { Estuda } \\
\text { atualmente }\end{array}$ & $\begin{array}{c}\text { Tempo de } \\
\text { Recrutamento }\end{array}$ \\
\hline $\begin{array}{c}\text { Masculino } \\
(60 \%)\end{array}$ & 42 anos & $\begin{array}{c}\text { Ensino Médio } \\
\text { Completo }\end{array}$ & Não estudam & 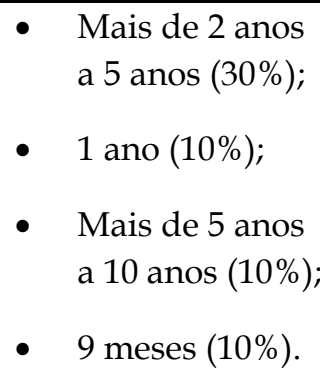 \\
\hline $\begin{array}{c}\text { Feminino } \\
(40 \%)\end{array}$ & 43 anos & $\begin{array}{c}\text { Ensino Médio } \\
\text { Completo }\end{array}$ & Não estudam & $\begin{array}{ll}\text { - } & \text { Mais de } 5 \text { anos } \\
& \text { a } 10 \text { anos }(20 \%) ; \\
\text { - } & 1 \text { ano }(10 \%) ; \\
\text { - } & \text { Mais de } 1 \text { ano a } \\
& 2 \text { anos }(10 \%) .\end{array}$ \\
\hline
\end{tabular}

Fonte: Dados da pesquisa (2018). 
Boaventura et al. (2017) realizaram uma pesquisa com 17 manipuladores de 3 UAN de uma comunidade, sendo duas creches e um centro de produção de lanches para comercialização que funciona sem fins lucrativos situadas na zona sul de São Paulo/SP. Nela foi encontrado que a maioria dos manipuladores eram do sexo feminino (76\%). Quanto ao nível de escolaridade 47\% possuíam o ensino médio completo.

A capacitação voltada para as boas práticas de manipulação é de grande importância, pois é um incentivo ou até uma novidade para os manipuladores produzirem um alimento seguro que é o objetivo principal. Nessa pesquisa como mostra o Gráfico 1, metade dos entrevistados (50\%) possuíam o curso ou treinamento de boas práticas manipulação e a outra metade (50\%) não possuíam nenhum curso ou treinamento em comparação com Ribeiro et al. (2010) que realizaram uma pesquisa nas empresas do setor alimentício de Ivaiporã/PR a fim de identificar as possíveis irregularidades existentes e capacitar os manipuladores de alimentos, onde obteve - se que a maioria dos manipuladores $(83 \%)$ já tinham algum tipo de treinamento voltado para as boas práticas de manipulação e somente $17 \%$ não possuíam capacitação.

Gráfico 1 - Manipuladores que possuem e que não possuem curso de boas práticas

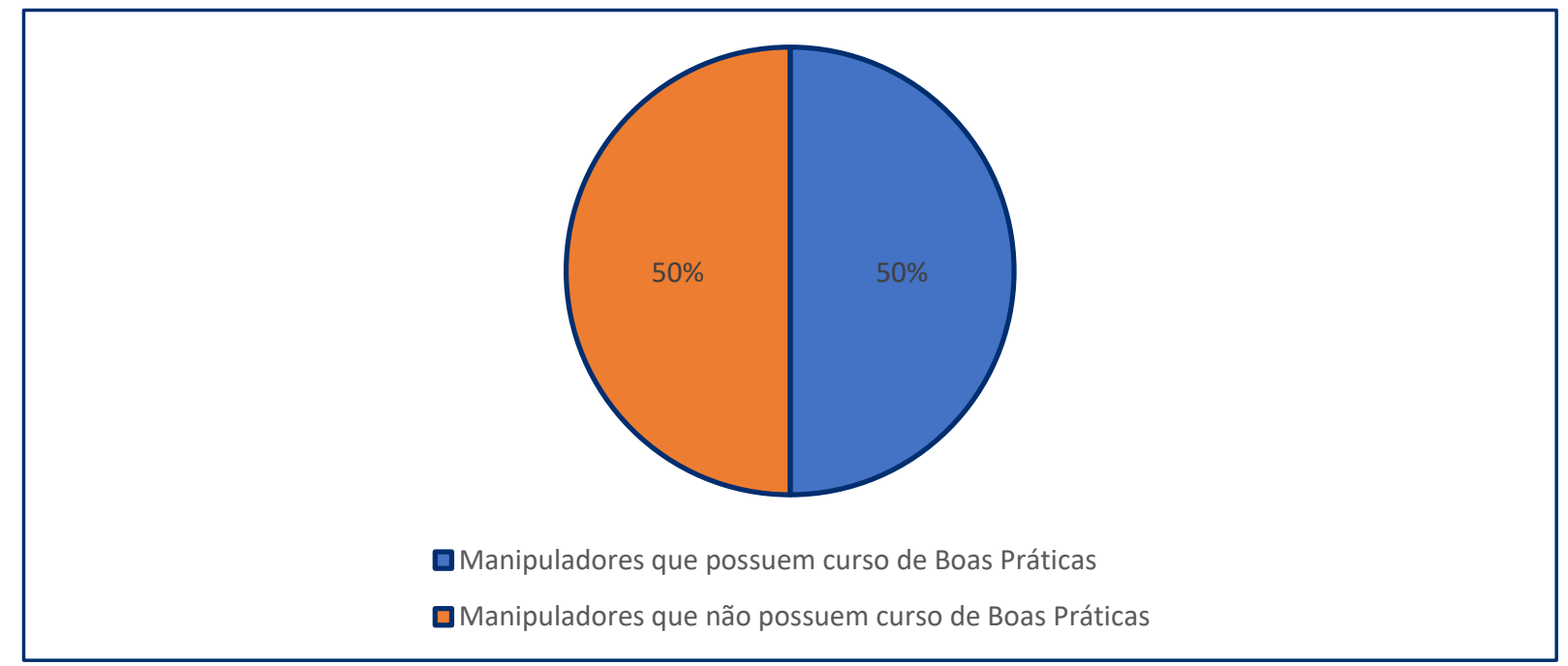

Fonte: Dados da pesquisa (2018). 
Embora a capacitação apresente uma relevância na produção, acredita-se que a vivência ensine as práticas corretas e assim gerando um alimento seguro.

No que se refere à avaliação do nível de conhecimento dos manipuladores sobre as boas práticas de manipulação, foi encontrado que todos (100\%) estão classificados como excelentes, totalmente adequado ao cargo; mesmo uma metade deles não possuindo alguma capacitação de boas práticas de manipulação.

Mello et al. (2010) avaliaram o nível de conhecimento dos manipuladores sobre as boas práticas de manipulação dos restaurantes públicos populares do estado do Rio de Janeiro-RJ com uma quantidade de 103 manipuladores de alimentos. Teve como resultado um conhecimento dos manipuladores regular com uma média de 56,09\% sendo que os Restaurantes Públicos Populares 3 e 10 obtiveram nível de conhecimento deficiente, respectivamente, 48,3 e 49,1\% de respostas corretas e em nenhum dos RPP foi constatado bom nível de conhecimento sobre boas práticas de manipulação.

Góios et al. (2017) efetuaram uma análise em 28 unidades de alimentação de diferentes setores de alimentação coletiva na cidade do Porto, Portugal onde em cada unidade selecionou 3 manipuladores aleatoriamente com o objetivo de avaliar os conhecimentos dos manipuladores de alimentos sobre segurança e alergia alimentar, em restaurantes e unidades de alimentação. Teve um total de 81 manipuladores sendo a maioria do sexo feminino com uma idade média de 38 anos variando entre os 20 e os 57 anos de idade. O nível de escolaridade foi de $55 \%$ possuía o ensino básico completo e $6 \%$ somente tinham nível superior. Em relação a experiência 16\% trabalhavam há menos de 2 anos e $38 \%$ entre 2 a 8 anos. Quanto à formação profissional voltada para a segurança alimentar, 87\% dos participantes tinham alguma formação e 49\% dessas capacitações foram ofertadas no local.

Machado; Pascoal e Dias (2018) realizaram um estudo em restaurantes e lanchonetes de uma instituição de ensino em Salvador-BA com uma amostra de 25 manipuladores e teve como objetivo geral diagnosticar a capacitação 
profissional e de boas práticas de manipuladores de alimentos desses restaurantes e lanchonetes. Foi encontrado que ocorreu um predomínio do sexo feminino e quanto a exames de custo elevado como o de coprocultura são menos realizados. Os autores constataram também que mais da metade desses manipuladores na empresa não possuía uma capacitação; alegou também que $56 \%$ dos participantes afirmaram que a empresa possui manual de boas práticas e quanto ao conhecimento desse material a maioria relatou conhecer o manual de boas práticas.

Em um certo estudo feito por Behrens et al. (2015), para que um alimento seja considerado seguro, os consumidores conceituam aquele manipulado de forma adequada, fresco e livre de pesticidas. Por isso que é importante o manipulador ter essa dominância do assunto advinda de treinamentos, cursos oferecidos pelo seu local de trabalho, embora a vivência ensine como foi citado antes.

Na pesquisa feita por Valiati et al. (2016) onde foram visitados 49 restaurantes, mas, somente em 29 destes os responsáveis aceitaram fazer o estudo obteve como resultado que 7 dos 49 locais visitados não havia funcionários treinados e quanto ao desempenho dos participantes 13 foram classificados como excelente, 14 como bom e dois como regular.

No estudo feito por Ferreira et al. (2013), em dez hospitais públicos de Salvador-BA encontrou que a maioria dos manipuladores foram treinados (92,8\%), porém o nível de conhecimento foi insuficiente $(65,8 \%)$ da amostra. Essa pesquisa teve como objetivo avaliar o nível de conhecimento, atitudes e práticas em segurança alimentar dos manipuladores de alimentos em hospitais públicos de Salvador, Bahia. 


\section{Considerações Finais}

As Boas Práticas de Manipulação se fazem necessárias dentro de todos os estabelecimentos onde são produzidos e ofertados alimentos, pois é a garantia da oferta de um alimento seguro que é aquele livre de contaminação físicas e químicas, evitando assim as doenças transmitidas por alimentos.

As capacitações sobre as boas práticas devem ser oferecidas pelo estabelecimento ministrados por profissionais adequados e ocorrendo anualmente. É recomendado que ocorra reuniões semanalmente ou no fim de cada dia de produção para que seja discutido os problemas que ocorreram na semana ou no dia todo, mantendo uma boa relação que acarreta diretamente a produtividade e a satisfação de poder trabalhar nesse estabelecimento.

A presença das Boas Práticas de Manipulação no dia a dia e a atuação de uma boa equipe leva a uma alta produção e a certificação que o alimento que está sendo produzido está seguro para o consumidor.

Nessa pesquisa teve tópicos voltados para as Boas Práticas dando ênfase na segurança, expondo sua importância; para o manipulador onde foi relatado sobre a sua higiene e sobre a saúde dele. Apresentou uma significante relevância, pois mostrou o valor das Boas Práticas de Manipulação na produção e apresentou como benefício a importância do conhecimento das ações de boas práticas de manipulação nos manipuladores para a obtenção de um alimento seguro, afinal eles são os principais veículos para a contaminação do alimento e, posteriormente, o desenvolvimento e a ocorrência de uma doença transmitida por alimento (DTA) nos seus usuários. Além dos manipuladores ganharem um certo reconhecimento sendo benéfico para o seu trabalho e para a Unidade de Alimentação e Nutrição (UAN). 


\section{Referências}

BEHRENS, Jorge H. et al. Social representation of safety in food services. Food Research International, v. 74, p. 324-328, Aug. 2015.

BOAVENTURA, Luara Thabata Alves et al. Conhecimento de manipuladores de alimentos sobre higiene pessoal e boas práticas na produção de alimentos. Revista Univap, v. 23, n. 43, p. 53-62, set. 2017.

BRASIL. Ministério da Saúde. Secretaria de Vigilância em Saúde. Surtos de doenças transmitidas por alimentos no Brasil. [Brasília, DF]: Ministério da Saúde, 2016. Disponível em:

http://portalarquivos.saude.gov.br/images/pdf/2016/junho/08/Apresenta---o-Surtos-DTA-2016.pdf. Acesso em: 12 mar. 2018.

DEVIDES, Gabriela Gianini Guilherme; MAFFEI, Daniele Fernanda; CATANOZI, Maria da Penha Longo Mortatti. Perfil socioeconômico e profissional de manipuladores de alimentos e o impacto positivo de um curso de capacitação em boas práticas de fabricação. Brazilian Journal of Food Technology, Campinas, v. 17, n. 2, p. 166-176, abr./jun. 2014.

FERREIRA, Jeane dos Santos et al. Conhecimento, atitudes e práticas em segurança alimentar de manipuladores de alimentos em hospitais públicos de Salvador, Bahia. Revista Baiana de Saúde Pública, n. 37, p. 35-55, 2013.

Disponível em: http://files.bvs.br/upload/S/01000233/2013/v37nSupl_1/a3424.pdf. Acesso em: 24 set. 2021.

FONSECA, Karina Zanoti; SANTANA, Gizane Ribeiro de. Guia prático para gerenciamento de unidades de alimentação e nutrição. Cruz das Almas: UFRB, 2012.

FONSECA, Karina Zanoti; SANTANA, Gizane Ribeiro de. O nutricionista como promotor da saúde em unidades de alimentação e nutrição: dificuldades e desafios do fazer. Enciclopédia Biosfera, Goiânia, v. 7, n. 13, p. 1466-1476, nov. 2011.

GENTA, Tânia Maria de Souza; MAURÍCIO, Angélica Aparecida; MATIOLI, Graciette. Avaliação das boas práticas através de check-list aplicado em restaurantes self-service da região central de Maringá, Estado do Paraná. Acta Scientiarum Health Sciences, v. 27, n. 2, p. 151-156, 2005. Disponível em: https://www.redalyc.org/pdf/3072/307223952008.pdf. Acesso em: 24 set. 2021. 
GÓIOS, Ana et al. Conhecimentos de manipuladores de alimentos sobre segurança dos alimentos e alergias. Higiene Alimentar, Portugal, v. 31, n. 264/265, p. 38-44, jan./fev. 2017.

MACHADO, Ana Paula de Jesus; PASCOAL, Tatiane da Silva; DIAS, Rose M. Feliciano. Capacitação profissional e em boas práticas de manipuladores de restaurantes e lanchonetes localizados em IES de Salvador, BA. Higiene Alimentar, Salvador, v. 32, n. 276/277, p. 43-47, jan./fev. 2018.

MEDEIROS, Maria das Graças Gomes de Azevedo; CARVALHO, Lúcia Rosa de; FRANCO, Robson Maia. Percepção sobre a higiene dos manipuladores de alimentos e perfil microbiológico em restaurante universitário. Ciência \& Saúde Coletiva, v. 22, n. 2, p. 383-392, 2017. Disponível em: https://doi.org/10.1590/1413-81232017222.17282015. Acesso em: 24 set. 2021.

MELLO, Aline Gomes de et al. Conhecimento dos manipuladores de alimentos sobre boas práticas nos restaurantes públicos populares do estado do Rio de Janeiro. Brazilian Journal of Food Technology, Campinas, v. 13, n. 1, p. 60-68, jan. /mar. 2010.

PREFEITURA MUNICIPAL DE MARACANAÚ. Restaurante popular de Maracanaú comemora 10 anos de atividades. Marcanaú: Prefeitura Municipal de Maracanaú, 2018. Disponível em:

https://www.maracanau.ce.gov.br/restaurante-popular-de-maracanaucomemora-10-anos-de-atividades/. Acesso em: 24 set. 2021.

RIBEIRO, Leomara Floriano et al. A importância da capacitação profissional dos manipuladores dos estabelecimentos alimentícios - um estudo no município de Ivaiporã/PR. In: ENCONTRO NACIONAL DE ENGENHARIA DE PRODUÇÃO, 3., 2010, São Carlos. Anais [...]. São Carlos: [s.n.], 2010.

RIGODANZO, Sandra I. et al. Avaliação das boas práticas de manipuladores, responsabilidades, documentação e registro em cozinhas escolares de Itaqui-RS. Revista de Ciencia y Tecnología, n. 26, p. 53-59, 2016.

Disponível em: https://www.scienceopen.com/document?id=481ca0ea-9cdc4a7f-8c87-ccf004b5bcaa. Acesso em: 24 set. 2021.

SANTOS, Jeane Ferreira dos et al. Conhecimento, atitudes e práticas em segurança alimentar de manipuladores de alimentos em hospitais públicos de Salvador, Bahia. Revista Baiana de Saúde Pública, Salvador, v. 37, p. 35-55, jan./mar. 2013. Suplemento 1.

SILVA JUNIOR, Eneo Alves da Silva. Manual de controle higiênico-sanitário em serviços de alimentação. 6. ed. São Paulo: Varela, 2008. 
SILVA, Rosalina Aparecida da. Ciência do alimento: contaminação, manipulação e conservação dos alimentos. 2012. 37 f. Monografia

(Especialização em Ensino de Ciências) - Universidade Tecnológica Federal do Paraná, 2012.

SOARES, Ana Rosa. Análise da estrutura física de serviços de alimentação localizados na zona sul de João Pessoa-PB. 2015. 50 f. Monografia (Graduação em Nutrição) - Universidade Federal da Paraíba, João Pessoa, 2015. Disponível em:

https://repositorio.ufpb.br/jspui/bitstream/123456789/954/1/ARS22062015.p df. Acesso em: 24 set. 2021.

VALIATI, Mariana et al. Avaliação do conhecimento em higiene de manipuladores de alimentos capacitados para self services de Uberlândia MG. Higiene Alimentar, Uberlândia, v. 30, n. 252 -253, p. 42-46, jan./fev. 2016. 


\section{7}

\section{Direitos da mulher no}

período gravídico-puerperal 


\title{
7 DIREITOS DA MULHER NO PERÍODO GRAVÍDICO-PUERPERAL
}

\author{
Graciane de Oliveira Camurça \\ Daniele Vasconcelos Fernandes Vieira \\ Tatiana Paschoalette Rodrigues Bachur \\ Ana Paula da Silva Morais \\ Marcélid Berto da Costa \\ Franscica Gomes Montesuma
}

\section{Resumo}

Introdução: A mulher ao decidir ser mãe, vivencia o ciclo gravídico-puerperal, período que vai desde a concepção até o pós-parto remoto. $\mathrm{O}$ tema pesquisado justifica-se pela produção nacional disponível ser insuficiente, apesar da importância da temática. Objetivo: Investigar na produção científica vigente, os direitos que protegem as mulheres durante o período gravídico-puerperal. Metodologia: Trata-se de uma pesquisa bibliográfica, de abordagem qualitativa, descritiva e através de publicações que visou investigar na literatura os direitos da mulher no período gravídico-puerperal usando periódicos do período de 2008 a 2017. Utilizou-se o modelo para análise temática de Minayo et al. (2002), que compreende três fases: pré-análise, exploração do material e tratamento dos resultados obtidos e interpretação. Encontrou-se, a partir dos critérios de inclusão e exclusão, 12 artigos. Resultados: Das pesquisas selecionadas, o ano que mais teve publicação foi no ano de 2015 com cinco periódicos. Foram encontrados os seguintes direitos: direito à maternidade; direitos sexuais e reprodutivos; direito à presença do acompanhante de sua escolha; licençamaternidade de 120 a 180 dias; direito a escolha da via de parto; direito a repouso de duas semanas em caso de aborto natural; direito a dois intervalos de 30 minutos para amamentar seu filho até completar seis meses; direito a creche dentro da empresa com ambiente adequado para amamentar seu filho; e direito a estabilidade no trabalho até cinco meses pós-parto. Conclusão: Ao final do estudo observou-se que a produção científica nacional sobre esse tema é insuficiente, principalmente por haver uma grande diversidade entre as mulheres grávidas do nosso país, nem todas tendo seus direitos assegurados, fato esse demonstrado pela situação das mulheres gestantes em privação de liberdade. Todos esses direitos elencados constam na literatura vigente. No entanto, há pouca disseminação dessas informações não alcançando, por vezes, o público-alvo.

Palavras-chave: Cuidados de Enfermagem. Saúde da Mulher. Direitos da Mulher. 


\section{Introdução}

No cenário atual vivenciamos modificações na estrutura familiar, onde a mulher inserida no mercado de trabalho retarda o momento de gestar seus filhos para alcançar metas profissionais. Nesse contexto muitas mulheres necessitam sentir-se amparadas por direitos e políticas criadas para beneficiá-las, mas para isso acontecer é fundamental que haja disseminação nos meios de comunicação, para que possam usufruir da melhor forma possível.

O Decreto-lei $n^{\circ} 5.452$, de $1^{\circ}$ de Maio de 1943, aprova a Consolidação das Leis do Trabalho (CLT), sancionado pelo então presidente Getúlio Vargas (BRASIL, 1943). Popularmente chamada de CLT, rege as relações de trabalho entre empregador e empregado. Ao longo dos anos, desde sua criação, ocorreram modificações com o intuito de acompanhar as recorrentes transformações da sociedade, como a inserção da mulher no mercado de trabalho juntamente com sua qualificação profissional. Para facilitar o entendimento, ela foi fragmentada em temáticas diversas que são: Registro do trabalhador/Carteira de trabalho; Jornada de trabalho; Período de descanso; Férias; Medicina do trabalho; Categorias especiais de trabalhadores; Proteção do trabalho da mulher; Contratos individuais de trabalho; Organização sindical; Convenções coletivas; Fiscalização; Justiça do trabalho e Processo trabalhista (BRASIL, 1943).

A gestação representa um momento sublime de realização pessoal. Porém, nesse período, ocorrem diversas transformações físicas, psicológicas, socioeconômicas e emocionais, deixando, por vezes, a mulher fragilizada. No Brasil, no ano de 2015, nasceram 3.017.668 milhões de crianças, 1.339.673 milhões de parto vaginal e 1.674.058 milhões de parto cesáreo, de acordo com o Sistema de Informação sobre Nascidos Vivos (BRASIL, 2018a).

É possível perceber que a mulher, ao decidir ser mãe, vivencia o ciclo gravídico-puerperal, período que vai desde a concepção até o pós-parto remoto. Para administrar esse momento, buscamos lembrar que o Ministério da Saúde instituiu o pré-natal, assistência de saúde voltada para a mulher no período 
gravídico, com o intuito de diminuir a mortalidade materno-infantil. Recomenda-se para obtenção do sucesso o início no primeiro trimestre com a realização dos exames solicitados em tempo hábil (BRASIL, 2013).

No decorrer da gestação, os profissionais de saúde devem transmitir segurança, esclarecer as dúvidas e fornecer informações a respeito dos direitos e políticas direcionadas nessa fase da vida, como visita puerperal domiciliar o mais breve possível, licença-maternidade, assistência adequada durante o pré-natal, direito de realizar os exames de imagens e laboratoriais pelo Sistema Único de Saúde (SUS), recebimento gratuito das medicações usadas no pré-natal, informações pertinentes para preparar os seios para aleitamento materno exclusivo, orientação precoce sobre planejamento familiar, e principalmente entregar a elas o poder de decisão sobre seu estado de saúde e do seu bebê juntamente com as informações sobre a evolução do trabalho de parto e parto. Durante o pré-natal, as gestantes devem ser preparadas para o enfrentamento do puerpério, período logo após o nascimento do recém-nascido até a recuperação de suas funções reprodutivas (BRASIL, 2013). Dessa forma, os anseios e dificuldades são amenizados.

Nessa fase de maior sensibilidade da mulher devido às mudanças no período da gestação e puerpério pensou-se em humanização do SUS e do parto, sendo implementado o Programa de Humanização no Pré-natal e Nascimento, através da Portaria/GM n 569 de 01/06/2000, com o objetivo de desenvolver atividades de promoção, prevenção e assistência à saúde de gestantes e recémnascidos, promovendo a ampliação do acesso a estas ações (BRASIL, 2000). Ações estas fortalecidas com a criação do Programa Rede Cegonha em 24/06/2011 através da Portaria $\mathrm{n}^{\mathrm{0}} 1.459$, que possui o objetivo de assegurar à mulher o direito ao planejamento reprodutivo e à atenção humanizada à gravidez, ao parto e ao puerpério, assim como à criança o direito ao nascimento seguro e ao desenvolvimento saudáveis (BRASIL, 2011).

A estratégia da Rede Cegonha também objetiva diminuir a crescente taxa de morbimortalidade materno-infantil, garantir acesso aos serviços, acolhimento adequado e resolução para os problemas, em parceria com os 
Estados, o Distrito Federal e os Municípios. O monitoramento e a avaliação dos Centro de Parto Normal (CPN), incluindo-se a produção e os indicadores são de responsabilidade das respectivas Secretarias de Saúde estaduais, distrital e municipais, com acompanhamento técnico periódico do Ministério da Saúde (MS), por meio do Departamento de Ações Programáticas Estratégicas (DAPES)/Secretaria de Atenção à Saúde (SAS)/Ministério da Saúde (MS). A verificação do cumprimento das ações de atenção à saúde definidas para cada Componente da Rede será realizada anualmente pelo Ministério da Saúde, de forma compartilhada com o Conselho Nacional de Secretários de Saúde (CONASS) e Conselho Nacional de Secretarias Municipais de Saúde (CONASEMS) (BRASIL, 2011).

Em caso da não aplicação dos recursos ou do descumprimento, por parte do beneficiário, dos compromissos de qualificação assumidos, os recursos de obras, reformas e equipamentos deverão ser imediatamente devolvidos ao Fundo Nacional de Saúde, acrescidos da correção prevista em lei, cuja determinação decorrerá das fiscalizações promovidas pelos órgãos de controle interno, compreendendo os componentes do Sistema Nacional de Auditoria (SNA) do Sistema Único de Saúde (SUS), em cada nível de gestão, e por órgãos de controle externo. A suspensão do repasse dos recursos financeiros do CPN será determinada se verificado o descumprimento de um ou mais requisitos (BRASIL, 2011).

A Ouvidoria do MS é o setor responsável por receber manifestações como reclamações, denúncias, elogios, críticas e sugestões dos cidadãos quanto aos serviços e atendimentos prestados por determinado órgão. O Departamento de Ouvidoria Geral do SUS (DOGES) recebe as manifestações dos usuários do SUS por meio de vários canais como: carta, internet, telefone e atendimento presencial. Um dos canais para o cidadão entrar em contato com a Ouvidoria é o Disque Saúde 136. Este serviço funciona 24 horas; de segunda-feira a sextafeira, das $8 \mathrm{~h}$ às $20 \mathrm{~h}$, e aos sábados, das $8 \mathrm{~h}$ às $18 \mathrm{~h}$, o cidadão pode falar diretamente com o teleatendente. Fora desses horários, as informações são disponibilizadas pela Unidade de Resposta Audível (URA), com informações gravadas (BRASIL, 
2018b). O prazo de atendimento da manifestação de ouvidoria é de até 15 dias podendo ser prorrogado por mais 15 dias conforme estabelece o Decreto $\mathrm{n}^{\mathrm{o}}$. 30.474/2011 (CEARÁ, 2011). O atendimento das Solicitações de Informação é de até 20 dias podendo ser prorrogado por mais 10 dias conforme estabelece a Lei $\mathrm{n}^{\mathrm{o}} .15 .175 / 2012$ (BRASIL, 2018c).

A humanização proporciona à mulher ser protagonista no parto, fornecendo-lhe o direito de escolha do acompanhante, selecionar os métodos não farmacológicos para alívio da dor, optar pelas posições de sua preferência durante o trabalho de parto e parto.

Apesar do avanço crescente da tecnologia, com as informações sendo disseminadas com velocidade e em grande escala, ainda existem mulheres que desconhecem as leis que protegem a sua saúde. Esse fato impulsiona a ânsia de pesquisar sobre o assunto, a partir da seguinte pergunta norteadora: Quais os direitos da mulher no período gravídico-puerperal?

Durante estágio, como pós-graduanda em Enfermagem Obstétrica, em uma maternidade pública do Município de Fortaleza, foi possível visualizar mulheres com ineficiente conhecimento sobre seus direitos. Isso chama atenção por essa realidade contrastar com os avanços nas Políticas Públicas em saúde e na Legislação brasileira sobre as suas garantias neste ciclo tão complexo e importante experiência da vida. Pretende-se com esta revisão, contribuir com a produção de instrumentos ou materiais de educação em saúde que promovam o empoderamento da mulher e de familiares sobre o suporte que deve receber, em qualquer âmbito, seja da saúde, do trabalho e da educação.

\section{Objetivo}

Investigar, na produção científica vigente, os direitos que protegem as mulheres durante o período gravídico-puerperal. 


\section{Método}

Trata-se de uma pesquisa bibliográfica, de abordagem qualitativa, descritiva que visou investigar na literatura os direitos da mulher no período gravídico-puerperal usando publicações do período de 2008 a 2017.

Segundo Gil (2002), a pesquisa bibliográfica pode ser entendida como um estudo exploratório, posto que tenha a finalidade de proporcionar a familiaridade do aluno com a área de estudo no qual está interessado, bem como sua delimitação. Essa familiaridade é essencial para que o problema seja formulado de maneira clara e precisa. Gil (2002) descreve as etapas desta pesquisa em um processo que envolve: escolha do tema, levantamento bibliográfico preliminar, formulação do problema, elaboração do plano provisório de assunto, busca das fontes, leitura do material, fichamento, organização lógica do assunto e redação do texto.

Quanto à análise temática, objeto da presente sistematização, essa se relaciona “a noção de TEMA [que] está ligada a uma afirmação a respeito de determinado assunto. Ele comporta um feixe de relações e pode ser graficamente representada através de uma palavra, uma frase, um resumo" (MINAYO et al., 2002, p. 208).

Para o levantamento bibliográfico, foi realizado uma busca avançada no período de dezembro de 2017 a janeiro de 2018 na base de dados Biblioteca Virtual em Saúde (BVS), Literatura Latino-Americana e do Caribe em Ciências da Saúde (LILACS) e Scientific Electronic Library Online (SciELO) utilizando as palavras-chaves cuidados de enfermagem, saúde da mulher, direitos da mulher. Como critério de inclusão, foram consideradas publicações nacionais, na língua portuguesa, publicados na íntegra, no período de 2008 a 2017, perfazendo os últimos 10 anos e com conteúdos relacionados ao objetivo deste estudo. Como critério de exclusão, não foram consideradas as publicações duplicadas, estudos de revisões e artigos em que não foi possível aplicar os cruzamentos das palavraschave: cuidados de enfermagem, saúde da mulher, direitos da mulher. 
Para a coleta de dados, utilizou-se como instrumento a pergunta norteadora: Quais os direitos das mulheres no período gravídico-puerperal?

A partir da pergunta norteadora, foi elaborado um checklist contendo os direitos da mulher nesta fase.

No checklist citado acima, podemos destacar os seguintes tópicos a serem abordados: Direito reprodutivo; Estabilidade empregatícia; Ausência do trabalho para realização de exames e consultas; Rompimento do contrato de trabalho mediante risco à gestação; Escolha do acompanhante no momento do parto; Direito de escolher e decidir a melhor posição para o parto; Licençamaternidade; Ausentar-se por determinado intervalo de tempo para amamentar seu filho; Visita domiciliar puerperal; Repouso em caso de aborto não criminoso; Direito à creche para os filhos em idade pré-escolar, no caso das operárias que amamentam.

Após a coleta dos dados, os resultados foram apresentados em quadros nos quais foram organizados os artigos encontrados, autores e instituição de origem, tipo de estudo, ano de publicação e palavras-chave.

Os achados da pesquisa foram agrupados, segundo as categorias temáticas de Minayo et al. (2002) e analisados, conforme a legislação regulamentadora da saúde da mulher com seus respectivos direitos. As categorias temáticas encontradas foram cinco: Direito à maternidade; Estabilidade Empregatícia; Direitos durante o trabalho de parto e parto; Direitos da mulher no puerpério; Aborto.

\section{Resultados e Discussão}

Podemos observar que no período estudado, a produção científica associada aos direitos da mulher no período gravídico-puerperal é deficiente, visto que, ao fim da seleção foram encontrados, a partir dos critérios de inclusão e exclusão, apenas 12 artigos. Essa quantidade de artigos encontrados pode ser devido ao pouco valor atribuído a essa temática, já que muitos consideram um 
assunto subjetivo passível de diferentes interpretações, tornando um direito simples em uma legislação complexa.

Das pesquisas selecionadas, o ano que mais teve publicação foi no ano de 2015 com cinco artigos. Os demais artigos foram publicados nos anos de 2008, 2010, 2011, 2013, 2016 e 2017. Desse modo, encontramos uma publicação em Ponta Grossa-Paraná, uma em Uberaba-Minas Gerais, uma em Maceió, uma em Patos-Paraíba, uma em Salvador-Bahia, duas publicações em São Paulo, duas em Porto Alegre, e três publicações em Brasília; dessa forma temos três publicações do Centro-Oeste, três do Nordeste, duas publicações do Sudeste e duas do Sul.

Também chamamos atenção ao fato de que a maioria das pesquisas retrataram os direitos reprodutivos e ao planejamento familiar, assim como a implantação da Rede Cegonha no ano 2011. Apenas duas pesquisas relataram os direitos da mulher em sistema penitenciário brasileiro que se encontravam em situação de privação de liberdade, mas que devem obter acesso à saúde. 
Quadro 1 - Caracterização dos artigos segundo título, autor, tipo de estudo, ano e descritores ou palavras-chave

\begin{tabular}{|c|c|c|c|c|}
\hline $\mathbf{N}^{\circ}$ & Título & Autor(es) & Tipo de estudo/ano & Palavras-chave \\
\hline 01 & $\begin{array}{l}\text { Vivência de mulheres } \\
\text { em situação de prisão } \\
\text { quanto a assistência } \\
\text { recebida no ciclo } \\
\text { gravídico puerperal }\end{array}$ & $\begin{array}{c}\text { Santos; Gazineu e } \\
\text { Bispo }\end{array}$ & $\begin{array}{c}\text { Pesquisa de campo } \\
\text { exploratória com } \\
\text { abordagem qualitativa } \\
\text { (2017) }\end{array}$ & $\begin{array}{l}\text { Saúde da mulher; } \\
\text { prisões; direitos } \\
\text { humanos; } \\
\text { gestantes; } \\
\text { assistência à saúde }\end{array}$ \\
\hline 02 & $\begin{array}{l}\text { Percepção das mulheres } \\
\text { sobre seus direitos no } \\
\text { ciclo gravídico- } \\
\text { puerperal }\end{array}$ & Rodrigues et al. & $\begin{array}{c}\text { Estudo exploratório, } \\
\text { descritivo, transversal } \\
\text { com abordagem } \\
\text { quantitativa (2016) }\end{array}$ & $\begin{array}{c}\text { Mulheres; } \\
\text { legislação; } \\
\text { conhecimento }\end{array}$ \\
\hline 03 & $\begin{array}{l}\text { O desejo da mulher em } \\
\text { relação à via de parto: } \\
\text { uma revisão de } \\
\text { literatura }\end{array}$ & Silva et al. & $\begin{array}{l}\text { Revisão de literatura, } \\
\text { descritiva (2015) }\end{array}$ & $\begin{array}{c}\text { Humanização; } \\
\text { enfermagem; via de } \\
\text { parto; } \\
\text { empoderamento }\end{array}$ \\
\hline 04 & $\begin{array}{l}\text { Manual de enfermagem } \\
\text { - saúde da mulher }\end{array}$ & $\begin{array}{c}\text { Secretaria da } \\
\text { Saúde de São } \\
\text { Paulo }\end{array}$ & Manual técnico (2012) & \\
\hline 05 & $\begin{array}{l}\text { Educação em saúde no } \\
\text { período gravídico } \\
\text { puerperal com foco no } \\
\text { aleitamento materno }\end{array}$ & $\begin{array}{c}\text { Zarpellon; Ravelli } \\
\text { e Matia }\end{array}$ & $\begin{array}{c}\text { A pesquisa foi } \\
\text { desenvolvida pelo } \\
\text { método observacional } \\
\text { a partir da abordagem } \\
\text { qualitativa descritiva } \\
\text { (2015) }\end{array}$ & $\begin{array}{c}\text { Aleitamento } \\
\text { materno; educação } \\
\text { em saúde; gestante; } \\
\text { puérpera }\end{array}$ \\
\hline 06 & $\begin{array}{l}\text { Direitos da gestante: o } \\
\text { resgate atrelado a } \\
\text { (re)humanização do } \\
\text { parto e do nascimento }\end{array}$ & Vieira & Editorial (2015) & \\
\hline 07 & $\begin{array}{l}\text { O direito à saúde das } \\
\text { mulheres gestantes e } \\
\text { puérperas no Sistema } \\
\text { Penitenciário Feminino } \\
\text { do Distrito Federal }\end{array}$ & Lima & $\begin{array}{c}\text { Esta pesquisa será } \\
\text { dotada de } \\
\text { metodologia mista, } \\
\text { onde trabalharemos } \\
\text { em específico o } \\
\text { levantamento } \\
\text { bibliográfico e } \\
\text { documental de acordo } \\
\text { com seus objetivos } \\
\text { (2015) }\end{array}$ & $\begin{array}{c}\text { Direito à saúde; } \\
\text { população privada } \\
\text { de liberdade; } \\
\text { grupos vulneráveis }\end{array}$ \\
\hline 08 & $\begin{array}{c}\text { Atenção ao pré-natal de } \\
\text { baixo risco }\end{array}$ & $\begin{array}{l}\text { Ministério da } \\
\text { Saúde }\end{array}$ & Manual técnico (2013) & \\
\hline
\end{tabular}




\begin{tabular}{|c|c|c|c|c|}
\hline 09 & $\begin{array}{c}\text { Expectativa das } \\
\text { gestantes em relação ao } \\
\text { parto }\end{array}$ & Ferreira et al. & $\begin{array}{l}\text { Pesquisa de natureza } \\
\text { descritiva com } \\
\text { abordagem qualitativa } \\
\text { (2013) }\end{array}$ & $\begin{array}{c}\text { Gestante; } \\
\text { enfermagem; parto; } \\
\text { pré-natal }\end{array}$ \\
\hline 10 & $\begin{array}{l}\text { Participação da mulher } \\
\text { no processo decisório no } \\
\text { ciclo gravídico- } \\
\text { puerperal: revisão } \\
\text { integrativa do cuidado } \\
\text { de enfermagem }\end{array}$ & Busanello et al. & $\begin{array}{l}\text { Revisão integrativa } \\
(2011)\end{array}$ & $\begin{array}{c}\text { Cuidados de } \\
\text { enfermagem; saúde } \\
\text { da mulher; direitos } \\
\text { da mulher }\end{array}$ \\
\hline 11 & $\begin{array}{l}\text { Cadernos de Atenção } \\
\text { básica: saúde sexual e } \\
\text { saúde reprodutiva }\end{array}$ & Brasil & Manual técnico (2010) & \\
\hline 12 & $\begin{array}{c}\text { Conhecimento de } \\
\text { gestantes atendidas em } \\
\text { Unidades Básicas de } \\
\text { Saúde sobre o direito à } \\
\text { presença do } \\
\text { acompanhante durante o } \\
\text { trabalho de parto }\end{array}$ & Santos et al. & $\begin{array}{c}\text { Estudo descritivo com } \\
\text { abordagem } \\
\text { quantitativa (2008) }\end{array}$ & $\begin{array}{c}\text { Saúde da mulher; } \\
\text { direitos do } \\
\text { paciente; } \\
\text { acompanhamento } \\
\text { de pacientes; parto } \\
\text { humanizado; } \\
\text { trabalho de } \\
\text { parto/psicologia }\end{array}$ \\
\hline
\end{tabular}

Fonte: Elaboração das autoras (2018).

Quanto à metodologia dos estudos analisados, temos os seguintes: Pesquisa de campo exploratória com abordagem qualitativa; Estudo exploratório, descritivo, transversal com abordagem quantitativa; Revisão de literatura, descritiva; Manual técnico; Método observacional a partir da abordagem qualitativa descritiva; Editorial; Metodologia mista, onde trabalharemos em específico o levantamento bibliográfico e documental de acordo com os objetivos; Manual técnico; Pesquisa de natureza descritiva com abordagem qualitativa; Revisão integrativa; Manual técnico; Estudo descritivo com abordagem quantitativa.

Consonante aos achados da revisão que objetivam os direitos da mulher gestante no Brasil, destacam-se, abaixo, o direito à maternidade, estabilidade empregatícia, direitos durante o trabalho de parto e parto, direitos da mulher no puerpério e aborto. 


\section{Direito à maternidade}

Os direitos sexuais e os direitos reprodutivos são Direitos Humanos já reconhecidos em leis nacionais e documentos internacionais. Os direitos, a saúde sexual e a saúde reprodutiva são conceitos desenvolvidos recentemente e representa uma conquista histórica, fruto da luta pela cidadania e pelos Direitos Humanos (BRASIL, 2010).

O direito à vida, à alimentação, à saúde, à moradia, à educação, ao afeto, os direitos sexuais e os direitos reprodutivos são considerados Direitos Humanos fundamentais. Respeitá-los é promover a vida em sociedade, sem discriminação de classe social, de cultura, de religião, de raça, de etnia, de orientação sexual. Para que exista a igualdade de direitos, é preciso respeito às diferenças. Não existe um direito mais importante que o outro. Para o pleno exercício da cidadania, é preciso a garantia do conjunto dos Direitos Humanos (BRASIL, 2010).

A concretização, por meio das políticas públicas, dos princípios de igualdade, respeito às diferenças, promoção do pleno exercício da cidadania é um desafio para os governos dos países que se pautam pelos novos marcos teóricos, políticos e jurídicos no campo dos direitos sexuais e dos direitos reprodutivos (BRASIL, 2010).

Entre as mulheres e, por vezes, também entre os trabalhadores de Enfermagem, não há o entendimento de que, mesmo sendo público e gratuito, o cuidado de qualidade, seguro e respeitoso, é um direito de todos os cidadãos. A cobrança da chefia pelo cumprimento de metas assistências, muitas vezes, faz com que a opinião das mulheres não seja ouvida pelos enfermeiros (BUSANELLO et al., 2011).

No Brasil, em 2002 o Ministério da Saúde lançou o Programa Humanização no Pré-natal e Nascimento (PHPN) tendo como objetivo primordial assegurar a melhoria do acesso, da cobertura e da qualidade do acompanhamento pré-natal, da assistência ao parto e puerpério às gestantes e ao recém-nascido. Este Programa fundamentou-se nos preceitos de que a 
humanização da Assistência Obstétrica e Neonatal é condição primeira para o adequado acompanhamento do parto e do puerpério (VIEIRA, 2015).

A política Humaniza-SUS, propõe uma nova relação entre o usuário do SUS e o profissional que o atenderá. A política estimula a implantação de práticas de humanização e a troca solidária de contribuições entre gestores, profissionais de saúde e usuários (SILVA et al., 2015).

É muito importante que a equipe de atenção básica conheça e oriente a mulher sobre os aspectos legais e os direitos na gestação (BRASIL, 2013). Os profissionais de saúde como um todo devem promover estas orientações às mulheres em todos os serviços públicos e privados, para não desperdiçar a oportunidade de multiplicar informações. A atenção básica por ser a porta de entrada possui maior responsabilidade. Assim, entende-se que o enfermeiro possui um papel importante no resgate do direito das mulheres de participar das decisões e problemáticas que podem advir durante o ciclo gravídico-puerperal (BUSANELLO et al., 2011).

A gestante tem direito ao conhecimento e à vinculação à maternidade, onde receberá assistência no âmbito do Sistema Único de Saúde (Lei n ${ }^{\circ} 11.634$, de 27 de dezembro de 2007) (BRASIL, 2010).

Não se pode esquecer das mulheres privadas de liberdade, pois elas também possuem direitos à saúde e à maternidade, uma vez que recebem visitas íntimas de seus companheiros. A maternidade, mesmo quando desejada, envolve uma mistura de sentimentos e expectativas, os quais se intensificam principalmente quando relacionado às mulheres em situação de prisão, visto que já se encontram sensibilizadas pela condição vigente (SANTOS; GAZINEU; BISPO, 2017).

Segundo a constituição, o acesso à saúde é direito de todos e dever do Estado. Dessa forma, para garantir os direitos da mulher presa, foi instituída a Lei n $n^{\circ} 11.942$, no ano de 2009, que determinou que às gestantes presidiárias fosse assegurado de forma humanizada o acompanhamento médico, principalmente durante o pré-natal e puerpério (BRASIL, 2009 apud SANTOS; GAZINEU; BISPO, 2017). 
Para também fomentar o direito dessa mulher em situação de prisão, em 16 de janeiro de 2014, o Ministério da Justiça, através da Portaria Interministerial $n^{\circ} 210$, instituiu a Política Nacional de Atenção às Mulheres em Situação de Privação de Liberdade e Egressas do Sistema Prisional (PNAMPE), com o objetivo de reformular as práticas do sistema prisional brasileiro, contribuindo para a garantia dos direitos das mulheres nacionais e estrangeiras (BRASIL, 2014a apud SANTOS; GAZINEU; BISPO, 2017).

Esta política define ações que objetivam na garantia dos direitos de saúde de mulheres encarceradas (BRASIL, 2014a apud LIMA, 2015). Em janeiro de 2014 baseada no crescente número da população carcerária foi criada a Política Nacional de Atenção Integral à Saúde das Pessoas Privadas de Liberdade no Sistema Prisional (PNAISP) que incentiva a prática de ações que permitam acesso integral aos serviços de saúde da população carcerária levando em consideração a promoção, prevenção e recuperação da saúde (BRASIL, 2014b apud LIMA, 2015).

Santa Rita (2006 apud LIMA, 2015) traz, em seu estudo intitulado mãe e crianças atrás das grades, em questão o princípio da dignidade humana a importância de alavancar estudo que abordem a gravidez e a maternidade dentro do sistema prisional, isso porque ambos estão relacionados à garantia de direitos sexuais e reprodutivos, bem como ao acesso aos serviços destinados a saúde da mulher.

Os direitos sociais oferecidos às grávidas foram o resultado de uma luta pelas mulheres desenvolvidos a partir da compreensão e necessidade de proteção à gestante e bebê (FUNDO DAS NAÇÕES UNIDAS PARA A INFÂNCIA apud RODRIGUES et al., 2016).

A legislação federal e municipal garante que estas possam receber atendimento em caixas especiais, prioridades na fila de emergências de hospitais, bancos, supermercados, acesso à porta da frente de coletivos e assento preferencial em estabelecimentos e meios de transporte coletivo (FUNDO DAS NAÇÕES UNIDAS PARA A INFÂNCIA, 2011 apud RODRIGUES et al., 2016). 
As mulheres grávidas têm seus direitos reconhecidos e deveriam ser tratadas com prioridade e respeito, porém, é de conhecimento geral que, mesmo existindo reconhecimento formal que dá direitos às mulheres no período grávido-puerperal, os benefícios não são atendidos o suficiente para que seja garantida a cidadania para a mulher gestante (RODRIGUES et al., 2016).

Independente da crença, cultura, religião e desejos dessa mulher, o enfermeiro assim como qualquer outro profissional de saúde deve respeitar todos os direitos legalmente garantidos a esta mulher, nunca realizar ou aplicar a ela uma prática na qual ela não se sinta à vontade, pois isso é caracterizado como desrespeito e desumanidade (SILVA et al., 2015).

\section{Estabilidade empregatícia}

O artigo $7^{\circ}$, inciso II, alínea " $\mathrm{b}$ ", do Ato das Disposições Constitucionais Transitórias garante a toda empregada gestante direito à estabilidade no emprego, desde a confirmação da gravidez até 5 (cinco) meses após do parto. A confirmação da gravidez deve ser atestada por meio do exame laboratorial e médico (BRASIL, 2013).

Isto significa que a gestante não poderá ser dispensada do emprego até 5 meses após o nascimento de seu filho. Caso seja despedida, ela tem direito à indenização correspondente aos salários e às demais vantagens que sejam relativos ao respectivo período. Para tanto, assim que for confirmada a gravidez, a mulher deve informar o fato ao empregador. A comunicação ao empregador se faz mediante a apresentação do exame laboratorial Teste de Gravidez (TIG) e do atestado fornecido pelo médico (BRASIL, 2013).

Sempre que a gestante comparecer às consultas e aos exames, ela terá direito à dispensa do horário de trabalho. O médico deve fornecer atestado para que a empregada possa justificar a falta. Além disso, o artigo 371, $\S 4^{\circ}$, inciso II, da CLT garante à gestante a dispensa do trabalho pelo tempo necessário para a realização das consultas médicas e dos exames complementares inerentes aos cuidados de uma gestação saudável (BRASIL, 2013). 
O artigo 373-A, inciso IV, da CLT proíbe a exigência, pelo empregador, de atestado ou exame, de qualquer natureza, para a comprovação de esterilidade ou gravidez da mulher, na admissão ou para a permanência no emprego. $\mathrm{O}$ médico não deve fornecer atestado com estas finalidades. Por outro lado, o médico poderá fornecer atestado de gravidez da mulher para que esta possa exercer a faculdade de romper o compromisso de um contrato de trabalho, desde que seja prejudicial à gestação, nos termos previstos no artigo 394 da CLT (BRASIL, 2013).

A CF e a CLT garantem direitos às mães trabalhadoras, tais como estabilidade no emprego sendo proibida a demissão sem justa causa desde a confirmação da gravidez até os 5 meses após o parto (RODRIGUES et al., 2016).

Na CLT consta um capítulo dedicado à proteção ao trabalho da mulher. E, neste capítulo, uma seção dedicada exclusivamente à proteção à maternidade que prevê, dentre outras regras gerais aplicadas à mulher gestante, garantia de transferência de função quando as condições de saúde a exigirem, assegurada a retomada da função anteriormente exercida logo após o retorno ao trabalho, bem como dispensa do horário pelo tempo necessário para comparecimento de, no mínimo, seis consultas médicas e demais exames complementares (BRASIL, 2005a apud RODRIGUES et al., 2016).

A empregada que é contratada por tempo determinado não terá direito a estabilidade provisória, visto que não será considerada dispensa arbitrária ou sem justa causa quando ocorrer a extinção de relação de emprego pelo fato do prazo ter se esgotado (SILVA, 2007 apud RODRIGUES et al., 2016).

\section{Direitos durante o trabalho de parto e parto}

Atualmente, o princípio da autonomia defende o direito da gestante em fazer uma escolha entre o parto por via vaginal ou abdominal. Geralmente a escolha da via de parto gera muita discussão entre a equipe de saúde. Rotineiramente a gestante não participa desta discussão, e quando informada, é apenas sobre a decisão médica final. Em muitas vezes não se leva em 
consideração sua aceitação ou não em relação à via de parto (FERRARI, 2009 apud SILVA et al., 2015).

Diante desta perda de protagonismo da mulher, ela é submetida a práticas intervencionistas sem o seu devido consentimento e conhecimento, onde muitas vezes ela é afastada da família e de seus desejos, sendo assim submetida às normas impostas pela determinada instituição, tendo como justificativa ser a melhor assistência para ela (OSAVA, 1997 apud MOURA et al., 2007).

A mãe sabe parir, e o bebê sabe como e quando nascer, sendo importante conhecer, diante das mudanças da contemporaneidade, como a mulher se empodera da escolha sobre a via do parto. Neste sentido, estudos apontam que várias são as causas determinantes e condicionantes desta escolha, sendo que algumas dessas causas não permitem que a escolha de fato ocorra (SILVA et al., 2015).

Medidas de conforto físico e suporte emocional realizados durante o processo de parturição podem reduzir o desconforto e a insegurança sentidos pela parturiente, auxiliando no desencadeamento do parto e diminuindo sua duração, assim como a chance de ocorrência de intervenções (SANTOS et al., 2008).

O conforto físico envolve medidas simples como pegar na mão, caminhar com a parturiente, massagear suas costas, ajudá-la a tomar banho, entre outras. O apoio emocional deve incluir contato visual, incentivo, elogios, fornecimento de informações sobre o trabalho de parto e parto e das possíveis intervenções que podem ser realizadas, entre outros (ENKIN et al., 2005 apud SANTOS et al., 2008).

Destaca-se que o apoio vivenciado pelo acompanhante é positivo e benéfico para a mulher. Os profissionais podem e devem adaptar-se a essa nova realidade no momento do parto (BRÜGGEMANN; OSIS; PARPINELLI, 2007 apud FERREIRA et al., 2013).

Em 2005, foi promulgada pelo Presidente da República Federativa do Brasil a Lei $\mathrm{n}^{\mathrm{o}} 11.108$, que permite a presença de acompanhante para a mulher em trabalho de parto e pós-parto nos hospitais públicos e conveniados como SUS 
(BRASIL, 2005b apud SANTOS et al., 2008). Com a regulamentação, a parturiente passou legalmente a ter o direito de escolher um acompanhante que pode ser o esposo, a mãe, a irmã ou uma amiga para estar presente durante o parto e depois no processo de pós-parto (SANTOS et al., 2008).

A gestante tem direito à acompanhante de sua escolha durante toda sua permanência na maternidade, inclusive durante o parto, independentemente de sexo (BRASIL, 2005).

Confirmando o autor acima, de fato a presença de um acompanhante no momento da dor é extremamente importante, trazendo segurança, confiança e apoio emocional para a parturiente, estando esta muitas vezes mais disposta para suportar a dor e a tensão. É importante ressaltar que esse acompanhante, também, necessita do apoio e orientação dos profissionais de saúde, podendo assim prestar o auxílio que for necessário. A sensibilização da equipe quanto à importância do acompanhante naquele momento para aquela mulher é fundamental. São atitudes simples, mas eficazes que podem influenciar positivamente a realidade da assistência da mãe e seu concepto (MOURA et al., 2007 apud SILVA et al., 2015).

A permissão da presença de acompanhantes durante o processo de parto e pós-parto já é de difícil acesso para as mulheres de maneira geral (levando em consideração mulheres que não estão presas), o que se dirá para as mulheres em privação de liberdade. Isso é evidenciado durante anos de pesquisa, onde se pode comprovar na maioria das pesquisas realizadas com este público-alvo que este direito sempre é negado às mulheres encarceradas que se encontram em processo gravídico-puerperal (LIMA, 2015).

Recentemente, em 2015, o MS e a Agência Nacional de Saúde Suplementar (ANS) propuseram uma mudança no modelo de atenção ao parto, com o incentivo ao parto normal, qualificando os serviços e assim contribuindo na redução de cesáreas desnecessárias e de possíveis eventos adversos decorrentes de um parto mal assistido, seja normal ou cesáreo (VIEIRA, 2015).

Esse fato é consonante com o Decreto aprovado em setembro de 2016, que regulamenta o disposto no art. 199 da Lei $n^{\circ}$ 7.210, de 11 de julho de 1984. 
Este Decreto afirma a proibição da utilização de algemas em mulheres presas durante e após o trabalho de parto, e no trajeto da parturiente entre a unidade prisional e a unidade hospitalar (BRASIL, 2016 apud SANTOS; GAZINEU; BISPO, 2017).

\section{Direitos da mulher no puerpério}

Da mesma forma que a gravidez, o pós-parto - também denominado puerpério - é um período especial na vida de uma mulher e merece algumas considerações específicas (BRASIL, 2013).

Por ocasião do parto, a puérpera tem os direitos de ter a criança ao seu lado em alojamento conjunto, amamentar e receber orientações sobre amamentação (BRASIL, 2013). No momento da alta hospitalar, a puérpera tem o direito de receber orientações sobre quando e onde deverá fazer a consulta de pós-parto e o controle da saúde do bebê. Recomenda-se uma visita domiciliar na primeira semana após a alta do bebê (BRASIL, 2013).

$\mathrm{O}$ artigo $7^{\circ}$, inciso XVII, da CF garante à empregada gestante o direito à licença-maternidade, correspondente a 120 (cento e vinte) dias, após o nascimento de seu filho, sem prejuízo do emprego, dos salários e dos demais benefícios. O médico fornecerá atestado do nascimento, que deverá ser encaminhado ao empregador com a comunicação da data do início do afastamento. A licença-maternidade poderá ocorrer a partir do $8^{\circ}$ mês da gestação. Neste caso, o atestado médico indicará a data do afastamento. Além da licença-maternidade, que é necessária à saúde da mãe e do filho, antes e depois do parto, a gestante tem direito ao período de 2 (duas) semanas para descanso, nos termos previstos no artigo 392, $\S 2^{\circ}$, da CLT. O médico fornecerá atestado depois de verificadas tais condições (BRASIL, 2013).

A licença-maternidade pelo período de 180 dias, antes de sancionada a Lei $\mathrm{n}^{\mathrm{o}}$ 11.770, de 9 de setembro de 2008, vem sendo aplicada em algumas cidades e estados, que estabelecem tal período mediante a aprovação de leis estaduais e municipais. De acordo com a Sociedade Brasileira de Pediatria (SBP), 
vários estados brasileiros aprovaram leis que estendem às servidoras públicas o período de licença-maternidade para 180 dias. Há também vários municípios que aprovaram leis que estendem o referido benefício, mas que também só amparam as servidoras públicas das respectivas cidades, ou seja, o benefício não se estende às trabalhadoras sob o regime da CLT (BRASIL, 2013).

A licença-maternidade é também um benefício a que tem direito a mulher trabalhadora que adota uma criança (RODRIGUES et al., 2016).

As gestantes e puérperas possuem muita preocupação com o retorno ao trabalho antes dos seis meses de vida da criança, necessitando introduzir outros alimentos. O artigo 396 da CLT assegura à mãe o direito a 2 (dois) descansos especiais, de meia hora cada um, durante a jornada de trabalho, para a amamentação de seu filho, até que complete 6 (seis) meses de idade. Caso o bebê necessite de um prolongamento do referido cuidado, o médico fornecerá atestado para que os repousos para a amamentação durante a jornada de trabalho sejam prorrogados, fixando inclusive o respectivo período. A lei também garante que a amamentação do bebê seja em local apropriado dentro da empresa (artigo 400 da CLT) (BRASIL, 2013).

Em relação a esta preocupação tem-se o apoio estabelecido pela CF de 1988, artigo $7^{\circ}$ inciso XVIII, a empregada gestante é assegurada pela licença de 120 dias consecutivos, sem prejuízo do emprego e da remuneração, podendo ter início no primeiro dia do nono mês de gestação, salvo antecipação por prescrição médica. Ainda, pode-se recorrer ao acréscimo para amamentação da criança até que este complete seis meses de idade, neste caso a mulher terá direito, durante a jornada de CLT (BRASIL, 1988 apud ZARPELLON; RAVELLI; MATIA, 2015).

Conciliar a vida profissional com a amamentação não é uma tarefa fácil. Mesmo que a legislação tenha avançado em alguns pontos, como a licença maternidade facultativa de seis meses e o horário destinado à amamentação, a proteção ao direito ao aleitamento da mulher trabalhadora ainda não foi alcançado (ZARPELLON; RAVELLI; MATIA, 2015).

A CF e a CLT garantem direitos às mães trabalhadoras, tais como direito de amamentar durante a jornada normal de trabalho (oito horas), além de 
intervalo regular de refeição e descanso a dois períodos de 30 minutos cada para a amamentação até que o bebê atinja seis meses de vida; toda empresa com mais de 30 mulheres acima dos 16 anos de idade tem que manter local apropriado para as mães assistirem aos filhos no período de amamentação até que estes completem seis meses de idade; caso não tenha creche no local de trabalho poderá ser negociado com que a mulher chegue uma hora depois ou saia uma hora antes; diante de situações especiais este prazo poderá ser prorrogado mediante apresentação de um atestado médico; garantia de creche e pré-escola às crianças de zero a seis anos de idade assegurada e que garante, não só o pleno exercício do direito ao trabalho e reprodutivo dos pais como também educação infantil, assistência adequada e acesso a outros benefícios sociais; salário-família é o benefício ao empregado e trabalhador avulso que tenham salário-decontribuição inferior ou igual a R\$ R \$ 682,50 que comprovem ter filhos menores de 14 anos ou inválidos de qualquer idade (CAMPANHOLE, 1988 apud RODRIGUES et al., 2016).

O acesso e o acompanhamento da mulher no período gravídicopuerperal têm trazido grandes melhorias, o direito das parturientes à presença de acompanhante durante o trabalho de parto, Lei 11.108/2005, parto e pós-parto imediato, e a Rede Cegonha que é um programa que visa garantir o acolhimento da gestante desde a confirmação da gestação até o nascimento do bebê, humanizando a assistência (MAIA, 2011 apud FERREIRA et al., 2013).

Após o parto, é assegurada a mulher gestante que se encontra em privação de liberdade, o direito garantido pela CF de 1988, (Artigo 5º e pela Lei de Execução Penal - LEP (Art.89, Lei 7.210/84) de ficar com o seu bebê durante o período de aleitamento materno. 


\section{Aborto}

No caso de aborto, a mulher tem direito a 2 (duas) semanas de repouso, ficando assegurados seus salários e suas funções exercidas. A prova do abortamento espontâneo faz-se por intermédio do atestado médico oficial, que a empregada deverá encaminhar ao empregador (BRASIL, 2013).

As mulheres possuem direitos garantidos na CLT a atestado médico de duas semanas se sofrem aborto. $\mathrm{O}$ aborto natural pode ser definido como interrupção indesejada da gravidez antes de 20-23 semanas ou quando o produto conceptual eliminado pesar 500 gramas ou menos (BRASIL, 2005a apud RODRIGUES et al., 2016).

\section{Considerações Finais}

As produções científicas nacionais sobre a temática são insuficientes, diante da relevância do assunto estudado. Percebe-se que, ao mesmo tempo em que existe direito trabalhista amplamente divulgado, como a licençamaternidade; temos direitos que não são disseminados para as mulheres, como a creche em ambiente adequado no trabalho para amamentar os filhos e o atestado médico de duas semanas para repouso em caso de aborto natural.

Apesar da criação de direitos e políticas direcionadas as mulheres no período gravídico-puerperal, ainda ocorre desrespeito e violações de direitos nos serviços de saúde. Esse fato fica evidente quando as parturientes e puérperas não recebem informações sobre sua situação de saúde, não tem solicitações atendidas, e não são informadas sobre o direito ao acompanhante de escolha da parturiente. A natureza dos serviços de saúde pode ser pública ou privada, mas o atendimento às usuárias deve ser o mesmo, com qualidade e dignidade independente de classe social, respeitando a essência do ser humano. As mulheres que vivenciam o período gravídico-puerperal preservam lembranças 
que poderão ser positivas ou negativas, dependendo da forma como receberão atendimento.

Os profissionais de saúde mais adequados para auxiliar as mulheres nesse período são as enfermeiras obstetras, que fornecem assistência de enfermagem à mulher em trabalho de parto, tratando essa parturiente com humanização. Estes profissionais possuem qualificação necessária, pois realizam cursos de especialização em enfermagem obstétrica e segue as práticas preconizadas pelo Ministério da Saúde, devendo prestar assistência também às mulheres em privação de liberdade, pois elas também possuem o direito de gestar e parir.

Sugiro com este estudo disseminar conhecimento para grupos de gestante, rodas de conversa, e demais serviços de saúde, sobre os direitos que protegem à mulher no período gravídico-puerperal. Dessa forma, podemos encorajar as mulheres a exigir seus direitos, garantindo proteção das leis e multiplicando informações para outras pessoas. Assim, conseguiremos reduzir os diferentes tipos de violência obstétrica, existente nos estabelecimentos de saúde. 


\section{Referências}

BRASIL. [Constituição (1988)]. Constituição da República Federativa do Brasil de 1988. Brasília, DF: Presidência da República, 1988. Disponível em: http://www.planalto.gov.br/ccivil_03/constituicao/constituicao.htm. Acesso em: 1 set. 2021.

BRASIL. Decreto-Lei n 5452, de $1^{\circ}$ de maio de 1943. Aprova a Consolidação das Leis do Trabalho. Diário Oficial [da] República Federativa do Brasil: seção 1, Brasília, DF, 9 ago. 1943.

BRASIL. Decreto $\mathrm{n}^{\circ} 8.858$, de 26 de setembro de 2016. Regulamenta o disposto no art. 199 da Lei n 7.210, de 11 de julho de 1984 - Lei de Execução Penal.

Diário Oficial [da] República Federativa do Brasil: seção 1, Brasília, DF, 27 set. 2016.

BRASIL. Lei n ${ }^{0} 11.942$, de 28 de maio de 2009. Dá nova redação aos arts. 14, 83 e 89 da Lei no 7.210, de 11 de julho de 1984 - Lei de Execução Penal, para assegurar às mães presas e aos recém-nascidos condições mínimas de assistência. Diário Oficial [da] República Federativa do Brasil: seção 1, Brasília, DF, 29 maio 2009. Disponível em:

http:// www.planalto.gov.br/ccivil_03/_Ato2007-

2010/2009/Lei/L11942.htm\#art1. Acesso em: 1 set. 2021.

BRASIL. Portaria Interministerial no 210, de 16 de janeiro de 2014. Institui a política nacional de atenção às mulheres em situação de privação de liberdade e egressas do sistema prisional, e dá outras providências. Diário Oficial [da]

República Federativa do Brasil: seção 1, Brasília, DF, n. 12, p. 75, 17 jan. 2014a.

BRASIL. Ministério da Saúde. Consolidação das leis do trabalho: CLT dinâmica: desenvolvimento e atualização realizados pelo serviço de gestão normativa e jurisprudencial do Tribunal Regional do Trabalho da $2^{\mathrm{a}}$ Região. São Paulo: Serviço de Gestão Normativa e Jurisprudencial, 2005a.

BRASIL. Ministério da Saúde. DATASUS. Brasília, DF: Ministério da Saúde, 2018a. Disponível em: https://datasus.saude.gov.br/. Acesso em: 9 jan. 2018.

BRASIL. Ministério da Saúde. Política Nacional de Atenção Integral à Saúde das Pessoas Privadas de Liberdade no Sistema Prisional. Brasília, DF:

Ministério da Saúde, 2014b. Disponível em:

http://www.as.saude.ms.gov.br/wp-content/uploads/2016/06/CartilhaPNAISP.pdf. Acesso em: 1 set. 2021. 
BRASIL. Ministério da Saúde. Portal da Saúde. Brasília, DF: Ministério da Saúde, 2018b. Disponível em: https://www.gov.br/saude/pt-br. Acesso em: 31 jan. 2018.

BRASIL. Ministério da Saúde. Secretaria de Atenção à Saúde. Atenção ao prénatal de baixo risco. Brasília, DF: Ministério da Saúde, 2013. 318 p. (Cadernos de atenção básica).

BRASIL. Ministério da Saúde. Secretaria de Atenção à Saúde. Pré-natal e puerpério: atenção qualificada e humanizada: manual técnico. Brasília, DF: Ministério da Saúde, 2005b.

BRASIL. Ministério da Saúde. Secretaria de Atenção à Saúde. Saúde sexual e saúde reprodutiva. Brasília, DF: Ministério da Saúde, 2010. (Cadernos de atenção básica).

BRASIL. Portaria n 2.418/GM, 2 de dezembro de 2005. Regulamenta, em conformidade 158 com o art. $1^{\circ}$ da Lei $n^{\circ} 11.108$, a presença de acompanhante para mulheres em trabalho de parto, parto e pós-parto imediato nos hospitais públicos e conveniados com o Sistema Único de Saúde - SUS. Disponível em: https://bvsms.saude.gov.br/bvs/saudelegis/gm/2005/prt2418_02_12_2005.ht ml. Acesso em: 27 set. 2021.

BRASIL. Portaria $n^{\circ}$ 59, de 1 de junho de 2000. Disponível em:

https://bvsms.saude.gov.br/bvs/saudelegis/gm/2000/prt0569_01_06_2000_re p.html. Acesso em: 1 set. 2021.

BRASIL. Portaria $\mathrm{n}^{\circ} 1.459$, de 24 de junho de 2011. Institui no âmbito do Sistema Único de Saúde - SUS - a Rede Cegonha. Diário Oficial [da] República

Federativa do Brasil: seção 1, Brasília, DF, 27 de jun. de 2011.

BRÜGGEMANN, Odaléa Maria; OSIS, Maria José Duarte; PARPINELLI, Mary Angela. Apoio no nascimento: percepções de profissionais e acompanhantes escolhidos pela mulher. Revista Saúde Pública, São Paulo, v. 41, n. 1, p. 44-52, fev. 2007.

BUSANELLO, Josefine et al. Participação da mulher no processo decisório no ciclo gravídico-puerperal: revisão integrativa do cuidado de enfermagem.

Revista Gaúcha de Enfermagem, Porto Alegre, v. 32, n. 4, p. 807-14, dez. 2011. Disponível em:

https://www.scielo.br/j/rgenf/a/9Cw7dGfxhdqM9Yyc4Rx3Btx/abstract/?lan $\mathrm{g}=\mathrm{pt}$. Acesso em: 5 fev. 2018.

CAMPANHOLE, Adriano; CAMPANHOLE, Hilton B. Consolidação das leis do trabalho e legislação complementar. São Paulo: Atlas, 1988. 
CEARÁ. Decreto n ${ }^{\circ} 30.474$, de 29 de março de 2011. Institui o Sistema de Ouvidoria - SOU, e dá outras providências. Diário Oficial do Estado do Ceará: série 3, Fortaleza, ano 3, n. 61, 30 mar. 2011. Disponível em:

https://www.semace.ce.gov.br/wpcontent/uploads/sites/46/2020/01/DECRETO-N\%C2\%BA30.474-de-29-demar\%C3\%A7o-de-2011-D.O.E-30-de-mar\%C3\%A7o-de-2011.pdf. Acesso em: 1 set. 2021.

ENKIN, Murray et al. Guia para atenção efetiva na gravidez e no parto. 3. ed. Rio de Janeiro: Guanabara Koogan, 2005.

FERRARI, José. A autonomia da gestante e o direito pela cesariana a pedido.

Revista Bioética, v. 17, n. 3, p. 473-495, 2009. Disponível em:

https://revistabioetica.cfm.org.br/index.php/revista_bioetica/article/viewFile /512/513. Acesso em: 1 set. 2021.

FERREIRA, Lúcia Aparecida et al. Expectativa das gestantes em relação ao parto. Revista de Pesquisa Cuidado é Fundamental Online, v. 5, n. 2, p. 36923697, abr./jun. 2013. Disponível em:

http://www.seer.unirio.br/index.php/cuidadofundamental/article/view/205 7/pdf_758. Acesso em: 5 fev. 2018.

FUNDO DAS NAÇÕES UNIDAS PARA A INFÂNCIA. Guia dos direitos da gestante e do bebê. São Paulo: Globo, 2011.

GIL, Antonio Carlos. Como elaborar projetos de pesquisa. 4. ed. São Paulo: Atlas, 2002.

LIMA, Jaqueline Ferreira. $\mathrm{O}$ direito à saúde das mulheres gestantes e puérperas no sistema penitenciário feminino do Distrito Federal. 2015. 62 f. Monografia (Curso de Saúde Coletiva) - Universidade de Brasília, Faculdade de Ceilândia, Brasília, DF, 2015.

MAIA, Mônica Bara. Humanização do parto: política pública, comportamento organizacional e ethos profissional. Cadernos de Saúde Pública, Rio de Janeiro, v. 27, n. 5, p. 1041-1044, maio 2011.

MINAYO, Maria Cecília de Souza et al. A análise de dados em pesquisa qualitativa. In: MINAYO, Maria Cecília de Souza. Pesquisa social: teoria, método e criatividade. 21. ed. Petrópolis: Vozes, 2002.

MOURA, Fernanda Maria de Jesus S. Pires et al. A humanização e a assistência de enfermagem ao parto normal. Revista Brasileira de Enfermagem, v. 60, n. 4, p. 452-455, jul./ago. 2007. Disponível em:

https://www.scielo.br/j/reben/a/wBXGtDrr]99ZNQrDVVrMNHH/abstract/ ?lang=pt. Acesso em: 7 jun. 2015. 
OSAVA, Ruth Hitomi. Assistência ao parto no Brasil: O lugar dos não médicos. 1997. 129 f. Tese (Doutorado em Saúde Pública) - Universidade de São Paulo, São Paulo, 1997.

RODRIGUES, Erta Soraya Ribeiro César et al. Percepção das mulheres sobre seus direitos no ciclo gravídico-puerperal. Revista de Enfermagem UFPE On Line, Recife, v. 10, n. 5, p. 1796-17804, maio 2016.

SÃO PAULO. Secretaria da Saúde. Manual técnico: saúde da mulher nas unidades básicas de saúde. 2. ed. São Paulo: Secretaria da Saúde de São Paulo, 2012.

SANTA RITA, Rosangela Peixoto. Mães e crianças atrás das grades: em questão o princípio da dignidade da pessoa humana. 2006. 162 f. Dissertação (Mestrado em Política Social) - Universidade de Brasília, Brasília, DF, 2006.

SANTOS, Hanna Paula da Silva dos; GAZINEU, Rebeca Cardoso; BISPO, Tânia Christiane Ferreira Bispo. Vivência de mulheres em situação de prisão quanto a assistência recebida no ciclo gravídico puerperal. Revista Enfermagem

Contemporânea, v. 6, n. 2, p. 104-113, out. 2017. Disponível em:

https://www5.bahiana.edu.br/index.php/enfermagem/article/view/1291/10 70. Acesso em: 5 fev. 2018.

SANTOS, Jaqueline de Oliveira et al. Conhecimento de gestantes atendidas em unidades básicas de saúde sobre o direito à presença do acompanhante durante o trabalho de parto. Revista do Instituto de Ciências da Saúde, v. 26, n. 3, p. 294-298, 2008. Disponível em: https:/ / repositorio.unip.br/journal-of-thehealth-sciences-institute-revista-do-instituto-de-ciencias-dasaude/conhecimento-de-gestantes-atendidas-em-unidades-basicas-de-saudesobre-o-direito-a-presenca-do-acompanhante-durante-o-trabalho-de-parto/. Acesso em: 5 fev. 2018.

SILVA, Aarão Miranda da. O direito do trabalho da mulher e a maternidade. São Paulo: Âmbito Jurídico, 2007.

SILVA, Divania Oliveira da et al. O desejo da mulher em relação à via de parto: uma revisão de literatura. Ciências Biológicas e da Saúde, Maceió, v. 3, n. 1, p. 103-114, nov. 2015. Disponível em: https://periodicos.set.edu.br/fitsbiosaude/article/view/2582. Acesso em: 5 fev. 2018. 
VIEIRA, Marisa Reginato. Direitos da gestante: o resgate atrelado a (re)humanização do parto e do nascimento. Ciência \& Saúde, Porto Alegre, v. 8, n. 2, p. 47, maio/ago. 2015. Disponível em:

http://revistaseletronicas.pucrs.br/ojs/index.php/faenfi/article/view/21900/ 1346. Acesso em: 5 fev. 2018.

ZARPELLON, Lidia Dalgollo; RAVELLI, Ana Paula Xavier; MATIA, Graciele de. Educação em saúde no período gravídico puerperal com foco no aleitamento materno. In: CONGRESSO NACIONAL DE EDUCAÇÃO, 12., 2015, São Paulo. Anais [...]. São Paulo: [s.n.], 2015. p. 25781-25790. 
08

Prática meditativa na promoção da saúde de pessoas vivendo com HIV/AIDS: Uma revisão integrativa 


\title{
8 PRÁTICA MEDITATIVA NA PROMOÇÃO DA SAÚDE DE PESSOAS VIVENDO COM HIV/AIDS: UMA REVISÃO INTEGRATIVA
}

\author{
Emanuele Ribeiro Ramos \\ Petronio Silva de Oliveira \\ Daniele Vasconcelos Fernandes Vieira \\ Jeania Lima Oliveira \\ Terezinha Almeida Queiroz \\ Alessandra Luzia Alves do Nascimento Celedônio
}

\section{Resumo}

Objetivo: Analisar as evidências da literatura científica sobre a prática meditativa na promoção da saúde das PVHA. Metodologia: Realizou-se uma revisão integrativa no mês de maio de 2018 nas bases de dados LILACS/BIREME, MEDLINE/PubMed e Scopus, a partir dos seguintes descritores em língua inglesa, combinados pelo operado booleano AND: HIV, Meditation e Therapy. Resultados: A partir dos cruzamentos realizados foram encontrados 30 artigos, sendo selecionados 7, sendo dois retirados da LILACS e cinco da MEDLINE/PubMed. Houve predominância de estudos do tipo ensaio clínico $(n=4)$, publicados no ano de 2017, realizados nos Estados Unidos da América $(n=4)$, disponibilizados em revistas específicas da área de Práticas Integrativas e Complementares em saúde $(n=4)$. As principais evidências da literatura científica sobre a influência positiva da meditação na promoção da saúde de Pessoas vivendo com HIV/Aids (PVHA) no que tange aos seguintes domínios: qualidade de vida, controle de estresse e da depressão, adesão à medicação, crescimento pessoal, imunidade e vitalidade. Conclusão: Identificouse como limitação a realização de busca em apenas três bases de dados, o que impediu a generalização dos resultados. Sugere-se a realização de estudos nacionais com enfoque em tecnologias baseadas na prática meditativa para estimular a promoção da saúde de PVHA.

Palavras-chave: HIV. Meditação. Tratamento. 


\section{Introdução}

Em 2015, havia 2,1 milhões de novas infecções de Vírus da Imunodeficiência Humana (HIV) em todo o mundo, totalizando um total de 36,7 milhões pessoas vivendo com HIV (WORLD HEALTH ORGANIZATION, 2016). No Brasil, de 2007 até junho de 2016, foram notificados no Sistema de Informação de Agravos de Notificação (SINAN), no ano de 2015 foram notificados 32.321 casos de infecção pelo HIV, sendo 2.988 casos na região Norte $(9,2 \%), 6.435$ casos na região Nordeste (19,9\%), 13.059 na região Sudeste $(40,4 \%), 7.265$ na região Sul $(22,5 \%)$ e 2.574 na região Centro-Oeste $(8,0 \%)$. Em relação ao número de óbitos, o coeficiente de mortalidade no Brasil é de 5,7 por 100 mil habitantes (BOLETIM EPIDEMIOLÓGICO AIDS/DST BRASIL, 2016). Esses números mostram que em algumas regiões houve um aumento e em outras um declínio do número de casos notificados no último ano.

Segundo Boletim Epidemiológico da Secretaria da Saúde do Estado do Ceará de 01 de dezembro de 2017, no Ceará de 2007 a 2017, até a Semana Epidemiológica (SE) 46 (de 01/01/17 a 18/11/17) foram notificados no Sinan 6.460 casos de HIV. A taxa de detecção de HIV em adultos no Ceará passou de 1,2 casos por 100 mil habitantes em 2007 para 15,8 em 2016. A taxa de mortalidade por HIV vem se mantendo abaixo da média nacional desde 2007, variando entre 3,0 a 4,4 óbitos por 100 mil habitantes no período.

Considerando os princípios básicos do Sistema Único de Saúde (SUS) descritos na Constituição Federal de 1988, a universalização, a integralidade, a descentralização, a hierarquização e a participação popular, os serviços de Atenção Básica devem ser estruturados para possibilitar o acolhimento, o diagnóstico precoce, a assistência e, quando necessário, o encaminhamento das pessoas com infecções sexualmente transmissíveis (IST), incluindo o HIV (BRASIL, 2006).

A infecção pelo HIV tem sido considerada de caráter crônico evolutivo e potencialmente controlável, desde o surgimento da terapia antirretroviral 
combinada (TARV) e da disponibilização de marcadores biológicos, como os linfócitos CD4+ e a carga viral, para o monitoramento de sua progressão. Tais avanços tecnológicos contribuíram com o aumento da expectativa e da qualidade de vida das pessoas vivendo com HIV/Aids (PVHA) (BRASIL, 2008).

As PVHA recebem são acompanhadas nos Serviços de Atenção Especializada em HIV/Aids por uma equipe multidisciplinar, que tem como objetivo superar o atendimento compartimentalizado, centrado apenas no enfoque médico-clínico. O vínculo estabelecido entre a equipe e o usuário facilita o acompanhamento e a adesão ao serviço, fazendo com que o paciente se sinta mais seguro, respeitado e tenha confiança para expressar suas dúvidas relacionadas ao viver com HIV/Aids (ROMEU et al., 2012). Consoante, as PVHA devem ser acolhidas sem discriminação, participando ativamente do autocuidado, o que facilita a adesão ao tratamento, previne a transmissão do vírus, evita a evolução para aids e reduz a mortalidade pela doença (BRASIL, 2015a).

A condição de viver com o HIV é percebida como potencialmente fatal e estigmatizante, gerando em alguns casos isolamento social e dificuldades no enfrentamento da doença (SEIDL; FAUSTINO, 2014).

Esses problemas afetam a esfera psicossocial e podem desencadear desordens psiquiátricas, sendo a prevalência de ansiedade e depressão superior nas pessoas que vivem com o vírus em comparação com a população geral (ROBERTSON et al., 2014; KAGGE; MARTIN, 2010). Evidenciam-se impactos significativos dessas doenças sobre a qualidade de vida e adesão ao tratamento, repercutindo no aumento da morbimortalidade nesta população (ANDRINOPOULOS et al., 2011; DELORENZE et al., 2010; SIN; DIMATTEO, 2014).

Essa realidade aponta para a necessidade de tecnologias que promovam a saúde mental das pessoas com HIV (NIU et al., 2016), sendo imprescindível a equipe multidisciplinar prestar orientações acerca das estratégias para o controle da ansiedade e depressão, que incluem os grupos de 
autoajuda, o acompanhamento psicológico e terapias complementares (REYCHLER et al., 2017; ROBERTSON et al., 2014; PUPULIN et al., 2016).

No Brasil políticas de orientação quanto ao uso de Práticas Integrativas e Complementares em saúde vêm ganhando espaço nas unidades de saúde em diversos modos de intervenção, com vistas a manter a saúde, prevenir e tratar doenças, em particular as condições crônicas (ORGANIZAÇÃO MUNDIAL DE SAÚDE, 2013). Em 27 março de 2017, a Portaria n 849 incluiu a Arteterapia, Ayurveda, Biodança, Dança Circular, Meditação, Musicoterapia, Naturopatia, Osteopatia, Quiropraxia, Reflexoterapia, Reiki, Shantala, Terapia Comunitária Integrativa e Yoga à Política Nacional de Práticas Integrativas e Complementares (BRASIL, 2017).

Considerando as evidências científicas e o baixo dano potencial, a meditação pode ser indicada como terapia complementar nos casos de diabetes, fibromialgia, hipertensão, doença coronariana, lombalgia crônica, psoríase, câncer de mama, abuso de substâncias e dependência de álcool, HIV, Doença de Alzheimer, dentre outras (NOGUSHI, 2015).

Pesquisas realizadas com praticantes de meditação apontam para inúmeras alterações fisiológicas positivas, tais como: alterações do fluxo sanguíneo encefálico e da atividade eletroencefalográfica, reduções da frequência cardíaca modificações nas concentrações de neurotransmissores, queda do consumo de oxigênio e da produção de gás carbônico, redução da temperatura corporal, aumento no volume sanguíneo, acentuada redução no lactato sanguíneo, variações hormonais, aumento da resistência galvânica da pele, diminuição da resistência vascular (BRASIL, 2015b).

Assim, a meditação pode ser utilizada para abordar problemas sociais e de saúde associados ao viver com HIV/aids, incluindo redução do estresse e alívio dos efeitos colaterais, além de estimular o sistema imunológico (LORENC; ROBINSON, 2013). Com base no impacto positivo da meditação sobre a saúde das PVHA, a presente revisão integrativa pretende responder à seguinte questão de pesquisa: Quais são as evidências da literatura científica sobre a influência da prática meditativa na promoção da saúde de pessoas vivendo com HIV / Aids? 


\section{Objetivo}

Analisar as evidências da literatura científica sobre a prática meditativa na promoção da saúde das PVHA.

\section{Método}

Trata-se de um estudo do tipo revisão integrativa, a qual é baseia-se na análise de pesquisas relevantes que dão suporte para a tomada de decisão e a melhoria da prática clínica, possibilitando a síntese do estado do conhecimento de um determinado assunto, além de apontar lacunas do conhecimento que precisam ser preenchidas com a realização de novos estudos, seguindo padrões para que os leitores consigam visualizar os resultados (MENDES; SILVEIRA; GALVÃO, 2008).

Para a operacionalização dessa revisão integrativa foram utilizadas as cinco etapas descritas a seguir: I) Elaboração da questão norteadora do estudo; II) Segunda etapa - Amostragem ou busca na literatura; III) Categorização dos estudos; IV) Avaliação dos estudos incluídos na pesquisa e V) Interpretação dos resultados (MENDES; SILVEIRA; GALVÃO, 2008).

A elaboração da questão norteadora do estudo foi realizada com base na estratégia PICO, que representa um acrônimo para Paciente (pessoas vivendo com HIV/AIDS), Intervenção (prática meditativa), Comparação (cuidado padrão) e Outcomes - desfecho (promoção da saúde) (SANTOS; PIMENTA; NOBRE, 2007). Assim, a pergunta norteadora da revisão integrativa foi: Quais são as evidências da literatura científica sobre a influência da prática meditativa na promoção da saúde de pessoas vivendo com HIV/Aids?

Após definição do tema ou problema iniciou-se a busca na literatura, em bases de dados da área da saúde ou afins. As bases de dados fornecem acesso a citações e frequentemente a resumos dos estudos publicados na literatura científica. Por sua vez, os periódicos são fóruns de divulgação de avanços e novas 
ideias, provendo aos leitores um mecanismo para contínua atualização em pesquisas sobre várias temáticas.

Foram utilizadas as seguintes bases de dados para a realização da busca: a Literatura Latino-Americana e do Caribe em Ciências da Saúde (LILACS/Bireme), Medical Literature Analysis and Retrievel System Online (MEDLINE/PubMed) e SCOPUS. Para a seleção dos artigos foram utilizados os seguintes descritores controlados cadastrados nos Descritores em Ciências da Saúde (DeCS), combinados a partir do uso do operador booleano AND: HIV, Meditation e Therapy. Foram incluídos artigos científicos disponíveis na íntegra, independentes do idioma, publicados entre 2013 e 2018. Ressalta-se que foram excluídos os editoriais, as dissertações, as teses, revisões, protocolo de revisão, bem como os estudos repetidos ou que não respondiam à questão norteadora. A busca foi realizada durante o mês de maio de 2018.

A partir dos cruzamentos realizados foram encontrados 30 artigos, sendo selecionados 7, sendo dois retirados da LILACS e cinco da MEDLINE/PubMed. Foram excluídos 23 artigos, dentre os quais 8 estavam duplicados, 4 eram revisões, 2 eram protocolos de revisão, e 8 não atendiam a pergunta norteadora por abordarem as seguintes temáticas: neuropatia, transmissão do HIV, atividade física, espiritualidade, terapias alternativas em pessoas com outras doenças crônicas (Fluxograma 1).

A fase de categorização dos estudos envolveu a utilização de um instrumento de coleta de dados, com o objetivo de extrair as informações chaves de cada artigo selecionado. 
Fluxograma 1 - Distribuição dos artigos encontrados, excluídos e selecionados. Fortaleza, Ceará, 2018

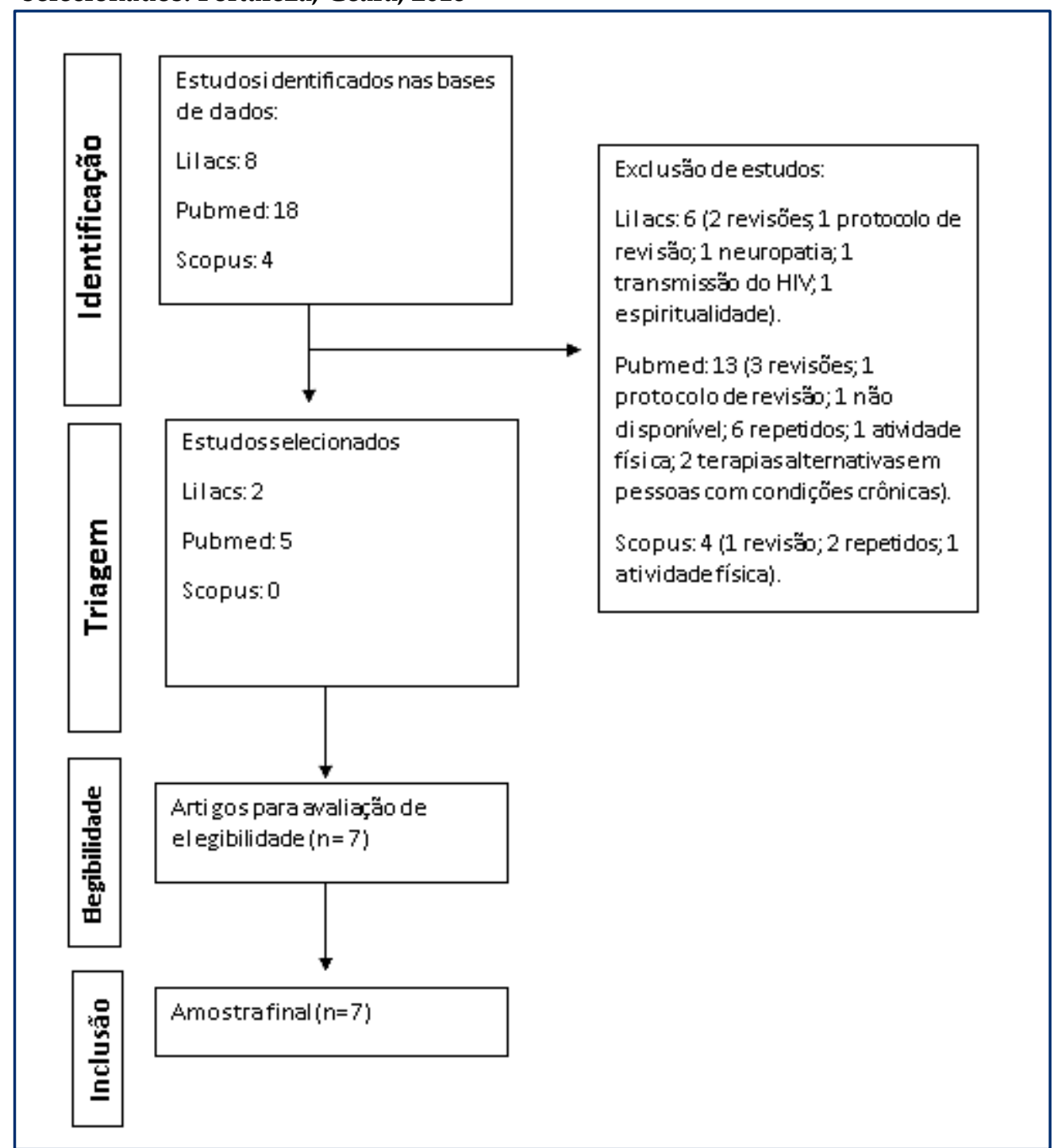

Fonte: Elaboração dos autores.

Utilizou-se a classificação de Melnyk e Fineout-Overholt (2014) para avaliação do nível de evidência dos artigos analisados, a saber: I. Evidências provenientes de revisão sistemática ou metanálise de ensaios clínicos randomizados controlados ou oriundos de diretrizes clínicas baseadas em revisões sistemáticas de ensaios clínicos randomizados controlados; II: Evidências derivadas de pelo menos um ensaio clínico randomizado controlado; III: Evidências obtidas de ensaios clínicos sem randomização; IV: Evidências provenientes de estudos de coorte e caso-controle; V: Evidências originárias de revisão sistemática de estudos descritivos e qualitativos; VI: Evidências 
derivadas de um estudo descritivo ou qualitativo; VII: Evidências oriundas de opinião de autoridades ou relatório de comitês de especialistas.

A análise crítica dos estudos incluídos e teve como finalidade realizar a comparação com o conhecimento teórico, a identificação de conclusões e implicações resultantes da revisão integrativa. Em todas as etapas da revisão foram respeitados os princípios éticos e os direitos autorais, seguindo a legislação brasileira.

\section{Resultados e Discussão}

Dentre os 7 artigos selecionados, observou-se uma maior concentração de estudos publicados no ano de 2017 (n=3), realizados nos Estados Unidos da América $(n=4)$, em revistas específicas da área de Práticas Integrativas e Complementares em saúde $(\mathrm{n}=4)$, disponíveis na MEDLINE/ PubMed (Quadro 1).

O número de publicações disponíveis em um recorte temporal curto evidencia a importância do tema no cenário internacional. As publicações em revistas específicas da área de Práticas Integrativas e Complementares em saúde demonstra que a abordagem das práticas complementares tem alcançado espaço significativo no ambiente acadêmico. Ademais, destaca-se ainda a ausência de pesquisas realizadas no cenário nacional a respeito da prática meditativa no contexto do HIV, o que desperta para a necessidade de realização de estudos com esse enfoque. 
Quadro 1 - Caracterização dos estudos selecionados quanto ao título, autor, ano, país de realização da pesquisa, nome da revista e base de dados. Fortaleza, Ceará, 2018

\begin{tabular}{|c|c|c|c|c|c|}
\hline $\mathbf{N}^{0}$ & Título & Autor/Ano & País & Nome da revista & Base de Dados \\
\hline 1 & $\begin{array}{l}\text { Effect of Integrated Yoga } \\
\text { (IY) on psychological } \\
\text { states and CD4 counts of } \\
\text { HIV-1 infected patients: A } \\
\text { randomized controlled } \\
\text { pilot study }\end{array}$ & $\begin{array}{l}\text { Naoroibam } \\
\text { et al. (2016) }\end{array}$ & Índia & $\begin{array}{l}\text { International } \\
\text { Journal of Yoga }\end{array}$ & LILACS \\
\hline 2 & $\begin{array}{l}\text { A Pilot Feasibility and } \\
\text { Acceptability Study of } \\
\text { Yoga/Meditation on the } \\
\text { Quality of Life and } \\
\text { Markers of Stress in } \\
\text { Persons Living with HIV } \\
\text { Who Also Use Crack } \\
\text { Cocaine }\end{array}$ & $\begin{array}{l}\text { Agarwal; } \\
\text { Kumar e } \\
\text { Lewis (2015) }\end{array}$ & $\begin{array}{l}\text { Estados } \\
\text { Unidos da } \\
\text { América }\end{array}$ & $\begin{array}{l}\text { The Journal of } \\
\text { Alternative and } \\
\text { Complementary } \\
\text { Medicine }\end{array}$ & LILACS \\
\hline 3 & $\begin{array}{l}\text { Prevalence, patterns, and } \\
\text { perceived value } \\
\text { of complementary and } \\
\text { alternative medicine } \\
\text { among HIV patients: a } \\
\text { descriptive study }\end{array}$ & Bahall (2017) & $\begin{array}{l}\text { Trinidad e } \\
\text { Tobago }\end{array}$ & $\begin{array}{l}\text { BMC } \\
\text { Complementary } \\
\text { and Alternative } \\
\text { Medicine }\end{array}$ & MEDLINE/PubMed \\
\hline 4 & $\begin{array}{l}\text { Telephone-Delivered } \\
\text { Mindfulness Training for } \\
\text { People Living with HIV: } \\
\text { A Qualitative } 360^{\circ} \\
\text { Inquiry }\end{array}$ & $\begin{array}{l}\text { Rosen et al. } \\
(2017)\end{array}$ & $\begin{array}{l}\text { Estados } \\
\text { Unidos da } \\
\text { América }\end{array}$ & AIDS and Behavior & MEDLINE/PubMed \\
\hline 5 & $\begin{array}{l}\text { The Effect of a Mind-Body } \\
\text { Intervention on Mental } \\
\text { Health } \\
\text { and Coping Self-Efficacy } \\
\text { in HIV-Infected } \\
\text { Individuals: } \\
\text { A Feasibility Study }\end{array}$ & $\begin{array}{l}\text { Rodkjaer et } \\
\text { al. (2017) }\end{array}$ & Dinamarca & $\begin{array}{l}\text { The Journal of } \\
\text { Alternative and } \\
\text { Complementary } \\
\text { Medicine }\end{array}$ & MEDLINE/PubMed \\
\hline 6 & $\begin{array}{l}\text { The Feasibility of a } \\
\text { Holistic Wellness } \\
\text { Program } \\
\text { for HIV/AIDS Patients } \\
\text { Residing in a } \\
\text { Voluntary Inpatient } \\
\text { Treatment Program }\end{array}$ & $\begin{array}{l}\text { Morgan et al. } \\
(2014)\end{array}$ & $\begin{array}{l}\text { Estados } \\
\text { Unidos da } \\
\text { América }\end{array}$ & $\begin{array}{l}\text { Journal of Holistic } \\
\text { Nursing }\end{array}$ & MEDLINE/PubMed \\
\hline 7 & $\begin{array}{l}\text { Effects of behavioral stress } \\
\text { reduction Transcendental } \\
\text { Meditation } \\
\text { intervention in Persons } \\
\text { with HIV }\end{array}$ & $\begin{array}{l}\text { Chhatre et al. } \\
\text { (2013) }\end{array}$ & $\begin{array}{l}\text { Estados } \\
\text { Unidos da } \\
\text { América }\end{array}$ & AIDS Care & MEDLINE/PubMed \\
\hline
\end{tabular}

Fonte: Elaboração dos autores.

O tipo de estudo predominante foi o ensaio clínico randomizado ( $\mathrm{n}=$ 4), com consequente predominância do nível de evidência I (n=4). Estiveram envolvidas nos estudos um total de 500 PVHA. Um estudo também envolveu 
profissionais de saúde e defensores do HIV. O principal objetivo foi avaliar o efeito da intervenção baseada na meditação e sua viabilidade entre as PVHA (n =5) (Quadro 2).

A predominância de estudos com nível de evidência I é favorável, pois apresentam evidências de maior confiabilidade. Um fator a ser destacado foi o número reduzido de participantes e o reduzido tempo de seguimento nos ensaios clínicos randomizados, o que foi apontado pelos autores como uma limitação, alertando-se para a necessidade de realizar estudos de maior porte para confirmar os resultados significativos alcançados (NAOROIBAM et al., 2016; AGARWAL; KUMAR; LEWIS, 2015; RODKJAER et al., 2017; CHHATRE et al., 2013). 
Quadro 2 - Caracterização dos estudos selecionados quanto ao objetivo, tipo de estudo, amostra e nível de evidência. Fortaleza, Ceará, 2018

\begin{tabular}{|c|c|c|c|c|c|}
\hline $\mathbf{N}^{0}$ & Título & Objetivo & $\begin{array}{l}\text { Tipo de } \\
\text { estudo }\end{array}$ & Amostra & $\begin{array}{l}\text { Nível de } \\
\text { evidência }\end{array}$ \\
\hline 1 & $\begin{array}{l}\text { Effect of Integrated Yoga } \\
\text { (IY) on psychological } \\
\text { states and CD4 counts of } \\
\text { HIV-1 infected patients: } \\
\text { A randomized controlled } \\
\text { pilot study }\end{array}$ & $\begin{array}{l}\text { Estudar o efeito da } \\
\text { intervenção } \\
\text { integrada de um } \\
\text { mês de ioga (IY) } \\
\text { sobre ansiedade, } \\
\text { depressão e e } \\
\text { contagens de CD4 } \\
\text { em pacientes que } \\
\text { sofrem de infecção } \\
\text { pelo HIV-1. }\end{array}$ & $\begin{array}{l}\text { Ensaio } \\
\text { clínico } \\
\text { randomizado }\end{array}$ & $\begin{array}{l}44 \quad \text { PVHA } \\
\text { (Grupo } \\
\text { Intervenção } \\
\text { Yoga: 22; } \\
\text { grupo } \\
\text { controle: 22) }\end{array}$ & I \\
\hline 2 & $\begin{array}{l}\text { A Pilot Feasibility and } \\
\text { Acceptability Study of } \\
\text { Yoga/Meditation on the } \\
\text { Quality of Life and } \\
\text { Markers of Stress in } \\
\text { Persons Living with } \\
\text { HIV Who Also Use } \\
\text { Crack Cocaine }\end{array}$ & $\begin{array}{lrr}\text { Comparar } & \text { a } \\
\text { viabilidade } & \text { e } \\
\text { aceitabilidade } & \text { de } \\
\text { duas } & \text { sessões } \\
\text { semanais de } & \text { Yoga } \\
\text { de duração de } & 60 \\
\text { minutos } & \text { por } & 2 \\
\text { meses } & \text { com } \\
\text { aquelas } & \text { de } \\
\text { controle } & \text { sem } \\
\text { contato; avaliar os } \\
\text { efeitos } & \text { da } \\
\text { intervenção } & \text { na } \\
\text { qualidade de vida } \\
\text { e } & \text { estresse } \\
\text { percebido r entre } \\
\text { PVHA que } & \text { usam } \\
\text { cocaína/crack }\end{array}$ & $\begin{array}{l}\text { Ensaio } \\
\text { clínico } \\
\text { randomizado }\end{array}$ & $\begin{array}{l}24 \quad \text { PVHA } \\
\text { (Grupo } \\
\text { Intervenção } \\
\text { Yoga: 12; } \\
\text { grupo } \\
\text { controle: } 12 \text { ) }\end{array}$ & I \\
\hline 3 & $\begin{array}{l}\text { Prevalence, patterns, } \\
\text { and perceived value } \\
\text { of complementary and } \\
\text { alternative medicine } \\
\text { among HIV patients: a } \\
\text { descriptive study }\end{array}$ & $\begin{array}{l}\text { Explorar a } \\
\text { prevalência, } \\
\text { padrões e valor } \\
\text { percebido do uso } \\
\text { da medicina } \\
\text { complementar e } \\
\text { alternativa entre } \\
\text { pacientes com HIV }\end{array}$ & $\begin{array}{l}\text { Transversal } \\
\text { de } \\
\text { abordagem } \\
\text { quantitativa }\end{array}$ & 342 PVHA & VI \\
\hline 4 & $\begin{array}{l}\text { Telephone-Delivered } \\
\text { Mindfulness Training } \\
\text { for People Living with } \\
\text { HIV: A Qualitative } 360^{\circ} \\
\text { Inquiry }\end{array}$ & \begin{tabular}{l}
\multicolumn{3}{l}{ Buscar } \\
informações sobre \\
a entrega \\
telefônica \\
treinamento de \\
atenção plena para \\
PVHA antes de \\
um teste de \\
intervenção \\
planejado.
\end{tabular} & $\begin{array}{l}\text { Descritivo, } \\
\text { de } \\
\text { abordagem } \\
\text { qualitativa }\end{array}$ & $\begin{array}{l}25 \text { pessoas } \\
\text { (PVHA, } \\
\text { profissionais } \\
\text { de saúde e } \\
\text { defensores } \\
\text { do HIV) }\end{array}$ & VI \\
\hline 5 & $\begin{array}{l}\text { The Effect of a Mind- } \\
\text { Body Intervention on } \\
\text { Mental Health }\end{array}$ & $\begin{array}{lr}\text { Desenvolver } & \mathrm{e} \\
\text { validar } & \text { uma } \\
\text { intervenção } & \\
\text { mente-corpo } & \text { para }\end{array}$ & $\begin{array}{l}\text { Ensaio } \\
\text { clínico } \\
\text { randomizado }\end{array}$ & $\begin{array}{l}30 \text { PVHA } \\
\text { (Grupo } \\
\text { Intervenção }\end{array}$ & I \\
\hline
\end{tabular}




\begin{tabular}{|c|c|c|c|c|c|}
\hline & $\begin{array}{l}\text { and Coping Self-Efficacy } \\
\text { in HIV-Infected } \\
\text { Individuals: } \\
\text { A Feasibility Study }\end{array}$ & $\begin{array}{lr}\text { melhorar } & \text { as } \\
\text { estratégias de } \\
\text { autoeficácia de } \\
\text { enfrentamento e } \\
\text { aumentar a saúde } \\
\text { mental. }\end{array}$ & & $\begin{array}{l}\text { mente- } \\
\text { corpo: } 15 ; \\
\text { grupo } \\
\text { controle: } 15)\end{array}$ & \\
\hline 6 & $\begin{array}{l}\text { The Feasibility of a } \\
\text { Holistic Wellness } \\
\text { Program } \\
\text { for HIV/AIDS Patients } \\
\text { Residing in a } \\
\text { Voluntary Inpatient } \\
\text { Treatment Program }\end{array}$ & $\begin{array}{l}\text { Criar um bem- } \\
\text { estar holístico } \\
\text { voluntário, com } \\
\text { quatro semanas de } \\
\text { duração, dentro } \\
\text { do programa de } \\
\text { tratamento de } \\
\text { saúde } \\
\text { comportamental } \\
\text { de pacientes } \\
\text { internados. }\end{array}$ & $\begin{array}{l}\text { Descritivo, } \\
\text { de } \\
\text { abordagem } \\
\text { qualitativa }\end{array}$ & 13 PVHA & VI \\
\hline 7 & $\begin{array}{l}\text { Effects of behavioral } \\
\text { stress reduction } \\
\text { Transcendental } \\
\text { Meditation } \\
\text { intervention in Persons } \\
\text { with HIV }\end{array}$ & $\begin{array}{l}\text { Avaliar a } \\
\text { viabilidade da } \\
\text { implementação da } \\
\text { meditação } \\
\text { transcendental } \\
\text { (MT) e seus efeitos } \\
\text { nos desfechos em } \\
\text { PVHA. }\end{array}$ & $\begin{array}{l}\text { Ensaio } \\
\text { clínico } \\
\text { randomizado }\end{array}$ & $\begin{array}{l}22 \text { PVHA } \\
\text { (Grupo } \\
\text { Intervenção } \\
\text { MT: 11; } \\
\text { grupo } \\
\text { controle } \\
\text { alimentação } \\
\text { saudável: } \\
\text { 11) }\end{array}$ & I \\
\hline
\end{tabular}

Fonte: Elaboração dos autores.

As evidências identificadas na literatura científica demonstraram a ótima viabilidade e aceitabilidade da meditação entre as PVHA, com possibilidade de ser incentivada presencialmente ou por meio de acompanhamento telefônico. Com relação aos efeitos positivos da meditação sobre a promoção da saúde das PHVA, essa prática complementar mostrou resultados estatisticamente significativos sobre a qualidade de vida, controle de estresse e da depressão, adesão à medicação, crescimento pessoal, imunidade e vitalidade (Quadro 3).

Os impactos positivos da meditação sobre a promoção da saúde de PVHA convergem com os resultados de uma revisão sistemática de intervenções baseadas em psiconeuroimunologia, que apontou intervenções complementares (ioga, meditação, tai chi, acupuntura, atenção plena, práticas religiosas/espirituais), terapia comportamental cognitiva, coping e exercícios físicos promovem benefícios sobre o HIV, depressão, ansiedade, cicatrização de 
feridas, distúrbios do sono, doenças cardiovasculares e fibromialgia (MORAES et al., 2018).

Por outro lado, os estudos selecionados não evidenciaram impactos da meditação sobre a promoção de comportamentos mais saudáveis e atenuação de comportamentos sexuais de risco, o que demonstra a necessidade de se avaliar esses desfechos em pesquisas futuras. Isso concorda com as evidências científicas já disponíveis (ROSEN et al., 2017).

Diante da influência positiva da meditação, pesquisas que visem explorar as experiências e percepções dos pacientes sobre as terapias mentecorpo e energia são fundamentais para oferecer assistência integral e promover tomadas de decisão compartilhadas sobre opções terapêuticas complementares (BREMNER; BLAKE; STILES, 2015). Dessa forma, o conhecimento sobre essas práticas por parte das PVHA proporciona o exercício de um papel ativo em sua saúde e controle de sua condição crônica (LORENC; ROBINSON, 2013).

Quadro 3 - Resumo das evidências da literatura científica sobre a influência da meditação sobre a promoção da saúde de PVHA. Fortaleza, Ceará, 2018

\begin{tabular}{|c|c|}
\hline Evidências & $\mathbf{N}^{\circ}$ do artigo \\
\hline $\begin{array}{l}\text { Viabilidade e Aceitabilidade da Meditação } \\
\text { - Alto nível de viabilidade e aceitabilidade da meditação entre as PVHA; } \\
\text { - A meditação tem um formato simples, seguro e barato; } \\
\text { - A meditação pode ser estimulada a partir de acompanhamento por } \\
\text { - telefone; } \\
\text { - Abordagem terapêutica não-farmacológica, não tóxica e não invasiva pode } \\
\text { ser amplamente utilizada em PVHA. }\end{array}$ & $2,4,6$ \\
\hline $\begin{array}{l}\text { Efeitos positivos sobre a promoção da saúde } \\
\text { - Efeitos modestos nas medidas de qualidade de vida entre PVHA que usam } \\
\text { crack; } \\
\text { - Os participantes reconheceram os benefícios potenciais da meditação para o } \\
\text { controle do estresse e melhoria da adesão à medicação de PVHA; } \\
\text { - A meditação trouxe melhoria significativa no risco de depressão, } \\
\text { - autoeficácia de enfrentamento, estresse e crescimento pessoal de PVHA; } \\
\text { A meditação reduz a depressão e melhora a imunidade em adultos } \\
\text { infectados pelo HIV; } \\
\text { A meditação oferece melhora sobre a vitalidade e na qualidade de vida de } \\
\text { PVHA. }\end{array}$ & $1,2,4,5,7$ \\
\hline
\end{tabular}

Fonte: Elaboração dos autores. 


\section{Considerações Finais}

As principais evidências da literatura científica sobre a influência positiva da meditação na promoção da saúde de PVHA no que tange aos seguintes domínios: qualidade de vida, controle de estresse e da depressão, adesão à medicação, crescimento pessoal, imunidade e vitalidade. Portanto, considera-se que o objetivo geral foi alcançado e a questão norteadora respondida. Identificou-se como limitação a realização de busca em apenas três bases de dados, o que impediu a generalização dos resultados. Sugere-se a realização de estudos nacionais com enfoque em tecnologias baseadas na prática meditativa para estimular a promoção da saúde de PVHA. 


\section{Referências}

AGARWAL, Ram P.; KUMAR, Asarsh; LEWIS, John E. A pilot feasibility and acceptability study of yoga/meditation on the quality of life and markers of stress in persons living with HIV who also use crack cocaine. Journal of Alternative and Complementary Medicine, v. 21, n. 3, p. 152-158, 2015.

ANDRINOPOULOS, Katherine et al. Health related quality of life and psychosocial correlates among HIV-infected adolescent and young adult women in the US. AIDS Education and Prevention, v. 23, n. 4, p. 367-381, 2011.

BAHALL, Mandreker. Prevalence, patterns, and perceived value of complementary and alternative medicine among HIV patients: a descriptive study. BMC Complementary and Alternative Medicine, v. 17, n. 1, p. 422, 2017.

BOLETIM EPIDEMIOLÓGICO AIDS/DST BRASIL. Brasília, DF: Ministério da Saúde, jul./set. 2016.

BRASIL. Ministério da Saúde. Cuidado integral às pessoas que vivem com HIV pela atenção básica. Brasília, DF: Ministério da Saúde, 2015a.

BRASIL. Ministério da Saúde. Portaria no 849, de 27 de março de 2017. Inclui a Arteterapia, Ayurveda, Biodança, Dança Circular, Meditação, Musicoterapia, Naturopatia, Osteopatia, Quiropraxia, Reflexoterapia, Reiki, Shantala, Terapia Comunitária Integrativa e Yoga à Política Nacional de Práticas Integrativas e Complementares. Brasília, DF: Ministério da Saúde, 2017. Disponível em: https://bvsms.saude.gov.br/bvs/saudelegis/gm/2017/prt0849_28_03_2017.ht ml. Acesso em: 10 jun. 2018.

BRASIL. Ministério da Saúde. Secretaria de Atenção à Saúde. HIV/Aids, hepatites e outras DST. Brasília, DF: Ministério da Saúde, 2006.

BRASIL. Ministério da Saúde. Secretaria de Atenção à Saúde. Política Nacional de Práticas Integrativas e Complementares no SUS: atitude de ampliação de acesso. 2. ed. Brasília, DF: Ministério da Saúde, 2015b.

BRASIL. Ministério da Saúde. Secretaria de Vigilância em Saúde. Programa Nacional de DST e Aids. Manual de adesão ao tratamento para pessoas vivendo com HIV e Aids. Brasília, DF: Ministério da Saúde, 2008. 
BREMNER, Marie; BLAKE, Barbara; STILES, Cheryl. The experiences of persons living with HIV who participate in mind-body and energy therapies: a systematic review protocol of qualitative evidence. JBI Database of Systematic Reviews and Implementation Reports, v. 13, n. 10, p. 41-49, 2015.

CHHATRE, Sudhema et al. Effects of behavioral stress reduction transcendental meditation intervention in persons with HIV. AIDS Care, v. 25, n. 10, p. 12911297, Oct. 2013.

DELORENZE, Gerald N. et al. Mortality after diagnosis of psychiatric disorders and co-occurring substance use disorders among HIV-infected patients. Aids Patient Care and STDS, v. 24, n. 11, p. 705-712, 2010.

FLORES, Carolina Aita. Terapia cognitivo-comportamental e tratamento psicológico de pacientes com HIV/AIDS. Revista Brasileira de Terapias Cognitivas, Rio de Janeiro, v. 8, n. 1, p. 55-60, jun. 2012.

KAGEE, Ashraf; MARTIN, Lindi. Symptoms of depression and anxiety among a sample of South African patients living with HIV. AIDS Care, v. 22, n. 2, p. 159-165, 2010.

LORENC, Ava; ROBINSON, Nicola. A review of the use of complementary and alternative medicine and HIV: issues for patient care. AIDS Care STDS, v. 27, n. 9, p. 503-510, 2013.

MELNYK, Bernadette Mazurek; FINEOUT-OVERHOLT, Ellen. Evidence-based practice in nursing \& healthcare: a guide to best practice. Philadelphia: Lippincott Williams \& Wilkins, 2014.

MENDES, Karina Dal Sasso; SILVEIRA, Renta Cristina de Campos Pereira; GALVÃO, Cristina Maria. Revisão integrativa: método de pesquisa para a incorporação de evidências na saúde e na enfermagem. Texto \& Contexto Enfermagem, v. 17, n. 4, p. 758-764, out./dez. 2008.

MORAES, Lucam J. et al. A systematic review of psychoneuroimmunologybased interventions. Psychology Health \& Medicine, v. 23, n. 6, p. 635-652, 2018.

MORGAN, Vanessa. The feasibility of a holistic wellness program for $\mathrm{HIV} / \mathrm{AIDS}$ patients residing in a voluntary inpatient treatment program. Journal of Holistic Nursing, v. 32, n. 1, p. 54-60, 2014.

NAOROIBAM, Rosy et al. Effect of integrated yoga (IY) on psychological states and CD4 counts of HIV-1 infected patients: a randomized controlled pilot study. International Journal of Yoga, v. 9, n. 1, p. 57-61, 2016. Disponível em: https://pubmed.ncbi.nlm.nih.gov/26865772/. Acesso em: 24 set. 2021. 
NIU, Lu et al. The mental health of people living with HIV in China, 1998-2014: a systematic review. PLoS ONE, v. 11, n. 4, 2016. Disponível em:

https://journals.plos.org/plosone/article?id=10.1371/journal.pone.0153489. Acesso em: 24 set. 2021.

NOGUCHI, Melica Satake. Meditação, saúde coletiva e fonoaudiologia: um diálogo em construção. Distúrbios da Comunicação, São Paulo, v. 27, n. 3, p. 642-653, set. 2015.

ORGANIZAÇÃO MUNDIAL DE SAÚDE. Estrategia de la OMS sobre medicina tradicional: 2014-2023. Genebra: Organização Mundial de Saúde, 2013. Disponível em: https://apps.who.int/iris/handle/10665/95008. Acesso em: 10 jun. 2018.

PUPULIN, Aurea Regina Telles et al. Efeito de exercícios físicos e de lazer sobre os níveis de cortisol plasmático em pacientes com Aids. Revista Brasileira de Ciências do Esporte, v. 38, n. 4, p. 328-333, 2016. Disponível em: https://doi.org/10.1016/j.rbce.2014.04.001. Acesso em: 24 set. 2021.

REYCHLER, Gregory et al. Effects of massage therapy on anxiety, depression, hyperventilation and quality of life in HIV infected patients: a randomized controlled trial. Complementary Therapies in Medicine, v. 32, p. 109-114, Jun. 2017.

ROBERTSON, Kevin et al. Screening for neurocognitive impairment, depression, and anxiety in HIV-infected patients in Western Europe and Canada. AIDS Care, v. 26, n. 12, p. 1555-1561, 2014.

RODKJAER, Lotte Oerneborg et al. The effect of a mind-body intervention on mental health and coping self-efficacy in HIV-infected individuals: a feasibility study. Journal of Alternative Complementary Medicine, v. 23, n. 5, p. 326-330, 2017.

ROMEU Geysa Aguiar et al. Avaliação da adesão à terapia antirretroviral em pacientes portadores de HIV. Revista Brasileira de Farmácia Hospitalar e Serviços de Saúde., v. 3, n. 1, p. 37-41, 2012. Disponível em: https://www.rbfhss.org.br/sbrafh/article/view/116. Acesso em: 24 set. 2021.

ROSEN, Rochelle K. et al. Telephone-delivered mindfulness training for people living with HIV: a qualitative $360^{\circ}$ inquiry. AIDS and Behavior, v. 21, n. 11, p. 3194-3201, 2017. 
SANTOS, Cristina Mamédio da Costa; PIMENTA, Cibeli Andrucioli de Mattos; NOBRE, Moacy Roberto Cuce. A estratégia PICO para a construção da pergunta de pesquisa e busca de evidências. Revista Latino-Americana de Enfermagem, v. 15, n. 3, p. 508-511, 2007.

SEIDL, Eliane Maria Fleury; FAUSTINO, Quintino de Medeiros. Pessoas vivendo com HIV / AIDS: possibilidades de atuação da psicologia. In: SEIDL, Eliane Maria Fleury; MIYAZAKI, Maria Cristina O. Santos (org.). Psicologia da saúde: pesquisa e atuação profissional no contexto de enfermidades crônicas. Curitiba: Juruá, 2014. p. 21-54.

SIN, Nancy L.; DIMATTEO, M. Robin. Depression treatment enhances adherence to antiretroviral therapy: a meta-analysis. Annals of Behavioral Medicine, v. 47, n. 3, p. 259-269, 2014.

WORLD HEALTH ORGANIZATION. Global reports: UNAIDS report on the global AIDS epidemic. Geneva: World Health Organization, 2016. 


\section{9}

Prática da fitoterapla por nutricionistas e

profissionais de saúde no

Sistema Único de Saúde no

Brasill: Uma análise de 10

anos 


\title{
9 PRÁTICA DA FITOTERAPIA POR NUTRICIONISTAS E PROFISSIONAIS DE SAÚDE NO SISTEMA ÚNICO DE SAÚDE NO BRASIL: UMA ANÁLISE DE 10 ANOS
}

\author{
Mítia Paiva Mota \\ Patricia Fernandes da Silveira \\ Daniele Vasconcelos Fernandes Vieira \\ Karlivania Martins Cardoso \\ Layla Wynny Aragão Lima Martins \\ Mayara de Matos Morais Monteiro
}

\section{Resumo}

Objetivo: Levantar na bibliografia a participação dos nutricionistas e profissionais da saúde quanto a Política Nacional de Plantas Medicinais e Fitoterápicos (PNPMF) e verificar quais plantas medicinais e fitoterápicos são mais utilizados e suas formas de uso no Sistema único de Saúde (SUS). Método: A pesquisa foi realizada nas bases de dados: Scientific Eletronic Library Online (SciELO), PubMed e Biblioteca Virtual em Saúde do Ministério da Saúde (BVS/MS), dos últimos 10 anos (2009 a 2019). Resultados: Analisaram-se 32 estudos originais sobre o uso de plantas medicinais e fitoterápicos no SUS. As plantas medicinais mais citadas foram boldo e camomila com 19 (26\%) cada, hortelã $15(21 \%)$ e capim-santo $14(19 \%)$ e os fitoterápicos foram guaco $12(16 \%)$ e isoflavona 2 (3\%). Os principais modos de uso encontrados foram infusão 18 (45\%), decocção $16(40 \%)$, maceração $9(23 \%)$ e xarope $7(18 \%)$. Entre os profissionais prescritores estão o médico $6(19 \%)$, enfermeiro $5(17 \%)$, cirurgiãodentista e nutricionista $2(6 \%)$ e farmacêutico 1 (3\%). Conclusão: Com a expansão da prática da fitoterapia no Brasil houve a necessidade de regulamentar profissionais de saúde que possam prescrevê-los, sendo necessário a qualificação dos profissionais e investimentos de pesquisas em fitoterapia.

Palavras-chave: Plantas Medicinais. Fitoterapia. Nutricionista. Profissionais de Saúde. Atenção Primária à Saúde. 


\section{Introdução}

A procura e a prescrição por tratamentos com plantas medicinais e fitoterápicos têm crescido nos últimos anos no Brasil (HASENCLEVER et al., 2017). Até alguns anos, o direito de prescrição era uma exclusividade do profissional médico e médico veterinário. Com a criação da Política Nacional de Plantas Medicinais e Fitoterápicos (PNPMF), publicada em 2006, por meio do Decreto Federal n $n^{\circ} 5813$, de 22 de junho de 2006, outros conselhos profissionais conseguiram regulamentar a prescrição fitoterápica. Assim, cirurgiões dentistas, farmacêuticos, enfermeiros, fisioterapeutas e nutricionistas são os profissionais de saúde habilitados a prescrever (BRASIL, 2006).

O Conselho Federal de Nutricionistas (CFN) pela Resolução n ${ }^{\circ} 680$, de 19 de janeiro de 2021 regulamenta a prescrição de fitoterápicos pelo profissional. O registro é realizado no respectivo Conselho Regional de Nutrição (CRN) com comprovação de curso de pós-graduação latu sensu em nível de especialização em fitoterapia, emitida por instituição de ensino superior reconhecida pelo Ministério da Educação, com no mínimo 200 horas de disciplinas específicas de fitoterapia ou título de Especialista em Fitoterapia ou de Nutrição e Fitoterapia. Além da fitoterapia o profissional é habilitado a prescrever plantas medicinais in natura e drogas vegetais, na forma de infusão, decocção e maceração em água, tais preparações são permitidas a todos os nutricionistas, ainda que sem certificado de pós-graduação em fitoterapia ou título de especialista nessa área (BRASIL, 2021).

Quando a prescrição e a orientação da fitoterapia são realizadas por um profissional habilitado, há efeitos benéficos nas condições clínicas como obesidade, moderador de apetite, ansiedade, compulsão, insônia, dispepsia, retenção hídrica, constipação, diarreia, má digestão e hepatoprotetor (SIQUEIRA; MARTINS, 2018). 


\section{Objetivo}

Realizar um levantamento bibliográfico sobre a participação dos nutricionistas e profissionais da saúde quanto a PNPMF, verificar quais plantas medicinais e fitoterápicos mais utilizados e suas formas de uso Sistema único de Saúde (SUS).

\section{Método}

Realizou-se um levantamento bibliográfico com o tema central plantas medicinais e fitoterápicos no Sistema Único de Saúde (SUS) no Brasil. A pesquisa foi realizada nas bases de dados Scientific Eletronic Library Online (SciELO), PubMed e Biblioteca Virtual em Saúde do Ministério da Saúde (BVS/MS), de setembro a dezembro de 2019. Foram utilizadas combinações de palavras-chave e descritores tais como plantas medicinais, fitoterapia, nutricionista, atenção básica e sistema único de saúde, nos idiomas português, inglês e espanhol, dos últimos 10 anos (2009 a 2019), em artigos científicos.

Inicialmente, avaliou-se os títulos, seguido da leitura dos resumos e, posteriormente, a leitura na íntegra dos estudos. Identificou-se 259 artigos originais nas buscas realizadas. Foram selecionados somente os estudos originais e os critérios para a escolha dos artigos foram, estudos realizados no serviço público e no SUS.

Foram excluídos estudos de revisão, meta estudo, estudos in vitro ou in vivo, estudos com animais, estudos realizados em laboratórios, domicílios, residências, quintais urbanos, universidade, escola, comunidade quilombola, zona rural, inventários, com foco em espécies, etnobotânicos, etnofarmacológicos, etnodirigido, estudos não relacionados ao tema, não realizados no SUS, relato de experiência, realizados na rede particular, banner de congresso, analisar formação acadêmica do nutricionista, estudo documental e 
estudos realizados em outros países. Também foram excluídos 117 artigos por serem repetidos nas bases de dados.

No total foram selecionadas 142 publicações para análise. Em seguida, excluiu-se pela leitura dos resumos 110 artigos, sendo selecionados 32 para leitura na íntegra.

\section{Resultados}

No Quadro 1 estão descritas as características dos estudos sobre plantas medicinais e fitoterápicos. O Quadro 1 foi organizada de modo que nas colunas estão dados como autor, título, local, objetivo e metodologia organizados por ano crescente de publicação.

Foram identificadas 71 plantas medicinais e 2 fitoterápicos que foram agrupados na Tabela 1. As plantas que apareceram com maior frequência nos artigos foram boldo (Pneumus boldus Molina), boldo nacional e falso boldo (Plectranthus barbatus Andrews) com 19 (26\%), camomila (Matricaria recutita L. e Chamaemelum nobile (L.). ALL) em 19 (26\%), hortelã Mentha spp* (M. crispa, $M$. piperita ou M. villosa) em 15 (21\%) e capim-santo (Cymbopogan citratus Staph) em $14(19 \%)$.

Quanto aos fitoterápicos, o guaco (Mikania glomerata Spreng) teve 12 (16\%) e a isoflavona (Glycine max (L) Merr) com 2 (3\%) foram os citados nos estudos.

Os principais modos de uso indicados pelos profissionais de saúde foram o chá na forma de infusão com 18 (36\%), decocção 16 (32\%), maceração 9 (18\%) e xarope 7 (14\%) foram os de maior frequência. 
Quadro 1 - Características dos estudos sobre plantas medicinais e fitoterápicos na atenção primária no Brasil, (2009 a 2019)

\begin{tabular}{|c|c|c|c|c|}
\hline Autor/ Ano & Título & Local & Objetivo & Metodologia \\
\hline $\begin{array}{l}\text { Rangel e Bragança } \\
\text { (2009) }\end{array}$ & $\begin{array}{l}\text { Representações de } \\
\text { gestantes sobre o uso de } \\
\text { plantas medicinais. }\end{array}$ & $\begin{array}{l}\text { Hospital Universitário Antônio Pedro e } \\
\text { na Policlínica Comunitária Carlos } \\
\text { Antônio da Silva, em Niterói, Estado do } \\
\text { Rio de Janeiro, Brasil, no ano de } 2003 .\end{array}$ & $\begin{array}{l}\text { Analisar representações formadas sobre o } \\
\text { uso de plantas medicinais por gestantes } \\
\text { em tratamento ambulatorial, reunindo } \\
\text { informações que possam auxiliar a } \\
\text { compreender, estudar e discutir esse uso }\end{array}$ & Qualitativa \\
\hline $\begin{array}{l}\text { Oliveira; Oliveira e } \\
\text { Andrade (2010) }\end{array}$ & $\begin{array}{lr}\text { Plantas medicinais } \\
\text { utilizadas na comunidade } \\
\text { urbana de Muribeca, } \\
\text { Nordeste do Brasil }\end{array}$ & $\begin{array}{l}\text { Comunidade de Muribeca (Jaboatão do } \\
\text { Guararapes, PE). Centro de Saúde } \\
\text { Alternativa de Muribeca (CESAM). }\end{array}$ & $\begin{array}{l}\text { Realizar um estudo a respeito do } \\
\text { conhecimento e uso de plantas medicinais } \\
\text { na comunidade urbana de Muribeca. }\end{array}$ & $\begin{array}{l}\text { Pesquisa de campo/ } \\
\text { questionários }\end{array}$ \\
\hline Rosa (2011) & $\begin{array}{l}\text { Representações e } \\
\text { intenção de uso da } \\
\text { fitoterapia na atenção } \\
\text { básica à saúde }\end{array}$ & PSF do município de Canoas (RS) & $\begin{array}{l}\text { Conhecer as representações e a utilização } \\
\text { da fitoterapia por parte dos médicos que } \\
\text { atuam na atenção básica no município de } \\
\text { Canoas (RS) e os fatores relacionados à } \\
\text { intenção de uso dessa terapia. }\end{array}$ & $\begin{array}{l}\text { Observacional e de } \\
\text { caráter exploratório; } \\
\text { qualitativa }\end{array}$ \\
\hline Mega et al. (2011) & $\begin{array}{l}\text { Uso de ervas medicinais } \\
\text { por pacientes com asma } \\
\text { grave atendidos em um } \\
\text { centro de referência. }\end{array}$ & $\begin{array}{l}\text { Centro de Referência para Controle de } \\
\text { Asma na Bahia (ProAR), localizado na } \\
\text { cidade de Salvador, nordeste do Brasil. }\end{array}$ & $\begin{array}{l}\text { Avaliar o uso de plantas medicinais entre } \\
\text { tratamentos alternativos utilizados pelos } \\
\text { participantes de um programa de asma e } \\
\text { avaliar sua relação com fatores } \\
\text { econômicos e sociais, além do controle de } \\
\text { doenças. }\end{array}$ & Estudo transversal \\
\hline Badke et al. (2011) & $\begin{array}{llr}\text { Plantas } & \text { medicinais: } & \text { o } \\
\text { saber } & \text { sustentado } & \text { na } \\
\text { prática } & \text { do cotidiano } \\
\text { popular } & & \end{array}$ & $\begin{array}{l}\text { Área de abrangência de USF de } \\
\text { município do RS. }\end{array}$ & $\begin{array}{l}\text { Conhecer o cotidiano popular dos } \\
\text { moradores da comunidade assistida por } \\
\text { uma Unidade de Saúde da Família (USF), } \\
\text { em município do Rio Grande do Sul (RS), } \\
\text { sobre o emprego terapêutico de plantas } \\
\text { medicinais no cuidado à saúde. }\end{array}$ & $\begin{array}{l}\text { Pesquisa qualitativa, } \\
\text { exploratório e descritivo }\end{array}$ \\
\hline $\begin{array}{l}\text { Machado; } \\
\text { Czermainski e Lopes } \\
\text { (2012) }\end{array}$ & $\begin{array}{lr}\text { Percepções } & \text { de } \\
\text { coordenadores } & \text { de } \\
\text { unidades de saúde sobre } \\
\text { a fitoterapia e outras } \\
\text { práticas integrativas e } \\
\text { complementares. }\end{array}$ & $\begin{array}{l}\text { Unidades de saúde (ESF e UBS), em } \\
\text { Porto Alegre }\end{array}$ & $\begin{array}{l}\text { Conhecer o ambiente entre gestores para } \\
\text { a inclusão de fitoterápicos na assistência. }\end{array}$ & $\begin{array}{l}\text { Trata-se de uma série de } \\
\text { casos em que foi } \\
\text { empregada a } \\
\text { metodologia } \\
\text { quantitativa, com dados } \\
\text { obtidos através de }\end{array}$ \\
\hline
\end{tabular}




\begin{tabular}{|c|c|c|c|c|}
\hline & & & & $\begin{array}{l}\text { questionários } \\
\text { estruturados aplicados } \\
\text { aos coordenadores }\end{array}$ \\
\hline $\begin{array}{l}\text { Bruning; Mosegui e } \\
\text { Vianna (2012) }\end{array}$ & $\begin{array}{l}\text { A utilização da fitoterapia } \\
\text { e de plantas medicinais } \\
\text { em unidades básicas de } \\
\text { saúde nos municípios de } \\
\text { Cascavel e Foz do Iguaçu } \\
\text { - Paraná: a visão dos } \\
\text { profissionais de saúde. }\end{array}$ & $\begin{array}{l}\text { Unidades Básicas de Saúde dos } \\
\text { municípios de Cascavel e Foz do } \\
\text { Iguaçu. }\end{array}$ & $\begin{array}{l}\text { Analisou o conhecimento de gestores e } \\
\text { profissionais de saúde que atuam na } \\
\text { atenção primária (APS), sobre fitoterapia }\end{array}$ & Pesquisa de campo \\
\hline Lima et al. (2012) & $\begin{array}{l}\text { Representations and uses of } \\
\text { medicinal plants in elderly } \\
\text { men }\end{array}$ & $\begin{array}{l}\text { Estratégias de Saúde da Família (ESF) } \\
\text { de Dourados, MS, Área urbana: } 26 \\
\text { (ESF) } \\
\text { Área rural: } 09 \text { (ESF), Centros de saúde: } \\
04\end{array}$ & $\begin{array}{l}\text { Conhecer e compreender as } \\
\text { representações sobre o uso de plantas } \\
\text { medicinais por homens idosos }\end{array}$ & $\begin{array}{l}\text { Qualitativa, descritiva e } \\
\text { exploratória }\end{array}$ \\
\hline $\begin{array}{l}\text { Santos; Nunes e } \\
\text { Martins (2012) }\end{array}$ & $\begin{array}{l}\text { Uso empírico de plantas } \\
\text { medicinais para } \\
\text { tratamento de diabetes. }\end{array}$ & $\begin{array}{l}\text { PSF do município de Vitória de Santo } \\
\text { Antão-PE }\end{array}$ & $\begin{array}{l}\text { Descrever a prevalência do uso de plantas } \\
\text { medicinais consideradas } \\
\text { hipoglicemiantes por pacientes diabéticos } \\
\text { no município de Vitória de Santo Antão- } \\
\text { PE e comparar este conhecimento } \\
\text { etnofarmacológico com estudos descritos } \\
\text { na literatura científica. }\end{array}$ & Descritivo transversal \\
\hline Feijó et al. (2012) & $\begin{array}{l}\text { Plantas medicinais } \\
\text { utilizadas por idosos com } \\
\text { diagnóstico de Diabetes } \\
\text { mellitus no tratamento } \\
\text { dos sintomas da doença. }\end{array}$ & Unidade Básica de Saúde de Pelotas-RS & $\begin{array}{l}\text { Investigar as plantas medicinais } \\
\text { utilizadas por idosos assistidos em uma } \\
\text { Unidade Básica de Saúde de Pelotas-RS, } \\
\text { com diagnóstico de Diabetes mellitus, } \\
\text { como terapia complementar no } \\
\text { tratamento dos sintomas da doença. }\end{array}$ & $\begin{array}{l}\text { Qualitativo com caráter } \\
\text { descritivo. }\end{array}$ \\
\hline Souza et al. (2013) & $\begin{array}{lrr}\text { Utilização de } & \text { plantas } \\
\text { medicinais com } & \text { atividade } \\
\text { antimicrobiana } & \text { por } \\
\text { usuários do } & \text { serviço } \\
\text { público de saúde em }\end{array}$ & $\begin{array}{l}\text { Cinco centros de saúde, que atende a } \\
\text { população usuária do SUS, do } \\
\text { município de Campina Grande, } \\
\text { localizados nos bairros: Centro, Bela } \\
\text { Vista, Liberdade, Palmeira e Catolé. }\end{array}$ & $\begin{array}{l}\text { Investigar a utilização de plantas } \\
\text { medicinais, com atividade } \\
\text { antimicrobiana, pela população usuária } \\
\text { do Sistema Único de Saúde, do município } \\
\text { de Campina Grande - PB, com a } \\
\text { finalidade de se conhecer as plantas mais }\end{array}$ & $\begin{array}{l}\text { Estudo descritivo, } \\
\text { transversal com } \\
\text { abordagem quantitativa. }\end{array}$ \\
\hline
\end{tabular}




\begin{tabular}{|c|c|c|c|c|}
\hline & $\begin{array}{l}\text { Campina } \quad \text { Grande } \\
\text { Paraíba }\end{array}$ & & $\begin{array}{l}\text { utilizadas por esta população, o que } \\
\text { favorecerá os profissionais de saúde na } \\
\text { elaboração de uma possível relação } \\
\text { municipal de plantas medicinais, com } \\
\text { eficácia, segurança e qualidade. }\end{array}$ & \\
\hline $\begin{array}{l}\text { Souza Maria et al. } \\
\text { (2013) }\end{array}$ & \begin{tabular}{|lrr|} 
Plantas & \multicolumn{2}{r|}{ medicinais } \\
abortivas & utilizadas por \\
mulheres de & UBS: \\
etnofarmacologia r e \\
análises cromatográficas \\
por CCD e CLAE
\end{tabular} & $\begin{array}{l}\text { Unidade Básica de Saúde (UBS) que se } \\
\text { localiza na região da Zona Leste de São } \\
\text { Paulo. }\end{array}$ & $\begin{array}{l}\text { Avaliar o índice de consumo de plantas } \\
\text { medicinais por mulheres de uma Unidade } \\
\text { Básica de Saúde (UBS), na tentativa de } \\
\text { identificar quais as espécies mais } \\
\text { frequentemente ingeridas inclusive em } \\
\text { período gestacional. }\end{array}$ & $\begin{array}{l}\text { Pesquisa de campo/ } \\
\text { questionários }\end{array}$ \\
\hline $\begin{array}{lll}\text { Varela } & \text { e } & \text { Azevedo } \\
\text { (2014) } & & \end{array}$ & $\begin{array}{l}\text { Saberes e práticas } \\
\text { fitoterápicas de médicos } \\
\text { na estratégia saúde da } \\
\text { família }\end{array}$ & $\begin{array}{l}\text { ESF do município de Caicó, interior do } \\
\text { Rio Grande do Norte }\end{array}$ & $\begin{array}{l}\text { Investigar o conhecimento e o emprego de } \\
\text { fitoterápicos por médicos na ESF de } \\
\text { Caicó, Rio Grande do Norte, Brasil. }\end{array}$ & $\begin{array}{l}\text { Pesquisa descritiva, com } \\
\text { abordagem qualitativa. }\end{array}$ \\
\hline Lima et al. (2014) & \begin{tabular}{llr}
\multicolumn{2}{l}{ Conhecimento e uso de } \\
plantas medicinais & por \\
usuários de & duas \\
unidades básicas & de \\
saúde & & \\
\end{tabular} & $\begin{array}{l}\text { Duas Unidades de Saúde da Família } \\
\text { localizadas no município de Sinop, } \\
\text { norte do Estado do Mato Grosso. }\end{array}$ & $\begin{array}{l}\text { Verificar o conhecimento e o uso de } \\
\text { plantas medicinais entre os usuários da } \\
\text { área de abrangência de duas Unidades de } \\
\text { Saúde da Família. }\end{array}$ & Quantitativo \\
\hline Lopes et al. (2015) & $\begin{array}{l}\text { Estudo das plantas } \\
\text { medicinais, utilizadas } \\
\text { pelos pacientes atendidos } \\
\text { no programa "Estratégia } \\
\text { saúde da família" em } \\
\text { Maringá, PR, Brasil. }\end{array}$ & $\begin{array}{l}\text { Domicílios atendidos por equipe da } \\
\text { ESF Maringá/PR/Brasil }\end{array}$ & $\begin{array}{l}\text { Verificar a utilização de plantas } \\
\text { medicinais pela comunidade, pertencente } \\
\text { à equipe } 10 \text { da Estratégia Saúde da } \\
\text { Família (ESF) da Unidade Básica de Saúde } \\
\text { (UBS) Pinheiros, em Maringá, Paraná, } \\
\text { Brasil. }\end{array}$ & Pesquisa de campo \\
\hline \begin{tabular}{lll|}
$\begin{array}{l}\text { Defani } \\
(2015)\end{array}$ & e & Oliveira \\
\end{tabular} & $\begin{array}{l}\text { Utilização das plantas } \\
\text { medicinais por diabéticos } \\
\text { do município de } \\
\text { Colorado (PR) }\end{array}$ & $\begin{array}{l}\text { Pacientes diabéticos atendidos pela } \\
\text { Secretaria de Saúde do Município de } \\
\text { Colorado (PR) }\end{array}$ & $\begin{array}{l}\text { Levantar o número de pacientes } \\
\text { diabéticos atendidos pela Secretaria de } \\
\text { Saúde do Município de Colorado (PR) e } \\
\text { avaliar o conhecimento que eles têm sobre } \\
\text { as plantas medicinais. }\end{array}$ & $\begin{array}{l}\text { Pesquisa de campo/ } \\
\text { questionários. }\end{array}$ \\
\hline Colet et al. (2015) & $\begin{array}{l}\text { Uso de plantas } \\
\text { medicinais por usuários } \\
\text { do serviço público de }\end{array}$ & $\begin{array}{l}\text { Serviço Público de Saúde do município } \\
\text { de Ijuí/RS. }\end{array}$ & $\begin{array}{l}\text { Descrever o uso de plantas medicinais por } \\
\text { usuários do Serviço Público de Saúde do } \\
\text { município de Ijuí/RS. }\end{array}$ & Estudo transversal \\
\hline
\end{tabular}




\begin{tabular}{|c|c|c|c|c|}
\hline & $\begin{array}{l}\text { saúde do município de } \\
\text { ljuí/RS. }\end{array}$ & & & \\
\hline Silva et al. (2015) & $\begin{array}{l}\text { Utilização de plantas } \\
\text { medicinais por pessoas } \\
\text { com úlcera venosa em } \\
\text { tratamento ambulatorial }\end{array}$ & $\begin{array}{l}\text { Ambulatório de um hospital público de } \\
\text { um município localizado na região } \\
\text { central do RS, Brasil. }\end{array}$ & $\begin{array}{l}\text { Conhecer a utilização de plantas } \\
\text { medicinais por pessoas com úlcera venosa } \\
\text { acompanhadas no ambulatório de um } \\
\text { hospital público, da região central do RS, } \\
\text { Brasil. }\end{array}$ & $\begin{array}{l}\text { Pesquisa qualitativa, } \\
\text { descritiva. }\end{array}$ \\
\hline $\begin{array}{l}\text { Nascimento Júnior et } \\
\text { al. (2016) }\end{array}$ & $\begin{array}{lr}\text { Avaliação } & \text { do } \\
\text { conhecimento } & \text { e } \\
\text { percepção } & \text { dos } \\
\text { profissionais da estratégia } \\
\text { de saúde da família sobre } \\
\text { o uso de plantas } \\
\text { medicinais e fitoterapia } \\
\text { em Petrolina-PE, Brasil }\end{array}$ & $\begin{array}{l}\text { Unidades da Estratégia de Saúde da } \\
\text { Família situadas na sede e interior do } \\
\text { Município de Petrolina-PE. }\end{array}$ & $\begin{array}{l}\text { Verificar se os profissionais de nível } \\
\text { superior, ligados à Estratégia de Saúde da } \\
\text { Família do Município de Petrolina-PE } \\
\text { percebem a importância, utilização e } \\
\text { indicações de Plantas Medicinais e } \\
\text { Fitoterápicos. }\end{array}$ & $\begin{array}{l}\text { Estudo transversal de } \\
\text { caráter exploratório e } \\
\text { descritivo. }\end{array}$ \\
\hline Araújo et al. (2016) & $\begin{array}{l}\text { Efeitos Teratogênicos e } \\
\text { Abortivos por Gestantes } \\
\text { em uma Cidade no } \\
\text { Nordeste do Brasil. }\end{array}$ & $\begin{array}{l}\text { Unidades Básicas de Saúde da Família } \\
\text { e em uma maternidade pública da } \\
\text { cidade de Campina Grande - PB, na } \\
\text { região Nordeste do Brasil }\end{array}$ & $\begin{array}{l}\text { Verificar o perfil de uso de plantas } \\
\text { medicinais por gestantes em Campina } \\
\text { Grande }\end{array}$ & $\begin{array}{l}\text { Transversal } \\
\text { Quantitativo }\end{array}$ \\
\hline Souza et al. (2016) & $\begin{array}{l}\text { O Processo de trabalho } \\
\text { dos enfermeiros da } \\
\text { atenção primária e a } \\
\text { Política Nacional de } \\
\text { Plantas } \\
\text { Medicinais/Fitoterápicos. }\end{array}$ & $\begin{array}{l}\text { Foi realizado em } 21 \text { municípios: os } \\
\text { quais são monitorados pela } 3^{\circ} \\
\text { Coordenadoria Regional de Saúde } \\
\text { (CRS) do Rio Grande do Sul (RS), com } \\
\text { sede em Pelotas. }\end{array}$ & $\begin{array}{l}\text { Conhecer o processo de trabalho dos } \\
\text { enfermeiros da atenção primária em } \\
\text { relação à Política Nacional de Plantas } \\
\text { Medicinais e Fitoterápicos; e identificar as } \\
\text { possibilidades de viabilização desta } \\
\text { política. }\end{array}$ & $\begin{array}{lll}\text { Estudo de } & \text { abordagem } \\
\text { qualitativa } & \text { do } & \text { tipo } \\
\text { descritivo. } & & \end{array}$ \\
\hline Zeni et al. (2017) & $\begin{array}{l}\text { Utilização de plantas } \\
\text { medicinais como remédio } \\
\text { caseiro na Atenção } \\
\text { Primária em Blumenau, } \\
\text { Santa Catarina, Brasil }\end{array}$ & $\begin{array}{l}\text { Farmácias das unidades de atenção } \\
\text { primária de Blumenau }\end{array}$ & $\begin{array}{l}\text { Avaliar o uso de remédios caseiros na } \\
\text { Atenção Primária no município de } \\
\text { Blumenau e as variáveis que } \\
\text { influenciaram na escolha deste tipo de } \\
\text { terapia pelos usuários. }\end{array}$ & $\begin{array}{l}\text { Estudo epidemiológico } \\
\text { observacional, tipo } \\
\text { seccional, que utilizou } \\
\text { dados obtidos pelo } \\
\text { projeto "Melhoria da } \\
\text { qualidade da assistência } \\
\text { farmacêutica na Atenção }\end{array}$ \\
\hline
\end{tabular}




\begin{tabular}{|c|c|c|c|c|}
\hline & & & & $\begin{array}{ll}\text { Básica do } & \text { SUS, } \\
\text { Blumenau, SC". } & \end{array}$ \\
\hline $\begin{array}{l}\text { Schiavo; Schwambach } \\
\text { e Colet (2017) }\end{array}$ & $\begin{array}{l}\text { Conhecimento sobre } \\
\text { plantas medicinais e } \\
\text { fitoterápicos de agentes } \\
\text { comunitários de saúde de } \\
\text { ljuí/RS }\end{array}$ & $\begin{array}{l}\text { Realizada em uma unidade da } \\
\text { Estratégia de Saúde da Família do } \\
\text { município de Ijuí/RS. }\end{array}$ & $\begin{array}{l}\text { Avaliar o conhecimento sobre plantas } \\
\text { medicinais e fitoterápicos por Agentes } \\
\text { Comunitários de Saúde (ACS) em uma } \\
\text { ESF do Município de Ijuí/RS. }\end{array}$ & $\begin{array}{l}\text { Estudo transversal, } \\
\text { qualitativo. }\end{array}$ \\
\hline Schiavo et al. (2017) & $\begin{array}{l}\text { Conhecimento sobre } \\
\text { plantas medicinais por } \\
\text { mulheres em processo de } \\
\text { envelhecimento }\end{array}$ & $\begin{array}{l}\text { Duas unidades de Estratégias Saúde da } \\
\text { Família (ESF) do município de Ijuí/RS. }\end{array}$ & $\begin{array}{l}\text { Avaliar o conhecimento quanto à espécie } \\
\text { e indicação de plantas medicinais } \\
\text { utilizadas por mulheres em processo de } \\
\text { envelhecimento. }\end{array}$ & $\begin{array}{l}\text { Estudo transversal } \\
\text { quantitativo }\end{array}$ \\
\hline Szerwieski et al. (2017) & $\begin{array}{l}\text { Uso de plantas medicinais } \\
\text { por idosos da atenção } \\
\text { primária. }\end{array}$ & $\begin{array}{l}\text { Quatro Unidades Básicas de Saúde do } \\
\text { município de Itaipulândia (PR). }\end{array}$ & $\begin{array}{l}\text { Verificar o uso de plantas medicinais por } \\
\text { idosos usuários da atenção primária. }\end{array}$ & $\begin{array}{lr}\text { Estudo transversal, } \\
\text { correlacional, analítico e } \\
\text { descritivo, rom } \\
\text { abordagem quantitativa. }\end{array}$ \\
\hline Zampirolli et al. (2017) & $\begin{array}{l}\text { Utilização de } \\
\text { medicamentos e plantas } \\
\text { medicinais por gestantes } \\
\text { atendidas na unidade de } \\
\text { saúde da mulher em } \\
\text { Alegre, ES, Brasil }\end{array}$ & $\begin{array}{l}\text { Unidade de Saúde da Mulher, } \\
\text { localizada no município de Alegre, ES. }\end{array}$ & $\begin{array}{l}\text { Identificar o padrão de consumo de } \\
\text { medicamentos e plantas medicinais das } \\
\text { gestantes atendidas na Unidade Saúde da } \\
\text { Mulher, localizado no município de } \\
\text { Alegre, ES. }\end{array}$ & $\begin{array}{ll}\text { Tipo } & \text { transversal } \\
\text { quantitativo }\end{array}$ \\
\hline Mattos et al. (2018) & $\begin{array}{|lrr|}\text { Plantas } & \text { medicinais } & \text { e } \\
\text { fitoterápicas na } & \text { Atenção } \\
\text { Primária em } & \text { Saúde: } \\
\text { percepção } & \text { dos } \\
\text { profissionais } & \\
\end{array}$ & $\begin{array}{l}\text { Unidades da Estratégia Saúde da } \\
\text { Família (ESF), Blumenau, Santa } \\
\text { Catarina }\end{array}$ & $\begin{array}{l}\text { Identificar conhecimentos e práticas em } \\
\text { relação à prescrição e/ou sugestão de uso } \\
\text { de plantas medicinais e fitoterápicos pelos } \\
\text { profissionais de saúde. }\end{array}$ & $\begin{array}{l}\text { Quantitativo } \\
\text { Transversal }\end{array}$ \\
\hline $\begin{array}{l}\text { Gribner; Rattmann e } \\
\text { Gomes (2018) }\end{array}$ & $\begin{array}{l}\text { Use of industrialized herbal } \\
\text { medicines by patients } \\
\text { attended at the basic health } \\
\text { units in the County of } \\
\text { Pinhais, Paraná, Brazil }\end{array}$ & $\begin{array}{l}\text { Unidade básica de Saúde do município } \\
\text { de Pinhais, Paraná, Brasil }\end{array}$ & $\begin{array}{l}\text { Analisar o uso de fitoterápicos } \\
\text { industrializados por pacientes atendidos } \\
\text { em unidades básicas de saúde do } \\
\text { Município de Pinhais, localizado na } \\
\text { região metropolitana de Curitiba, Paraná, } \\
\text { Brasil. }\end{array}$ & $\begin{array}{l}\text { Quantitativo, } \\
\text { observacional } \\
\text { transversal. }\end{array}$ \\
\hline
\end{tabular}




\begin{tabular}{|c|c|c|c|c|}
\hline $\begin{array}{l}\text { Valverde; Silva } \\
\text { Almeida (2018) }\end{array}$ & $\begin{array}{l}\text { Introdução da Fitoterapia } \\
\text { no SUS: contribuindo com } \\
\text { a Estratégia de Saúde da } \\
\text { Família na comunidade } \\
\text { rural de Palmares, Paty } \\
\text { do Alferes, Rio de Janeiro }\end{array}$ & $\begin{array}{l}\text { Estratégia Saúde da Família (ESF) na } \\
\text { comunidade rural de Palmares. }\end{array}$ & $\begin{array}{l}\text { Valorizar o uso de plantas medicinais na } \\
\text { ESF como instrumento para a promoção } \\
\text { de saúde na comunidade rural da Área de } \\
\text { Proteção Ambiental (APA) de Palmares, } \\
\text { Paty do Alferes. }\end{array}$ & $\begin{array}{l}\text { Estudo exploratório } \\
\text { descritivo de abordagem } \\
\text { quali-quantitativa }\end{array}$ \\
\hline $\begin{array}{l}\text { Oliveira; Mezzomo e } \\
\text { Moraes (2018) }\end{array}$ & $\begin{array}{l}\text { Conhecimento e uso de } \\
\text { plantas medicinais por } \\
\text { usuários de unidades } \\
\text { básicas de saúde na } \\
\text { Região de Colombo, PR. }\end{array}$ & $\begin{array}{l}\text { Realizado em quatro UBS no município } \\
\text { de Colombo, na região metropolitana } \\
\text { de Curitiba, PR. }\end{array}$ & $\begin{array}{l}\text { Avaliar o conhecimento sobre a utilização } \\
\text { de plantas medicinais pela população } \\
\text { frequentadora de Unidades Básicas de } \\
\text { Saúde (UBS) em Colombo, PR. }\end{array}$ & $\begin{array}{l}\text { Estudo do tipo } \\
\text { observacional } \\
\text { transversal }\end{array}$ \\
\hline Virgínio et al. (2018) & $\begin{array}{l}\text { Utilização de plantas } \\
\text { medicinais por pacientes } \\
\text { hipertensos e diabéticos: } \\
\text { estudo transversal no } \\
\text { nordeste brasileiro }\end{array}$ & $\begin{array}{l}\text { Realizado em } 16 \text { Unidades de Atenção } \\
\text { Primária à Saúde (UAPS) e em um } \\
\text { ambulatório especializado pertencente } \\
\text { ao Hospital Universitário Walter } \\
\text { Cantídio, da Universidade Federal do } \\
\text { Ceará, ambos integrados ao SUS e } \\
\text { sediados no município de Fortaleza, } \\
\text { Ceará, Brasil. }\end{array}$ & $\begin{array}{l}\text { Descrever a utilização de plantas } \\
\text { medicinais por pacientes hipertensos } \\
\text { e/ou diabéticos atendidos em unidades } \\
\text { de atenção primária à saúde em um } \\
\text { ambulatório especializado no município } \\
\text { de Fortaleza. }\end{array}$ & $\begin{array}{l}\text { Estudo com abordagem } \\
\text { quantitativa, descritiva, } \\
\text { exploratória } \\
\text { transversal. }\end{array}$ \\
\hline Vargas et al. (2019) & $\begin{array}{l}\text { Uso de plantas com fins } \\
\text { terapêuticos por usuários } \\
\text { de uma unidade pré- } \\
\text { hospitalar pública de } \\
\text { Campos dos Goytacazes, } \\
\text { Rio de Janeiro, Brasil }\end{array}$ & $\begin{array}{l}\text { Unidade pré-hospitalar do distrito de } \\
\text { Travessão, município de Campos dos } \\
\text { Goytacazes, RJ. }\end{array}$ & $\begin{array}{l}\text { Identificar as plantas utilizadas com fins } \\
\text { terapêuticos por usuários de uma unidade } \\
\text { pré-hospitalar pública do município de } \\
\text { Campos dos Goytacazes, Rio de Janeiro, } \\
\text { bem como os modos de preparo e uso, e o } \\
\text { conhecimento deles sobre às } \\
\text { propriedades terapêuticas e os } \\
\text { mecanismos de ação e indicação das } \\
\text { plantas que utilizam. }\end{array}$ & $\begin{array}{l}\text { Estudo de natureza } \\
\text { descritiva e exploratória, } \\
\text { der abordagem } \\
\text { qualitativar }\end{array}$ \\
\hline
\end{tabular}

Fonte: Elaboração das autoras. 
Tabela 1 - Plantas medicinais e fitoterápicos mais prescritos na atenção primária no Brasil, (2009 a 2019)

\begin{tabular}{|c|c|c|c|c|c|}
\hline $\begin{array}{l}\text { Planta Medicinal } \\
\text { (Nome popular) }\end{array}$ & Frequência & $\begin{array}{c}\text { Nome } \\
\text { científico }\end{array}$ & Compêndio & Indicação terapêutica /prescrição/uso & Formas de uso \\
\hline $\begin{array}{l}\text { Alfavaca-branca, alfavacão, } \\
\text { manjericão, alfavaca-cravo e } \\
\text { manjericão-cheiroso }\end{array}$ & 2 & Ocimum gratissimum & RS & $\begin{array}{l}\text { Cisco no olho, antidiarreico, digestivo, antigripal e } \\
\text { hipertensão }\end{array}$ & $\begin{array}{l}\text { Colocar semente no olho, infusão, } \\
\text { banho e xarope }\end{array}$ \\
\hline Alfavaca & 1 & Ocimum basilicum & - & Não cita indicação & Decocção \\
\hline Alcachofra & 4 & Cynara scolymus L. & $\begin{array}{l}\text { RS, FB A e B, } \\
\text { MT, RE }\end{array}$ & $\begin{array}{l}\text { Digestiva, diurética, distúrbios hepáticos, } \\
\text { antioxidante, antiespasmódica; Melhora dos } \\
\text { sintomas da síndrome do intestino irritável. }\end{array}$ & Infusão, decocção e maceração \\
\hline Alecrim & 5 & $\begin{array}{c}\text { Rosmarinus officinalis } \\
\text { L. }\end{array}$ & FB A & $\begin{array}{l}\text { Relaxante muscular, distúrbios intestinais, } \\
\text { emenagoga e cicatrizante }\end{array}$ & Infusão, decocção e maceração \\
\hline Arnica & 2 & Arnica montana & FB A & $\begin{array}{l}\text { Traumas, contusões, torções, edemas devido a } \\
\text { fraturas e torções. Não deve ser aplicada em feridas } \\
\text { abertas }\end{array}$ & Gel e pomada \\
\hline Arruda & 3 & Ruta graveolens & RS & Carminativa e antiespasmódica & Infusão, decocção e maceração \\
\hline $\begin{array}{l}\text { Aroeira, aroeira-vermelha, } \\
\text { aroeira-da-praia, aroeira- } \\
\text { pimenteira ou poivre-rose }\end{array}$ & 3 & $\begin{array}{l}\text { Schinus terebinthifolia } \\
\text { Raddi }\end{array}$ & RS e FB A & $\begin{array}{l}\text { Antimicrobiana, anti-inflamatória e cicatrizante; } \\
\text { Tratamento de cervicites, vaginites e } \\
\text { cervicovaginites; Prurido e antisséptico bucal }\end{array}$ & Decocção \\
\hline Anis-estrelado & 1 & Illicium verum & FB A & Resfriado & Infusão \\
\hline Assa-peixe & 1 & $\begin{array}{l}\text { Vernonia polyanthes } \\
\text { Less }\end{array}$ & FB A & - & Chá \\
\hline Amora & 1 & Rubus brasiliensis & - & Ação diurética, antiespasmódica, laxativa e tônica. & $\begin{array}{l}\text { Infusão, decocção, sumo, tintura, } \\
\text { garrafada, pomada e óleo }\end{array}$ \\
\hline Abacaxi & 1 & Ananas comosus & RS & - & - \\
\hline $\begin{array}{l}\text { Boldo, boldo-do-chile } \mathrm{e} \\
\text { boldo-verdadeiro }\end{array}$ & 16 & Peumus boldus Molina & FB A, MT & $\begin{array}{l}\text { Distúrbios gastrointestinais, antioxidante, } \\
\text { quimiopreventivo e anti-inflamatório, } \\
\text { propriedades colagogas, estimulante hepático e } \\
\text { leve demulcente urinário }\end{array}$ & $\begin{array}{l}\text { Infusão, decocção, sumo, tintura, } \\
\text { garrafada, pomada, óleo, aceração, } \\
\text { xarope, suco, compressa e } \\
\text { comprimido ou cápsula }\end{array}$ \\
\hline
\end{tabular}




\begin{tabular}{|c|c|c|c|c|c|}
\hline $\begin{array}{l}\text { Boldo nacional, falso boldo, } \\
\text { boldo africano, boldo } \\
\text { brasileiro, boldo-da-terra, } \\
\text { boldo-de-jardim, tapete-de- } \\
\text { oxalá, alumã, boldo peludo, } \\
\text { boldo-do-reino e malva } \\
\text { santa }\end{array}$ & 3 & $\begin{array}{l}\text { Plectranthus } \\
\text { barbatus }\end{array}$ & FB A, RS & Antidispéptico e hipotensão & Infusão, decocção e maceração \\
\hline Barbatimão & 2 & $\begin{array}{l}\text { Stryphnodendron } \\
\text { adstringens (Mart.) } \\
\text { Coville }\end{array}$ & $\begin{array}{l}\text { RS, FB A e } \\
\text { MT }\end{array}$ & Cicatrizante & Casca e creme \\
\hline Babosa & 6 & Aloe Vera Mill & $\begin{array}{l}\text { RS, FB A, } \\
\text { MT, RE }\end{array}$ & $\begin{array}{l}\text { Furunculose, cicatrizante, coadjuvante nos casos } \\
\text { de psoríase vulgaris, polpa para queimaduras, } \\
\text { hemorroidas, infecção, antimicrobiana e laxante }\end{array}$ & $\begin{array}{l}\text { Folha (uso tópico); (compressa, } \\
\text { suco) }\end{array}$ \\
\hline Camomila & 19 & $\begin{array}{l}\text { Matricaria } \\
\text { chamomilla L. }\end{array}$ & $\begin{array}{l}\text { RS, FB A e B, } \\
\text { MT }\end{array}$ & $\begin{array}{l}\text { Calmante, ansiedade, anti-inflamatório, para } \\
\text { menstruar/cólicas; processos inflamatórios boca e } \\
\text { gengiva; antimicrobiano e antioxidante; digestão, } \\
\text { dispepsia e flatulência }\end{array}$ & 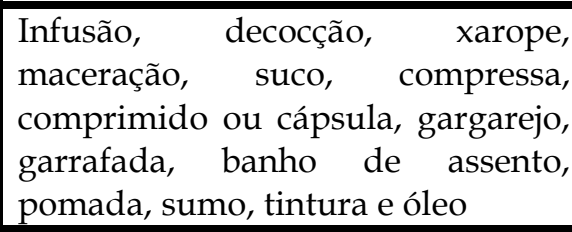 \\
\hline $\begin{array}{l}\text { Capim-santo, capim-limão, } \\
\text { capim-cidró, capim-cidreira } \\
\text { e cidreira }\end{array}$ & 14 & $\begin{array}{l}\text { Cymbopogon citratus } \\
\text { (DC) Stapf }\end{array}$ & FB A & $\begin{array}{l}\text { Calmante, ansiedade, insônia, digestivo, } \\
\text { antiespasmódico, gastroprotetora, antidiarreico, } \\
\text { cólicas intestinais e uterinas, hipotensão arterial, } \\
\text { cardiotônico, depurativo, tensão pré-menstrual, } \\
\text { anti-inflamatório, antialérgico, gripes e resfriados }\end{array}$ & $\begin{array}{l}\text { Decocção, infusão, xarope, ervas } \\
\text { maceradas e mistas, sumos, tinturas, } \\
\text { pomadas, garrafas e óleos }\end{array}$ \\
\hline Cavalinha & 2 & $\begin{array}{l}\text { Equisetum giganteum } \\
\text { L. }\end{array}$ & - & $\begin{array}{l}\text { Problemas renais, antiviral, calmante, digestivo, } \\
\text { gripe e resfriado }\end{array}$ & Infusão, decocção e maceração \\
\hline Chapéu de couro & 1 & $\begin{array}{c}\text { Echinodorus } \\
\text { macrophyllus (Kunth) } \\
\text { Micheli }\end{array}$ & FB A & Depurativo do sangue, diurético e antirreumático & Infusão, decocção e maceração \\
\hline Cáscara- sagrada & 2 & $\begin{array}{l}\text { Rhamnus purshiana } \\
\text { DC. }\end{array}$ & $\begin{array}{l}\text { RS, FB B, } \\
\text { MT, RE }\end{array}$ & Constipação intestinal & $\begin{array}{l}\text { Cápsula, comprimido, extrato seco e } \\
\text { tintura }\end{array}$ \\
\hline Copaíba & 1 & Copaifera langsdorffii & RS, FB A & Anti-inflamatório, antisséptico e cicatrizante & Pomada \\
\hline
\end{tabular}




\begin{tabular}{|c|c|c|c|c|c|}
\hline $\begin{array}{l}\text { Carqueja, carqueja-amarga, } \\
\text { carqueja amargosa, e } \\
\text { carquejinha }\end{array}$ & 8 & Baccharis trimera $L$. & RS, FB A e B & $\begin{array}{l}\text { Anti-inflamatório, antioxidante, } \\
\text { imunomodulatório, antiulcerogênico, citoprotetor } \\
\text { do estômago, efeito hiperglicêmico, } \\
\text { hepatoprotetor, colagogo, digestão, dor de } \\
\text { garganta, diabetes, dor de barriga, dor no peito, } \\
\text { colesterol alto, febre, fígado e tosse }\end{array}$ & Infusão e decocção \\
\hline Caju & $\mathbf{1}$ & $\begin{array}{l}\text { Anacardium } \\
\text { occidentale }\end{array}$ & RS & Anti- diabética & Casca \\
\hline Cimicífuga & 1 & $\begin{array}{l}\text { Cimicifuga racemosa } \\
\text { (L.) Nutt. }\end{array}$ & FB B e MT & Ação terapêutica sobre os sintomas do climatério & Cápsula ou comprimido \\
\hline Confrei & 1 & Symphytum officinale & FB A & - & Tomar e lavar a ferida \\
\hline Canela & 1 & Cinnamomum verum & FB A & Cólica menstrual e diarreia & - \\
\hline Cana do brejo & 1 & Costus spicatus & RS & $\begin{array}{l}\text { Raízes e rizomas: ação diurética e tônica; Suco da } \\
\text { haste fresca: nefrites, sífilis, problemas na bexiga e } \\
\text { diabetes }\end{array}$ & $\begin{array}{l}\text { Decocção (folhas secas, raízes e } \\
\text { sementes) }\end{array}$ \\
\hline Dente de leão & 1 & $\begin{array}{c}\text { Taraxacum officinale } \\
\text { Weber }\end{array}$ & FB A e B & - & Decocção \\
\hline $\begin{array}{l}\text { Erva-cidreira de arbusto e } \\
\text { lípia }\end{array}$ & 9 & Lippia alba (Mill) & FB A e B & $\begin{array}{l}\text { Calmante, ansiolítico, sedativo leve, ansiedade, } \\
\text { insônia, anemia, hipertensão, antidiarreico, } \\
\text { digestivo, antiespasmódico menstrual e } \\
\text { depurativo, flatulências, cólicas abdominais, } \\
\text { distúrbios estomacais e digestivo, antidispéptico, } \\
\text { anti-inflamatório, gripes, resfriados e expectorante }\end{array}$ & $\begin{array}{l}\text { Decocção, infusão, xarope, ervas } \\
\text { maceradas e mistas, suco e } \\
\text { compressa }\end{array}$ \\
\hline $\begin{array}{l}\text { Espinheira-santa } \\
\text { cancorosa }\end{array}$ & 10 & $\begin{array}{l}\text { Maytenus ilicifolia } \\
\text { Mart. }\end{array}$ & $\begin{array}{l}\text { RS, FB A e B, } \\
\text { MT, RE }\end{array}$ & $\begin{array}{l}\text { Dispepsia (distúrbios da digestão), azia, gastrite. } \\
\text { Coadjuvante no tratamento episódico de } \\
\text { prevenção de úlcera em uso de anti-inflamatórios } \\
\text { não esteroidais, furúnculos, diurético, antitumoral, } \\
\text { analgésico e úlcera venosa }\end{array}$ & $\begin{array}{l}\text { Chá, maceração, cápsula, infusão } \\
\text { (folhas frescas), decocção (folhas } \\
\text { secas, raízes e sementes), sumos, } \\
\text { tinturas, garrafadas, pomadas e } \\
\text { óleos }\end{array}$ \\
\hline Erva-doce & 5 & Pinpinella anisum $L$. & FB A & $\begin{array}{l}\text { Digestivo, pirose, antidispéptico, } \\
\text { antiespasmódico, antiflatulência, calmante, } \\
\text { expectorante, anti-inflamatório, regulação do fluxo } \\
\text { intestinal, triglicerídeos, cólicas e alergia }\end{array}$ & $\begin{array}{l}\text { Chá, suco, fruta, xarope, pomada, } \\
\text { compressas, gargarejo, garrafadas e } \\
\text { banhos de assento }\end{array}$ \\
\hline
\end{tabular}




\begin{tabular}{|c|c|c|c|c|c|}
\hline Erva-doce & 9 & $\begin{array}{l}\text { Foeniculum vulgare } \\
\text { Mill }\end{array}$ & RS, FB A e B & $\begin{array}{l}\text { Antiespasmódico, carminativo, diurético, anti- } \\
\text { inflamatório, expectorante, bronquite, gripe, tosse, } \\
\text { resfriados, dispepsia, tranquilizante e cólicas em } \\
\text { bebês }\end{array}$ & $\begin{array}{l}\text { Xarope, ervas maceradas e mistas, } \\
\text { infusão (folhas frescas), decocção } \\
\text { (folhas secas, raízes e sementes), } \\
\text { sumos, tinturas, garrafadas, } \\
\text { pomadas e óleos }\end{array}$ \\
\hline Erva cidreira, melissa & 8 & Melissa officinalis & FB A e B & $\begin{array}{l}\text { Reduz a duração e a intensidade dos surtos de } \\
\text { herpes devido a propriedades antivirais, calmante, } \\
\text { insônia, antiespasmódico, } \\
\text { digestivo, gripe e resfriado }\end{array}$ & $\begin{array}{l}\text { Infusão, decocção, comprimido ou } \\
\text { cápsula, xarope, maceração, tintura, } \\
\text { suco in natura fruta, pomada, } \\
\text { compressas, gargarejo, garrafadas e } \\
\text { banhos de assento }\end{array}$ \\
\hline Eucalipto & 1 & $\begin{array}{l}\text { Eucaliptus globulus } \\
\text { Labill. }\end{array}$ & RS e FB B & - & Decocção \\
\hline Erva de São João & 1 & Hypericum perforatum & FB B & Anti- diabética & Folha \\
\hline $\begin{array}{l}\text { Flor e folha de laranjeira, } \\
\text { flor de laranja lima, } \\
\text { laranjeira e laranja }\end{array}$ & 6 & $\begin{array}{l}\text { Citrus sinensis (L.) } \\
\text { Osbeck. } \\
\text { Citrus L. (Rutaceae) }\end{array}$ & - & $\begin{array}{l}\text { Calmante, ansiolítico, sedativo leve, febrífugo, } \\
\text { digestivo, gripe, resfriado e tosse }\end{array}$ & $\begin{array}{l}\text { Infusão, decocção, maceração, suco, } \\
\text { fruta, xarope, pomada, compressa, } \\
\text { gargarejo, garrafada e banho de } \\
\text { assento }\end{array}$ \\
\hline Goiaba, flor de goiaba & 2 & Psidium guajava & RS & Problemas digestivos e diarreia & Decocção \\
\hline Gingko biloba & 2 & Gingko biloba L. & MT & Calmante e ansiedade & - \\
\hline Guaco & 12 & $\begin{array}{l}\text { Mikania glomerata } \\
\text { Spreng }\end{array}$ & $\begin{array}{l}\text { RS, FB A e B, } \\
\text { RE }\end{array}$ & $\begin{array}{l}\text { Broncodilador, expectorante, tosse, catarro, } \\
\text { resfriado, gripe, prevenção e tratamento da asma e } \\
\text { antisséptico das vias respiratórias }\end{array}$ & $\begin{array}{l}\text { Infusão, decocção, maceração, } \\
\text { comprimido, cápsula, xarope, } \\
\text { tintura e suco in natura }\end{array}$ \\
\hline Gengibre & 2 & $\begin{array}{l}\text { Zingiber officinalis } \\
\text { (Willd.) Roscoe }\end{array}$ & $\begin{array}{l}\text { RS, FB A e B, } \\
\text { MT }\end{array}$ & Gripe, resfriado, calmante e digestivo & Infusão, decocção e maceração \\
\hline Garra-do-Diabo & 1 & $\begin{array}{l}\text { Harpagophytum } \\
\text { procumbens DC }\end{array}$ & $\begin{array}{l}\text { RS, FB B, } \\
\text { MT, RE }\end{array}$ & - & Cápsula e comprimido \\
\hline Hortelã & 15 & $\begin{array}{l}\text { Mentha spp* }(\text { M. } \\
\text { crispa, M. piperita ou } \\
\text { M. villosa })\end{array}$ & $\begin{array}{l}\text { RS, FB A e B, } \\
\text { RE }\end{array}$ & $\begin{array}{l}\text { Expectorante, gripe, resfriado, cardiotônico, } \\
\text { hipertensão, derrame, vermífugo, digestivo, } \\
\text { espasmos intestinais, carminativo, antiflatulento, } \\
\text { antiespasmódico, cólica, náuseas, diarreia, } \\
\text { distúrbio hepático, antisséptico, calmante, dor }\end{array}$ & $\begin{array}{l}\text { Infusão, decocção, maceração, } \\
\text { comprimido ou cápsula, xarope e } \\
\text { tintura }\end{array}$ \\
\hline
\end{tabular}




\begin{tabular}{|c|c|c|c|c|c|}
\hline & & & & $\begin{array}{l}\text { (muscular, cabeça, garganta e dente). Atividade } \\
\text { colerética, anti-inflamatória e antiúlcera. }\end{array}$ & \\
\hline Ipê-roxo & 1 & $\begin{array}{l}\text { Handroanthus } \\
\text { impetiginosus }\end{array}$ & RS, FB B & Câncer & Decocção \\
\hline Isoflavona, soja & 2 & $\begin{array}{l}\text { Glycine } \max (\text { L.) } \\
\text { Merr.) }\end{array}$ & $\begin{array}{l}\text { RS, FB B, } \\
\text { MT, RE }\end{array}$ & $\begin{array}{l}\text { Amenizam os sintomas vasomotores decorrentes } \\
\text { do climatério }\end{array}$ & - \\
\hline $\begin{array}{l}\text { Losna, sintro, absinto- } \\
\text { comum, absinto-grande, } \\
\text { absinto-maior, alosna, } \\
\text { artemísia, erva-santa e } \\
\text { artemísia-absinto }\end{array}$ & 3 & $\begin{array}{c}\text { Artemisea absinthium } \\
\text { L. }\end{array}$ & RS & Dor de estômago e dispepsia & Infusão, decocção e maceração \\
\hline Mentruz & 2 & $\begin{array}{l}\text { Coronopus didymus } \\
\text { (L.) Sm, }\end{array}$ & - & Infecção respiratória, expectorante e bronquite & Infusão, decocção e maceração \\
\hline Mentruz & 1 & Lepidium Sativum L. & - & Feridas, luxações e vermífugo & Suco e compressa \\
\hline $\begin{array}{l}\text { Macela, marcela } \mathrm{e} \\
\text { marcelinha }\end{array}$ & 9 & $\begin{array}{c}\text { Achyrocline } \\
\text { satureioides (Lam.) } \\
\text { DC.) }\end{array}$ & FB A e B & 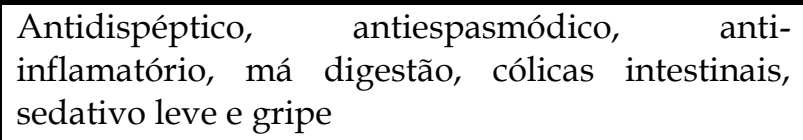 & $\begin{array}{l}\text { Infusão, decocção, maceração; para } \\
\text { tomar e lavar a ferida }\end{array}$ \\
\hline Malva & 6 & Malva sylvestris $L$. & RS, FB A & $\begin{array}{l}\text { Uso interno: expectorante. } \\
\text { Uso externo: anti-inflamatório, antisséptico da } \\
\text { cavidade oral, expectorante, contusões, processos } \\
\text { inflamatórios da boca e da garganta, banho de } \\
\text { assento para aliviar os sintomas da vaginose, } \\
\text { gargarejos para infeçãa na garganta, infeç̧ão na } \\
\text { bexiga, gripe e laxativo }\end{array}$ & $\begin{array}{l}\text { Lavar a ferida, chá (infusão e } \\
\text { maceração), suco, xarope, pomada, } \\
\text { compressas, gargarejo, garrafadas e } \\
\text { banho de assento }\end{array}$ \\
\hline Maracujá & 4 & $\begin{array}{l}\text { Passiflora spp* }(P . \\
\text { alata, P. edulis ou } P \text {. } \\
\text { incarnata })\end{array}$ & $\begin{array}{l}\text { RS, FB A e B, } \\
\text { MT }\end{array}$ & Ansiedade, insônia e calmante & Suco do fruto \\
\hline Poejo & 6 & Mentha pulegium L & RS & $\begin{array}{l}\text { Expectorante, gripe, estimulador de apetite, } \\
\text { perturbações digestivas, } \\
\text { gastrointestinais, cálculos biliares, colecistite, } \\
\text { antioxidante, antihiperglicêmico, } \\
\text { inflamatório, antimicrobiano e vermífugo }\end{array}$ & $\begin{array}{l}\text { Infusão, maceração, decocção, suco } \\
\text { e compressa }\end{array}$ \\
\hline
\end{tabular}




\begin{tabular}{|c|c|c|c|c|c|}
\hline Pata-de-vaca & 3 & Bahuinia sp & RS & Tratamento do diabetes & $\begin{array}{l}\text { Decocção, infusão, maceração e } \\
\text { tintura }\end{array}$ \\
\hline Picão, picão preto & 2 & Bidens pilosa & RS & $\begin{array}{l}\text { Icterícia, coloração amarelada da pele e das } \\
\text { mucosas devido a acumulação de bilirrubina no } \\
\text { organismo }\end{array}$ & Tomar e lavar a ferida; chá \\
\hline Pitanga, folha de pitanga & 3 & Eugenia uniflora & RS & Diarreia, antidiabética e dor no estômago & Infusão, decocção e maceração \\
\hline Quebra-pedra & 3 & $\begin{array}{l}\text { Phyllanthus spp* }(P \text {. } \\
\text { amarus, P.niruri, } P \text {. } \\
\text { tenellus e P. urinaria) }\end{array}$ & RS & Infecção urinária, cálculo renal, cistite e litolítico & $\begin{array}{l}\text { Infusão, decocção, maceração, } \\
\text { sumo, tintura, garrafada, pomada e } \\
\text { óleo }\end{array}$ \\
\hline Romã & 5 & Punica granatum $\mathrm{L}$. & RS, FB A e B & $\begin{array}{l}\text { Faringite, anti-inflamatório gengival, diarreia } \\
\text { (casca) e vermífugo }\end{array}$ & $\begin{array}{l}\text { Infusão, decocção, maceração, } \\
\text { sumo, tintura, garrafada, pomada e } \\
\text { óleo }\end{array}$ \\
\hline Sene & 1 & $\begin{array}{l}\text { Senna occidentalis (L.) } \\
\text { Link) }\end{array}$ & - & Purgativo e laxativo & Infusão, decocção e maceração \\
\hline Sene & 2 & Senna alexandrina & MT & - & Decocção \\
\hline Sene & 1 & Cassia angustifolia & - & Laxativo & Decocção \\
\hline Sabugueiro & 1 & Sambucus nigra & FB A e B & Sarampo & Decocção \\
\hline Salgueiro, Salgueiro-branco & 1 & Salix alba L. & $\begin{array}{l}\text { RS, FB A e B, } \\
\text { RE }\end{array}$ & - & Comprimido, elixir e solução oral \\
\hline Salsa & 1 & $\begin{array}{l}\text { Petroselinum crispum } \\
\text { (Mill.) }\end{array}$ & RS & $\begin{array}{l}\text { Doenças do aparelho circulatório, digestivo, } \\
\text { geniturinário, endócrinas, nutricionais e } \\
\text { metabólicas }\end{array}$ & Chá \\
\hline $\begin{array}{l}\text { Tanchagem, tansagem, } \\
\text { tranchagem }\end{array}$ & 5 & Plantago major & RS, FB A e B & $\begin{array}{l}\text { Chá da semente: laxativo e depurativo; Chá das } \\
\text { folhas: amidalite, faringite, traqueíte, estomatite; } \\
\text { anti-inflamatório e antisséptico da cavidade oral; } \\
\text { Medida de conforto para aliviar os sintomas da } \\
\text { vaginose }\end{array}$ & $\begin{array}{l}\text { Infusão, decocção, maceração, } \\
\text { sumo, tintura, garrafada, pomada, } \\
\text { óleo; Tomar e lavar a ferida e banho } \\
\text { de assento }\end{array}$ \\
\hline $\begin{array}{l}\text { Unha de gato, espera-aí e } \\
\text { junpindá }\end{array}$ & 1 & $\begin{array}{l}\text { Uncaria tomentosa } \\
\text { (Willd. ex Roem. \& } \\
\text { Schult.) }\end{array}$ & $\begin{array}{l}\text { RS, FB B, } \\
\text { MT, RE }\end{array}$ & - & Cápsula, comprimido e gel. \\
\hline
\end{tabular}




\begin{tabular}{|c|c|c|c|c|c|}
\hline Valeriana & 1 & Valeriana officinalis L. & FB B, MT & - & - \\
\hline TOTAL & 251 & & & & \\
\hline
\end{tabular}

Fonte: Elaboração das autoras.

Legendas:

RS: Renisus (BRASIL, 2009)

FB A: Farmacopeia Brasileira (AGÊNCIA NACIONAL DE VIGILÂNCIA SANITÁRIA, 2011); FB B: Farmacopeia Brasileira (AGÊNCIA NACIONAL DE

VIGILÂNCIA SANITÁRIA, 2018); MT: Memento Terepêutico (AGÊNCIA NACIONAL DE VIGILÂNCIA SANITÁRIA, 2016) e RE: Rename (BRASIL, 2018). 


\section{Discussão}

Dentre os 32 estudos analisados na pesquisa, de modo geral, procuraram investigar o uso, o conhecimento, a indicação, a formação acadêmica, a percepção, a representação e a qualificação dos profissionais sobre a temática.

Estudo realizado no Programa de Saúde da Família (PSF) do município de Canoas, Rio Grande do Sul, com 27 médicos teve como objetivo conhecer as representações e a utilização da fitoterapia por parte desta categoria e os fatores relacionados à intenção de uso dessa terapia. Resultados revelaram que 70,4\% prescrevem a seus pacientes e as plantas medicinais mais utilizadas foram a camomila $(33,3 \%)$ e a gingko biloba $(18,5 \%)$, que devido aos efeitos calmantes são alternativas no tratamento dos sintomas da ansiedade, em contraposição ao uso de fármacos benzodiazepínicos (ROSA; CÂMARA; BÉRIA, 2011).

Corroborando com os achados de Rosa; Câmara e Béria (2011), foi realizado estudo na Estratégia Saúde da Família (ESF) de Caicó, Rio Grande do Norte, com 9 médicos, que investigou, o conhecimento e o emprego de fitoterápicos pela classe médica. Sobre o conhecimento de fitoterápicos, $77,7 \%$ dos entrevistados referiram conhecer algum tipo, com destaque para os de propriedade ansiolítica, sedativa e problemas ginecológicos. No entanto, quando questionados sobre orientar o uso de fitoterápicos em sua prática profissional na ESF, alguns profissionais relatam não ter formação técnica para prescrever, por não terem cursado disciplinas na graduação (VARELA; AZEVEDO, 2014).

Pesquisa de Machado; Czermainski e Lopes (2012), realizada com gestores de Unidade Básica de Saúde (UBS), na cidade de Porto Alegre, incluiu 9 enfermeiros, 4 médicos, 1 nutricionista e 1 profissional de outra área de graduação não especificada. A pesquisa procurou conhecer o interesse dos profissionais sobre a inclusão de fitoterápicos na assistência. Os profissionais revelaram ter interesse na incorporação de terapias complementares ou integrativas à rede de Atenção Primária à Saúde (APS) do seu município, principalmente para fitoterapia, acupuntura e homeopatia. Sobre o nível de conhecimento sobre terapias complementares e integrativas a maioria mostrou possuir conhecimento básico, o que alerta para a necessidade de futuras capacitações sobre o tema. 
Quando questionados sobre a indicação e prescrição de plantas medicinais e fitoterápicos pelos profissionais prescritores desta UBS, há a percepção de que os prescritores recomendam mais plantas medicinais do que fitoterápicos (MACHADO; CZERMAINSKI; LOPES, 2012)

O trabalho de Bruning; Mosegui e Vianna (2012), que analisou o conhecimento sobre fitoterapia entre 10 profissionais de saúde (5 enfermeiros, 3 médicos, 1 auxiliar de enfermagem e 1 técnica em enfermagem), revelou que apenas médicos e enfermeiros eram treinados a prescrever plantas medicinais e habilitadas à prescrição de fitoterápicos, sendo que os demais profissionais sugerem o uso desses elementos de forma caseira através do conhecimento popular.

Uma análise feita pela ESF no interior de Petrolina, Pernambuco, que contou com a participação de 96 profissionais (entre médicos, enfermeiros, cirurgiões dentistas, farmacêuticos e nutricionistas) verificou a importância, utilização e indicações de plantas medicinais e fitoterápicos. A maioria dos profissionais entrevistados (99\%) manifestaram-se a favor da importância sobre o conhecimento e a indicação de fitoterápicos, porém alguns $(66,7 \%)$ não sabiam diferenciar corretamente fitoterápicos e homeopáticos, indicando a necessidade de capacitação desses profissionais quanto ao uso dessa terapêutica. Sobre a prescrição de fitoterápicos nesta ESF 36,5\% do total de profissionais costumam prescrever, sendo a classe médica a grande maioria dos prescritores, porém sem formação em fitoterapia (NASCIMENTO JÚNIOR et al., 2016).

Quando questionados sobre a correta orientação aos pacientes acerca a forma de utilização de plantas medicinais, 62,5\% afirmaram desconhecer como fazêlos (NASCIMENTO JÚNIOR et al., 2016).

Em relação às plantas medicinais mais citadas pelos profissionais foram: camomila (Matricaria recutita L); boldo (Peumus boldus M.) e os fitoterápicos Guaco® (Mikania glomerata S.); Maracugina ${ }^{\circledR}$ (Passiflora alata A., Erythrina mulungu M. e Crataegus oxyacantha L.) (NASCIMENTO JÚNIOR et al., 2016).

Uma outra pesquisa desenvolvida com 66 equipes de ESF do município de Blumenau, Santa Catarina incluindo a participação médicos, enfermeiros, técnicos de enfermagem, odontólogos e técnicos de saúde bucal, exibiu que 96,2\% dos pro- 
fissionais acreditam no efeito terapêutico das plantas medicinais, mas não as prescrevem regularmente. Quando questionados sobre a utilização pessoal de plantas medicinais ou de fitoterápicos, 89,1\% manifestaram-se positivamente e 84,7\% afirmaram prescrever e/ou sugerir em algum momento aos pacientes. O termo "sugeriu" aqui se aplica uma vez que os técnicos de enfermagem e de saúde bucal não podem prescrever medicamentos, por estarem impedidos pela legislação vigente. $\mathrm{Na}$ ocasião que os profissionais são questionados sobre recomendar alguma planta medicinal junto com uma medicação prescrita, encontrou-se que 68,8\% aprovam a utilização conjunta, embora $17,2 \%$ responderam que não interfeririam o uso e os outros $8,3 \%$ se posicionariam contrários, enquanto $5,7 \%$ responderam que dependeria da situação, especialmente do conhecimento que o profissional tivesse a respeito da planta referida pelo paciente e da gravidade do quadro clínico. Ao ser investigado se a fitoterapia é utilizada no cotidiano da ESF, 70,7\% dos profissionais relataram que a população demonstra interesse nesta prática (MATTOS et al., 2018).

Nesta pesquisa, 98,7\% dos profissionais concordam com a iniciativa de ofertar esta prática integrativa e complementar no SUS, porém defendem que essa prática seja instaurada após uma capacitação na área e que possuem interesse em receber informações sobre a utilização de plantas medicinais na APS através de cursos ou capacitações $(71,4 \%)$, literatura impressa $(20,1 \%)$, palestras $(5,8 \%)$ e videoaulas (2,6\%) (MATTOS et al., 2018).

Apesar das indicações, os profissionais relataram a falta de estudos clínicos comprovando eficácia, indicações, validade de uso, dosagem e contraindicações dos medicamentos fitoterápicos, além de consideram falha a divulgação dos estudos com fitoterápicos entre a classe médica, realidade que dificulta a inserção da fitoterapia como rotina no atendimento à população (ROSA; CÂMARA; BÉRIA, 2011).

O estudo apresentou como limitações apenas dois estudos com profissionais nutricionistas e a não inclusão de artigos com gestantes, mulheres, usuários do SUS, idosos e estudos com patologias na discussão. 


\section{Conclusão}

Os profissionais mais presentes nos estudos são médicos e enfermeiros, as plantas medicinais mais utilizadas são boldo, camomila, hortelã e capim-santo e os fitoterápicos são o guaco e a soja e seus modos de uso infusão, decocção, maceração e xarope. Devido ao contexto histórico das plantas medicinais e da fitoterapia, houve a necessidade de regulamentar profissionais de saúde que possam prescrevê-los para garantir o acesso e a integralidade da assistência, bem como o uso seguro e racional para os usuários. No entanto, é necessário que a fitoterapia, assim como as outras práticas integrativas mantenham uma política de financiamento para o desenvolvimento de suas ações práticas, além do incentivo a qualificação dos profissionais de saúde para que possam oferecer um serviço resolutivo à população. 


\section{Referências}

AGÊNCIA NACIONAL DE VIGILÂNCIA SANITÁRIA (Brasil). Formulário de fitoterápicos da farmacopeia brasileira. Brasília, DF: Agência Nacional de Vigilância Sanitária, 2011. Disponível em:

http://portal.anvisa.gov.br/documents/33832/259456/Formulario_de_Fitoterapico s_da_Farmacopeia_Brasileira.pdf/c76283eb-29f6-4b15-8755-2073e5b4c5bf. Acesso em: 3 set. 2021.

AGÊNCIA NACIONAL DE VIGILÂNCIA SANITÁRIA (Brasil). Memento fitoterápico: farmacopeia brasileira. Brasília, DF: Agência Nacional de Vigilância Sanitária, 2016. Disponível em:

http://www.farmacia.pe.gov.br/sites/farmacia.saude.pe.gov.br/files/memento_fit oterapico.pdf. Acesso em: 3 set. 2021.

ARAÚJO, Cristina Ruan Ferreira de et al. Efeitos teratogênicos e abortivos por gestantes em uma cidade no Nordeste do Brasil. Revista Brasileira de Ginecologia e Obstetrícia, Rio de Janeiro, v. 38, n. 3, p. 127-131, mar. 2016. Disponível em:

http:// www.scielo.br/scielo.php?script=sci_arttext\&pid=S0100-

72032016000300127\&lng=en\&nrm=iso\&tlng=en. Acesso em: 18 abr. 2020.

BADKE, Marcio Rossato et al. Plantas medicinais: o saber sustentado na prática do cotidiano popular. Escola Anna Nery Revista de Enfermagem, v. 15, n. 1, p. 132-139, 2011. Disponível em: http://www.scielo.br/pdf/ean/v15n1/19.pdf. Acesso em: 14 mar. 2020.

BRASIL. Decreto $n^{\circ} 5.813$, de 22 de junho de 2006. Aprova a Política Nacional de Plantas Medicinais e Fitoterápicos e dá outras providências. Diário Oficial [da] República Federativa do Brasil: seção 1, Brasília, DF, 23 jun. 2006. Disponível em: http://www.planalto.gov.br/ccivil_03/_ato2004-2006/2006/decreto/d5813.htm. Acesso em: 3 set. 2021.

BRASIL. Ministério da Saúde. Relação Nacional de Plantas Medicinais de Interesse do SUS - RENISUS. Brasília, DF: Ministério da Saúde, 2009. Disponível em: https://bvsms.saude.gov.br/bvs/sus/pdf/marco/ms_relacao_plantas_medicinais_s us_0603.pdf. Acesso em: 3 set. 2021.

BRASIL. Ministério da Saúde. Secretaria de Ciência, Tecnologia e Insumos Estratégicos. Relação Nacional de Medicamentos Essenciais: RENAME 2018. Brasília, DF: Ministério da Saúde, 2018. 218 p. 
BRASIL. Resolução n ${ }^{\circ}$ 680, de 19 de janeiro de 2021. Regulamenta a prática da fitoterapia pelo nutricionista e dá outras providências. Diário Oficial [da] República Federativa do Brasil: seção 1, Brasília, DF, n. 13, p. 78-79, 20 jan. 2021. Disponível em: https://www.cfn.org.br/wp-content/uploads/resolucoes/Res_680_2021.html. Acesso em: 28 jul. 2021.

BRUNING, Maria Cecilia Ribeiro; MOSEGUI, Gabriela Bittencourt Gonzalez; VIANNA, Cid Manso de Melo. A utilização da fitoterapia e de plantas medicinais em unidades básicas de saúde nos municípios de Cascavel e Foz do Iguaçu - Paraná: a visão dos profissionais de saúde. Ciência \& Saúde Coletiva, Rio de Janeiro, v. 17, n. 10, p. 2675-2685, 2012. Disponível em: http://www.scielo.br/pdf/csc/v17n10/17.pdf. Acesso em: 14 mar. 2020.

COLET, Christiane de Fátima et al. Uso de plantas medicinais por usuários do serviço público de saúde do município de Ijuí/RS. Revista Brasileira de Medicina da Família e Comunidade, v. 10, n. 36, p. 1-13, 2015. Disponível em: https://rbmfc.org.br/rbmfc/article/view/930. Acesso em: 28 set. 2021.

DEFANI, Marli Aparecida; OLIVEIRA, Luis Eduardo Negrão de. Utilização das plantas medicinais por diabéticos do município de Colorado (PR). Revista Saúde e Pesquisa, Maringá, v. 8, n. 3, p. 413-421, set./dez. 2015. Disponível em: https://periodicos.unicesumar.edu.br/index.php/saudpesq/article/view/4214/268 7. Acesso em: 18 abr. 2020.

FEIJÓ, A. M. et al. Plantas medicinais utilizadas por idosos com diagnóstico de Diabetes mellitus no tratamento dos sintomas da doença. Revista Brasileira de Plantas Medicinais, Botucatu, v. 14, n. 1, p. 50-56, 2012. Disponível em: http:// www.scielo.br/scielo.php?script=sci_arttext\&pid=S151605722012000100008\&lng=en\&nrm=iso\&tlng=pt. Acesso em: 18 abr. 2020.

GRIBNER, Caroline; RATTMANN, Yanna Dantas; GOMES, Eliane Carneiro. Use of industrialized herbal medicines by patients attended at the basic health units in the County of Pinhais, Paraná, Brazil. Blacpma, Chile, v. 17, n. 3, p. 238-248, 2018. Disponível em: https://www.blacpma.usach.cl/sites/blacpma/files/articulo_1__1391___238_-_248.pdf. Acesso em: 18 abr. 2020.

HASENCLEVER, Lia et al. A indústria de fitoterápicos brasileira: desafios e oportunidades. Ciência \& Saúde Coletiva, Rio de Janeiro, v. 22, n. 8, p. 2559-2569, 2017. Disponível em: http://www.scielo.br/pdf/csc/v22n8/1413-8123-csc-22-082559.pdf. Acesso em: 14 mar. 2020

LIMA, Diego Florêncio et al. Conhecimento e uso de plantas medicinais por usuários de duas unidades básicas de saúde. Revista Rene, Fortaleza, v. 15, n. 3, p. 383-390, 2014. Disponível em: http://www.periodicos.ufc.br/rene/article/view/3181/2444. Acesso em: 18 abr. 2020. 
LIMA, Silvia Cristina da Silva et al. Representações e usos de plantas medicinais em homens idosos. Revista Latino-americana de Enfermagem, Ribeirão Preto, v. 20, n. 4, p. 1-8, jul./ago. 2012. Disponível em:

http://www.scielo.br/scielo.php?script=sci_arttext\&pid=S0104-11692012000400019. Acesso em: 18 abr. 2020.

LOPES, M. A. et al. Estudo das plantas medicinais, utilizadas pelos pacientes atendidos no programa "Estratégia Saúde da Família" em Maringá, PR, Brasil.

Revista Brasileira Plantas Medicinais, Botucatu, v. 17, n. 4, p. 702-706, 2015.

Suplemento 1. Disponível em:

http:/ / www.scielo.br/scielo.php?script=sci_arttext\&pid=S1516-

05722015000500702\&lng=en\&nrm=iso\&tlng=pt. Acesso em: 18 abr. 2020.

MACHADO, Dayane Cordeiro; CZERMAINSKI, Silvia Beatriz Costa; LOPES, Edyane Cardoso. Percepções de coordenadores de unidades de saúde sobre a fitoterapia e outras práticas integrativas e complementares. Saúde em Debate, Rio de Janeiro, v. 36, n. 95, p. 615-623, out./dez. 2012. Disponível em:

http://www.scielo.br/pdf/sdeb/v36n95/a13v36n95.pdf. Acesso em: 14 mar. 2020.

MATTOS, Gerson et al. Plantas medicinais e fitoterápicas na atenção primária em saúde: percepção dos profissionais. Ciência \& Saúde Coletiva, Rio de Janeiro, v. 23, n. 11, p. 3735-3744, 2018. Disponível em:

http://www.scielo.br/scielo.php?script=sci_arttext\&pid=S1413-

81232018001103735\&lng=pt\&nrm=iso\&tlng=pt. Acesso em: 18 abr. 2020.

MEGA, Tacila Pires et al. Uso de ervas medicinais por pacientes com asma grave atendidos em um centro de referência. Revista Brasileira de Ciências Farmacêuticas, São Paulo, v. 47, n. 3, p. 644-649, jul./set. 2011. Disponível em:

http://www.scielo.br/scielo.php?script=sci_arttext\&pid=S1984-82502011000300024. Acesso em: 18 abr. 2020.

NASCIMENTO JÚNIOR, B. J. et al. Avaliação do conhecimento e percepção dos profissionais da Estratégia de Saúde da Família sobre o uso de plantas medicinais e fitoterapia em Petrolina-PE, Brasil. Revista Brasileira de Plantas Medicinais, Campinas, v. 18, n. 1, p. 57-66, 2016. Disponível em: http:/ / www.scielo.br/scielo.php?script=sci_arttext\&pid=S151605722016000100057\&lng=en\&nrm=iso\&tlng=pt. Acesso em: 18 abr. 2020.

OLIVEIRA, Gisele Lopes de; OLIVEIRA, Antonio Fernando Morais de; ANDRADE, Laise de Holanda Cavalcanti. Plantas medicinais utilizadas na comunidade urbana de Muribeca, Nordeste do Brasil. Acta Botanica Brasilica, Recife, v. 24, n. 2, p. 571577, 2010. Disponível em: http://www.scielo.br/pdf/abb/v24n2/a26v24n2.pdf. Acesso em: 14 mar. 2020. 
OLIVEIRA, Vinícius Bednarczuk de; MEZZOMO, Thais Regina; MORAES, Eliézer Fernanda de. Conhecimento e uso de plantas medicinais por usuários de unidades básicas de saúde na Região de Colombo, PR. Revista Brasileira de Ciências da Saúde, Curitiba, v. 22, n. 1, p. 57-64, 2018. Disponível em:

https://periodicos.ufpb.br/ojs2/index.php/rbcs/article/view/30038/19491. Acesso em: 18 abr. 2020.

RANGEL, M.; BRAGANÇA, F. C. R. Representações de gestantes sobre o uso de plantas medicinais. Revista Brasileira de Plantas Medicinais, Botucatu, v. 11, n. 1, p. 100-109, 2009. Disponível em:

http:// www.scielo.br/scielo.php?script=sci_arttext\&pid=S1516-05722009000100016. Acesso em: 18 abr. 2020.

ROSA, Caroline da; CÂMARA, Sheila Gonçalves; BÉRIA, Jorge Umberto. Representações e intenção de uso da fitoterapia na atenção básica à saúde. Ciência \& Saúde Coletiva, Rio Grande do Sul, v. 16, n. 1, p. 311-318, 2011. Disponível em: http:// www.scielo.br/pdf/csc/v16n1/v16n1a33.pdf. Acesso em: 14 mar. 2020.

SANTOS, M. M.; NUNES, M. G. S.; MARTINS, R. D. Uso empírico de plantas medicinais para tratamento de diabetes. Revista Brasileira de Plantas Medicinais, Botucatu, v. 14, n. 2, p. 327-334, 2012. Disponível em: http:/ / www.scielo.br/scielo.php?script=sci_arttext\&pid=S151605722012000200012\&lng=en\&nrm=iso\&tlng=pt. Acesso em: 18 abr. 2020.

SCHIAVO, Morgana et al. Conhecimento sobre plantas medicinais por mulheres em processo de envelhecimento. Ciências Biológicas e da Saúde, Londrina, v. 38, n. 1, p. 45-60, jan./jun. 2017. Disponível em:

http:// www.uel.br/revistas/uel/index.php/seminabio/article/view/27279. Acesso em: 18 abr. 2020.

SCHIAVO, Morgana; SCHWAMBACH, Karin Hepp; COLET, Christiane de Fátima. Conhecimento sobre plantas medicinais e fitoterápicos de agentes comunitários de saúde de Ijuí/RS. Revista de Pesquisa Cuidado é Fundamental Online, Rio de Janeiro, v. 9, n. 1, p. 57-63, jan./mar. 2017. Disponível em:

http:// www.seer.unirio.br/cuidadofundamental/article/view/4271/pdf_1. Acesso em: 18 abr. 2020.

SILVA, Dalva Cezar da et al. Utilização de plantas medicinais por pessoas com úlcera venosa em tratamento ambulatorial. Revista de Pesquisa de Cuidado é Fundamental, Rio de Janeiro, v. 7, n. 3, p. 2985-2997, jul./ set. 2015. Disponível em: https://www.redalyc.org/pdf/5057/505750947025.pdf. Acesso em: 18 abr. 2020.

SIQUEIRA, Ana Bolena de Luna; MARTINS, René Duarte. Prescrição fitoterápica por nutricionistas: percepção e adequação à prática. Revista de Ciências da Saúde, Pernambuco, v. 30, n. 1, p. 72-83, 2018. Disponível em:

https://periodicos.furg.br/vittalle/article/view/7744/5309. Acesso em: 6 set. 2019. 
SOUZA, A. D. Z. et al. O processo de trabalho dos enfermeiros da atenção primária e a política nacional de plantas medicinais/fitoterápicos. Revista Brasileira de Plantas Medicinais, Campinas, v. 18, n. 2, p. 480-487, 2016. Disponível em:

http:/ / www.scielo.br/scielo.php?script=sci_arttext\&pid=S1516-

05722016000200480\&lng=en\&nrm=iso\&tlng=pt. Acesso em: 18 abr. 2020.

SOUZA, C. M. P. et al. Utilização de plantas medicinais com atividade antimicrobiana por usuários do serviço público de saúde em Campina Grande - Paraíba. Revista

Brasileira de Plantas Medicinais, Campinas, v. 15, n. 2, p. 188-193, 2013. Disponível em: http://www.scielo.br/scielo.php?script=sci_arttext\&pid=S1516-

05722013000200004. Acesso em: 18 abr. 2020.

SOUZA MARIA, N. C. V. et al. Plantas medicinais abortivas utilizadas por mulheres de UBS: etnofarmacologia e análises cromatográficas por CCD e CLAE. Revista

Brasileira de Plantas Medicinais, Botucatu, v. 15, n. 4, p. 763-773, 2013. Disponível em: http://www.scielo.br/scielo.php?script=sci_arttext\&pid=S151605722013000500018. Acesso em: 18 abr. 2020.

SZERWIESKI, Laura Ligiana Dias et al. Uso de plantas medicinais por idosos da atenção primária. Revista Eletrônica de Enfermagem, Maringá, v. 19, n. 4, p. 1-11, 2017. Disponível em: https://revistas.ufg.br/fen/article/view/42009/22840. Acesso em: 18 abr. 2020.

VALVERDE, Amanda Viegas; SILVA, Nina Cláudia Barboza; ALMEIDA, Mara Zélia. Introdução da fitoterapia no SUS: contribuindo com a Estratégia de Saúde da Família na comunidade rural de Palmares, Paty do Alferes, Rio de Janeiro. Revista Fitos, Rio de Janeiro, v. 12, n. 1, p. 27-40, 2018. Disponível em:

https://www.arca.fiocruz.br/bitstream/icict/26728/2/amanda_viegas_et_all.pdf.

Acesso em: 18 abr. 2020.

VARELA, Danielle Sousa Silva; AZEVEDO, Dulcian Medeiros de. Saberes e práticas fitoterápicas de médicos na estratégia saúde da família. Trabalho, Educação e Saúde, Rio de Janeiro, v. 12, n. 2, p. 273-290, maio/ago. 2014. Disponível em:

http://www.scielo.br/scielo.php?script=sci_arttext\&pid=S1981-

77462014000200004\&lng=pt\&nrm=iso\&tlng=pt. Acesso em: 18 abr. 2020.

VARGAS, Emília Cristina Aguiar et al. Uso de plantas com fins terapêuticos por usuários de uma unidade pré-hospitalar pública de Campos dos Goytacazes, Rio de Janeiro, Brasil. Revista de Pesquisa Cuidado é Fundamental, Rio de Janeiro, v. 11, n. 5, p. 1129-1134, 2019. Disponível em:

https://ciberindex.com/index.php/ps/article/view/P11291134. Acesso em: 18 abr. 2020. 
VIRGÍNIO, Taís Batista et al. Utilização de plantas medicinais por pacientes hipertensos e diabéticos: estudo transversal no nordeste brasileiro. Revista Brasileira em Promoção da Saúde, Fortaleza, v. 31, n. 4, p. 1-10, 2018. Disponível em: https://periodicos.unifor.br/RBPS/article/view/8754. Acesso em: 18 abr. 2020.

ZAMPIROLLI, Ana Caroline Diniz et al. Utilização de medicamentos e plantas medicinais por gestantes atendidas na unidade de saúde da mulher em Alegre, ES, Brasil. Infarma Ciências Farmacêuticas, Brasília, DF, v. 29, n. 4, p. 349-356, 2017. Disponível em:

http://www.revistas.cff.org.br/?journal=infarma\&page=article\&op=view\&path $\% 5 \mathrm{~B}$ \%5D=2078\&path\%5B\%5D=pdf. Acesso em: 18 abr. 2020.

ZENI, Ana Lúcia Bertarello et al. Utilização de plantas medicinais como remédio caseiro na Atenção Primária em Blumenau, Santa Catarina, Brasil. Ciência \& Saúde Coletiva, Rio de Janeiro, v. 22, n. 8, p. 2703-2712, 2017. Disponível em:

http:/ / www.scielo.br/scielo.php?script=sci_arttext\&pid=S1413-

81232017002802703\&lng=en\&nrm=iso\&tlng=pt. Acesso em: 18 abr. 2020. 
10

Análise do discurso de

mulheres em relação a sua

decisão de parirna

perspectiva foucaultiana de

governamentalidade sobre

os corpos 


\title{
10 ANÁLISE DO DISCURSO DE MULHERES EM RELAÇÃO A SUA DECISÃO DE PARIR NA PERSPECTIVA FOUCAULTIANA DE GOVERNAMENTALIDADE SOBRE OS CORPOS
}

\author{
Cadidja Caldas Silva \\ Daniele Vasconcelos Fernandes Vieira \\ Terezinha Almeida Queiroz \\ Francisca Heronildes Patrício Caetano \\ Ana Paula da Silva Morais \\ Marcélid Berto da Costa
}

\section{Resumo}

Introdução: A problemática do parto humanizado e a adesão crescente de mulheres em busca de um parir diferente, principalmente, como forma de resistência à medicalização e a verdade médica sobre o corpo da mulher, suscitou a questionar se essas formas de parto serviriam de controle sobre a saúde da mulher. Objetivo: Analisar o discurso de mulheres em relação a sua decisão de parir, na perspectiva Foucaultiana de governamentalidade sobre os corpos. Método: Realizou-se uma Análise de Discurso com base em Foucault entre a noção de governamentalidade e as problemáticas do parto humanizado descritos no livro "Cenas de parto e políticas do corpo". Resultados: Encontraram-se as seguintes categorias discursivas: ações de governamentalidade sobre as escolhas das mulheres que buscam um parir diferente; e o uso do pensamento de Foucault como ferramenta para problematizar os discursos que se apresentam com caráter universal e os seus efeitos. Conclusão: Considera-se que as resistências foram capturadas servindo de controle sobre a vida das mulheres. Além de controle, servindo também como forma de lucratividade. Os ideais que constroem a própria subjetividade e que permitem fazer escolhas, ou seja, a escolha de um parto menos invasivo e pessoal, ensejam maneiras de poder, de governo.

Palavras-chave: Governamentalidade. Parto Humanizado. Parir Diferente. Análise do Discurso. 


\section{Introdução}

As liberdades sempre serão objetos de disputas, lutas, resistências, tensão e com as mulheres, como não poderia ser diferente de nenhuma outra luta, é acompanhada de um longo processo histórico-social-cultural de construção.

Como expôs Wollstonecraft (2016), as mulheres muito têm lutado por suas liberdades e, como tema de interesse desse artigo, permanece, mesmo em tempos modernos e de liberação dos tabus, a questão sobre decidir o que fazer com seu próprio corpo.

Ao tratarmos desta questão, trazemos em alto relevo as reivindicações por autonomia corporal, controle de fecundidade e atenção à saúde reprodutiva. Tomando como base Wollstonecraft (2016), essas lutas pela gestão do seu próprio corpo, são datadas desde o Século XVIII, o que pode ser verificado na obra "Reivindicação dos Direitos da Mulher", um manifesto realizado pela feminista Mary Wollstonecraft, em torno de 1792. Segundo a autora que aponta este exemplo, o manifesto tem como objetivo a busca de igualdade, apesar de muitas historiadoras já sinalizarem lutas anteriores a esse período.

No que se refere ao controle de natalidade, taxa de fecundidade, crescimento demográfico e outras formas de controle de responsabilidade do Estado, essas lutas das mulheres perpassam até os dias atuais, tendo como destaque as décadas de 1950 e 1960, nas quais, de acordo com Ventura (2009), houve um aumento do crescimento demográfico, despertando a atenção do Estado que procurou adotar medidas e Políticas com fins de redução da fecundidade, o que provocou essa discussão em várias conferências internacionais sobre população e desenvolvimento realizada pela Organização das Nações Unidas (ONU), das quais chegaram ao conceito de direito e saúde reprodutiva (VENTURA, 2009).

Com base nessa preocupação, o parto humanizado surge no Brasil na década de 1990 como resultado entre as críticas ao sistema médico obstétrico vigente e as novas propostas de atenção ao nascimento. Criticavam as altas taxas de cesáreas, os descumprimentos das recomendações da Organização Mundial de Saúde (OMS), sobre a assistência do parto, puerpério e saúde materno-infantil. Em 1993, insatisfeitos 
com tais práticas médicas surge a Rede de Humanização do Nascimento (ReHuNa) que além de criticar tais procedimentos que tornaram práticas padronizadas e invasivas, buscam divulgar a assistência e cuidados perinatais com bases em evidências científicas (CARNEIRO, 2015).

Tal entendimento permite questionar sobre uma determinada população, as mulheres, e suas relações com um certo tipo de direito e um certo tipo de saúde, o direito reprodutivo e a saúde da mulher no que comportam certas formas de normalização, ou seja, se configuram como o resultado do governo da vida das mulheres.

As normas que se faz referência neste artigo não são restritas ao seu sentido binário, normal ou anormal, legal ou ilegal, mas no sentido que privilegia as práticas, em que a forma da lei e a normalização se implica mutuamente gerando modos de agenciamentos dos mecanismos de normalização, os quais Foucault (2008) no curso "Segurança, território e população" chamará de poder. O biopoder são mecanismos que atuam sobre a espécie humana naquilo que constitui suas características biológicas fundamentais, portanto, atuará sobre o corpo que gera, ou seja, o único corpo (espécie, as mulheres) capaz de gerar uma vida, lançando sobre ele mecanismos de estratégias políticas como estratégias de poder.

No Brasil, devido aos problemas ocasionados pela prática de violência obstetras, dos inúmeros casos de cesáreas tornou-se problema de saúde pública, e ainda por constituir violação ao direito à vida, à liberdade e a saúde da mulher, por violar direitos fundamentais tornou-se, também, questões de direitos humanos. Tais problemas e violações instiga a pensar uma Saúde, principalmente em relação a uma arte de governar o domínio da vida de certa população, as mulheres.

Diante dos questionamentos, a presente pesquisa levanta como problema, como pensar o parto humanizado natural como condições para uma governamentalidade do Eu do que uma simples resistência a um parto hospitalar e médico? Para responder tais questionamentos a pesquisa levanta como objetivo geral analisar a noção de governo em relação ao parto humanizado. Em busca de atingir tal perspectiva tem como objetivo específico orientar as noções de governamentalidade 
sob a ótica do pensamento de Michel Foucault; e observar o investimento de normalização sobre as mulheres.

Tal pesquisa tem como interesse as questões feministas, no sentido de problematizar o modo como as mulheres são alvo de uma economia que se utiliza de suas conquistas para exercer uma forma de controle.

Portanto, a pesquisa constrói o objeto a partir do conhecimento dessas estratégias e táticas de controle, como uma rede de poder que se está em evidência e torna-se visível e dizível, de modo que possibilite transformações, mudanças de um presente totalmente construído e possível de constituições.

\section{Objetivo}

Analisar o discurso de mulheres em relação a sua decisão de parir, na perspectiva foucaultiana de governamentalidade sobre os corpos.

\section{Método}

Pesquisa do tipo Análise do Discurso, segundo a perspectiva de Michel Foucault, por meio da qual foi construído um percurso metodológico permeado pelas questões do poder, da relação do poder com determinados discursos e os efeitos de verdades que potencialmente possibilitam a análise do discurso como uma ferramenta metodológica (FOUCAULT, 2010).

$\mathrm{Na}$ análise de discurso Foucault propõe entender os discursos como um bem que tem suas regras de aparecimento, tem suas condições de apropriação e de utilização; é um bem que coloca desde sua existência uma questão do poder; um bem que é objeto de uma luta, e uma luta política (FOUCAULT, 2010). Os discursos que circulam ou são interditados encontram no poder suas condições de existência, ou seja, se trata da uma formação de uma complexa rede de relações na sociedade que permitem que outros discursos surjam, se combinem ou produzam um contexto novo. Os discursos se organizam e se propagam através de suas regras internas e externas. Nesse trabalho daremos preferência as regras externas, à materialidade do discurso 
que produzem efeitos de verdade, são dados constituídos por fragmentos que podem ser analisados por seus traços e formas exteriores, em sua positividade, em sua forma contemporânea (FERREIRA; TRAVERSINI, 2013).

Na Ordem do Discurso, Foucault (2010) aponta procedimentos que são exercidos no exterior e no interior dos discursos. Ao que se refere procedimento exercido no exterior, são aqueles procedimentos de exclusão que operam de três modos: pela interdição que consiste no controle do que pode ser dito, em que circunstância e a quem é permitido falar; o segundo modo é pela separação e rejeição, é pela palavra que identifica o objeto, aquilo que antes era ignorado é tomado por uma representação excepcional de uma razão e separada das considerações ajuizadas. Foucault representa na condição da loucura, a fala do louco antes era ignorada e depois passa ser ouvida e validada pelos especialistas da loucura: psiquiatras, psicólogos, pedagogos, fazendo uma separação do discurso da razão e do discurso ajuizado. E o terceiro procedimento de exclusão é a vontade de verdade, caracterizada pela vontade de definir as formas, os domínios dos objetos e as técnicas de apoio, as quais confere aos discursos o status de verdade por determinados períodos (FERREIRA; TRAVERSINI, 2013).

Assim, alicerçando-se no conceito de discurso de Foucault, serão problematizados e analisados os relatos de um grupo de mulheres que escolheu o que a autora Carneiro (2015) denomina de "parir diferente", isto pode ser dito como "parir da forma mais natural possível". A partir disso, selecionaram-se mulheres que já pariram e, novamente, grávidas afirmavam que não esperavam repetir as experiências anteriores que consideraram dolorosas. A autora ouviu também gestantes primíparas, aquelas que estão na sua primeira gestação. Com estas gestantes, ela recortou seus interesses em encontrar novas possibilidades de parir e decidir qual a melhor para si. A obra "Cenas de Partos e Políticas do Corpo" da autora Rosamaria Giatti Carneiro (CARNEIRO, 2015) é produto de uma pesquisa etnográfica na área da saúde e faz relação com o tema sobre "Saúde Sexual e Reprodutiva".

Na referida obra, a problemática dos partos cesáreos no Brasil mostra que o país é o recordista mundial dessas cirurgias, tanto na rede pública quanto na rede privada. A autora traz, como preocupação, além do alto número de cesarianas, os 
motivos escondidos ou ocultos na escolha desse tipo de parto, ou seja, quem escolhe e por que escolhe, que sustenta os discursos da govenamentalidade neoliberal, como verdades do parto ideal na contemporaneidade.

Para melhor compreender sobre as conexões entre poder, discurso e verdade presentes na obra, foram priorizados os procedimentos externos das categorias de análise de discursos foucaultianos que compreende os mecanismos de interdição, separação e rejeição, e vontade de verdade. Tais mecanismos permite visibilizar nos discursos das mulheres, entre outros pontos, o que existe de um lado, dentro de um espaço, os que controlam a palavra e do outro lado os que almejam falar, instaurando um jogo entre o direito e o poder de algo dizer (SILVA, 2020). Dentro do sistema de exclusão os sujeitos, ou seja, as mulheres, são controladas ao participarem da produção e circulação dos discursos.

Quanto à interdição da palavra, esta acontece quando o sujeito não tem o direito de dizer tudo, não pode falar de tudo em qualquer circunstância, não é qualquer pessoa que pode falar de qualquer coisa. Foucault (2010) demonstra três tipos de interdição dos discursos: o tabu do objeto, o ritual das circunstâncias e o direito exclusivo de quem fala. Entre os dois grupos de mulheres foram selecionados o que se falava, era relatada as experiências individuais a partir do desejo de ter um parto diferente, um parir próprio seu (tabu do objeto). Elas escancaravam naquele determinado espaço, o grupo, suas experiências de uma parição frustrada ou negada a si o direito de como decidir ou manejar a vinda dos filhos (ritual das circunstâncias); suas falas, seus desejos expressos eram legitimados por profissionais da saúde que ali frequentavam, que eram sujeitos autorizados a falarem de determinados temas (direito exclusivo de quem fala).

$\mathrm{Na}$ outra forma de exclusão, em separação e rejeição da palavra, compreende o procedimento que designa as formas de seleção de discursos e sujeitos (FOUCAULT, 2010). Vamos no valer da palavra das mulheres, que em dado momento, é retirado do âmbito social, por não está conectada a um saber especialista, a uma razão, ou seja, um discurso de senso comum, e são separadas de um saber que segue uma lógica científica, por ser consideradas uma fonte segura e logo tidos como verdade. O último procedimento a vontade de verdade se liga em práticas de exclusão 
através de avaliações que têm respaldo das instituições e se constitui em uma rede de saberes que visam dá o caráter de verdade a um discurso (SILVA, 2020).

Dentro dos procedimentos de exclusão existe o conceito de poder como um jogo de relações de saberes, não existe saber sem poder e entende-se o poder como uma prática social, constituída historicamente. Em seus estudos Foucault, também, observou outras formas de exercício de poder, encontrando uma assimetria entre Estado e poder. Ele observou que esse poder operava na realidade mais concreta dos indivíduos, em seu próprio corpo, constituindo um corpo social. Os discursos de poder não foram criados pelo Estado, mas nasciam em seu interior e a ele se submetiam (FOUCAULT, 2017). Por isso, as pesquisas foucaultianas partem de pontos específicos de saberes, aqui no caso, um parir diferente das mulheres, para observar como os poderes se relacionam com os níveis de poder constituído pelo Estado (SILVA, 2020).

Nesse ínterim, o discurso neoliberal busca apoio, sustentação, nos lugares e saberes que operam no interior de regimes de verdade. Se apresenta de forma sedutora e atrativa, se colocando como inquestionável nas articulações entre afeto e ciência (FERREIRA; TRAVERSINI, 2013). Na última etapa de análise, serão evidenciadas as relações de poder possibilitadoras dos discursos que criam subjetividades maternas nessas mulheres e as submissões das mesmas a essas subjetividades por meio do conceito de governamentalidade elaborado por Foucault (2017) em “Microfísica do Poder". Portanto, é uma tentativa de compreender as relações entre o poder e os governos dos vivos, no caso as mulheres que decidem por um parir diferente alicerçada pela análise foucaultiana de discursos.

\section{Resultados e Discussão}

Os discursos encontrados na leitura do livro "Cenas de Partos e Políticas do Corpo" foram selecionados, organizados e discutidos em categorias discursivas. A autora busca em sua obra mapear as práticas e significados de partos naturais, para tanto realizou um estudo etnográfico para alcançar seu propósito. O livro foi, assim, utilizado para compreender dentro de um espaço e um tempo, séc. XXI, como a noção 
de governo dos corpos e da população (as mulheres gestantes) capturam as suas resistências.

A investigação se deu, primeiramente, em um grupo institucional, dentro de um hospital-escola composto de vários profissionais de saúde onde, nas reuniões descritas, percebe-se um poder-saber de várias profissões. "Percebi que a relação hierárquica entre equipe médica e as parturientes prevalecia, sobretudo, a relação à figura do médico coordenador" (CARNEIRO, 2015, p. 96).

O segundo grupo analisado, a autora, descreveu como um grupo independente, devido não ser um grupo institucional. Era um grupo com "mais liberdade e com maior grau de flexibilidade, [...], as mulheres do grupo tornavam-se amigas, confidentes de dilemas e de alegrias" (CARNEIRO, 2015, p. 101). Eram mulheres que diferiam em sua multiplicidade pertenciam as camadas médias, vinculadas a planos de saúde privados, conectadas à internet, o elo que as conectava consistia nas críticas da realidade obstétrica, e obter um parto natural.

O que se destaca nessas mulheres é o pensamento crítico em relação ao hospital, tanto as que pariram pela segunda vez como as de primeira viagem. O desejo e a busca pelo natural soam como liberdade e autonomia, segundo as experiências da autora Carneiro (2015, p. 139) “o termo natural parece o de menos intervenção, de menos controle e de mais autoria e observância do desejado pela mulher que está parindo".

No livro a autora vai trazer depoimentos de grupo de mulheres que buscam esse parir diferente, não só como resposta à medicalização e captura médica sobre o corpo feminino, pois muitas delas negam ser feministas, elas buscam mais um contato com seu interior, em busca de uma mulher que tem a capacidade de gerar e parir, atribuindo mais intensidade e afetação em suas experiências.

São mulheres que buscam um parir diferente a partir de uma ideia de humanização, com menos intervenção, com menos controle e mais autoria, sempre observando os seus desejos no parir. Elas entendem o natural como desprendimento e liberdade de expressão. O parto natural é entendido como reconhecimento de sua singularidade, de sua diferença, de seus anseios e expectativas. Buscam resistir por meio da expressão de suas vontades lutando contra a violência física e simbólica, 
sentem-se capazes de parir, de escolher e decidir que têm corpos saudáveis e que estão aptas a viverem suas experiências conforme suas próprias trajetórias (CARNEIRO, 2015).

Pensa-se que essa renúncia a tantos padrões envolve muito os dispositivos de liberdade e autonomia que compõe a subjetividade das pessoas dentro de um contexto neoliberal. As mulheres em seus direitos reprodutivos, ou seja, direitos de gerar, reproduzir, que estão bem esquadrinhados e organizados nas políticas públicas, nos direitos civis e biomédicos encontram brechas para realizarem a sua parição em casa, longe das normas e dos riscos estabelecidos pela medicina e a tecnologia. Carneiro (2015, p. 284) afirma que as mulheres (entrevistadas) "parecem que são capazes de parir, de escolher e de decidir que têm corpos saudáveis e que se sentem aptas a viver a experiência conforme suas próprias trajetórias".

O discurso pode parecer pouca coisa, mas as interdições que o cercam revelam fortemente suas relações com o desejo e o poder. O discurso detém formas de poder, mas, também, detém aquilo pelo que se luta (SILVA, 2020). Embora fosse um grupo despretensioso, que ao mesmo tempo que vinha denunciar as configurações biomédicas sobre os corpos das mulheres na busca de um parir próprio de cada mulher, era também, um grupo que se colocava como resistência por um desejo.

Ora, analisemos que isso é possível devido ao biopoder, que segundo Foucault (2008) compreende o conjunto dos mecanismos que constituem na espécie humana, suas características biológicas fundamentais, serão capturadas numa estratégia política, numa estratégia geral de poder. O biopoder captura aquilo que é essencial, é próprio do humano, ocorre uma estatização do biológico, ou seja, é uma administração, um controle estatal sobre a vida.

O crescimento urbano e a necessidade de controle sobre as cidades permitiram uma medicina social associada a uma organização de uma política de saúde em que considera as doenças como problemas políticos e econômicos. Uma prática, anteriormente, particular, no interior de seus quartos, na presença de mulheres que se carregavam de cuidar de outras mulheres (parteiras populares), uma prática entre mulheres, o parto foi tornando-se objeto de vigilância estatal, o nascimento e a reprodução passaram a ser focos de atenção do biopoder e da biopolítica. De acordo 
com Gadelha (2009), são modos de regulação e regulamentação do corpo-espécie da população).

Os corpos femininos no que concerne a reprodução e o modo de parir, funcionam como forma de produção de sujeitos e de estratégias de controles. Possibilitando assim um controle maior epidemiológico, um maior controle de natalidade e mortalidade, introduzindo modos econômicos e políticos nesse bem-estar propagado. Dando a maneira correta de cada coisa, com um objetivo adequado apto a ser governado para os seus fins específicos.

A fala daquelas mulheres soam como desapropriadas a um saber e até a uma finalidade, separando entre o que elas desejam e o padrão que deve ser seguido. Ou seja, elas deveriam realizar o pré-natal com o médico especializado, realizar o parto dentro do hospital por ser mais científico e seguro, se submetendo ao parto que seu médico indicar. Em contrapartida, soa o desejo e o grito de uma parição diferente, de acordo com suas experiências e desejos. São discursos separados criando tipos de sujeitos: aquelas que aderem ao saber médico, aquelas que denunciam esse saber, aquelas que se situam em ambas as posições.

Para que o desejo passe a operar como válido manobrará nessa separação e interdição a vontade de verdade, são deslocamentos ao longo da história que permitirá estabelecer formas, domínios dos objetos e técnicas de apoio conferindo aos discursos um status de verdade (FERREIRA; TRAVERSINI, 2013). Se destaca a vontade dessas mulheres de tornar verdade o discurso que elas trazem, que são validadas através da avaliação dos profissionais que participam dos grupos, que levam esses discursos para o âmbito da universidade, dos hospitais, buscando transformá-los em um novo saber. Na medida que vão logrando espaço, se alicerçando na ciência, vão construindo regras, valores e legitimidade.

Para alcançar esses fins específicos o governo tem como alvo as mulheres (uma população), e lançará sobre elas os seus desígnios. A população surge como sujeito de necessidades e também como objeto nas mãos do governo; realiza sua arte de governar através das campanhas de melhorar a sorte da população, aumentar sua riqueza, sua duração de vida, sua saúde. Une o interesse individual e o interesse coletivo como alvo e instrumento do governo da população (FOUCAULT, 2017). 
Só é possível atingir tal controle através da ideia das tecnologias de segurança, pois agem sobre determinada população, elas se apoiam em certos números de dados materiais, maximizando os elementos positivos e minimizando os riscos e os inconvenientes, trabalha com probabilidades, apostando no que pode acontecer no futuro. Segundo Foucault (2008) é a gestão do que pode ser controlado por uma estimativa de probabilidades.

A partir do dispositivo de segurança pode-se analisar a gestão de uma população tão capturada dentro dos mecanismos de poder, tal população são as mulheres. Essa gestão se dá pela governamentalidade. Para Foucault (2017, p. 429), governamentalidade compreende:

O conjunto constituído pelas instituições, procedimentos, análises e reflexões, cálculos e táticas que permitem exercer esta forma bastante específica e complexa de poder, que tem por alvo a população, por forma principal de saber a economia política e por instrumentos técnicos essenciais os dispositivos de segurança.

Esse conceito permitiu levantar questionamentos sobre as escolhas dessas mulheres, descritas no livro, a partir dos relatos de suas experiências, quando todas afirmam uma busca da sua própria experiência de parir conforme sua decisão e liberdade tanto do corpo como da escolha do parto. Os dispositivos de autonomia e liberdade pertencem ao esquadrinhamento de uma biopolítica que subjugam subjetividades livres dentro de um sistema neoliberal e cultural que ensejam normatizações e normalizações de vida das populações (nesse caso mulheres que resistem às cesáreas ou que entregam seus corpos aos cuidados médicos).

O Ministério da Saúde dispõe de um documento, "Plano Nacional de Atenção Integral à Saúde da Mulher", do qual vai decorrer do direito da humanização das práticas de saúde. O que acontece é que muitas mulheres desconhecem seus direitos, embora a atuação da humanização do parto seja bem concreta na realidade. O parto humanizado dispõe de garantias e direitos assegurados em políticas públicas; na Constituição Federal de 1988 quando dispõe da liberdade do corpo da mulher. O ordenamento jurídico atual possibilita uma série de leis que garante tais direitos, por ora é positivo pois possibilita que as mulheres em sua liberdade de exercer seus 
direitos façam a escolha por um parto mais seu; por outro lado há uma captura da vida (aquilo que é essencial), tornando-a objeto das lutas políticas.

A lei só vai permitir que os ideais feministas, tais como: liberdade de escolha, liberdade de dispor sobre o próprio corpo estejam previstos e legalizados, a fim de minimizar as revoltas e torná-los normalizados. Ao mesmo tempo, não irá retirar o controle sobre a vida, seja a criança que irá nascer, ou a mãe que escolhe como fará a gestão daquela vida e o modo que ela virá o mundo. As políticas públicas encontram-se para garantir o modo ideal dessa idealização acontecer. Ainda há o controle de quem e como isso será realizado (aqui seria pauta para novos entendimentos e pesquisas).

Se direitos e garantias já são dados para a execução de escolhas livres de partos, portanto, podemos compreender que os dispositivos liberdade e autonomia, foram também capturados. O que ensejam um governo do Eu, já que mulheres adeptas a tais condutas apresentam estilos de vida semelhantes (veganas, vegetarianas, ecológicas, políticas, ativistas...) e capturadas por um sistema que permite pensar e agir conforme suas supostas necessidades. Ou seja, existe um mercado, filosofias de vida, espiritualidade, alimentação, modo de pensar, uma moda, entre outros; toda uma organização que produz tais modos de pensar e agir. O que se confere aqui é a multiplicidade de mulheres que aderem ao mesmo ideal.

A autora do livro teve dificuldades de padronizar tais mulheres, pois entre elas encontravam-se vegetarianas, as administradoras da antroposofia, as que comiam de tudo, as que priorizavam os cálculos, dados e estatísticas; as que estavam inseridas em âmbitos de trabalho bastante competitivos. Tal multiplicidade de estilo de vida, de norte ético e de espiritualidade implica afirmar a governança naquilo que é próprio do humano os seus desejos, suas vontades. E que ela atinge não a um grupo padronizado, específico, como nas disciplinas; mas a toda população.

Percebe-se como a população das mulheres aparecem como objeto, para o que são dirigidos os mecanismos com intuito de obter sobre ela certo efeito; e também como sujeito, um modo de subjetivar, já que se pede um modo de comportar deste ou daquele jeito. Os dispositivos de segurança garantem em não adotar o ponto de vista 
do que é impedido, nem o ponto de vista do que é obrigatório, mas apreende o ponto em que as coisas vão se produzir, sejam elas desejáveis ou não (FOUCAULT, 2008).

Para os dispositivos de segurança o que importa é a realidade. Irá fazer com que os elementos da realidade atuem uns em relação ao outros através de uma série de análises e de disposições específicas (FOUCAULT, 2008). Aqui podemos evidenciar uma ciência que fala dos benefícios do parto natural para a mulher, como também para o desenvolvimento saudável da criança. E de uma ciência que evidencia os maus tratos obstétricos, a hospitalização e a medicalização da vida.

Todas entrevistadas traziam o discurso da hospitalização e medicalização durante o parto e renunciavam tais ensejos para algo que é próprio delas. Trazer sua experiencia para o ato de parir. Na fala das participantes torna-se nítido a prevalência da vontade:

\footnotetext{
Eu não queria ser separada da minha filha novamente, por isso tomei essa decisão. Eu sabia que podia parir. Nós sabíamos que tudo daria certo. Eu me senti protagonista do meu parto, eu estava mais ativa, com força e consciente de tudo o que se passava, tudo muito diferente dos anteriores (CARNEIRO, 2015, p. 111).
}

A governamentalidade tem como tática a presunção de liberdade e escolha dentro de uma certa cultura. Semeia a liberdade de escolha e na sua própria escolha encontra-se as relações de poder de forma sutil e evidente. A liberdade é ideológica, e principalmente, se realiza como técnica de poder. Segundo Foucault (2008, p. 63), “essa liberdade que ao mesmo tempo ideologia e técnica de governo deve ser compreendida no interior das mutações e transformações das tecnologias de poder".

É por meio da liberdade que se implanta os dispositivos de segurança. Através da liberdade pode-se falar de um governo dos homens (do humano) por meio da administração dessa liberdade, no que querem fazer, no que tem interesse em fazer. É um poder que se dá como regulação. Torna válido aquilo que é tão particular e valioso para as pessoas, a sua própria existência e vivência. Faz-se acreditar que as escolhas são tão nossas, sendo na verdade uma forma de governar, ou seja, nossos ideais são construídos para certos fins. Fins que são sempre lucrativos. 
As sociedades econômicas são marcadas por um Estado de controle sobre a população, mas também, de um Estado econômico que viabiliza a lucratividade. No livro o grupo que a autora fez suas investigações era coordenado por quatro mulheres, duas médicas e duas psicólogas. Segundo Carneiro (2015, p. 100), “além de coordenar os encontros, as quatros mulheres também assistiam aos partos mediante remuneração".

Em outra passagem a autora descreve que a maioria das integrantes dos grupos eram conveniadas a planos de saúde privados, realizavam o pré-natal com seus médicos particulares e optavam por um parto domiciliar custeado com recursos próprios, e algumas pariam nos hospitais credenciados pelos planos de saúde.

Pretende-se destacar que a conduta do parto humanizado tem sua validade e valorização, porém também está vinculado a um sistema econômico, que rende lucratividade tanto para o Estado como para os profissionais envolvidos, movimentando o mercado e rendendo lucro para o país. Cada vez que tais práticas se cristalizam diminuem as despesas hospitalares, a responsabilidade do Estado pela vida que nasce, acentuando o controle da mortalidade e natalidade por meio dos dispositivos de segurança.

Os grupos investigados, o primeiro institucional era oriundo de uma iniciativa pública e o segundo os membros contribuíam para sua manutenção mensal e comercializavam camisetas, vídeos, slings e outros artefatos para bebês e mães que carregavam um logotipo criado para o grupo (CARNEIRO, 2015). Tais condutas demonstram a circulação e a movimentação de um mercado em paralelo a iniciativas e resistência dessas mulheres.

O trabalho não tem a iniciativa de afirmar que o parto humanizado é uma prática errada ou inaceitável, mas pretende lançar uma visão problematizadora sobre certas condutas que possibilitam e evidenciam as condutas de uma população. Ou seja, em detrimento da escolha pelo parto humanizado como resistência e liberdade do próprio corpo, essas mulheres viabilizam o empreendedorismo, comercializam produtos, tornam-se lucrativas ao Estado, logo tornam-se condutas legais. Essas mulheres estão inseridas dentro de um contexto cultural que vende uma sociedade livre, onde as pessoas têm a possibilidades de escolhas, embora elas realmente tenham 
a condição de escolher, mas tais escolhas encontram sujeitadas a um modo de um governo, e aquilo que escapa logo se é capturado e engendrado no modus operandi da governamentalidade neoliberal.

As relações de poder consistem num campo de ações de múltiplas possibilidades, do agir sobre uma população, no agir sobre as ações do outro, até agir sobre a própria conduta (CANDIOTO, 2010). Existem nessa prática uma série de táticas que objetiva a disciplina do corpo e a regulação da população, podendo ser observadas nas políticas públicas, nas garantias e direitos no ordenamento jurídico, no modo de pensar e agir das mulheres.

Com a prática de um parto mais subjetivo, o controle de natalidade e mortalidade ainda é objetivo do Estado, o bem estar da população, tanto das mulheres, como dos filhos nascidos ainda pertence ao controle do Estado, ele ainda faz viver e deixa morrer; as desigualdades ainda reinam entre as camadas sociais, dependendo do poder aquisitivo da mulher, ela pode contratar toda uma equipe especializada para assistir o seu parto; o enxoval do novo ser ainda será um produto comercializado, quanto maior o poder aquisitivo, mais caro e importado será seus novos pertences, muitas dessas mulheres viajam para o exterior para comprar produtos com mais qualidade; as condições de higiene para um parto domiciliar, ainda perpassam o nível econômico e educacional.

O bem-estar físico, a saúde perfeita e a longevidade ainda pertencem a um conjunto de regulamentos e de instituições que monopolizam seus saberes. O exercício dessas três funções é assegurado por meio de mecanismos que asseguram a ordem, o crescimento das riquezas e as condições de manutenção da saúde em geral (FOUCAULT, 2017).

A questão da saúde envolve uma tecnologia das populações, centrando o corpo como portador de múltiplas variáveis, os que são mais ou menos utilizáveis, o que são mais ou menos suscetíveis de investimentos rentáveis, com maior ou menor chance de sobrevivência, capazes de aprendizagem eficaz. Os traços biológicos tornam-se pertinente a uma gestão econômica, sendo necessário organizar um dispositivo que assegure a sua sujeição e o aumento constante de sua utilidade (FOUCAULT, 2017). 
Problematizar o parto humanizado não significa que se deva deixar de realizá-los ou afirmar que as mulheres deixem de escolher conforme sua vontade, pois de fato o ato de conseguir um parto próprio seu configura em resistência (principalmente, resistência a um modelo biomédico e medicalizante). No entanto, as mulheres que optaram pelo parto humanizado, analisadas no livro, se por um lado elas trabalham com a noção de liberdade, de autonomia, de direitos o que podem configurar controle de suas resistências; por outro lado sinalizam que o corpo e a pessoa são não só produtos, como também produtores de cultura (CARNEIRO, 2015).

Em parte, elas rompem com aquilo que é posto, o controle constante, a ameaça de risco e do perigo (elementos de contornos da biopolítica) em busca de uma saúde sem controles, perseguições, em busca de satisfação e de gozo. Em contrapartida, de forma silenciosa a essa resistência é capturada para tornar essa população produtiva.

O governo das pessoas não irá dizer que fazer parto humanizado é ilícito porque traduz em mal-estar para essa mulher ou para sociedade, pelo contrário vai legalizar o grito e a autonomia de suas vontades. A ação de um governo não é a totalidade em forma de proibição, mas sim a população nos seus processos próprios, em seus fenômenos.

A população é a base de riqueza e poderio do Estado, que para funcionar como tal é enquadrado dentro de um aparato regulamentar. Tal aparato garantirá que tal população agirá (ou trabalhará) como, onde e em que convier (FOUCAULT, 2008). As relações deixam de ser jurídicas-políticas, em que o soberano impõe sua vontade através da lei e da cobrança à obediência total delas. Não se trata de obter obediência total de cada indivíduo, atua naquilo que é próprio da população através de cálculos, análises e reflexões.

O que é próprio dessas mulheres que buscam um parir de acordo com sua subjetividade, da sua própria experiência? É o desejo. O desejo de serem respeitadas e atendidas em suas decisões. Segundo Carneiro (2015) por meio do discurso do parto humanizado essas mulheres buscam o reconhecimento de sua singularidade, de sua diferença, de seus anseios e de suas expectativas. 
O desejo permitirá a produção de um interesse, de algo interessante para as populações. Segundo Foucault (2008) é a produção do interesse coletivo que marca a naturalidade das populações e a artificialidade possível dos meios criados para gerilas. É comum vermos mulheres gestantes almejar o parto humanizado (seja ele vaginal ou Cesária), um parto que respeitem sua experiência, sua individualidade e que atinja satisfatoriamente seus anseios.

A escolha de um parto humanizado e a efetivação desse parto tão particular ora é resistência. Porém, há a necessidade das mulheres, em especial, as mulheres gestantes sempre estarem vigilantes às normas vigentes e problematizá-las para que a história das mulheres continue buscando transformações e se afirmando como resistência. Onde há resistência, há poder.

Essas mulheres que se mostram como resistência na busca de um desejo (parir diferente), são capturadas em seu próprio desejo, possibilitando cada vez mais assemelhá-las a consumidoras. E à medida que se tornam mais consumidoras, elas contemplam a vontade do Estado de tornar as pessoas produtivas e lucrativas. Essas relações de poder possibilitam discursos que criam subjetividades maternas e submetidas a elas criam um mercado, formas de lucrar com essas subjetividades.

O governo neoliberal vai legitimar os seus desejos, afirmando que é real, verdadeiro e que não pode agir sem amorosidade. Legitima o discurso subjetivo e cria a partir dele necessidades, como mercado, ciência, desejos, fortalecendo as relações de poder. Pois, nessa perspectiva, o poder só existe se houver resistência; se não há resistência, não há poder (SILVA, 2020). Os procedimentos externos, interdição, separação e rejeição, e vontade de verdade são exercidos no exterior dos discursos tecendo relações específicas de modo a fortalecer ou criar novas relações de poder, fundamentando o conceito foucaultiano de discurso. 


\section{Considerações Finais}

Diante do exposto, a pesquisa demonstra o esquadrinhamento da governamentalidade sobre a liberdade e escolha de um parto humanizado. As mulheres são usadas desses dispositivos para convalidar certas sujeições. Sujeição vinculada não a escolha, mas ao modo de governo, como o Estado se organiza para sobrepor seu poder sobre as populações. Quando liberdade e escolha tornam-se necessária e fundamental para a subjetivação de indivíduos, podemos dizer que aí há uma possibilidade de controle sobre a vida. Pois, a vida tornou-se objeto de controle estatal.

O governo lança a liberdade de sermos donas de si mesmo, por isso tomamos a escolha de parições com menos intervenção médica para uma atitude experenciada como única. O grande problema é que através dessa escolha o governo consegue através do discurso do bem-estar e da qualidade de vida, obter lucratividade e tornar nossas escolhas úteis à economia, à política e às relações sociais. Possibilitando modos de viver, de agir e de sentir.

Foi demonstrado, por meio da obra "Cenas de Parto e Políticas do Corpo", a existência de um mercado entre essas mulheres, a construção de saberes científicos, a formação de opiniões políticas, tornando tais práticas e discursos em um investimento de normalização. Ou seja, tornando tais práticas normais entres as mulheres capturando assim as resistências, normalizando tais condutas dentro de um sistema que torna a vida lucrativa.

Por isso o estudo permite compreender que o parto humanizado embora traga suas vantagens, resistências, suas vicissitudes, ainda é necessária uma visão problematizadora daquilo que nos é lícito. Como o Estado captura nossas resistências para obter vantagens e firmar a biopolítica.

Traçar essa compreensão possibilita problematizar o poder como regulação através da e apoiando-se na liberdade de cada um. Parece um paradoxo, um bem tão buscado, fonte de lutas feministas, a liberdade nos é muito cara, porém, muitas vezes, ela é utilizada para reprimir nossas resistências. Percebe-se isso em boa parte de mulheres um alto grau de ansiedade, com síndromes depressivas, mulheres frustradas 
porque não conseguem responder aos ideais de uma mulher empoderada e dona de si mesmo.

Portanto, a pesquisa pretendeu demonstrar as facetas da governamentalidade como uma rede de estratégias e táticas que são lançadas à população. Captura aquilo que é essencial, natural, próprio do ser humano e torna útil, produtivo e lucrativo para o Estado.

O livro "Cenas de Parto e Políticas do Corpo" foi de suma importância, pois por meio dele foi possível visualizar concretude sutil da ação do governo da vida. É claro que o objetivo do livro não era pontuar as ações de governamentalidade, e sim trazer o poderio das mulheres que através dos seus corpos, de suas ações e escolhas atos concretos de resistência à saúde com seus ditos e verdades; resistências às padronizações do corpo engendrados na biopolítica. São mulheres que em vez de ter seus corpos interditados propuseram a explorá-los e a descobri-los por meio de suas experiências para buscar sua positividade concretizada em suas decisões realizadas, num parir próprio seu, experiências de parto enriquecida e condizente com seus itinerários pessoais.

Porém, a fala e o relato das vivências dessas mulheres realçou questionamentos e inquietações a algo que passaria tão despercebido devido a sua naturalidade. Pois, é justamente nas questões do cotidiano, de nossas vivências mais simples que o governo da vida finca suas estratégias lançando seu poder e o controle sobre as pessoas, tornando-as úteis.

Além disso, ressalta a necessidade de invocar um certo cuidado às sutilidades da vida comum que são tomadas como atos de governo, em que o Estado torna os corpos das mulheres úteis à sua gestão. Como os nossos ideais de luta e resiliência são capturadas e engendrados numa máquina que torna nossos corpos úteis e lucrativos. Invocar esse cuidado é dá validade as questões feministas e reafirmar as nossas lutas. 


\section{Referências}

CANDIOTO, Cesar. A governamentalidade política no pensamento de Foucault. Filosofia Unisinos, São Leopoldo, v. 11, n. 1, p. 33-43, jan./abr. 2010.

CARNEIRO, Rosamaria Giatti. Cenas de parto e políticas do corpo. Rio de Janeiro: Fiocruz, 2015.

FERREIRA, Mauricio dos Santos; TRAVERSINI, Clarice Salete. A análise foucaultiana do discurso como ferramenta metodológica de pesquisa. Educação \& Realidade, Porto Alegre, v. 38, n. 1, p. 207-226, jan./mar. 2013.

FOUCAULT, Michel. A arqueologia do saber. Rio de Janeiro: Forense Universitária, 1997.

FOUCAULT, Michel. Microfísica do poder. 28. ed. Rio de Janeiro: Paz e Terra, 2017.

FOUCAULT, Michel. A ordem do discurso. 20. ed. São Paulo: Loyola, 2010.

FOUCAULT, Michel. Segurança, território e população: curso Collége de France (1977-1978). São Paulo: Martins Fontes, 2008.

GADELHA, Sylvio. Biopolítica, governamentalidade e educação: introdução e conexões, a partir de Michel Foucault. Belo Horizonte: Autêntica, 2009.

SILVA, Marcelo Fábio Peixoto de Araújo Andrade. Uma ordem do discurso: alguns procedimentos de exclusão na campanha "o Brasil que eu quero". Revista Saridh: Linguagem e Discurso, Maranhão, v. 2, n. 1, p. 16-31, 2020.

VENTURA, Miriam. Direitos reprodutivos no Brasil. 3. ed. Brasília, DF: UNFPA, 2009.

WOLLSTONECRAFT, Mary. Reivindicação dos direitos da mulher. São Paulo: Boitempo, 2016. 


\section{1}

Importância da amblêncla para humanização da sala de parto 


\title{
11 IMPORTÂNCIA DA AMBIÊNCIA PARA HUMANIZAÇÃO DA SALA DE PARTO
}

\author{
Raiza Verônica Almeida Barbosa \\ Daniele Vasconcelos Fernandes Vieira \\ Ana Paula da Silva Morais \\ Tatiana Paschoalette Rodrigues Bachur \\ Gislene Holanda de Freitas \\ Marcélid Berto da Costa
}

\section{Resumo}

Objetivo: Analisar a importância da ambiência para humanização da sala de parto e identificar como a ambiência contribui positivamente durante o momento em que a gestante está na sala de parto. Método: Trata-se de um estudo do tipo revisão integrativa, a qual cumpriu criteriosamente seis etapas: 1) Estabelecimento da questão norteadora: "Qual a importância da ambiência para humanização da sala de parto?"; 2) Definição das características das pesquisas primárias da amostra e busca na literatura: foram utilizadas cinco bases de dados, a saber: Scientific Eletronic Library Online (SciELO), Literatura Latino-Americana e do Caribe em Ciências da Saúde (LILACS), Medical Literature Analysis and Retrieval System Online (MEDLINE) e Base de Dados de Enfermagem (BDENF). Foram incluídos artigos completos publicados em português, inglês e espanhol, com resumo disponível na base de dados, no período de 2007 a 2017. Resultados: A produção científica nos últimos dez anos a respeito do tema ainda não é suficiente para construção de uma base bibliográfica de conhecimento em relação ao assunto. Apesar de poucos estudos, é possível concluir que a metodologia de escolha para a pesquisa do tema é geralmente qualitativa. Os estudos mostram que, com o passar dos anos, houve uma maior hospitalização para realização dos partos, e isso modificou o manejo do parto, que passou a ser mais medicalizado, e foi onde surgiu a temática da humanização na sala de parto, e com ela surgiu também a temática da ambiência, que busca tornar o ambiente hospitalar mais humano e digno para a gestante, para seu acompanhante, de livre escolha, e para os profissionais que atuam nesse ambiente. Considerações finais: A utilização da ambiência na sala de parto traz resultados positivos como a diminuição de mortes perinatais, reduz as taxas de cesáreas, maior satisfação tanto para gestante/puérpera como para seus acompanhantes durante processo de pré-parto, parto e puerpério.

Palavras-chaves: Parto Humanizado. Organização e Administração. Enfermagem Obstétrica. 


\section{Introdução}

Durante minha atuação como residente em Saúde da Família e Comunidade (SFC), na Atenção Primária a Saúde (APS) de Fortaleza, sempre me chamaram atenção as consultas de pré-natal. Acredito que seja um programa dentro da Estratégia Saúde Família (ESF) que exige muito do profissional que a realiza, além de ser um momento muito importante para a mulher.

A gestante está cheia de expectativas e dúvidas e cabe ao enfermeiro darlhe algumas informações, objetivando fortalecer e apoiar aquela mulher para que ela chegue na maternidade mais segura e compreendendo os processos pelos quais passará, em cada gestação, seja primípara ou multípara. Os sentimentos da gestante no momento do trabalho de parto podem ser menos dolorosos e até mesmo mais positivos se essa mulher tiver informações corretas sobre o parto, pois assim ela terá mais autonomia e autoconfiança (SILVA; ASCENSO; PAZ, 2017). O ambiente em que a gestante e seu acompanhante irão se deparar ao chegar à maternidade influencia muito na vivência daquele momento. $O$ acolhimento também é um fator muito importante e decisivo para a gestante.

O estágio realizado no Curso de Especialização em Enfermagem Obstétrica da Universidade Estadual do Ceará, em um hospital municipal de Fortaleza, me surgiu esse questionamento sobre a importância da ambiência na sala de parto, sobre como a estrutura da sala de parto pode influenciar positivamente ou negativamente à gestante. Assim, além da ambiência, ressalto a importância do acolhimento, realizado de forma holística e humanizada, considerando o ser biopsicossocial.

O Ministério da Saúde (MS) lançou, em 2004, a Política Nacional de Humanização (PNH) - HumanizaSUS, que é uma política que atravessa diversas ações e instâncias do Sistema Único de Saúde (SUS), englobando os diferentes níveis e dimensões da atenção e da gestão. A política tem como objetivo garantir atenção integral, resolutiva e humanizada através de estratégias e métodos de articulação de ações, saberes, práticas e sujeitos. É estruturada em: princípios, método, diretrizes e dispositivos. Os princípios da PNH são transversalidade, indissociabilidade entre atenção e gestão e protagonismo, corresponsabilidade e autonomia dos sujeitos e dos 
coletivos. O método da PNH caminha no sentido da inclusão, nos processos de produção de saúde, dos diferentes agentes implicados nestes processos. Fala-se sobre um "método de tríplice inclusão": gestores, trabalhadores e usuários no sentido da produção de autonomia, protagonismo e corresponsabilidade (BRASIL, 2010b).

A participação dos usuários é muito importante e deve ser valorizada, uma vez que os cuidados de saúde devem ser de qualidade, adequados e realizados em local apropriado, sempre que necessário. Os enfermeiros, e qualquer outro profissional da área da saúde, assim como os gestores, devem informar e esclarecer os cidadãos de modo, a obter uma participação ativa do cidadão e da comunidade, e assim aumentar os ganhos em saúde, fortalecendo o controle social (RODRIGUES; PENEIRAS; MARTINS, 2013).

Segundo o MS, foram desenvolvidos vários dispositivos na PNH que são acionados nas práticas de produção de saúde, envolvendo coletivos e visando promover mudanças nos modelos de atenção e de gestão, como por exemplo: Acolhimento com Classificação de Risco; Equipes de Referência e de Apoio Matricial; Projeto Terapêutico Singular e Projeto de Saúde Coletiva; Visita Aberta e Direito à Acompanhante; Grupo de Trabalho de Humanização; Câmaras Técnicas de Humanização; entre outros (BRASIL, 2010b). A política tem como diretrizes: o acolhimento, a gestão participativa e cogestão, a ambiência, a clínica ampliada e compartilhada, a valorização do trabalho e do trabalhador e a defesa dos direitos do usuário. Dentre as diretrizes, este trabalho irá se deter nas diretrizes: acolhimento e ambiência.

Segundo a PNH, ambiência é um termo derivado da junção das palavras ambiente e vivência, e aponta para o processo de construção de espaços saudáveis, acolhedores e confortáveis, que respeitem a privacidade, propiciem mudanças no processo de trabalho e considerem todas as dimensões humanas implicadas no processo de ocupação dos espaços para que estes sejam de fato produtores de saúde e lugares de encontro entre as pessoas. A ambiência se dá através da discussão compartilhada dos processos de trabalho, projetos arquitetônicos cogeridos, das reformas e do uso dos espaços de acordo com as necessidades de usuários e trabalhadores de cada serviço (BRASIL, 2010b). 
Tendo em vista a extrema importância de se aplicar o conceito de ambiência na área da obstetrícia, a justificativa para a escolha deste tema é que mesmo com a criação PNH, que trouxe o conceito de ambiência, esse tema ainda é pouco discutido na área.

Desse modo, este trabalho traz como pergunta-problema: "Qual a importância da ambiência para humanização da sala de parto?". Assim, o presente estudo tem como objetivo analisar a importância da ambiência para humanização da sala de parto, identificando como a ambiência contribui positivamente durante o momento em que a gestante está na sala de parto.

\section{Objetivo}

Analisar a importância da ambiência para humanização da sala de parto.

\section{Método}

Trata-se de um estudo do tipo revisão integrativa, que permite a análise de uma complexidade de informação baseada em evidências clínicas constatadas através de estudos já realizados norteados pela Prática Baseadas em Evidência (PBE). Os dados resumidos e comparados permitem com que se obtenha conclusões gerais sobre o problema de pesquisa (CROSSETTI, 2012).

Uma revisão integrativa é um método que admite a incorporação de dados de múltiplos estudos, os dados são elaborados por meio da união e síntese dos resultados da pesquisa e são organizados de maneira sistemática e ordenada. O estudo apresenta uma abordagem qualitativa, que permite maior aproximação com o problema (MENDES; SILVEIRA; GALVÃO, 2008).

A capacidade de identificar e localizar documentos sobre um tópico de pesquisa é uma habilidade importante para o desenvolvimento de um estudo de revisão. Desse modo, a sistematização dos passos para a realização do estudo é fundamental para o desenvolvimento de um trabalho de boa qualidade. No presente estudo, utilizou-se o fluxograma desenvolvido por Mendes; Silveira e Galvão (2008). 
A presente revisão integrativa cumpriu criteriosamente seis etapas: estabelecimento da questão norteadora; definição das características das pesquisas primárias da amostra e busca na literatura; seleção das pesquisas que compuseram a amostra da revisão; análise dos achados dos artigos incluídos na revisão; interpretação dos resultados; e relato da revisão proporcionando um exame crítico dos achados.

Esta busca de evidências iniciou-se com a definição dos descritores e elaboração da questão norteadora que buscasse englobar o objetivo deste estudo: "Qual a importância da ambiência para humanização da sala de parto?"

Avaliou-se a adequação do nível de evidência para o objetivo geral desta pesquisa. Todos os estudos de importância e impacto nos resultados para conclusão do trabalho foram incluídos. Para o levantamento de artigos na realização da revisão foram utilizadas quatro bases de dados, a saber: Scientific Eletronic Library Online (SciELO), Literatura Latino-Americana e do Caribe em Ciências da Saúde (LILACS), Medical Literature Analysis and Retrieval System Online (MEDLINE) e Base de Dados de Enfermagem (BDENF). Desta maneira procuramos ampliar o âmbito da pesquisa, minimizando assim possíveis lacunas nesta etapa de revisão integrativa.

Como critérios de inclusão dos artigos definidos para a presente revisão integrativa foram utilizados: artigos completos publicados em português, inglês e espanhol, com resumo disponível na base de dados, no período de 2007 a 2017, e que retratassem a importância da ambiência para humanização da sala de parto.

Quanto aos critérios de exclusão, não foram incluídos artigos sem resumo, fora do período citado, em outros idiomas que não os explicitados acima e que não se adequavam aos objetivos desta pesquisa. Excluíram-se, ainda, artigos de revisão, monografias, dissertações e teses.

Para localizar os artigos com pertinência para o estudo, utilizou-se de palavras que descrevem o objeto de interesse em busca de contemplar a questão norteadora. Porém, durante as buscas de descritores, não foi encontrado como descritor o termo "ambiência" e isso pode influenciar na sensibilidade da busca dos estudos, o que traz a necessidade de inclusão desse termo como um descritor, devido sua importância e necessidade de mais estudos sobre o assunto. 
Os descritores selecionados são os mais aproximados do tema "ambiência" e foram inseridas palavras relativas ao contexto investigado, utilizando-se, assim, os seguintes descritores: Parto Humanizado; Organização e Administração; Enfermagem Obstétrica.

Quadro 1 - Definição do cruzamento dos descritores. Fortaleza-CE, 2017

\begin{tabular}{|c|c|c|}
\hline \multicolumn{2}{|c|}{ Descritor em Português e Inglês } \\
\hline $\begin{array}{c}\text { Parto Humanizado e Organização e } \\
\text { Administração e Enfermagem } \\
\text { Obstétrica }\end{array}$ & $\begin{array}{c}\text { Parto Humanizado e } \\
\text { Organização e Administração }\end{array}$ & $\begin{array}{c}\text { Parto Humanizado e } \\
\text { Enfermagem } \\
\text { Obstétrica }\end{array}$ \\
\hline A + B + C & A + B & A + C \\
\hline
\end{tabular}

Fonte: Elaboração das autoras.

A busca foi realizada pelo acesso on-line utilizando os descritores já mencionados, de modo que foram encontrados 198 artigos. Estes foram submetidos aos critérios de inclusão previamente descritos. E, como critério de exclusão, foram excluídos, a priori, aqueles artigos que não apresentavam resumos, aqueles que as publicações estavam fora do período estipulado (2007-2017), bem como aqueles que não se apresentavam na versão em português, inglês ou espanhol, os incompletos, assim como as duplicatas.

Após exclusão inicial, realizou-se a leitura dos resumos que estavam disponíveis, avaliando se estes contemplavam os aspectos referentes a importância da ambiência para humanização da sala de parto.

$\mathrm{Na}$ base de dados SciELO foi encontrado 1 artigo na combinação dos descritores $(A+B)$, o qual se enquadrou nos critérios de inclusão. Na combinação $(A+C)$, foram encontrados 48 artigos que após exclusão por critérios já estabelecidos e por duplicidade, resultou em 3 artigos selecionados. A combinação entre os três descritores, $(A+B+C)$, não resultou em nenhum artigo para compor a amostra.

Na BDENF foram encontrados 2 artigos na combinação simultânea dos três descritores $(A+B+C)$, os quais não se enquadraram nos critérios de inclusão. $\mathrm{Na}$ combinação $(A+B)$ foram encontrados 4 artigos que após exclusão por critérios já estabelecidos não resultou em nenhum artigo selecionado. A combinação $(A+C)$ resultou em 69 artigos dos quais 8 foram selecionados a compor a amostra. 
Já na base de dados LILACS, a combinação dos descritores $(A+B+C)$ resultou em 2 artigos encontrados que após seleção foram selecionados para compor a amostra. A combinação $(\mathrm{A}+\mathrm{B})$ resultou em 7 artigos, dos quais nenhum se enquadrou nos critérios de seleção. A combinação $(A+C)$ resultou em 94 artigos, dentre os quais 3 artigos foram selecionados.

$\mathrm{Na}$ base de dados MEDLINE foram encontrados 2 artigos na combinação simultânea dos três descritores $(\mathrm{A}+\mathrm{B}+\mathrm{C})$, no qual apenas 1 artigo foi selecionado. $\mathrm{Na}$ combinação entre $(\mathrm{A}+\mathrm{B})$ foram encontrados 6 artigos, dos quais 1 artigo foi selecionado. Já a combinação $(A+C)$ resultou em 3 artigos, dos quais 1 foi selecionado para compor a amostra. No total, a busca segundo os critérios estabelecidos resultou na seleção de 19 artigos.

Expõem-se 198 estudos em todas as bases, dentre os quais 179 foram excluídos, incluindo estudos duplicados. Para a sua retirada, foi escolhida a base de origem ou a base que apresentasse maior detalhamento do estudo.

A terceira etapa consistiu na definição das informações a serem extraídas dos estudos selecionados, utilizando um instrumento (Apêndice A) para reunir e sintetizar as informações-chave. O revisor tem como objetivo nesta etapa, organizar e sumarizar as informações de maneira concisa, formando um banco de dados de fácil acesso e manejo (SOUZA; SILVA; CARVALHO, 2010).

Os dados extraídos dos artigos foram armazenados no Excel e agrupados em tabelas, figuras e quadros que permitiram melhor visualização e posterior análise de acordo com a literatura pertinente.

Na quarta etapa, foi realizada a análise dos estudos selecionados, norteada pela pergunta de pesquisa (MENDES; SILVEIRA; GALVÃO, 2008). A análise dos dados adotou a seguinte sequência começando pelo título, seguido pelo resumo da investigação e, finalmente, o relatório na sua totalidade.

Os artigos selecionados foram analisados criticamente, procurando explicações para os resultados diferentes ou conflitantes (MENDES; SILVEIRA; GALVÃO, 2008; SOUZA; SILVA; CARVALHO, 2010).

Na quinta etapa, fez-se a discussão dos principais resultados da pesquisa. O revisor, fundamentado nos resultados da avaliação crítica dos estudos incluídos, 
realizou a comparação com o conhecimento teórico, a identificação de conclusões e implicações resultantes da revisão integrativa (MENDES; SILVEIRA; GALVÃO, 2008).

A análise ocorreu de forma textual, ou seja, de acordo com o que foi relacionado entre os autores: resultados de estudos e revisões sistemáticas.

A revisão integrativa deve incluir informações suficientes que permitam ao leitor avaliar a pertinência dos procedimentos empregados na elaboração da revisão, os aspectos relativos ao tópico abordado e o detalhamento dos estudos incluídos (SOUZA; SILVA; CARVALHO, 2010).

A sexta etapa contempla a descrição das etapas percorridas e os principais resultados evidenciados da análise dos artigos incluídos.

Quanto aos aspectos éticos, por se tratar de uma revisão integrativa, não houve a necessidade de avaliação por Comitê de Ética em Pesquisa, pois o material avaliado é de livre acesso na Internet.

\section{Resultados e Discussão}

\section{Ambiência na sala de parto: como a literatura aborda o tema?}

\section{Caracterização geral dos estudos}

Foram investigados 19 artigos cuja análise permitiu obter dados pertinentes ao tema, consistentes com a finalidade do estudo. Essas características são evidenciadas no Quadro 2, conforme descrito a seguir. 
Quadro 2 - Caracterização dos estudos selecionados. Fortaleza-CE, 2017

\begin{tabular}{|c|c|c|c|}
\hline Estudo & $\begin{array}{c}\text { Revista/ Local/ } \\
\text { Ano }\end{array}$ & Título & Objetivo \\
\hline $\begin{array}{l}\text { 1. Behruzi et } \\
\text { al. }\end{array}$ & $\begin{array}{l}\text { BMC } \\
\text { Pregnancy and } \\
\text { Childbirth. } \\
\text { Japão, } 2010\end{array}$ & $\begin{array}{l}\text { Facilitators and barriers } \\
\text { in the humanization of } \\
\text { childbirth practice in } \\
\text { Japan }\end{array}$ & $\begin{array}{l}\text { Explorar a experiência japonesa de parto } \\
\text { infantil em diferentes ambientes de } \\
\text { nascimento onde a humanização do parto } \\
\text { foi identificada entre os objetivos } \\
\text { prioritários das instituições envolvidas e } \\
\text { também explorar os obstáculos e } \\
\text { facilitadores encontrados na prática do } \\
\text { nascimento humanizado nesses centros. }\end{array}$ \\
\hline $\begin{array}{l}\text { 2. Bezerra; } \\
\text { Melo e } \\
\text { Oliveira }\end{array}$ & $\begin{array}{l}\text { Revista de } \\
\text { Enfermagem } \\
\text { UFPE On Line. } \\
\text { Brasil, } 2017\end{array}$ & $\begin{array}{l}\text { Satisfação das } \\
\text { Mulheres Quanto à } \\
\text { Assistência Recebida } \\
\text { da Enfermagem no } \\
\text { Pré-parto }\end{array}$ & $\begin{array}{l}\text { Identificar a satisfação das parturientes } \\
\text { acerca dos cuidados que foram prestados } \\
\text { pela enfermagem no período pré-parto. }\end{array}$ \\
\hline $\begin{array}{l}\text { 3. Costa } \\
\text { Júnior; } \\
\text { Carvalho e } \\
\text { Macedo }\end{array}$ & $\begin{array}{l}\text { Journal of } \\
\text { Research } \\
\text { Fundamental } \\
\text { Care On Line. } \\
\text { Brasil, } 2013\end{array}$ & $\begin{array}{l}\text { Condições } \\
\text { Institucionais } \\
\text { Desfavoráveis à } \\
\text { Presença do } \\
\text { Acompanhante: a } \\
\text { Visão dos Enfermeiros }\end{array}$ & $\begin{array}{l}\text { Compreender as dificuldades encontradas } \\
\text { por enfermeiros que atuam em } \\
\text { maternidades, quanto à garantia da } \\
\text { presença do acompanhante durante o } \\
\text { parto. }\end{array}$ \\
\hline $\begin{array}{l}\text { 4. Freire et } \\
\text { al. }\end{array}$ & $\begin{array}{l}\text { Revista de } \\
\text { Enfermagem } \\
\text { UFPE On Line. } \\
\text { Brasil, } 2017\end{array}$ & $\begin{array}{l}\text { Parto Normal } \\
\text { Assistido por } \\
\text { Enfermeira: } \\
\text { Experiência e } \\
\text { Satisfação de } \\
\text { Puérperas }\end{array}$ & $\begin{array}{l}\text { Descrever a experiência e a satisfação de } \\
\text { mulheres que tiveram parto normal } \\
\text { assistido por enfermeira. }\end{array}$ \\
\hline $\begin{array}{l}\text { 5. Frutoso et } \\
\text { al. }\end{array}$ & $\begin{array}{l}\text { Revista Online } \\
\text { de Pesquisa } \\
\text { Cuidado é } \\
\text { Fundamental. } \\
\text { Brasil, } 2017\end{array}$ & $\begin{array}{l}\text { Percepções do } \\
\text { acompanhante de } \\
\text { escolha da mulher } \\
\text { acerca da organização } \\
\text { e ambiência do centro } \\
\text { obstétrico }\end{array}$ & $\begin{array}{l}\text { Conhecer as percepções do acompanhante } \\
\text { sobre a organização e a ambiência do centro } \\
\text { obstétrico, e identificar quais aspectos } \\
\text { facilitam e dificultam sua permanência. }\end{array}$ \\
\hline $\begin{array}{l}\text { 6. Fujita e } \\
\text { Shimo }\end{array}$ & $\begin{array}{l}\text { Revista } \\
\text { Mineira de } \\
\text { Enfermagem. } \\
\text { Brasil, } 2014\end{array}$ & $\begin{array}{l}\text { Parto Humanizado: } \\
\text { Experiências no } \\
\text { Sistema Único de } \\
\text { Saúde }\end{array}$ & $\begin{array}{l}\text { Relatar a experiência da criação, produção e } \\
\text { divulgação de um documentário popular } \\
\text { sobre parto humanizado no SUS com a } \\
\text { finalidade de informar a população. }\end{array}$ \\
\hline $\begin{array}{l}\text { 7. Giantaglia } \\
\text { et al. }\end{array}$ & $\begin{array}{l}\text { Revista de } \\
\text { Enfermagem } \\
\text { UFPE On Line. } \\
\text { Brasil, } 2017\end{array}$ & $\begin{array}{l}\text { O Cuidado de } \\
\text { Enfermeiras de um } \\
\text { Programa de } \\
\text { Residência Obstétrica } \\
\text { sob o Olhar da } \\
\text { Humanização }\end{array}$ & $\begin{array}{l}\text { Identificar os cuidados oferecidos à mulher, } \\
\text { sob o olhar da humanização no parto e } \\
\text { puerpério, pelas enfermeiras. }\end{array}$ \\
\hline $\begin{array}{l}\text { 8. Gonçalves } \\
\text { et al. }\end{array}$ & $\begin{array}{l}\text { Revista Escola } \\
\text { de } \\
\text { Enfermagem } \\
\text { USP. } \\
\text { Brasil, } 2011\end{array}$ & $\begin{array}{l}\text { Vivenciando o } \\
\text { cuidado no contexto } \\
\text { de uma casa de parto: } \\
\text { o olhar das usuárias }\end{array}$ & $\begin{array}{l}\text { Compreensão da vivência da mulher } \\
\text { parturiente no contexto de uma Casa de } \\
\text { Parto situada em São Paulo. }\end{array}$ \\
\hline $\begin{array}{l}\text { 8. Guida; } \\
\text { Lima e } \\
\text { Pereira }\end{array}$ & $\begin{array}{l}\text { Revista } \\
\text { Mineira de } \\
\text { Enfermagem. } \\
\text { Brasil, } 2013\end{array}$ & $\begin{array}{l}\text { O Ambiente de } \\
\text { Relaxamento Para } \\
\text { Humanização do } \\
\text { Cuidado ao Parto } \\
\text { Hospitalar }\end{array}$ & $\begin{array}{l}\text { Descrever os critérios utilizados pelos } \\
\text { enfermeiros para indicar o ambiente de } \\
\text { relaxamento às parturientes e analisar os } \\
\text { significados, para as enfermeiras }\end{array}$ \\
\hline
\end{tabular}




\begin{tabular}{|c|c|c|c|}
\hline & & & $\begin{array}{l}\text { obstétricas, dos cuidados realizados nesse } \\
\text { ambiente. }\end{array}$ \\
\hline $\begin{array}{l}\text { 10. Motta et } \\
\text { al. }\end{array}$ & $\begin{array}{l}\text { Revista de } \\
\text { Enfermagem } \\
\text { UFPE On Line. } \\
\text { Brasil, } 2016\end{array}$ & $\begin{array}{l}\text { Implementação da } \\
\text { Humanização da } \\
\text { Assistência ao Parto } \\
\text { Natural }\end{array}$ & $\begin{array}{l}\text { Analisar a implementação das práticas } \\
\text { humanizadas na assistência ao parto } \\
\text { natural, fundamentada no documento } \\
\text { "Boas práticas de atenção ao parto e ao } \\
\text { nascimento" de } 1996 .\end{array}$ \\
\hline $\begin{array}{l}\text { 11. Progianti } \\
\text { e Mouta }\end{array}$ & $\begin{array}{l}\text { Revista de } \\
\text { Enfermagem } \\
\text { UERJ. } \\
\text { Brasil, } 2009\end{array}$ & $\begin{array}{l}\text { A Enfermeira } \\
\text { Obstétrica: Agente } \\
\text { Estratégico na } \\
\text { Implantação de } \\
\text { Práticas do Modelo } \\
\text { Humanizado em } \\
\text { Maternidades }\end{array}$ & $\begin{array}{l}\text { Analisar as estratégias utilizadas para } \\
\text { implantar o modelo humanizado na } \\
\text { Maternidade Municipal Leila Diniz, } \\
\text { localizada no Rio de Janeiro. }\end{array}$ \\
\hline $\begin{array}{l}\text { 12. Progianti } \\
\text { e Porfírio }\end{array}$ & $\begin{array}{l}\text { Escola Anna } \\
\text { Nery Revista } \\
\text { de } \\
\text { Enfermagem. } \\
\text { Brasil, } 2012\end{array}$ & $\begin{array}{l}\text { Participação das } \\
\text { Enfermeiras no } \\
\text { Processo de } \\
\text { Implantação de } \\
\text { Práticas Obstétricas } \\
\text { Humanizadas na } \\
\text { Maternidade } \\
\text { Alexander Fleming } \\
(1998-2004)\end{array}$ & $\begin{array}{l}\text { Analisar o processo de inserção das } \\
\text { enfermeiras na assistência ao parto e as } \\
\text { lutas dessas profissionais para implantar as } \\
\text { práticas obstétricas humanizadas na } \\
\text { Maternidade Alexander Fleming. }\end{array}$ \\
\hline 13. Reis et al. & $\begin{array}{l}\text { Revista Online } \\
\text { de Pesquisa } \\
\text { Cuidado é } \\
\text { Fundamental. } \\
\text { Brasil, } 2016\end{array}$ & $\begin{array}{l}\text { Análise de partos } \\
\text { acompanhados por } \\
\text { enfermeiras obstétricas } \\
\text { na perspectiva da } \\
\text { humanização do parto } \\
\text { e nascimento }\end{array}$ & $\begin{array}{l}\text { Analisar partos acompanhados pelas } \\
\text { enfermeiras obstétricas relacionando sua } \\
\text { prática com a política de humanização do } \\
\text { parto e nascimento. }\end{array}$ \\
\hline $\begin{array}{l}\text { 14. Silva; } \\
\text { Barbieri e } \\
\text { Fustinoni }\end{array}$ & $\begin{array}{l}\text { Revista } \\
\text { Brasileira de } \\
\text { Enfermagem. } \\
\text { Brasil, } 2011\end{array}$ & $\begin{array}{l}\text { Vivenciando a } \\
\text { experiência da } \\
\text { parturição em um } \\
\text { modelo assistencial } \\
\text { humanizado }\end{array}$ & $\begin{array}{l}\text { Compreender as experiências de puérperas } \\
\text { que vivenciaram o trabalho de parto e o } \\
\text { parto em um modelo assistencial } \\
\text { humanizado. }\end{array}$ \\
\hline $\begin{array}{l}\text { 15. Silva; } \\
\text { Nascimento } \\
\text { e Coelho }\end{array}$ & $\begin{array}{l}\text { Escola Anna } \\
\text { Nery Revista } \\
\text { de } \\
\text { Enfermagem. } \\
\text { Brasil, } 2015\end{array}$ & $\begin{array}{l}\text { Práticas de } \\
\text { enfermeiras para } \\
\text { promoção da } \\
\text { dignificação, } \\
\text { participação e } \\
\text { autonomia de } \\
\text { mulheres no parto } \\
\text { normal }\end{array}$ & $\begin{array}{l}\text { Conhecer as práticas de cuidado utilizadas } \\
\text { por enfermeiras implicadas nos processos } \\
\text { autonomia, dignificação e participação de } \\
\text { mulheres durante o parto normal. }\end{array}$ \\
\hline $\begin{array}{l}\text { 17. Souza et } \\
\text { al }\end{array}$ & $\begin{array}{l}\text { Journal of } \\
\text { Research } \\
\text { Fundamental } \\
\text { Care On Line. } \\
\text { Brasil, } 2013\end{array}$ & $\begin{array}{l}\text { Equipe de } \\
\text { Enfermagem e os } \\
\text { Dispositivos de } \\
\text { Cuidado no Trabalho } \\
\text { de Parto: Enfoque na } \\
\text { Humanização }\end{array}$ & $\begin{array}{l}\text { Conhecer os dispositivos que possibilitam a } \\
\text { humanização do cuidado no cotidiano da } \\
\text { equipe de enfermagem durante o processo } \\
\text { de parturição. }\end{array}$ \\
\hline $\begin{array}{l}\text { 18. Vargens; } \\
\text { Silva e } \\
\text { Progianti }\end{array}$ & $\begin{array}{l}\text { Escola Anna } \\
\text { Nery Revista } \\
\text { de }\end{array}$ & $\begin{array}{l}\text { Contribuição de } \\
\text { enfermeiras obstétricas } \\
\text { para consolidação do } \\
\text { parto humanizado em }\end{array}$ & $\begin{array}{l}\text { Identificar as práticas empregadas por } \\
\text { enfermeiras obstétricas na assistência ao } \\
\text { parto em maternidades públicas e sua }\end{array}$ \\
\hline
\end{tabular}




\begin{tabular}{|l|l|l|l|}
\hline & $\begin{array}{l}\text { Enfermagem. } \\
\text { Brasil, 2017 }\end{array}$ & $\begin{array}{l}\text { maternidades no Rio } \\
\text { de Janeiro-Brasil }\end{array}$ & $\begin{array}{l}\text { contribuição na consolidação da } \\
\text { humanização do parto e nascimento. }\end{array}$ \\
\hline $\begin{array}{l}\text { 19. Versiani } \\
\text { et al. }\end{array}$ & $\begin{array}{l}\text { Journal of } \\
\text { Research } \\
\text { Fundamental } \\
\text { Care On Line. } \\
\text { Brasil, 2015 }\end{array}$ & $\begin{array}{l}\text { Significado de parto } \\
\text { humanizado para } \\
\text { gestantes }\end{array}$ & $\begin{array}{l}\text { Compreender o significado de parto } \\
\text { humanizado na concepção de gestantes. }\end{array}$ \\
\hline
\end{tabular}

Fonte: Elaboração das autoras.

O Quando 2 demonstra que os estudos referentes à importância da ambiência na sala de parto, ainda são incipientes, com uma frequência baixa de estudos ao longo da última década: zero em 2007; zero em 2008; 1 em 2009; 3 em 2010; zero em 2011; passando para 1 em 2012; 3 em 2013; 1 em 2014; mais 3 em 2015, 2 em 2016, 5 em 2017. O Gráfico 1 mostra, temporalmente, essa produção.

A diminuta produção de conhecimento, percebida nesse estudo, tem reflexos, também, na prática profissional, uma vez que é indispensável que profissionais do campo da saúde conheçam a $\mathrm{PNH}$, a fim de que proporcionem assistência de qualidade, promovendo, assim, o encontro, ambiência, acolhimento e reconhecimento de si mesmo, do outro e de sua profissão (SILVA; OLIVEIRA; PEREIRA, 2015).

Enfatiza-se, com isso, que ambiente físico e o apoio de profissionais são indissociáveis da prática de cuidado e que quando se considera a assistência obstétrica centrada nas necessidades da parturiente é importante considerar o direito à autonomia da mulher, o acesso dela às informações de qualidade e a sua participação ativa dentro do processo parturitivo em um ambiente adequado.

\section{Aspectos metodológicos dos estudos da amostra}

Quanto ao delineamento dos estudos observou-se que há um aprofundamento no tema estudado, visto que as pesquisas mostram, em sua maioria, desenhos descritivos, debruçando-se na questão da importância da ambiência na sala de parto.

Desse modo temos a distribuição dos estudos em: 8 descritivos, 1 relato de experiência, 2 estudos histórico-social, 2 transversais e descritivos, 3 exploratórios e 
descritivos, 1 retrospectivo e descritivo, 2 descritivos baseados na abordagem fenomenológica. Em relação à natureza das pesquisas, 17 são de natureza qualitativa, e 2 somente de natureza quantitativa.

É importante notar, pelo exposto no Quadro 2, que a abordagem qualitativa é preferencialmente utilizada nos estudos que compuseram a amostra. Segundo Minayo (2012b), a abordagem qualitativa aprofunda-se no mundo dos significados das ações e relações humanas. Configura-se, dessa forma, como a abordagem mais adequada frente a um fenômeno subjetivo, aos sentimentos e percepções do sujeito investigado, como algo não passível de quantificação.

Assim, por "trabalhar com o universo de significados, dos motivos, das aspirações, das crenças, dos valores e das atitudes" (MINAYO, 2012b, p. 21), a pesquisa qualitativa favoreceu a percepção da importância da ambiência na sala e parto. Assim, pesquisas qualitativas mostram que a vivência de cada um sobre o mesmo episódio é única e depende de sua personalidade, de sua biografia e de sua participação na história (MINAYO, 2012a).

\section{A ambiência e humanização na sala de parto}

Alguns estudos iniciaram mostrando que com o passar dos anos houve uma troca do ambiente em que os partos são feitos, visto que passaram a ser realizados, em sua grande maioria, em ambiente hospitalar, o que modificou a percepção do trabalho de parto, que antes eram realizados por parteiras na própria casa das parturientes. Com essa mudança de ambiente, o parto tornou-se algo mecânico, medicalizado, onde a autonomia da mulher praticamente não existe (VARGENS; SILVA; PROGIANTI, 2017; GONÇALVES et al., 2011; SILVA; BARBIERI; FUSTINONI, 2011; GIANTAGLIA et al., 2017; MOTTA et al., 2016; SOUZA et al., 2013).

Atualmente, o que se observa é que o campo obstétrico, no ambiente hospitalar, está tendo que se adaptar constantemente para que atenda à perspectiva da humanização do parto. Assim, a enfermagem obstétrica está ocupando espaço ao desenvolver tecnologias não invasivas de cuidado de enfermagem obstétrica (TNICE), que têm como características marcantes a compreensão do parto como um processo 
fisiológico, o respeito à sua natureza e à integridade corporal e psíquica das mulheres. As TNICE fazem parte do modelo humanizado e vêm sendo amplamente utilizadas, seja na diminuição do tempo do trabalho de parto ou aliviando a dor e configuram-se como importante estratégia no processo de humanização (VARGENS; SILVA; PROGIANTI, 2017).

Portanto, a enfermagem obstétrica é uma importante aliada para a humanização e ambiência e surgiu em diversos estudos como agente estratégico nas maternidades, tanto na gestão como na atuação diária. A assistência obstétrica é centrada nas necessidades da parturiente é importante considerar o direito à autonomia da mulher, o acesso dela às informações de qualidade e a participação ativa da mesma dentro do processo parturitivo (PROGIANTI; MOUTA, 2009; SILVA; NASCIMENTO; COELHO, 2015; FUJITA; SHIMO, 2014; FREIRE et al., 2017; BEZERRA; MELO; OLIVEIRA, 2017).

Em estudo realizado em maternidade pública do Rio de Janeiro, com objetivo de analisar partos acompanhados pelas enfermeiras obstétricas relacionando sua prática com a política de humanização do parto e nascimento, os resultados evidenciaram que $42,42 \%$ das parturientes que foram acompanhadas pelas enfermeiras obstétricas passaram por todo o processo da parturição sem que fosse adotada nenhuma conduta intervencionista e isso demonstra que o processo de desmedicalização do parto e nascimento é possível de acontecer, mesmo em ambiente que, a princípio, se mostre adverso (REIS et al., 2016).

Um estudo realizado em São Paulo, em 2010, trouxe a casa de parto natural como um serviço propício à ambiência e a humanização, pois tem uma estrutura física diferente da estrutura hospitalar. Foi evidenciado que há uma melhor relação profissional-usuário e seus mobiliários e instalações representam um componente importante do cuidado recebido. A casa de parto foi descrita pelas mulheres como um ambiente mais leve e tranquilo quando comparada aos hospitais tradicionais e os resultados evidenciaram que a mulher que escolhe a casa de parto para dar à luz busca pelo cuidado humanizado (GONÇALVES et al., 2011).

Segundo Versiani et al. (2015), a assistência humanizada deve aflorar algumas características essenciais do ser humano como a sensibilidade, o respeito e a 
dignidade, criando um ambiente acolhedor dotado de condutas institucionais que rompam com o tradicional isolamento imposto à mulher. Além disso, deve ainda garantir segurança e a realização de procedimentos que tragam benefícios tanto para a mulher quanto para o recém-nascido, ressaltando o resgate da sua autonomia por ocasião do parto.

Para Guida; Lima e Pereira (2013), a manutenção do ambiente silencioso e a promoção do conforto e relaxamento no trabalho de parto são cuidados que devem ser instituídos, pois são necessários para que os fenômenos fisiológicos envolvidos no processo da parturição ocorram de forma adequada, como a liberação de ocitocina e endorfinas endógenas, a fim de que seja facilitando o curso normal do trabalho de parto. A assistência de enfermagem obstétrica deve promover o conforto e o empoderamento da mulher no trabalho de parto e no parto, contribuindo para que ela, seu cônjuge e sua família vivenciem o momento do nascimento como único, singular e irrepetível.

Quase todos os estudos encontrados e selecionadas para esta pesquisa foram realizados no Brasil, porém, um deles foi realizado no Japão e teve como objetivo explorar a experiência japonesa de parto infantil em diferentes ambientes de nascimento onde a humanização do parto foi identificada entre os objetivos prioritários das instituições envolvidas, assim como explorar os obstáculos e facilitadores encontrados na prática do nascimento humanizado nesses centros. Os resultados obtidos nesse estudo foram semelhantes aos encontrados nos estudos brasileiros, e mostraram que todas as configurações dos hospitais estudados implementaram estratégias visando reduzir o número de cesáreas e manter o parto o mais natural possível (BEHRUZI et al., 2010).

Os estudos mostraram que, para que a PNH se consolide, modificações na organização e na arquitetura dos centros obstétricos se fazem necessárias, pois ainda permanece a arquitetura tradicional do pré-parto e, nesse tipo de arquitetura, o conforto e a privacidade das parturientes ficam comprometidos, constituindo-se em um espaço assistencial pouco favorável à fisiologia do parto e nascimento. A ambiência deve, então, atender a todos, tanto as mulheres gestantes, como seus acompanhantes, como os profissionais que atuam naquele ambiente (GUIDA; LIMA; 
PEREIRA, 2013; GIANTAGLIA et al., 2017; SILVA; BARBIERI; FUSTINONI, 2011; COSTA JÚNIOR; CARVALHO; MACEDO, 2013).

\section{Considerações Finais}

Os estudos mostram que com o passar dos anos, houve uma troca do ambiente em que os partos são feitos, passando a haver uma maior hospitalização para realização dos partos, p que modificou o manejo do parto, que passou a ser mais medicalizado, tecnicista. A partir disso, surgiu a temática da humanização na sala de parto, e com ela surgiu também a temática da ambiência, que busca tornar o ambiente hospitalar mais humano e digno para a gestante, para seu acompanhante, de livre escolha, e para os profissionais que atuam nesse ambiente.

A ambiência na sala de parto foi percebida como algo positivo, e sua utilização traz benefícios como a diminuição de mortes perinatais, diminuição das taxas de cesáreas, maior satisfação tanto para gestante/puérpera como para seus acompanhantes durante processo de pré-parto, parto e puerpério. É importante que alterações estruturais sejam realizadas nas maternidades, para que sejam atendidas as demandas da PNH, e que essas orientações levem em conta além dos usuários, os trabalhadores dos serviços.

Devido a diminuta quantidade e baixa especificidade de artigos sobre o tema sugere-se que sejam realizadas pesquisas de campo e/ou pesquisas-ação para que seja avaliada melhor a importância da ambiência na sala de parto.

Embora a PNH tenha sido criada há mais de dez anos, ainda se percebe a dificuldade em se seguir seus princípios e diretrizes, dentre elas a ambiência. Porém acredita-se que essa adaptação à PNH está em processo, ainda que bem longe do ideal.

A enfermagem obstétrica atua com o objetivo de alcançar os princípios e diretrizes da $\mathrm{PNH}$, favorecendo partos realizados em ambientes propícios, onde a mulher se sinta segura, empoderada e com autonomia sobre o momento do seu parto. 


\section{Referências}

BEHRUZI, Roxana et al. Facilitators and barriers in the humanization of childbirth practice in Japan. BMC Pregnancy and Childbirth, v. 10, n. 25, p. 1-18, May 2010.

BEZERRA, Héllyda de Souza; MELO, Túlio Felipe Vieira de; OLIVEIRA, Danielly Azevedo. Satisfação das mulheres quanto à assistência recebida da enfermagem no pré-parto. Revista de Enfermagem UFPE On Line, Recife, v. 11, n. 5, p. 1852-1857, maio 2017. Disponível em:

https://periodicos.ufpe.br/revistas/revistaenfermagem/article/view/23333. Acesso em: 7 set. 2021.

BRASIL. Ministério da Saúde. Política Nacional de Humanização (PNH): cartilha da PNH: ambiência. Brasília, DF: Ministério da Saúde, 2006.

BRASIL. Ministério da Saúde. Secretaria de Atenção à Saúde. Ambiência. 2. ed. Brasília, DF: Ministério da Saúde, 2010.

BRASIL. Ministério da Saúde. Secretaria de Atenção à Saúde. Política Nacional de Humanização. Formação e intervenção. Brasília, DF: Ministério da Saúde, 2010.

BRASIL. Portaria $n^{\circ} 1.459$, de 24 de junho de 2011. Institui, no âmbito do Sistema Único de Saúde - SUS - a Rede Cegonha. Diário Oficial [da] República Federativa do Brasil: seção 1, p. 109, 27 jun. 2011.

COSTA JÚNIOR, Pedro Bernardino; CARVALHO, Isaiane da Silva; MACEDO, Janile Bernardo Pereira de Oliveira. Condições institucionais desfavoráveis à presença do acompanhante: a visão dos enfermeiros. Journal of Research Fundamental Care On Line, v. 5, n. 4, p. 671-680, out./dez. 2013. Disponível em:

http://www.seer.unirio.br/index.php/cuidadofundamental/article/view/2354/pd f_945. Acesso em: 7 set. 2021.

CROSSETTI, Maria da Graça Oliveira. Revisão integrativa de pesquisa na enfermagem o rigor científico que lhe é exigido. Revista Gaúcha de Enfermagem, Porto Alegre, v. 33, n. 2, jun. 2012. Editorial.

DODOU, Hilana Dayana et al. Sala de parto: condições de trabalho e humanização da assistência. Cadernos Saúde Coletiva, v. 25, n. 3, p. 332-338, 2017. Disponível em: http:// www.scielo.br/scielo.php?script=sci_arttext\&pid=S1414462X2017000300332\&lng=pt\&nrm=iso. Acesso em: 10 dez. 2017.

FREIRE, Hyanara Sâmea de Sousa et al. Parto normal assistido por enfermeira: experiência e satisfação de puérperas. Revista de Enfermagem UFPE On Line, Recife, v. 11, n. 6, p. 2357-2367, jun. 2017. 
FRUTUOSO, Letícia Demarche et al. Percepções do acompanhante de escolha da mulher acerca da organização e ambiência do centro obstétrico. Revista de Pesquisa Cuidado é Fundamental Online, v. 9, n. 2, p. 363-370, abr./jun. 2017. Disponível em: http://www.seer.unirio.br/cuidadofundamental/article/view/4928/pdf_1. Acesso em: 7 set. 2021.

FUJITA, Júnia Aparecida Laia da Mata; SHIMO, Antonieta Keiko Kakuda. Parto humanizado: experiências no Sistema Único de Saúde. Revista Mineira de Enfermagem, v. 18, n. 4, p. 1011-1015, out./dez. 2014.

GIANTAGLIA, Fernanda Nogueira et al. O cuidado de enfermeiras de um programa de residência obstétrica sob o olhar da humanização. Revista de Enfermagem UFPE On Line, Recife, v. 11, n. 5, p. 1882-1890, 2017.

GONÇALVES, Roselane et al. Vivenciando o cuidado no contexto de uma casa de parto: o olhar das usuárias. Revista Escola de Enfermagem USP, São Paulo, v. 45, n. 1, p. 62-70, 2011.

GUIDA, Natasha Faria Barros; LIMA, Gabrielle Parrilha Vieira; PEREIRA, Adriana Lenho de Figueiredo. $\mathrm{O}$ ambiente de relaxamento para humanização do cuidado ao parto hospitalar. Revista Mineira de Enfermagem, v. 17, n. 3, p. 524-530, jul./ set. 2013.

MARINHO, O. L. D. A humanização e a arte do cuidar: a visão do enfermeiro sobre humanização no processo de cuidar. Nursing, n. 268, abr. 2011.

MENDES, Karina Dal Sasso; SILVEIRA, Renta Cristina de Campos Pereira; GALVÃO, Cristina Maria. Revisão integrativa: método de pesquisa para a incorporação de evidências na saúde e na enfermagem. Texto \& Contexto Enfermagem, Florianópolis, v. 17, n. 4, p. 758-764, out./dez. 2008.

MINAYO, Maria Cecília de Souza. Análise qualitativa: teoria, passos e fidedignidade. Ciência \& Saúde Coletiva, v. 3, n. 17, p. 621-626, 2012a.

MINAYO, Maria Cecília de Souza (org.). Pesquisa social: teoria, método e criatividade. 31. ed. Petrópolis: Vozes, 2012 b.

MOTTA, Silvia Adrya Martins Franco et al. Implementação da humanização da assistência ao parto natural. Revista de Enfermagem UFPE On Line, Recife, v. 10, n. 2, p. 593-599, fev. 2016.

PESSATTI, Mirela Pessatti. Ambiência para o parto e nascimento. In: OFICINA, 2012, Belo Horizonte. Slides de Apresentação [...]. Belo Horizonte: Ministério da Saúde: Maternidades de Belo Horizonte: Hospital Sofia Feldman, 2012. 
PROGIANTI, Jane Márcia; MOUTA, Ricardo José Oliveira. A enfermeira obstétrica: agente estratégico na implantação de práticas do modelo humanizado em maternidades. Revista de Enfermagem UERJ, v. 17, n. 2, p. 165-169, abr./jun. 2009.

PROGIANTI, Jane Márcia; PORFÍRIO, Aline Bastos. Participação das enfermeiras no processo de implantação de práticas obstétricas humanizadas na Maternidade Alexander Fleming (1998-2004). Escola Anna Nery Revista de Enfermagem, Rio de Janeiro, v. 16, n. 3, p. 443-450, jul./set. 2012.

REIS, Carlos Sérgio Corrêa dos et al. Análise de partos acompanhados por enfermeiras obstétricas na perspectiva da humanização do parto e nascimento.

Revista de Pesquisa Cuidado é Fundamental On Line, v. 8, n. 4, p. 4972-4979, out./dez. 2016. Disponível em:

http:// www.seer.unirio.br/index.php/cuidadofundamental/article/view/3966. Acesso em: 7 set. 2021.

RODRIGUES, Sofia Inês Borges; PENEIRAS, Maria Fátima Lopes; MARTINS, Maria José Rosado. A acessibilidade aos cuidados de saúde. Nursing Magazine Digital, ano 26, n. 289, p. 1-12, dez. 2013. Disponível em:

https://www.researchgate.net/publication/314658213_A_acessibilidade_aos_cuida dos_de_saude. Acesso em: 7 set. 2021.

SILVA, Andréa Lorena Santos; NASCIMENTO, Enilda Rosendo do; COELHO, Edméia de Almeida Cardoso. Práticas de enfermeiras para promoção da dignificação, participação e autonomia de mulheres no parto normal. Escola Anna Nery Revista, Rio de Janeiro, v. 19, n. 3, p. 424-431, 2015.

SILVA, Larissa Mandarano da; BARBIERI, Márcia; FUSTINONI, Suzete Maria. Vivenciando a experiência da parturição em um modelo assistencial humanizado. Revista Brasileira de Enfermagem, v. 64, n. 1, p. 60-65, jan./fev. 2011.

SILVA, M. G. B. B.; ASCENSO, M. P. F.; PAZ, S. D. C. Cuidar em sala de partos. Nursing, 27 jun. 2017.

SILVA, Rose Mary Costa Rosa Andrade; OLIVEIRA, Denize Cristina de; PEREIRA, Eliane Ramos. The discursive production of professionals about humanizing health singularity, rights and ethics. Revista Latino-Americana de Enfermagem, v. 23, n. 5, p. 936-944, set./out. 2015.

SOUZA, Camila Maria de et al. Equipe de enfermagem e os dispositivos de cuidado no trabalho de parto: enfoque na humanização. Journal of Research Fundamental Care On Line, v. 5, n. 4, p. 743-754, out./dez. 2013. Disponível em: https://dialnet.unirioja.es/servlet/articulo?codigo=4767959. Acesso em: 7 set. 2021. 
SOUZA, Marcela Tavares de; SILVA, Michelly Dias da; CARVALHO, Rachel de. Revisão integrativa: o que é e como fazer. Einstein, São Paulo, v. 8, n. 1, p. 102-106, 2010.

VARGENS, Octavio Muniz da Costa; SILVA, Alexandra Calento Vasconcellos da; PROGIANTI, Jane Márcia. Contribuição de enfermeiras obstétricas para consolidação do parto humanizado em maternidades no Rio de Janeiro-Brasil. Escola Anna Nery, Rio de Janeiro, v. 21, n. 1, p. 1-8, 2017.

VERSIANI, Clara de Cássia et al. Significado de parto humanizado para gestantes. Revista de Pesquisa Cuidado é Fundamental Online, v. 7, n. 1, p. 1927-1935, jan./mar. 2015. 


\section{2}

Percepģão do professor de Educação Física sobre a inserção das práticas integrativase complementares em saúde no contexto escolarno municíplo de Maracanaú- CE 


\title{
12 PERCEPÇÃO DO PROFESSOR DE EDUCAÇÃO FÍSICA SOBRE A INSERÇÃO DAS PRÁTICAS INTEGRATIVAS E COMPLEMENTARES EM SAÚDE NO CONTEXTO ESCOLAR NO MUNICÍPIO DE MARACANAÚ-CE
}

\author{
Sabrina Cavalcante Rodrigues \\ Daniele Vasconcelos Fernandes Vieira \\ Cláudio Henrique Couto do Carmo \\ Emanuele Ribeiro Ramos \\ Jeania Lima Oliveira \\ Marcos Aurélio Silva de Sousa
}

\section{Resumo}

Objetivo: Realizar uma análise da perspectiva do Professor de Educação Física sobre a inserção das Práticas Integrativas Complementares em Saúde no ambiente escolar no município de Maracanaú-Ceará. Método: Foi realizada uma análise situacional como proposta metodológica para estabelecer orientações quanto à resolução dos problemas tratados pela incorporação das Práticas Integrativas e Complementares em Saúde no contexto escolar. A pesquisa foi realizada com 13 professores de escolas do município conveniadas com o Programa Saúde na Escola (PSE), sendo utilizada como técnica de coleta e dados uma entrevista estruturada que possibilitou a construção do agrupamento de percepções docentes a partir do qual foi possível delinear o terreno analítico da situação da Política Nacional de Práticas Integrativas e Complementares em Saúde na Profissão de Professor de Educação Física na escola neste município específico. Resultados: Evidenciamos nas falas dos professores a falta de conhecimento sobre as Práticas Integrativas e Complementares em Saúde (PIC), ausência mencionada desde a grade curricular nos Cursos de Educação Física, até suas formações e orientações pedagógicas. Porém foi percebido que após apresentação das 29 PIC citada no checklist tornou-se ciente o reconhecimento da sua importância no ambiente escolar, quanto aos benefícios que tais práticas vêm contribuir na formação integral dos alunos. Considerações finais: Considerando que o conhecimento sobre as PIC, é relevante à abertura para sua inserção nas escolas do Município de Maracanaú, fazendo necessário à sua valorização desde a matriz curricular acadêmica nos Cursos de Educação Física até as formações continuadas desses professores por iniciativas municipais em capacitações e especializações.

Palavras-chave: Práticas Integrativas. Complementares em Saúde. Professor de Educação Física. PIC na Escola. 


\section{Introdução}

As Práticas integrativas complementares no contexto escolar têm se constituído um importante estímulo de reflexão e pesquisa, definido como o nosso objeto de estudo. O seu despertar veio a partir de uma apresentação superficial do conteúdo PIC na disciplina de especialização em Educação Física escolar, juntamente com as leituras iniciais de suas diretrizes. As inquietações advindas estimularam a vontade de construir um projeto de iniciação científica como uma forma de buscar conhecimentos pertinentes ao tema e dessa maneira conseguir analisar as possibilidades de atuação das PIC no contexto escolar pelos Professores de Educação Física.

A partir desse despertar, surgiu o interesse em analisar o conhecimento e as aberturas que as Escolas Públicas do município de Maracanaú oferecem para implantação e implementação das práticas integrativas e complementares na Educação dos jovens, bem como o conhecimento dos Professores de Educação Física sobre essas práticas e a repercussão no desenvolvimento das crianças e dos adolescentes.

Percebeu-se, porém, a ausência dos conteúdos das PIC na grade curricular acadêmica dos Cursos de Educação Física. Emergindo então interrogações a respeito da relevância do conteúdo na formação acadêmica dos profissionais de Educação física, a sua possível atuação na escola e sua aplicabilidade no contexto escolar.

O que diz a Lei de Diretrizes e Bases da Educação Nacional nº 9.394/96 (BRASIL, 1996), os Parâmetros Curriculares Nacionais (BRASIL, 1997) e as Diretrizes Curriculares Nacionais Gerais para a Educação Básica (BRASIL, 2018). Frente aos diálogos no âmbito nacional que envolvem as questões relacionadas à saúde da criança e do adolescente no contexto escolar, baseando-se nos referenciais documentais mencionados, que evidenciam a presença das práticas de saúde na rotina escolar e a articulação dos Professores de Educação Física para a implementação das mesmas, propõe-se compreender como as escolas e os próprios professores incorporam essas questões nas suas estratégias pedagógicas e no seu trabalho cotidiano com as crianças e os adolescentes. 
Com uma abordagem humanizada, as PIC se integram à natureza por meio de recursos simples e terapêuticos, que buscam promover o equilíbrio entre o corpo, mente e espírito conforme as diretrizes da Organização Mundial de Saúde (OMS). No Brasil, a legitimação e a institucionalização dessas abordagens de atenção à saúde ocorreram a partir da Portaria $n^{0} 971$ que aprova a Política Nacional de Práticas Integrativas (BRASIL, 2006).

Por isso é relevante conhecermos, sob a perspectiva do Professor de Educação Física o que sabem sobre as PIC, como percebem essa política em sua prática docente inserido na escola e quais as facilidades, desafios e avanços o seu ambiente de trabalho tem oferecido para que de fato essa articulação da Política Nacional de Práticas Integrativas e Complementares com a Escola seja efetivada.

A Política é um documento que normatiza as práticas das PIC em sistemas de saúde complexos e recursos terapêuticos, responsabilizando as instituições em ofertar serviços e produtos das práticas integrativas complementares a fim de ampliar as abordagens de cuidado e de possibilidades terapêuticas garantindo aos usuários maior integralidade e resolutividades da atenção à saúde (BRASIL, 2018).

Habimorad (2015) destaca que para ampliação citada acima se faz necessário a formação profissional em PIC para SUS. Nota-se dificuldades no registro de informações sobre as PIC, relacionados ao baixo conhecimento de profissionais e gestores para o seu exercício. Recomendando a existência de normativas para a oferta dessas práticas na escola; quanto à capacitação dos Professores de Educação física e seu interesse na implementação dessas práticas no contexto escolar, como também dos gestores, bem como as orientações e o espaço que a escola oferta para a realização dessas atividades, são demandas que precisamos olhar com atenção, se tivermos a consciência do quão essa Política pode mudar as dinâmicas do território escolar.

Diante do exposto, essa pesquisa buscou realizar uma análise situacional das Práticas integrativas complementares de saúde no ambiente escolar na região de Maracanaú, visto que a escola é uma área privilegiada deste encontro entre a Educação e saúde, buscamos analisar as PIC no contexto escolar do município sob a perspectiva do Professor de Educação Física. 
Esperou-se alcançar, mediante esta proposta de pesquisa a compreensão quanto às possibilidades de inserção das PIC na Escola no Município de Maracanaú por meio da atuação do professor de Educação Física. Foi também proposta a evidenciação das Práticas Integrativas e Complementares como estratégicas de uma política pública de saúde para atuação desses professores.

Assim, como possíveis contribuições, espera-se que esta pesquisa possa estimular os professores de Educação Física a buscarem qualificação e aperfeiçoamento com as PIC no contexto escolar, ampliando os espaços de Educação e desenvolvimento das crianças e dos jovens em relação às atividades físicas e a prática do esporte, tendo em vista os reflexos dessa integralização no desenvolvimento integral desses sujeitos.

\section{Objetivo}

Analisar as possibilidades de inserção das Práticas Integrativas e Complementares no contexto escolar do município de Maracanaú sob a perspectiva do Professor de Educação Física.

\section{Método}

Para a composição do método, foi realizada uma pesquisa do tipo qualitativa, na qual, a pesquisadora levantou indagações que pôde conduzir no desenho do campo analítico da perspectiva dos Professores de Educação Física Escolar quanto ao funcionamento da engrenagem que articula a política das práticas integrativa e complementares e o PSE como elementos integrantes do conjunto pedagógico que transversaliza atuação do professor de Educação Física com crianças e jovens na escola. Conforme foi justificado, esses questionamentos foram levantados durante a formação da pesquisadora no curso de pós-graduação em Educação Física escolar na Instituição Universidade Estadual do Ceará.

A pergunta norteadora desta pesquisa é representada pelas seguintes questões: Qual a perspectiva dos professores da Educação Física escolar quanto à 
incorporação das práticas integrativas e complementares nas suas estratégias pedagógicas com crianças e jovens escolares? O que possibilita o engajamento, a capacidade de articulação dos eixos da política da saúde na Educação de acordo com a lente desses professores? Que elementos são facilitadores e dificultadores na disposição desses professores para aderir a essas propostas na escola?

Essa pesquisa visou realizar uma análise situacional como uma alternativa metodológica para abordar problemas de forma situada. A partir da análise situacional foi possível estabelecer propostas para resolução dos problemas tratados na análise de Clarke (2015).

O delineamento analítico de uma situação permitiu a identificação dos percursos de amostragem teórica que sustentaram esse delineamento e são expressos através de agrupamento de percepções docentes com os quais é possível figurar o processo no qual emergiram a interação dos pesquisadores com um problema específico, de acordo com Clarke (2015). No caso desta pesquisa, o problema se retratou pela incorporação das Práticas Integrativa Complementares no contexto Escolar por meio do protagonismo do professor de Educação Física.

Os agrupamentos de percepções docentes foram confeccionados a partir do roteiro de entrevista estruturado a respeito da percepção dos professores de Educação física no contexto escolar, quanto à integração das PIC no ensino da Educação Física no município de Maracanaú, localizado no estado do Ceará. As entrevistas foram analisadas de forma a estabelecer uma engrenagem do movimento que destacou o interesse, a motivação, os saberes e as ações docentes desses profissionais no sentido de viabilizar o uso desses recursos na realidade da formação dos estudantes escolares.

O agrupamento de percepções docentes foi escolhido como prioridade nesta pesquisa por permitir o desenho da Política Nacional de Práticas Integrativas e complementares na atuação do professor de Educação física na escola em âmbito local, como um terreno analítico, no qual existe uma perspectiva de articulação do eixo saúde e Educação, do desenvolvimento pessoal do jovem, da melhoria da qualidade do ensino, bem como da integração dos recursos pedagógicos aos professores, como práticas sugestivas para atender efetivamente as dimensões que envolvem o desenvolvimento humano pleno dos jovens, que tem relação com o cognitivo, 
espiritual, social, emocional, familiar, físico e mental, correspondendo a um ser integral e que, portanto, necessitam de um profissional que tenha a visão da formação integral.

Como variáveis de controle, não serão considerados a previsão do plano pedagógico para fins de comparação. Também não será inserida a política municipal de promoção da saúde na escola, nem os aspectos determinantes de qualidade de vida para discussão dos resultados.

O estudo foi desenvolvido nas escolas da rede municipal da região de Maracanaú-CE, cidade da região metropolitana de Fortaleza, localizada a $24 \mathrm{~km}$ do centro da cidade, hoje com 35 anos de emancipação considerada o maior polo industrial do estado e conhecida como a maior cidade dormitório do Ceará, ocupa o $5^{\circ}$ lugar na posição do ranking estadual de Índice de Desenvolvimento Municipal, segundo dados do Instituto de Pesquisa e Estratégia Econômica do Ceará (2014), de acordo com o site da prefeitura municipal em 2018.

A escolha do município foi feita em razão do trabalho da pesquisadora no campo como professora de Educação Física Escolar na iniciativa privada, fato que aproxima da realidade local, principalmente no tema que se deseja pesquisar. Embora a atuação da pesquisadora seja inserida no âmbito da Educação privada, existe o interesse de consolidar uma política pública no município, o que justifica a escolha pelo território do ensino público que assume o compromisso de implementar as diretrizes e as políticas de melhoria do ensino na Educação básica. No tocante à Práticas Integrativas Complementares (PNPIC), O Programa Saúde na Escola (PSE), objetiva consolidar as práticas corporais integrativas no sentindo de integralizá-las ao ensino da Educação Física, como ações de saúde que fazem parte do Eixo Atividade Física na Escola do PSE.

Assim, foram listadas 45 escolas que possuem convênio com o PSE, posteriormente selecionadas somente as escolas que apresentava professores de Educação Física, visto que a maioria eram creches ou escolas com anos iniciais (Fundamental I) que não apresentavam professores da área no corpo docente. No total foram 16 escolas contempladas com a pesquisa, tendo o número de 13 professores entrevistados por algumas escolas apresentarem o mesmo professor como docente, 
deste modo a pesquisa possibilitou uma análise de similaridade de discurso com os professores de Educação Física que atuam em escolas conveniadas ao PSE.

Foram professores de Educação Física, de ambos os sexos, pertencentes às escolas onde a pesquisa foi realizada, que tiveram vínculo concursado ou seletista. De acordo com levantamento prévio na Secretaria de Educação do Município, estimamse a participação de 40 professores de Educação Física vinculados às escolas selecionadas para a pesquisa.

Como critérios de inclusão, o professor deve ter um período superior a um ano de docência na Escola pesquisada, esteja trabalhando durante a realização da pesquisa, tenha disponibilidade para responder ao Questionário e assine o Termo de Consentimento Livre e Esclarecido. Não estabelecemos restrições com qualquer nível de grau (graduado, especialista, mestre e doutor).

Os critérios de exclusão estabelecidos foram: Período de atuação inferior a um ano na escola pesquisada, que se recuse a participar da entrevista, que esteja afastado, de licença, de férias ou outras formas de ausência do contexto da docência.

A pesquisadora aplicou um Roteiro de Entrevista Estruturada com indagações aos professores de Educação Física sobre: o seu conhecimento quanto às práticas integrativas e complementares e sistemas complexos para promoção da saúde da criança e do adolescente no contexto escolar e como recursos para dar suporte no desenvolvimento das atividades físicas e dos esportes; sobre o interesse dos Professores de Educação Física em implementar as práticas no contexto escolar; em relação ao seu nível de capacitação para atuar com as PIC nas escolas do município de Maracanaú; no tocante a reconhecer o espaço curricular que a Escola oferece para a realização dessas práticas ministradas pelo professor de Educação Física.

A coleta de dados iniciou após a aprovação do Comitê de Ética e Pesquisa da Universidade Estadual do Ceará (UECE) e, após assinatura e explicação do Termo de Consentimento Livre e Esclarecido (TCLE) para os participantes.

Ao pensar na técnica de coleta de dados pretendida, consideramos a fala de Gil (2008), que diz: a entrevista é uma técnica de coleta de dados onde o investigador frente ao investigado lhe formula perguntas, com o objetivo de obtenção dos dados que interessam investigar, adotada como uma técnica fundamental na investigação de 
variados campos de pesquisa. Método no qual o pesquisador terá um contato mais direto com os entrevistados, no sentido de obtenção de informações acerca do que as pessoas sabem, bem como das suas explicações.

Considerada como uma das mais flexíveis técnicas de coletas de dados de acordo com seu nível de estruturação, o método que será escolhido para este projeto de pesquisa é a entrevista estruturada, desenvolvida a partir de perguntas fixas, cuja ordem e redação permanecem invariáveis para todos os entrevistados, possibilitando o tratamento quantitativo dos dados devido a sua rapidez (GIL 2008).

A entrevista foi estruturada e definida como um modelo de entrevista em que o pesquisador se baseia em um roteiro elaborado previamente estabelecido, onde as perguntas direcionadas ao entrevistado são formuladas antecipadamente. Decorrente por um formulário organizado, a entrevista estruturada é realizada prioritariamente com pessoas escolhidas diante de um planejamento prévio (MARCONI; LAKATOS, 2003).

Os instrumentos utilizados para a realização da coleta da pesquisa foram: Uma entrevista estruturada; checklist contendo as 29 práticas integrativas e complementares, contempladas na política nacional de práticas integrativas complementares; checklist das práticas integrativas e complementares que utiliza na escola; Informações gerais do PSE que tratou da linha de ação: promoção das práticas corporais, Atividade física e Lazer do PSE, como parte integrante do componente II, considerado uma ação optativa, que objetivou oferecer práticas corporais, atividade física e lazer relacionados à realidade da comunidade incluída no cotidiano escolar.

A entrevista estruturada constou de perguntas sintonizadas com os objetivos propostos, para qual cada professor convidado com abordagem direta e pessoal que responderam as questões levantadas. O cheklist foi realizado como apoio para observação e condução das questões consonantes aos aspectos que permeiam a percepção desse professor quanto as PIC como recursos pedagógicos na Educação Física no contexto escolar.

Para a realização da análise dos dados, o conteúdo utilizado inicialmente para aproximar os aspectos relacionados à percepção dos professores sobre as PIC e o engajamento dos docentes com essas práticas com crianças e jovens na escola, teve 
como base os questionários e articulação das respostas dos professores com as estratégias da PNPIC e PSE. Este primeiro recorte diz respeito ao saber, as intenções e motivações dos profissionais.

No segundo momento da análise, foram localizadas as ações desenvolvidas pelos professores que, de forma direta ou indireta, tiveram a finalidade de exaltar as recomendações da política e do programa dentro do território escolar engajando esse professor como promotor de saúde e facilitador do ensino aprendizagem com repercussão pleno do estudante. Para fazer a localização dessas respostas, serão utilizadas as palavras-chave: Práticas Integrativas e Complementares, Educação Física Escolar, Programa Saúde na Escola, Desenvolvimento Integral de Crianças e Jovens.

As entrevistas direcionadas pelas palavras-chave serviram como sementes para uma futura construção de hipótese e arcabouço teórico para a realização de intervenções e pesquisa-ação com essa temática. E assim possibilitaram a construção do agrupamento de percepções docentes a partir do que foi possível delinear o terreno analítico da situação da PNPIC na profissão de Professor de Educação Física na escola neste município específico.

A análise situacional mostrou-se flexível, abrangente e metodológica de forma que o próprio terreno analisado emergiu os resultados necessários, com isso possamos partir de um pressuposto e/ou uma hipótese para possíveis resoluções da problemática de implementação das PIC na escola, como campo de atuação pedagógica do Professor de Educação Física, de modo que seja capaz de transformar a realidade educacional desses contextos.

A pesquisa foi submetida ao Comitê de Ética e Pesquisa da Universidade Estadual do Ceará (CEP-UECE), respeitando os Preceitos Ético-Legais (autonomia, não maleficência, beneficência e justiça) recomendados na resolução $n^{\circ} 466 / 12$ sobre pesquisas envolvendo seres humanos do Conselho Nacional de Saúde (BRASIL, 2013).

A participação dos sujeitos foi de forma voluntária, sem vínculo de qualquer benefício ou vantagem. Foram esclarecidos os objetivos, metodologia e relevância do estudo. Ao aceitarem participar da pesquisa, foi solicitada a leitura e assinatura do Termo de Consentimento Livre e Esclarecido (TCL). Os participantes 
ficaram com uma via original do TCLE, devidamente assinado pela pesquisadora, e a outra via ficou em posse da pesquisadora.

As informações sobre os riscos e os esclarecimentos de eventuais dúvidas foram repassadas e também foram mantidas o direito em desistir ou interromper a participação do professor a qualquer momento sem prejuízos, através dos telefones disponibilizados ou pessoalmente.

Todos os dados obtidos durante o estudo serão guardados de forma confidenciais. Nenhuma informação envolvendo o nome do professor será fornecida a qualquer pessoa e nem será identificado pessoalmente em nenhum momento da pesquisa.

O material coletado ficou arquivado por período de coleta e salvos em computador. Tudo será destruído após cinco anos do término do estudo, conforme orientação da Resolução n ${ }^{\circ}$ 466/12 do Conselho Nacional de Saúde (BRASIL, 2013).

\section{Resultados e Discussão}

No que se refere às características dos professores entrevistados, foram Professores de Educação Física atuantes nas escolas do município de Maracanaú-CE que apresentava convênio com o Programa Saúde na Escola. A amostra foi composta por 13 professores de Educação Física, 8 do sexo masculino e 5 do sexo feminino, totalizando em 16 escolas comtempladas pela pesquisa dentro das normas de inclusão e exclusão tendo em vista que 3 professores entrevistado atuam em duas escolas.

Primeiramente, entendo que o processo de entrevista é composto de várias etapas e para dar início me senti receosa devido o assunto ser novo e desafiador aos

professores da área por apresentarem desconhecimento de sua política. Não sabia o que esperar, não sabia quais seriam as reações e respostas, e quais desafios teriam que enfrentar, mas consegui aplicar a entrevista.

De início encontrei muita dificuldade em localizar os professores das escolas listadas com convênio com o Programa Saúde na Escola, em seguida consegui um momento com eles, fiz todo o mapeamento (endereço, contatos de telefone e dias disponíveis), alguns foram necessários visitar mais de duas vezes, outros não consegui 
contato, outros não se disponibilizaram para a pesquisa. Nas entrevistas, o primeiro desafio foi a pergunta que abordava as PIC como sigla, porém após uma explicação prévia e exemplificada, iniciou-se uma conversa aberta e prazerosa. Alguns entrevistados queixaram-se da falta de tempo para responder a entrevista, em alguns momentos foi necessário aguardar uma maior disponibilidade, porém ao longo do processo toda a entrevista foi realizada.

Para a coleta e produção das informações, os participantes após assinarem o termo de consentimento livre e esclarecido, responderam a uma pergunta norteadora, condizente com o objetivo da pesquisa, e lhe foram apresentados o cheklist das 29 Práticas Integrativas Complementares em saúde presente na PNPIC na qual permitia aos indivíduos interagir livremente com o entrevistador.

Tais professores foram selecionados de acordo com os critérios para participação da entrevista considerando que suas escolas estivessem conveniadas com o PSE, contando também com suas disponibilidades para a participação no estudo. Para garantir o anonimato, os Professores foram denominados de plantas medicinais: Marcela, Colônia, Canela, Cidreira, Camomila, Hortelã e Boldo do Chile, Alecrim, Quebra Pedra, Babosa, Espinheira Santa e Alfazema, denominação esta escolhida pela pesquisadora que faz elo com a Fitoterapia, uma das práticas integrativas e complementares.

Dos entrevistados analisamos as falas que condizem com os objetivos propostos da pesquisa relacionados a inserção das PIC nas escolas de Maracanaú.

Quanto aos aspectos que interferem na inserção das PIC foram apontados pela primeira entrevistada: Marcela, 39 anos, Pós-graduada, com 9 anos de formação. Ela começou relatando atividades realizadas na escola de promoção a saúde de cunho informativo e de orientação. A professora fala que nem mesmo na pós-graduação teve contato com as PIC, porém considerando o assunto importante, mas complexo à realidade da comunidade escolar, apontando que as dificuldades de estrutura ou material poderiam prejudicar abordagem das PIC.

Não tive contato com as PICS e nunca apliquei. [...] Nem na pós-graduação tive contato, nenhum texto nenhuma base teórica sobre o assunto. Considero o assunto importante, mas é importante de acordo com a realidade da 
comunidade escolar, não adianta apresentar uma prática que necessite de algo (estrutura, material), e não colocar em prática, não sair do papel (Marcela).

Durante a entrevista indaguei à Professora sobre práticas alternativas simples que não requer de muitos recursos, e o discurso dela foi o seguinte:

São muitas atividades aqui apresentadas no checklist, acredito que algumas dessas poderiam sim serem feitas nas escolas, mas não todas. Percebe-se que tem práticas mais complexas, por outro lado algumas bem mais simples como a Meditação que no caso precisaria só de uma sala (Marcela).

Para finalizar, Marcela expõe a partir do seu conhecimento prévio que a inserção dessas práticas pode trazer benéficos como: ajudar na concentração, no autoconhecimento, apresentando fatores que interferem positivamente na condição física e mental do aluno.

O entrevistado Boldo do Chile de 30 anos, especialista com mais de 7 de formação, pontuou a falta de conhecimento sobre o assunto, ponto este existente em todas as falas dos 13 entrevistados quando apresentadas as PIC como política pública. Ele coloca como evidência o desconhecimento das PIC em seu conhecimento base e em todo o currículo que orienta os professores de Educação Física do Município.

Na graduação a gente não vê esse tipo de conteúdo, e ali é nossa base. [...]
também não foi colocado dentro do que se pede pelo município em relação à
Educação Física, nenhum desses 29 itens apresentado na checklist foi
orientado a ser trabalhado dentro da escola, na aula de Educação Física
especificamente. Como são ações que não estariam dentro dos conhecimentos
básicos que permeiam a Educação física, para ser inserido com os professores
da área, deveríamos antes ter todo subsídio desde a gradação até formações e
capacitações (Boldo do Chile).

Quanto às normativas para a oferta dessas PICS, os entrevistados a seguir apresentam falas semelhantes quanto ao interesse em inseri-las na área escolar como também apresentaram experiências de contato mesmo desconhecendo sua política.

Colônia de 31 anos, especialista em Educação Física escolar com 9 anos de formação, apresenta certa aproximação com algumas práticas; ela já fez um curso de extensão em biodança e já realizou algumas práticas na sua rotina pessoal como reiki, Meditação, auricunputura. 
As PICS poderiam sim ser inseridas nas escolas, como mais uma forma de conhecer e entender seu corpo, adquirindo maior consciência corporal, despertando o autoconhecimento e seus limites. [...] esse saber é importante. É mais um conhecimento, trazê-lo para a escola seria ampliá-lo, mas para isso precisamos de mais investimento em nossas formações (Colônia).

Camomila de 33 anos, especialista e com 9 anos de formação, também demostra aproximação com o conteúdo após a minha apresentação sobre o assunto, a professora relata que já pensou em preparar uma aula diferente com algumas das práticas existentes no checklist que apresentei, mesmo confessando que não tinha nenhum conhecimento da normatização dessas práticas com a política nacional de práticas integrativas complementares.

É uma outra forma de conhecimento que vai além das "práticas esportivas",
[...] porque aqui na escola já era evidenciada as práticas esportivas e na
proposta de apresentar um conhecimento a mais venho apresentando outros
conteúdos como práticas diferenciadas. [...] pretendendo já usar a prática de
yoga, e contemplando o conteúdo da Dança os meus alunos irão apresentar no
seminário o que seria a Dança Circular, mas falo dessas práticas não no
sentindo de que estaria trabalhando as PICS até porque não conhecia, mas
agora que eu sei já posso inseri-las. [...] O professor pode contribuir sim para
a inserção das PICS nas escolas, até porque somos da área da saúde, nós
também devemos estar disseminando o cuidado de si, do corpo e estimulando
essa consciência de cuidado com os alunos (Camomila).

Camomila finaliza falando do receio de propor essas práticas e não ter muita acessibilidade, não ter aceitação, porém mostra que seria um desafio a ser enfrentado com estratégias apresentando o assunto de forma ilustrada e construindo um ambiente de aceitação entre eles.

Hortelã, graduado de 38 anos e formado há 5 anos, logo no início mostrou por meio de exemplos a sua proximidade com as práticas de meditação e yoga, o mesmo conta que esse conhecimento teve na faculdade, mas não foi na grade curricular da graduação e sim em cursos extras e de extensão.

Adquiri esses conhecimentos por meio de cursos de extensão e estudos individuais, no ano de 2013 trabalhei com a meditação escolar para a concentração dos alunos, apliquei em todas as turmas e vi uma melhora muito grande. [...] Já tinha esse feeling por essa prática e os benefícios que ela poderia trazer. Vejo que existe uma relação das PICS e a Ed física no sentindo de fazer o indivíduo se perceber em prol da sua saúde, todavia essa comunhão com Ed Física, enfrenta dificuldade por ser um conhecimento amplo, 
conhecimento este que a graduação não contempla. [...] Teria que valorizar a graduação, aumentar mais o tempo de graduação e inseri-lo (Hortelã).

\begin{abstract}
Para finalizar, ele mesmo expõe sua opinião de achar que esse conhecimento na escola seria muito aprofundado e exigiria do professor um conhecimento verticalizado.
\end{abstract}

A nossa graduação não deu conta disso, teria que ser a nível de especialização, não daria para abordar como a gente faz com as grades curriculares, [...] teria que ter um professor para cada prática assim como tem de Ed. Física teria que ter um professor de reiki e de yoga (Hortelã).

Canela, de 44 anos, especialista em Educação Física escolar e 12 de formação, discursa em toda sua entrevista aberturas para sua inserção nas escolas.

Não conhecia por esse nome, mas conheço algumas dessas práticas, algumas
tentei fazer até algo parecido como yoga em uma atividade de alongamento,
essa questão de respiração utilizada dentro de uma atividade. [...]acredito que
deve sim ser implantado, tem tudo para acontecer, são atividades que
promovem a consciência corporal e que acrescentam no autoconhecimento,
autopercepção, na questão de se perceber e perceber o outro. [...] Essas
atividades conseguem favorecer a compreensão dos seus limites e percepção
de mundo. [...] Eu acredito que exista possibilidade de implementação, pois
as práticas têm uma conexão com a cultura corporal, e na busca de diversificar
as nossas, ações as PICS seriam mais uma possibilidade de atuação
profissional e intervenção pedagógica na sala de aula para nós, professores de
Ed. Física (Canela).

Ao longo do seu discurso foram pontuados aspectos de cuidado com a inserção das práticas nas escolas:

Temos que ter muito cuidado com a sua implantação no que se refere atenção dos alunos, devem ser ministradas práticas que tenha a ver com a realidade escolar e com aceitação dos alunos, acredito que a biodança, dança circular, yoga, meditação, sejam boas opções, tendo em vista que outras práticas seriam necessárias mais recursos, como também um maior autoconhecimento levando em considerações práticas que envolvem contato pessoal (Canela).

Canela ainda relatou que devemos ter um olhar atencioso às questões de turmas, como brincadeiras, distorção do sentido das atividades, pois na condução dessas atividades poderá existir práticas direcionadas ao contato físico, podendo ser realizadas em duplas e exigindo um pouco mais de maturidade dos alunos. $\mathrm{O}$ 
entrevistado acrescenta que a turma tem que estar bem ciente da proposta das práticas e que essas aulas necessitam de maior preparação do professor associada com um bom domínio de turma, para que evite qualquer divergência referente a proposta das PIC como também situações constrangedoras.

O entrevistado Quebra Pedra, de 31 anos, graduado há 9 anos, discorre bem sobre os aspectos que podem melhor preparar os professores para atuação com as PIC no ambiente escolar. Ele afirma que os professores de Educação Física seriam essenciais para práticas integrativas serem inseridas nas escolas, isso porque os professores da área têm em específico o conhecimento do corpo em promoção da saúde.

Eu vejo as práticas integrativas complementares em saúde mais complexas
comparadas às práticas corporais que nós temos e trabalhamos, e aí me remete
a formação acadêmica que deixa a desejar, o que seria necessário uma
formaça direcionada, orientada para que seja trabalhado de forma eficaz e
não fazer por fazer. [...] o município deveria sim investir e colocar essas
práticas nas escolas [...] Dentro das nossas formações mensais, poderia se abrir
espaço para termos conhecimento e trabalharmos essas práticas e nós sermos
divulgadores através dos nossos trabalhos (Quebra Pedra).

Percebe-se que a formação complementar seria um importante fator para inserção das PIC nas escolas, este mesmo fator foi citado por vários entrevistados quando o entrevistador pergunta qual a iniciativa a ser tomada pelo município para que as PIC de fato possam ser inseridas nas escolas.

[...] a prefeitura poderia contribuir com esse tema junto as nossas formações onde cada professor dentro de sua realidade poderia aplicar o que seria mais viável. A prefeitura também pode colaborar através de projetos inserindo um profissional gabaritado para que fosse realizada essa inclusão dentro das escolas através de palestras, projetos e grupos com o nosso apoio (Professores de Educação Física) (Marcela).

[...] Uma forma que poderia ser nas próprias formações, temos aqui no município um dia por mês da formação onde reúne todos professores, então seria um meio de divulgar as PICS e trabalhar com todos professores juntos (Camomila).

Seria ideal termos formação contínua, e apresentar as PICS de acordo com necessidade de cada escola (Alfazema).

O professor só pode contribuir se ele for formado para isso. (Cidreira). 
De fato, seria com investimento e formação (Arnica).

O município poderia incentivar abordando em nossas formações (Babosa).

O município poderia incentivar nós professores a fazermos capacitação na área, sabendo da importância de cada professor se capacitar e buscar mais conhecimento (Espinheira Santa).

Os resultados obtidos foram agrupados em categorias temáticas de acordo com aspectos apresentados nos discursos dos professores durante a entrevista. Emergiram então duas categorias. São elas: categoria 1 - Saber, Intenções e Motivações dos Professores de Educação Física em relação à inserção das Práticas Integrativas e Complementares em saúde como ação de Promoção de Saúde na Escola. Categoria2. Ações desenvolvidas pelos professores que de forma direta ou indireta tenham a finalidade de exaltar as recomendações da Política Nacional de Práticas Integrativas e Complementares na Escola e do Programa Saúde na Escola.

\section{Saber, intenções e motivações dos professores de Educação Física em relação à inserção das práticas integrativas e complementares em saúde como ação de promoção de saúde na Escola}

Esta categoria revelou através de discursos, a existência de aspectos associados ao saber, intenções e motivações dos professores entrevistados no que interferem na relação de inserção das PIC no âmbito escolar como uma efetiva proposta de ação em promoção da saúde. Vimos nas narrativas dos professores, pouco conhecimento sobre PICS, o contato poderia existir de forma indireta com algumas práticas, mas sem conhecimento específico ou relacionado à Política Nacional de Práticas Integrativas Complementares (PNPIC).

Sabemos que a institucionalização das Práticas Integrativas e Complementares no Sistema Único de Saúde (SUS) pela PNPIC conseguiu aumentar o acesso a produtos e serviços, como também trouxe propostas de unir saberes e práticas nas diversas áreas do conhecimento para desenvolvimento de projetos humanizados, integrais e transdisciplinares (BRASIL, 2009). Mas apesar desse interesse em pesquisas e o crescente uso das PIC nos últimos anos, percebemos a falta 
de artigos e estudos que potencialize o conhecimento dessas práticas, além da ausência de formação de profissionais qualificados para realizá-las (AZEVEDO; PELICIONI, 2012).

Segundo Ruela (2018), o desconhecimento da PNPIC e de suas práticas elencadas na política dificulta adesão de profissionais e serviços para suas ofertas. Portanto a formação profissional seria um importante abertura para implementação das PIC.

Após uma explicação sobre o que seria a PNPIC e apresentadas as 29 PIC existente na política, percebemos o interesse dos professores entrevistados em conhecer e introduzi-la em suas aulas como proposta pedagógica que promova um conhecimento a mais aos alunos e ajude-os na sua formação crítica e autônoma que emerge a partir da construção e conscientização dos conhecimentos sobre o seu próprio corpo e da saúde.

Aguiar e Dias (2017) falam que é necessário despertar o corpo na escola, fazê-los experimentar sensações corporais de introspecção e que auxiliem para uma rotina com maior qualidade de vida, estimulando as práticas corporais com o intuito de promover o autoconhecimento e associá-lo à saúde integrativa e complementar.

No âmbito escolar, as Práticas Integrativas e Complementares em Saúde constituem-se em uma ferramenta de integração interpessoal, promovendo a cooperação, formação de uma cultura de respeito, responsabilidade e tolerância (RUELA et al., 2018).

Com base nas possibilidades de inserção das PIC nas escolas, os professores entrevistados destacaram fatores que influenciariam, de forma positiva e negativa na sua inserção.

Fatores positivos: Maior diversidade de conhecimento em promoção da saúde para os alunos; os inúmeros benefícios que as práticas trazem em promoção e manutenção da saúde além do envolvimento da comunidade escolar em conhecer e experimentar essas práticas.

Fatores negativos: complexidade das práticas comparadas com as existentes na grade curricular, ausência destas práticas na grade curricular na formação acadêmica dos professores, dificuldade de aceitação, dificuldades estruturais para 
realizar as práticas, dificuldades em recursos básicos e específicos que cada prática tem com uso de técnicas, o possível prejuízo ao tempo de planejamento dos conteúdos exigido na base, a falta de envolvimento e conhecimento da gestão escolar sobre as PIC.

Considerando esses fatores, podemos concordar com Ruela et al. (2018), que as PIC são consideradas como uma importante estratégia de assistência à saúde, como também uma via de cuidado e integralidade do ser humano. Porém, elas enfrentam barreiras na sua inserção, presentes até mesmo na atenção básica, o que seria sua porta de entrada.

Apresentá-la no contexto escolar também seria um desafio constante, mesmo sabendo que tais práticas não necessitam de recursos tecnológicos, as dificuldades acessos aparecem e podem estar ligadas a falta de conhecimento dos profissionais sobre o seu uso e sua importância, indicando uma relação à falta de habilidades adequadas para indicar ou aplicá-las (RUELA et al., 2018).

Ações desenvolvidas pelos professores que, de forma direta ou indireta, tenham a finalidade de exaltar as recomendações da Política Nacional de Práticas Integrativas e Complementares na Escola e do Programa Saúde na Escola

Esta categoria mostra que em sua maioria os professores reconhecem a importância das Práticas integrativas, porém por falta de conhecimento específico, eles apresentam dificuldade em inseri-las em suas aulas, mesmo assim foi possível observar na fala de professores ações desenvolvidas nas escolas que estão intimamente conectadas ao cuidado, autoconhecimento e na formação integral dos alunos (corpo, mente e espírito).

As três práticas integrativas complementares: yoga, meditação e dança circular ganharam destaque nas aulas de dois professores que citaram em suas entrevistas como ações desenvolvidas. Os professores destacaram que utilizaram uma abordagem mais ampla, nada específica, todavia foi possível reconhecer vários benefícios que as práticas auxiliaram no momento de aula, como: maior concentração, reflexão e o despertar dos alunos para uma pesquisa mais aprofundada do conteúdo. 
Muitos artigos encontrados na literatura e reportagens abordam as PIC como uma via direta de assistência à saúde, cuidado e integralidade do ser humano. Isso justifica as várias articulações encontradas em escolas por diversos estados, que fortalece e expande a inserção das Práticas Integrativas Complementares em Saúde em escolas.

No Centro Educacional Gesner Teixeira, localizado em Gama-DF, em 2019, introduziram as práticas integrativas em saúde como projeto piloto, com proposta de oferecer práticas de terapia comunitária integrativa, automassagem, meditação e reiki, voltados para a prevenção de doenças e promoção de saúde. Conforme relato dos gestores das escolas, os grupos de 24 estudantes adolescentes obtiveram uma melhora significativa no desempenho escolar, com esse projeto a escola foi premiada em $1^{\mathrm{o}}$ lugar pela controladoria do Distrito Federal, recebendo investimento financeiro para a iniciativa e levando o projeto a mais sete escolas que fazem parte da coordenação regional de ensino de gama.

Em Santos SP, as práticas são realizadas voluntariamente pelo grupo Geisi há um ano, em parcerias com as secretarias de saúde e de Educação nas escolas Maria Patrícia (Valongo), Leonor Mendes e Clovis Bandeiras Brasil. A ação é baseada no modelo de atenção integral (mente, corpo e espírito), com a proposta de envolver a comunidade para que possa conhecer e experimentar estas atividades (PREFEITURA DE SANTOS, 2018).

São exemplos como esses que incitam e nos levam a questionar a adesão ou não a esse saber como núcleo da formação básica do Professor de Educação Física. Se trabalhamos, como Professores de Educação Física, pelo melhor desempenho estudantil, devemos ressaltar que este indicador cresce simultaneamente com o desenvolvimento de nossos estudantes. Por isso, agregar práticas, ações e estratégias no planejamento da promoção de saúde implica uma contínua busca por Políticas que afirmem essa intercessão entre educação e a saúde no âmbito da escola.

Assim, estabelecendo uma avaliação situacional, conhecendo os saberes e práticas e as experiências vividas no corpo docente, a promoção da saúde na escola poderá se tornar um campo de potências para inserção das práticas integrativas e complementares em saúde. 


\section{Considerações Finais}

A presente pesquisa possibilitou analisar e descrever aspectos que interferem na inserção das PIC no contexto escolar como a falta de conhecimento sobre as PIC; a falta de articulação entre os programas de saúde na escola e os professores de Ed física, no que apresentou um certo despreparo dos professores em atuar com as Práticas Integrativas Complementares no município de Maracanaú. Esses aspectos foram confirmados nas falas dos professores entrevistados que mostraram falta de conhecimento sobre as PIC com relação às aberturas que as Escolas Públicas do município de Maracanaú oferecem para sua implantação. Foi reconhecido que esta ausência e desde a grade curricular dos Cursos de Educação Física, até suas formações e orientações pedagógicas, o que torna o conteúdo distante de sua prática profissional, mostrando que a falta de políticas públicas e legislação atuante prejudica a existências de possíveis profissionais especializados e/ou capacitados para atuar com as PIC.

Quanto ao conhecimento dos professores sobre as PIC e sistemas complexos para promoção da saúde de crianças e adolescentes no contexto escolar, identificamos após apresentação das 29 PIC citadas nessa pesquisa o reconhecimento de algumas dessas práticas pelos professores, como também a sua importância no ambiente escolar associada aos benefícios que elas contribuem para a formação integral dos alunos. Tendo em vista que, algumas dessas práticas como: yoga, meditação e dança circular já estiveram presentes nas aulas de Educação Física desses professores, mesmo desconhecendo a sigla e suas normativas

Também foi possível conhecer o interesse dos professores em implementar as PIC no contexto escolar por meio do reconhecimento em assumir a responsabilidade de atuar com as PIC através de ações e atividades que estão intimamente conectadas ao conhecimento de saúde e educação que o professor de educação física já tem, o que reafirma o documento do PSE 2007 em pontuar as PIC, como práticas corporais de domínio/propriedade dos profissionais de Educação Física.

De forma geral, foi possível considerar que conseguimos analisar as possibilidades de inserção das Práticas Integrativas e Complementares no contexto escolar do município de Maracanaú sob a perspectiva do Professor de Educação Física. 
Considerando a existência de normativas para a oferta dessas práticas na escola; a existência de Professores de Educação Física especializados e/ou capacitados para atuar com as Práticas Integrativas Complementares no município de Maracanaú.

Especificamente, atendendo aos objetivos propostos, esta pesquisa viabilizou a compreensão de que a fragilidade de incentivo ou disponibilidade da construção desse conhecimento sobre as PIC na formação base dos Professores de Educação Física se torna um aspecto que distancia as práticas integrativas de sua realidade escolar. No entanto, foi reconhecido que algumas das PIC já foram trabalhadas de forma indireta pelos professores, permitindo assim a compreensão de sua importância no ambiente escolar, como também recurso pedagógico para formação integral dos alunos, que por sua vez foi demostrado interesse dos professores em implementar as PIC no contexto escolar, através de ações e atividades que estão conectadas a política nacional de práticas integrativas e saúde e com o planejamento das aulas.

Como síntese, percebe-se que as práticas integrativas complementares em saúde no contexto escolar são um desafio a ser alcançado com foco na atuação dos professores de Educação Física, os quais são profissionais de saúde importantes na escola para a implantação das PIC; e essa importância pode ser melhor consolidada com pesquisas de intervenção e de impacto.

Diante dos resultados alcançados, consideramos necessário apontar sugestões que podem ser eficazes na inserção das PIC nas escolas de Maracanaú. Dessa forma foram destacados: maior atenção da Prefeitura de Maracanaú em investir nas formações continuadas com capacitação, especializações e cursos que sirvam de suporte e conhecimento para atuação dos seus professores.

É inegável, pelo apreendido nos resultados, que a participação da Universidade, dos Conselhos e Novas Diretrizes Curriculares podem interferir no processo de valorização desse saber na matriz curricular dos Cursos de Educação Física. 


\section{Referências}

AGUIAR, Milena de Oliveira; DIAS, Maria Aparecida. A educação física escolar: primeiro contato com as práticas integrativas e complementares. In: CONGRESSO INTERNACIONAL DE PRÁTICAS INTEGRATIVAS E COMPLEMENTARES EM SAÚDE, 1., 2017. Rio de Janeiro. Anais [...]. Campina Grande: Realize Eventos e Editora, 2017.

AZEVEDO, Elaine de; PELICIONI, Maria Cecília Focesi. Práticas integrativas e complementares de desafios para a Educação. Trabalho, Educação e Saúde, Rio de Janeiro, v. 9, n.3, p. 361-378, nov. 2011/fev. 2012.

BRASIL. Lei no 9.394/06, de 20 de dezembro de 1996. Estabelece as diretrizes e bases da educação nacional. Diário Oficial [da] República Federativa do Brasil: seção 1, Brasília, DF, 23 dez. 1996.

BRASIL. Ministério da Educação. Parâmetros curriculares nacionais para o ensino fundamental. Brasília, DF: Ministério da Educação, 1997.

BRASIL. Ministério da Educação. Programa Saúde na Escola: informações gerais. Brasília, DF: Ministério da Educação, 2012. Disponível em:

http://portal.saude.gov.br/portal/saude/Gestor/visualizar_texto.cfm?idtxt=38070. Acesso em: 20 jul. 2018.

BRASIL. Ministério da Saúde. Glossário temático: práticas integrativas e complementares em saúde. Brasília, DF: Ministério da Saúde, 2018.

BRASIL. Ministério da Saúde. Portaria n ${ }^{\circ}$ 971, de 3 de maio de 2006. Aprova a Política Nacional de Práticas Integrativas e Complementares (PNPIC) no Sistema Único de Saúde. Brasília, DF: Ministério da Saúde, 2006. Disponível em: https://www.cff.org.br/userfiles/38\%20\%20BRASIL_\%20MINIST\%C3\%89RIO\%20DA\%20SA\%C3\%9ADE_\%20Portaria \%20n \%C2\%BA\%20971,\%20de\%2003\%20de\%20maio\%20de\%202006_.pdf. Acesso em: 7 set. 2021.

BRASIL. Ministério da Saúde. Portaria n 687, de 30 de março de 2006. Aprova a Política Nacional de Promoção da Saúde (PNPS). Brasília, DF: Ministério da Saúde, 2006. Disponível em: https://bvsms.saude.gov.br/bvs/saudelegis/gm/2006/prt0687_30_03_2006.html. Acesso em: 7 set. 2021. 
BRASIL. Ministério da Saúde. Secretaria de Atenção à Saúde. Política Nacional de Práticas Integrativas e Complementares no SUS: atitude de ampliação de acesso. 2. ed. Brasília, DF: Ministério da Saúde, 2018.

BRASIL. Ministério da Saúde. Secretaria de Atenção à Saúde. Relatório do I Seminário Internacional de Práticas Integrativas e Complementares em Saúde: PNPIC. Brasília, DF: Ministério da Saúde, 2009. Disponível em: http://189.28.128.100/dab/docs/geral/relatorio_1o_sem_pnpic.pdf. Acesso em: 24 set. 2021.

BRASIL. Resolução $\mathrm{n}^{\circ}$ 466, de 12 de dezembro de 2012. Diretrizes e Normas Regulamentadoras de Pesquisas Envolvendo Seres Humanos. Diário Oficial da União: seção 1, Brasília, DF, 13 jun. 2013. Disponível em: https://www.inca.gov.br/publicacoes/legislacao/resolucao-cns-466\%2012\#: :text=Aprova $\% 20$ as $\%$ 20diretrizes $\% 20 \mathrm{e} \%$ 20normas,revoga $\% 20$ as $\% 20$ Resolu \%C3\%20\%A7\%C3\%B5es\%20CNS\%20nos. Acesso em: 19 jul. 2021.

CLARKE, Adele E. Situational analysis: grounded theory after the postmo-dern turn. California: Sage, 2005.

GIL, Antonio Carlos. Métodos e técnicas de pesquisa social. 6. ed. São Paulo: Atlas, 2008. 200 p.

HABIMORAD, Pedro Henrique Leonetti. Práticas integrativas e complementares no SUS: revisão integrativa. 2015. 88 f. Dissertação (Mestrado em Medicina) Universidade Estadual Paulista Júlio de Mesquita Filho, Botucatu, 2015. Disponível em: http://hdl.handle.net/11449/139384. Acesso em: 20 jul. 2018.

INSTITUTO DE PESQUISA E ESTRATÉGIA ECONÔMICA DO CEARÁ. Índice de Desenvolvimento Municipal (IDM) Ceará. Fortaleza: Instituto de Pesquisa e Estratégia Econômica do Ceará, 2014. Disponível em:

https://www.ipece.ce.gov.br/wpcontent/uploads/sites/45/2014/05/IDM_2014.pdf. Acesso em: 24 set. 2021.

MARACANAÚ. Secretaria Municipal de Saúde. Consulta pública: base curricular de Maracanaú: aspectos gerais. Maracanaú: Secretaria Municipal de Saúde, 2018. Disponível em: http://www.maracanau.ce.gov.br/. Acesso em: 10 jul. 2018.

MARCONI, Marina de Andrade; LAKATOS, Eva Maria. Técnicas de pesquisa. São Paulo: Atlas, 2003.

OLIVEIRA, Heráclito Cardoso. Práticas Integrativas na escola pública: caminhos possíveis para um cotidiano de paz. [S.l.: s.n.], 2017. 
PREFEITURA DE SANTOS. Escolas aderem práticas integrativas de saúde. Santos: Prefeitura de Santos, 2018. Disponível em:

https://www.santos.sp.gov.br/?q=noticia/escolas-aderem-a-praticas-integrativasde-saude. Acesso em: 15 ago. 2019.

RUELA, Ludmila de Oliveira et al. Implementação, acesso e uso das práticas integrativas e complementares no Sistema Único de Saúde: revisão da literatura. Ciência \& Saúde Coletiva, v. 24, n. 11, p. 4239-4250, 2018. Disponível em: http://www.cienciaesaudecoletiva.com.br/artigos/implementacao-acesso-euso-das-praticas-integrativas-e-complementares-no-sistema-unico-de-saude-revisaoda-literatura/16793?id=16793. Acesso em: 10 jul. 2018. 


\section{3}

Educação Física escolare e drogas: Uma análise à luz da teoria marxista 


\title{
13 EDUCAÇÃO FÍSICA ESCOLAR E DROGAS: UMA ANÁLISE À LUZ DA TEORIA MARXISTA
}

\author{
Marcos Aurélio Silva de Sousa \\ Maria Eleni Henrique da Silva \\ Otávio Nogueira Balzano \\ Marcos Antônio Almeida Campos \\ Daniele Vasconcelos Fernandes Vieira \\ Sabrina Cavalcante Rodrigues
}

\section{Resumo}

A pesquisa tem como eixo central a investigação do fenômeno das drogas, sobretudo no âmbito da Educação e da Educação Física escolar. Entendemos que a Educação Física no âmbito escolar trata/tematiza os elementos da cultura corporal. Porém as drogas, enquanto fenômeno social configura-se como um conteúdo e tema transversal de nossas aulas. Objetivo: Investigar se a temática das drogas é abordada nas aulas de Educação Física de escolas públicas de Fortaleza-CE. Método: Utilizamos na pesquisa de campo como ferramentas de investigação dois questionários, sendo um específico para os professores e o segundo para seus alunos. Como resultados obtivemos que o conteúdo drogas é abordado nas aulas de Educação Física, porém de forma insuficiente, incipiente. Resultados: A análise dos dados apontou que a formação dos professores de Educação Física investigados, no que se refere ao conteúdo drogas, é precária. Obtivemos ainda que as drogas mais usadas pelos alunos são as drogas lícitas, como café, álcool, fármacos e cigarro e no que se refere às drogas ilícitas apareceu apenas à maconha. Conclusão: Entendemos ser o fenômeno das drogas algo bastante complexo, que não pode ser compreendido aparte da realidade como um todo, da Educação e da Educação Física e que o saber científico pode ajudar as pessoas, sobretudo nossos alunos a formarem opiniões críticas e coerentes acerca do tema e que podem também ajudar nas tomadas de decisões, autonomia sobre nossa saúde e nosso corpo.

Palavras-chave: Educação Física Escolar. Abuso de Drogas. Prevenção de Drogas. 


\section{Introdução}

Na sociedade contemporânea o uso de drogas é um tema que desperta polêmicas e controvérsias. Escohotado (1997, p. 31) afirma que "no mundo ocidental, raríssimas vezes são celebradas reuniões sem a abundante presença de bebidas alcoólicas, e certos ambientes contemporâneos acrescentam a cocaína".

Diversas políticas públicas, no Brasil, foram e estão sendo planejadas e implementadas para desenvolver ações no combate as drogas, que vão desde o intenso controle e fiscalização, a repressão e a criminalização. Como exemplo, podemos destacar a nova Lei Seca que conseguiu reduzir o número de pessoas que dirigem após beber. Porém, tais políticas públicas se mostram ineficientes no que diz respeito a como lhe dar com o uso de álcool na sociedade.

Apesar de o tema drogas ser alvo de diversas políticas públicas em nosso país e no mundo, assunto constante na mídia e na sociedade, ainda é um tema pouco discutido nas escolas e raramente abordado nas aulas de Educação Física. Partindo de pressupostos que consideram a sociedade dividida em classes antagônicas, deve ser papel da escola pública proporcionar aos educandos a formação de uma consciência de classe, através da reflexão crítica dos conteúdos da cultura corporal e também de temas transversais como as drogas, buscando estabelecer uma compreensão de totalidade, que permita aos alunos articular o tema drogas a questões como política, economia, trabalho, etc., possibilitando identificar e questionar as contradições da sociedade capitalista (SOARES et al., 1992). Como fenômenos, estas contradições se expressam em diversos âmbitos sociais que incluem a escola, a Educação Física e seus conteúdos, e também no âmbito das drogas que não podem ser entendidos descolados de outras esferas da sociedade.

Conforme os Parâmetros Curriculares Nacionais (PCN) o consumo de álcool, fumo e outras drogas ocorrem em idade muito precoce (BRASIL, 1997). A escola, principalmente através das aulas de Educação Física pode proporcionar aos educandos conhecimentos acerca das drogas que permita uma formação crítica sobre o tema e que possibilite a tomada de decisão e o desenvolvimento autônomo sobre o corpo e a saúde (DARIDO; SOUZA JÚNIOR, 2007). 
A prática de atividades que envolvem os elementos da cultura corporal (jogos, esportes, lutas, danças e ginástica, dentre outros) é considerada no senso comum como sinônimo de saúde e método eficaz no combate ao uso abusivo de drogas (BRASIL, 1998). Contudo, não se discute, por exemplo, como os atletas de alto rendimento são constantemente pressionados por empresários, treinadores, mídia, dentre outros, a fazerem uso de determinadas substâncias para melhorar seu rendimento. Não se questiona também o porquê de determinadas substâncias serem consumidas indiscriminadamente em diversos esportes, enquanto outras são proibidas. Ou seja, no senso comum é corriqueiro escutar que "o esporte afastava o indivíduo das drogas, mas não se abordava esse assunto na sua dimensão afetiva, psicológica, política, econômica ou sociocultural" (BRASIL, 1997, p. 58).

Portanto, os conteúdos acerca da temática das drogas não devem ser excluídos dos currículos escolares, pois abrangem discussões relacionadas ao cotidiano dos educandos (BRASIL, 1997). Para além do âmbito esportivo, as drogas estão presentes no dia a dia escolar como mostra pesquisa feita pelo Instituto Brasileiro de Geografia e Estatística (IBGE) publicada em 19/06/2013 na página da revista Época. Segundo Darido e Souza Júnior (2007), o consumo de drogas é um tema que pode ser trabalhado nas aulas de Educação Física, pois é uma preocupação comum na vida dos jovens, maior público das escolas.

Carneiro (2008, p. 65-66) afirma que

No que se refere às drogas, permanecem, contudo, os tabus, com algumas
substâncias proscritas e outras reguladas conforme diferentes graus de
permissividade (algumas com limitações de idade, de espaços e horários
permitidos ou não).

Ou seja, determinadas restrições são impostas a sociedade no que diz respeito ao controle estatal do uso de determinadas substâncias, em relação à idade como no caso do álcool que segundo o Estatuto da Criança e do Adolescente não pode ser vendido para menores de 18 anos, mas que é desrespeitado comumente, de espaço como no caso da escola não se pode fazer uso de drogas, dentre outras (BRASIL, 1990).

Durante meu percurso escolar não tive aulas que abordassem o tema drogas. Na Universidade também não foi diferente. Durante as aulas do curso de 
graduação em Educação Física do Instituto de Educação Física e Esportes (IEFES) da Universidade Federal do Ceará (UFC), por poucas vezes, tive a oportunidade de debater o tema e quando isso acontecia, era um debate que não respondia minhas dúvidas. Em regra, o que era apresentado nas aulas eram debates sobre doping, principalmente no âmbito dos esportes de competição, doping genético e uso de anabolizantes e esteroides. Contudo esses debates não sanavam meus questionamentos sobre o tema. Muito pelo contrário.

Embora não tenha tido uma formação acadêmica que me proporcionassem uma base para debater o fenômeno das drogas meu interesse a respeito do tema só crescia. Buscava estudar por conta própria e debatia com alguns amigos e colegas. Foi nos espaços do Movimento Estudantil que tive a oportunidade de conhecer pessoas que também se interessavam pelo assunto. Embora o tema não tenha sido abordado nos espaços formais do Movimento Estudantil que participei, foram nestes espaços que tive a oportunidade de discutir e acumular um pouco mais sobre o assunto. Nesses espaços tive a oportunidade de conhecer estudantes e professores que também se interessavam pelo tema. Comumente esses colegas me relatavam que não tinham muitos espaços para debater o tema. Geralmente, estudavam o assunto por conta própria e alertavam que há muitos preconceitos na abordagem do assunto, principalmente no meio acadêmico. Em uma destas conversas me indicaram um documentário chamado Cortina de Fumaça, que me despertou diversos questionamentos, principalmente no âmbito da educação física escolar.

O objetivo desta pesquisa é responder estas e outras questões que permeiam o fenômeno das drogas. Pretende conhecer, analisar e desconstruir diversos mitos que cercam o debate acerca do uso de drogas, trazendo elementos que possibilitem a formação de opiniões críticas, questionadoras e coerentes. Almeja também trazer contribuições para despertar a autonomia em nossos alunos para que estes possam assim, tomar decisões sobre seu corpo e sua saúde.

Para a Educação Física, espera-se trazer contribuições ao debate e despertar a atenção para o tema, que nos últimos anos vem ganhando repercussão na sociedade e na escola. Uma compreensão mais aprofundada pode proporcionar uma melhor orientação sobre o assunto e ajudar na prevenção de possíveis riscos quanto ao 
consumo abusivo de determinadas substâncias. Quem sabe assim, poderemos pensar em uma mudança de perspectiva no modo em como a sociedade, a escola, os professores de Educação Física e os alunos enxergarem o tema do uso de drogas.

\section{Objetivo}

Investigar se a temática das drogas é abordada nas aulas de Educação Física de escolas públicas de Fortaleza/Ceará.

\section{Método}

A pesquisa se deu em duas escolas da rede de ensino público de Fortaleza/CE, que foram escolhidas pelo pesquisador em caráter arbitrário. O estudo se caracteriza por ser de caráter quali-quantitativa, utilizando-se do Materialismo Histórico e Dialético como método de análise da realidade. Os sujeitos investigados foram dois professores de Educação Física e vinte educandos presentes em suas respectivas aulas, que foram escolhidos arbitrariamente pelo pesquisador.

Conforme Demo (1987, p. 23), pesquisa é “a atividade científica pela qual descobrimos a realidade". Entretanto, pretendíamos não só descobrir tal realidade, mas também analisá-la de modo crítico, para que seja possível compreender o conjunto dos elementos que em essência estruturam a realidade, compreendendo-a "como um todo estruturado, no qual ou do qual um fato qualquer (classe de fatos, conjunto de fatos) pode vir a ser racionalmente compreendido" (KOSIK, 1976, p. 35 apud GAMBOA, 1998, p. 27). Deste modo, entendemos que o fenômeno das drogas não pode ser compreendido aparte desse todo estruturado da realidade, da educação e especificamente, da Educação Física.

Assim, a investigação se caracterizou por realizar uma investigação bibliográfica e de campo. No referencial teórico, realizamos uma exposição histórica acerca das drogas e seus usos, desde suas origens na sociedade primitiva, sua relação ontológica com o trabalho, até os dias atuais, explicitando como o tema se interrelaciona com a sociedade, a educação, a escola e, por fim, a Educação Física. 
Posteriormente, apresentamos nossa pesquisa de campo, que tem como percurso metodológico a coleta e análise de dados. Como afirma Deslandes (1994, p. 43):

A metodologia não só contempla a fase de exploração de campo (escolha do espaço da pesquisa, escolha do grupo de pesquisa, estabelecimento dos critérios de amostragem e construção de estratégias para entrada em campo) como a definição de instrumentos e procedimentos para análise dos dados.

Assim sendo, como ferramentas de investigação utilizamos dois questionários, sendo um para os professores e o segundo para seus alunos presentes nos dias de aplicação dos questionários, sendo que, os alunos participantes da investigação foram escolhidos aleatoriamente pelo pesquisador e professores.

Os questionários foram aplicados nos dias 25 de outubro de 2013 na escola "A" e dia 29 de outubro de 2013 na escola "B", ambos no turno da manhã. Tiveram por objetivo principal coletar dados que possibilitassem realizar uma investigação verificando se a temática das drogas é abordada nas aulas de Educação Física de escolas públicas de Fortaleza/Ceará. Em específico os questionários almejavam: a) verificar, a partir da formação dos professores de Educação Física, quais os conhecimentos mobilizados para desenvolver os conteúdos acerca da temática das drogas e b) identificar as drogas mais usadas pelos alunos.

A pesquisa parte da concepção materialista histórica, ou seja, da dialética materialista histórica para analisar a realidade tendo, portanto, determinada concepção de mundo, homem e sociedade. Nesse sentido, Gamboa (1999, p. 107) afirma que:

A visão de mundo, entendida como percepção organizada da realidade que orienta a produção da pesquisa, se constrói através da prática cotidiana do pesquisador e das condições concretas da sua existência. Isto é, a visão de mundo, que organiza, como categoria mais complexa e abrangente, os diversos elementos implícitos na concreticidade de uma determinada opção epistemológica, é a responsável pelas opções de caráter técnico, metodológico, teórico, epistemológico e filosófico que o pesquisador faz durante o processo de investigação. 
No que diz respeito à dialética materialista histórica, Frigotto (1999, p. 73) afirma:

\begin{abstract}
Enquanto uma postura, ou concepção de mundo; enquanto um método que permite a apreensão radical (que vai à raiz) da realidade e, enquanto práxis, isto é, unidade de teoria e prática na busca da transformação e de novas sínteses no plano do conhecimento e no plano da realidade histórica.
\end{abstract}

Desse modo, podemos dizer que a perspectiva materialista histórica se fundamenta no entendimento de que o raciocinar dos homens, suas consciências, nada mais são que reflexos, organizados no pensamento das realidades e leis do mundo exterior. A dialética está situada "no plano da realidade, no plano histórico, sob a forma de uma trama de relações contraditórias, conflitantes, de leis de construção, desenvolvimento e transformação dos fatos" (FRIGOTTO, 1999, p. 75). Essa perspectiva se utiliza de categorias básicas como a luta de classes, totalidade, contradição, mediação, ideologia, práxis, alienação, essência, aparência, dentre outras. Para Lenin (2003, p. 18):

A dialética compreende aquilo que hoje se chama teoria do conhecimento ou gnosiologia, teoria que deve também encarar o seu objeto do ponto de vista histórico, estudando e generalizando a origem e o desenvolvimento do conhecimento, a passagem da 'ignorância' ao conhecimento.

Freitas (2003) afirma que o método dialético possui (ao menos no plano conceitual), momentos distintos, sendo que o primeiro é o da representação, do empírico (concreto-empírico ao abstrato), que não é em si o conhecimento, mas princípio dele, e que ganha corpo a partir de determinações abstratas, permitindo a formação de conceitos. Já o segundo momento relaciona-se as relações da parte com o todo, ou das partes com a totalidade, fazendo um caminho contrário à abstração analítica, passando da abstração à totalidade concreta (concreto pensado).

Desse modo, podemos dizer que o marxismo, através da dialética, parte de uma concepção de mundo que compreende a realidade como totalidade concreta, historicamente construída pelos homens, onde ele é o principal agente construtor e transformador dela. 
Assim, é necessário destacar que o uso de drogas ao decorrer da história e na atualidade não foge, portanto, ao movimento da realidade, da totalidade das relações, da categoria da luta de classes.

Conforme apresentado no segundo capítulo da pesquisa, o uso de drogas atualmente é alvo constante de reportagens das mídias jornalísticas, televisivas, dentre outras, que trazem comumente informações descompassadas, contraditórias no que diz respeito ao uso de drogas e corroboram para a formação de uma filosofia espontânea ou do chamado senso comum no que se referem às drogas, seus usos, etc. Assim, se faz necessário a busca por compreender esse fenômeno em sua essência através do método dialético, analisando a realidade no sentido de compreensão da "raiz" dos problemas. A realidade, através do conhecimento empírico nos possibilita a formação de conceitos, que como nos apresentou Freitas (2003), não se caracteriza como conhecimento em si, mas princípio dele. Apenas a análise crítica de nossa consciência e da realidade, objetivando a compreensão dos elementos estruturados em sua essência (e não somente em sua aparência), nos possibilitará a formação de uma consciência crítica, filosófica, questionadora, autônoma no que diz respeito às drogas, seus usos, etc.

\section{Resultados e Discussão}

Apresentaremos a seguir os resultados de nossa pesquisa que conforme expusemos em nossa metodologia, foram obtidos através da aplicação de questionários. Os sujeitos investigados foram dois professores da disciplina de Educação Física de duas escolas da rede de ensino público de Fortaleza/CE, que denominaremos de escola (A) e (B), e seus respectivos alunos. No intuito de facilitar a interpretação dos dados pelos leitores apresentaremos os resultados decompostos em duas partes, sendo que a primeira delas refere-se à análise referente aos dados coletados junto aos professores e posteriormente de seus alunos. Classificamos a investigação com os docentes da seguinte forma: professor da escola A: (PA) e o da escola B: (PB). 


\section{a) Professores}

Foram investigados dois professores, (PA) e (PB), sendo ambos do sexo masculino com idades de 48 e 36 anos, respectivamente. A aplicação dos questionários foi realizada nos dias 25 de outubro de 2013 na escola (A) e 29 de outubro de 2013 na escola (B), ambas no turno da manhã. Quando questionados sobre suas formações profissionais o (PA) afirmou ter o curso de especialista e o (PB) o de mestre. No que se refere ao tempo de serviço em que lecionam nas escolas inquiridas, o (PA) respondeu trabalhar há um ano e o (PB) há dez anos. Foi indagado aos professores quais as suas concepções de Educação Física. Foram encontradas as seguintes respostas:

Disciplina que atua na educação corporal e mental (PA).

A Educação Física é um dos pilares da vida. A prática de atividade física é essencial para a qualidade de vida. Sendo assim, educar o corpo se faz uma necessidade básica. A educação do corpo perfaz o caminho para a felicidade, pois trabalha além do corpo a alma e a mente (PB).

Através das respostas obtidas é possível observar que os professores enfatizam a importância da Educação Física na educação corporal e mental, aparecendo esse discurso em ambas às respostas. Contudo, entendemos ser a Educação Física “uma prática pedagógica que, no âmbito escolar, tematiza formas de atividades expressivas corporais como: jogo, esporte, dança, ginástica, formas estas que configuram uma área de conhecimento que podemos chamar de cultura corporal" (SOARES et al., 1992, p. 50). É válido destacar que os conteúdos da cultura corporal aparecem na resposta do (PB) “Esportes individuais e coletivos, jogos recreativos e cooperativos, danças, lutas", bem como temas transversais; drogas, violência, dentre outros. Entretanto, o (PA) referiu-se apenas aos conteúdos "saúde, esporte, política".

De forma geral, podemos dizer que os conteúdos surgem de conteúdos culturais universais. Para Libâneo (1985, p. 39), “os conteúdos são realidades exteriores aos alunos que devem ser assimilados e não simplesmente reinventados, eles não são fechados e refratários às realidades sociais", pois, "não basta que os conteúdos sejam ensinados, ainda que bem ensinados é preciso que se liguem de forma indissociável a sua significação humana e social." Soares et al. (1992) elencam alguns princípios 
relevantes para a seleção dos conteúdos, tais como a relevância social, contemporaneidade, a adequação às possibilidades sociocognoscitivas do aluno e a simultaneidade desses enquanto dados da realidade.

\footnotetext{
Os princípios da seleção do conteúdo remetem à necessidade de organizá-lo e sistematizá-lo fundamentado em alguns princípios metodológicos, vinculados à forma como serão tratados no currículo, bem como à lógica com que serão apresentados aos alunos. Inicialmente ressalta-se o princípio do confronto e contraposição de saberes, ou seja, compartilhar significados construídos no pensamento do aluno através de diferentes referências: o conhecimento científico ou saber escolar é o saber construído enquanto resposta às exigências do seu meio cultural informado pelo senso comum (SOARES et al., 1992, p. 31).
}

Já Saviani (2005) afirma que o homem não se faz homem sozinho, ou seja, não nasce sabendo pensar, sentir, agir ou avaliar. Para isso é necessário aprender, o que sugere em trabalho educativo, sistematizado ou não. No caso da escola o saber deve ser selecionado, organizado segundo uma lógica e deve-se tomar como referência o saber objetivo acumulado historicamente.

Quando questionamos aos professores sobre sua autonomia pedagógica na escola, particularmente à seleção dos conteúdos abordados em suas aulas e na realização das demais atividades escolares, 100\% dos docentes afirmaram possuir autonomia pedagógica tanto na seleção dos conteúdos como nas demais atividades. Entendemos que essa autonomia é bastante importante, pois, proporciona aos professores Liberdade para organizar suas atividades e também, a possibilidade de abordar a temática das drogas nas referidas escolas.

Quando arguimos sobre o que consideram mais importante em sua prática pedagógica, quais objetivos almejam em suas aulas e qual o papel da Educação Física escolar, surgiram nas respostas o desenvolvimento do senso crítico e principalmente a formação de cidadãos. Entendemos que a Educação Física deve, em certo sentido, formar bons cidadãos. Contudo, é importante trabalhar também o conceito de cidadania, sua implicação no Estado burguês e expor os limites e as contradições implícitas nela. Cabe indicar, aqui, os elucidativos trabalhos: Educação, Cidadania e Emancipação Humana e Um Novo Horizonte para a Educação, de Ivo Tonet, onde o 
autor realiza uma análise sobre a democracia e a cidadania como valores universais, e as estratégias dos marxistas rumo à construção do socialismo.

No que se refere ao tema drogas, indagamos se os professores acreditam que o tema é relevante e se já abordaram e/ou abordam tal tema em suas aulas de Educação Física escolar. Nas respostas obtidas 100\% afirmaram que o tema é sim relevante e que já o abordaram em suas aulas, justificando-se pelos seguintes motivos: “Devido à proximidade da mesma nas escolas" (PA) e "Drogas é um tema relevante e presente na vida dos alunos" (PB). Conforme Castro e Abramovay (2005, p. 89), “As drogas estão presentes em todos os espaços da sociedade, inclusive no espaço escolar". Dessa forma, é importante fomentar os debates, palestras e aulas no âmbito escolar que tratem do tema, levando aos alunos e a comunidade informações seguras, relevantes e úteis.

Nesse sentido, entendemos que algumas disciplinas podem reservar espaço para discutir o tema, como a História, a Química e, sobretudo, a Educação Física, podendo partir de temáticas como drogas e esporte, drogas e fisiologia humana, drogas e religião, drogas e cultura, drogas e violência, drogas e a arte, drogas e economia, drogas e tráfico, drogas e estado, dentre outros (ESCOHOTADO, 1997; FREEMAN, 1989; FURST, 1989; RICHARDSON, 1988; RODRIGUES, 2008).

É válido destacar que a disponibilização de informações, bem como a prática de atividades físicas e de hábitos saudáveis de vida, tanto na escola quanto fora dela podem ajudar no combate ao uso excessivo, indiscriminado e abusivo de drogas.

Por fim, indagamos aos docentes se no decorrer de sua formação estes tiveram acesso a conhecimentos sobre drogas, seja participando de algum curso e/ou disciplina na faculdade. Nas respostas encontradas, $100 \%$ afirmaram ter conhecimentos sobre drogas, sendo que um afirmou compreender sobre anabolizantes e o segundo disse ter participado de alguns seminários que trataram o tema. Verificamos desse modo, que os professores investigados possuem alguns conhecimentos sobre drogas. Contudo, o tema drogas mostra-se bastante amplo e é necessária uma formação contínua sobre o tema. Infelizmente não é comum encontrarmos a disposição dos docentes cursos de formação continuada que complementem essa formação, demanda urgente da educação em nosso país. Não nos 
deteremos em alongar mais o debate sobre a necessidade de cursos de formação continuada sobre o fenômeno das drogas para a educação no Brasil, sobretudo para os professores de Educação Física, ficando esta discussão para outra oportunidade. Concentraremos agora na exposição dos resultados obtidos durante a investigação realizada com os alunos.

\section{b) Alunos}

Quanto à investigação empreendida com os alunos, foram aplicados questionários, sendo investigados dez sujeitos na escola (A) e dez na escola (B), num total de vinte. Na escola (A) a faixa etária encontrada foi de 16 a 18 anos. Desses, seis sujeitos se disseram ser do sexo masculino e quatro do sexo feminino. Já na escola (B) a faixa etária encontrada compreendia sujeitos de 15 a 17 anos. Destes, quatro se disseram ser do sexo masculino e seis do sexo feminino. Classificamos os alunos quanto à escola na qual estudam (A) e (B) em uma ordem crescente de uma dez. Antes de aplicarmos os questionários foi feita a leitura dos mesmos para os educandos, esclarecendo as dúvidas emergentes.

Quando indagamos aos sujeitos o que estes entendiam por droga surgiram respostas das mais diversas. Com o intuito de facilitar a compreensão do leitor, classificamos as respostas segundo as seguintes categorias: Malefícios, Dependência/vício e Senso comum.

\section{Malefícios}

Na categoria malefícios apareceram respostas, tais como:

É uma coisa que faz muito mal (A2).

É uma coisa muito ruim, pois acaba com famílias, destrói sonhos, tira muitas vidas (B3).

É algo que é muito prejudicial à saúde, em alguns casos pode causar a morte do usuário (B9). 
Para Câmara; Tambellini e Roselli-Cruz (2009, p. 220), “Droga, segundo seu termo correlato grego Phármakon, é uma palavra ambígua que expressa tanto o veneno, quanto o medicamento que cura ou salva". Escohotado (1997, p. 35) atribui também ao grego à origem do termo droga e afirma que "Phármakon é uma substância que é remédio e veneno ao mesmo tempo; não é uma coisa ou outra, mas ambas ao mesmo tempo".

Entendemos, assim, que as drogas não carregam em si apenas as consequências maléficas, mas que podem também ser úteis. As drogas são substâncias que possuem propriedades das mais diversas e que o modo como o indivíduo se utiliza destas, ou seja, a forma, a dosagem que é utilizada é que vai determinar as consequências sofridas pelo usuário, sejam elas boas ou ruins. É bem verdade que algumas drogas possuem poder letal se usadas em grandes quantidades. Evidencia-se que algumas drogas podem ocasionar a morte se utilizadas em altas doses, como a aspirina (ingestão igual ou superior a três gramas) e cianureto (ingestão igual ou superior a um décimo de grama) (ESCOHOTADO, 1997). Existem também as chamadas mortes indiretas, que frequentemente não matam pelo uso, mas sim pelos atos que seus usuários cometem quando se utilizam destas, como no caso da combinação álcool mais direção, comumente fatal.

\section{Dependência/vício}

Antes de adentrarmos as categorias da dependência e do vício é válido falar um pouco sobre as características da pré-dependência. Destarte, podemos dizer que atualmente não é possível saber quais pessoas tem maior ou menor probabilidade de desenvolver dependência por alguma substância. Algumas pesquisas que ainda estão engatinhando mostram que filhos de pais dependentes químicos têm mais probabilidade de desenvolver dependência, principalmente com o álcool e o crack. Contudo, os pesquisadores que estudam as características da pré-dependência, 
[...] trabalham retroativamente quando o vício já se estabeleceu ou estudam grandes grupos durante muitos anos, começando antes do início dos problemas do vício, registrando dependência no momento em que ela surge, e então retraçando o caminho que os viciados percorreram para achar em sua personalidade os traços que levaram ao vício (COX, 1989, p. 39).

Nesse sentido, "em razão das dificuldades para se identificar as características da personalidade pré-dependente, o método longitudinal de estudo seria o mais indicado" (COX, 1989, p. 39). Contudo, a grande dificuldade nesse tipo de estudo é que estes,

[...] são dispendiosos e difíceis de realizar. E, como as estatísticas mostram que poucas pessoas tendem a tornar-se dependentes, os testes de personalidade teriam de ser usados em um numeroso grupo de pessoas desde muito cedo em suas vidas e repetido regularmente até que alguém do grupo se tornasse viciado (COX, 1989, p. 40).

No que diz respeito à dependência, ou melhor, a dependência potencial, conceito que surge como resultado da mudança dos conceitos sobre as explicações do alcoolismo que era atribuído à fraqueza moral ou aos seus poderes demoníacos, compreendia-se que existia uma personalidade alcoólatra e que esta era a causa do consumo exacerbado de bebidas. Contudo, os pesquisadores descobriram que a dependência é "um fenômeno complexo cuja ocorrência se deve a muitos outros fatores além da personalidade" (COX, 1989, p. 34).

Entre estes fatores biológicos (reações bioquímicas a drogas psicotrópicas), fatores do meio ambiente (como pressões dos amigos), fatores socioculturais, que induzem uma pessoa a beber muito ou moderadamente, e fatores psicológicos diversos (tais como as expectativas sobre os efeitos das drogas). Qualquer indivíduo pode ser afetado em graus variados por uma ou todas estas causas (COX, 1989, p. 34-35).

Deste modo, através da análise dos questionários surgiram respostas como:

É uma substância que a pessoa se vicia (A6).

É tudo aquilo que deixa a pessoa dependente (A5).

Compreendemos que a dependência é um fenômeno complexo que não possui apenas uma única causa. Diversos fatores, dentre os quais os biológicos, 
ambientais e socioculturais podem estar envolvidos no caso de uma pessoa dependente química. Cabe salientar ainda que as drogas provocam em cada indivíduo diferentes reações e que elas possuem graus variados de capacidade viciativa. O LSD, por exemplo, é considerado uma substância com baixa capacidade de provocar dependência, enquanto o crack e a cocaína representam seu oposto (COX, 1989; EDELSON, 1989; FREEMAN, 1989; FURST, 1989; RICHARDSON, 1988).

\section{Senso comum}

Na categoria que classificamos como senso comum encontramos na análise dos questionários respostas como:

Droga pra mim é uma coisa que deixa a pessoa com delírios (B10).

Algo que deixa a pessoa paranormal, fora de si ou mesmo descontrolado (B2).

Como dito anteriormente as drogas possuem efeitos dos mais diversos e cada indivíduo reage de forma diferente quando se utiliza delas.

Também é preciso levar em consideração diversos outros fatores como a quantidade ingerida, estado emocional de quem faz uso da substância, dentre outros. Nas respostas analisadas encontramos as expressões:

Deixa a pessoa com delírios (B10).

Deixa a pessoa paranormal (B2).

É preciso conhecer os efeitos de tais substâncias e desmistificar as crendices contidas no senso comum. No caso das substâncias conhecidas como alucinógenos, por exemplo, este não é um termo muito preciso se consideramos que uma “alucinação é uma experiência imaginária, e as drogas psicodélicas não criam tais experiências. Pelo contrário, elas apenas distorcem as percepções normais" (EDELSON, 1989, p. 82). Portanto, no senso comum encontramos muitas informações errôneas sobre os efeitos que as mais variadas substâncias podem provocar. É importante, portanto, conhecer os efeitos e dispor de informações precisas para avaliar os indivíduos caso a caso. 
Quando questionamos os sujeitos investigados se já haviam presenciado ou se sabiam de algum caso de uso drogas na escola, as análises das respostas mostraram que, na escola (A), 50\% dos sujeitos afirmaram já ter presenciado ou saber algum caso de uso de drogas na escola e 50\% responderam não ter presenciado e não saber de nenhum caso de uso de drogas na escola. Já na escola (B), 60\% dos investigados afirmaram já ter presenciado ou saber de algum caso de uso de drogas na escola e 40\% responderam não ter presenciado e não saber de nenhum caso de uso de drogas na escola. Conforme trabalho publicado por Castro e Abramovay (2005, p. 89):

\footnotetext{
A escola é vista, pelos alunos, como um meio para a obtenção de um maior capital social e cultural. Entretanto, para que a escola continue exercendo sua função e seja capaz de propor ações concretas na resolução dos conflitos que se dão no seu ambiente - os quais refletem problemas internos e externos a ela, tais como a presença, a venda e o consumo de drogas -, é necessário que ela seja capaz de lidar com novos valores e novas ideias que surgem com as constantes transformações sociais.
}

Os dados analisados, bem como o referencial teórico apontam que a escola não passa imune ao fenômeno das drogas. Elas estão em todos os espaços sociais, inclusive na escola. O consumo de tais substâncias no espaço intra e extraescolar é muito grande. Na escola (A) 50\% dos sujeitos investigados afirmam já ter presenciado ou sabem de algum caso de uso de drogas dentro da escola, enquanto na escola (B) este percentual sobe para $60 \%$. Pedimos ainda, que os alunos narrassem situações em que tivessem presenciado ou soubessem de uso de drogas na escola, surgindo situações como as apresentadas a seguir:

\footnotetext{
Já soube que alguns alunos usavam droga na escola, a própria diretora falou que sabia disso (A5).

Um colega foi pego com garrafas de tequila (B5).
}

Há casos em que a própria direção da escola sabe do consumo de tais substâncias dentro das escolas, porém, muitas vezes não podem fazer muita coisa por conta do despreparo para lhe dar com a situação, medo de represálias, dentre outros. Esses dados indicam que a escola não pode mais se eximir de debater tal fenômeno, de levar informações seguras, desvinculadas de preconceitos morais. 
Questionamos também aos sujeitos investigados, se já haviam participado de alguma aula de Educação Física com o tema drogas. Na escola (A), 30\% afirmaram já ter participado de alguma aula de Educação Física com o tema drogas e 70\% disseram nunca ter tido tal oportunidade. Já na escola (B) apenas 20\% afirmaram já ter participado de alguma aula de Educação Física com o tema drogas e 80\% disseram nunca ter participado de aulas de Educação Física com o tema drogas. Esses dados apontam que o tema drogas é pouco abordado nas aulas de Educação Física e que existem ainda muitos tabus em sua abordagem.

Indagamos também se os sujeitos conhecem alguém que tem problemas com o uso excessivo de drogas. Na escola (A), 90\% afirmam conhecer pessoas que tem problemas com o uso excessivo de drogas e 10\% disseram não. Já na escola (B), 70\% dos investigados afirmaram conhecer pessoas que tem problemas com o uso excessivo de drogas e 30\% afirmaram não conhecer ninguém com tal problema. Pedimos ainda que os sujeitos narrassem tais situações, surgindo narrativas como:

Tem um cara que mora perto da mina casa. Ele está doido de tanto cheirar cocaína. Ele fica nu na rua e bate nos cachorro (A1).

Tenho uma amiga. Tem dias que ela passa fome para usar a pedra maldita. Ela é bem magrinha. Tenho pena dela (B2).

Meu vizinho usa maconha todos os dias e bebe todos os dias (B10).

Podemos compreender através dos dados coletados e analisados que é muito alto o percentual de alunos que conhecem pessoas que tem problemas com o uso excessivo de algumas drogas. Foram narradas situações bastante adversas. Estas situações fazem parte do cotidiano dos educandos e faltam-lhes informações de como lhe dar com tais situações e de como agir em determinados casos.

Quando indagamos aos sujeitos se em sua família tem alguém com problemas relativos ao uso excessivo de drogas, 50\% afirmaram que em sua família há pessoas com problemas relativos ao uso excessivo de drogas e 50\% disseram não haver em sua família pessoas com tal problema, na escola (A). Já na escola (B) 80\% afirmaram que sim, em sua família há pessoas com problemas relativos ao uso excessivo de drogas e $20 \%$ disseram não haver em sua família pessoas com tal problema. Deste 
modo, os dados apontam que além dos educandos em ambas as escolas conhecem e vivenciam situações em que as drogas são usadas de modo indiscriminado fora de seus lares, muitos também enfrentam tal situação em sua própria casa, em seu seio familiar. Pedimos ainda que os sujeitos descrevessem situações em que ocorre o uso excessivo de drogas, obtendo, dentre as respostas:

Meu tio é um usuário de drogas (A4).

A maioria dos meus tios faz uso excessivo de álcool (B3).

Minha avó fuma muito. Ela chega a fumar duas carteiras de cigarro por dia (B9).

Podemos perceber que drogas lícitas, tais com álcool e cigarro são bastante consumidas na realidade investigada e que fazem parte do cotidiano dos alunos.

Inquirimos ainda aos sujeitos se já haviam feito uso de alguma droga. $\mathrm{Na}$ escola (A), 80\% afirmaram já ter usado alguma droga e 20\% disseram nunca ter usado drogas. Desses $80 \%$ que afirmaram já ter usado alguma droga quatro afirmaram já ter usado álcool, oito afirmaram já ter usado café, três afirmaram já ter usado fármacos e um afirmou já ter usado cigarro. Já na escola (B) 100\% dos sujeitos afirmaram já ter usado alguma droga. Desses, três afirmaram ter usado álcool, nove afirmaram ter usado café, cinco afirmaram ter usado fármacos e um afirmou já ter usado maconha. Os dados coletados apontam que o uso das drogas lícitas é maior que o das drogas ilícitas. A facilidade no acesso a tais substâncias, a aceitação das mesmas pela sociedade, o incentivo dos amigos, bem como outros fatores são apontados como as principais causas para tal índice (COX, 1989; EDELSON, 1989; FREEMAN, 1989; FURST, 1989; HENNINGFIELD, 1988; RICHARDSON, 1988).

Perguntamos também se os sujeitos costumam fazer uso de alguma droga. Na escola (A), 60\% dos alunos afirmaram ter costume de usar alguma droga e 40\% disseram não. Dentre esses $60 \%$ que afirmaram ter costume de usar alguma droga, três se classificaram sendo um usuário eventual/ocasional, um afirmou ser apenas experimentador, um se disse ser usuário habitual de alguma droga e um afirmou ter o costume de fazer outros tipos de uso de drogas, enquanto na escola (B) 80\% afirmaram ter costume de usar alguma droga e $20 \%$ disseram não. Dentre esses $80 \%$ que 
afirmaram ter costume de usar alguma droga, dois se classificaram sendo um usuário eventual/ocasional, um afirmou ser apenas experimentador, cinco se disseram ser usuário habitual de alguma droga e um afirmou ter o costume de fazer outros tipos de uso de drogas. Assim, é alto o índice de educandos que fazem uso de droga dos mais diferentes tipos.

Por fim, perguntamos aos sujeitos qual (is) tipo (s) de uso (s) de drogas você costuma fazer. $\mathrm{Na}$ escola (A) cinco sujeitos afirmaram fazer uso comemorativo/festivo, um afirmou fazer uso curativo, um afirmou usar drogas para atividades de labor/trabalho, dois disseram fazer uso medicinal, um afirmou fazer uso nutricional de drogas, dois afirmaram fazer uso recreativo de drogas e um sujeito afirmou fazer outros tipos de uso de drogas, enquanto que na escola (B), um sujeito afirmou fazer uso comemorativo/festivo de drogas, sete afirmaram fazer uso medicinal de drogas, um afirmou fazer uso nutricional de drogas e um afirmou fazer uso recreativo de drogas. É grande também o uso de drogas entre os estudantes dos mais variados tipos. Contudo, destacamos o uso laboral de drogas, realizado por um sujeito. Fora da escola esta prática é muito comum, sobretudo entre trabalhadores rurais que cortam cana de açúcar e também trabalhadores que atuam no transporte de cargas, com drogas como crack, injeções amarelinhas, medicamentos e arrebites (SILVA, 2010).

\section{Conclusão}

Apresentaremos agora as conclusões de nossa pesquisa. Destarte, podemos afirmar o Materialismo Histórico e Dialético como método de análise da realidade compreendendo-a "como um todo estruturado, no qual ou do qual um fato qualquer (classe de fatos, conjunto de fatos) pode vir a ser racionalmente compreendido" (KOSIK, 1976, p. 35 apud GAMBOA, 1998, p. 27). Como supracitado, o fenômeno das drogas não pode ser compreendido de modo isolado deste todo estruturado. É necessário buscar compreender as relações que estruturam tal fenômeno para assim, conjeturar uma visão de totalidade. 
Afirmamos através das referências bibliográficas citadas e dos dados colhidos e interpretados da realidade que a temática das drogas é sim abordada em algumas aulas de Educação Física de escolas públicas de Fortaleza/CE. Entretanto, o tema ainda é insuficientemente abordado, sendo que na escola (A) apenas 20\% dos alunos afirmaram já ter participado de aulas de Educação Física com tal tema e na escola (B) somente $30 \%$.

No que diz respeito à formação dos professores, especificamente dos conhecimentos que estes possuem para desenvolver suas aulas no que se refere às drogas, a sua formação mostrou-se insuficiente, precária. Os dados colhidos apontaram que os sujeitos investigados afirmaram compreender sobre anabolizantes (PA) e participado de alguns seminários durante sua formação inicial (PB). Faltam cursos de formação continuada em âmbito nacional e estadual que complemente e aperfeiçoe suas formações acerca das drogas.

Os dados apontaram ainda que as drogas mais usadas pelos alunos são as drogas lícitas, sendo que dezessete alunos afirmaram já ter usado e/ou usar café, oito disseram já ter usado e/ou usar fármacos, sete asseguraram já ter usado e/ou usar álcool, um afirmou já ter usado e/ou usar cigarro e apenas um disse já ter usado e/ou usar maconha.

Compreendemos através da análise dos dados que, na realidade investigada o uso de drogas lícitas encontrando drogas como o café, o álcool, os fármacos e o cigarro é bem maior que o de substâncias ilícitas, deparando-nos apenas com a maconha. Portanto, as drogas estão cada vez mais presentes no espaço escolar.

Nesse sentido, os professores de Educação Física, possuindo conhecimentos sobre tal fenômeno, podem intervir na realidade de modo que possam levar informações seguras e despertar em seus alunos o interesse pelo tema, fomentando assim a autonomia e criticidade de seus alunos sobre as drogas.

Para o pesquisador permanece um saldo de aprendizado sobre o fenômeno das drogas e seus usos, suas nuances, a sensação de ter alcançado os objetivos almejados, de dever cumprido e o desejo de continuar realizando trabalhos nesse campo de pesquisa. 


\section{Referências}

BATISTA, Rafael. Drogas. [S.l.]: Brasil Escola, [20--]. Disponível em: http:// www.brasilescola.com/drogas/. Acesso em: 18 jul. 2013.

BRASIL. Lei n 8.069, de 13 de julho de 1990. Dispõe sobre o Estatuto da Criança e do Adolescente e dá outras providencias. Diário Oficial [da] República Federativa do Brasil: seção 1, Brasília, DF, 16 jul. 1990. Disponível em:

http:// www.planalto.gov.br/ccivil_03/leis/18069.htm. Acesso em: 8 jan. 2014.

BRASIL. Secretaria de Educação Fundamental. Parâmetros curriculares nacionais: educação física. Brasília, DF: Ministério da Educação, 1998.

BRASIL. Secretaria de Educação Fundamental. Parâmetros curriculares nacionais: educação física. Brasília, DF: Ministério da Educação, 1997.

CÂMARA, Martial de Magalhães; TAMBELLINI, Ana Maria Testa; ROSELLI-CRUZ, Amadeu. Trabalho, abuso de drogas e os aparelhos ideológicos de Estado: um estudo com alunos do ensino médio e fundamental. Physis: Revista de Saúde Coletiva, Rio de Janeiro, v. 20, n. 1, p. 219-234, 2010.

CARNEIRO, Henrique Soares. Autonomia ou heteronomia nos estados alterados de consciência. In: LABATE, Beatriz Caiuby et al. (org.). Drogas e cultura: novas perspectivas. Salvador: EDUFBA, 2008. 440 p.

CASTRO, Mary Garcia; ABRAMOVAY, Miriam. Drogas nas escolas: versão resumida. Brasília, DF: UNESCO: Rede Pitágoras, 2005. 143 p.

COX, W. Miles. Tudo sobre drogas: personalidade do viciado. São Paulo: Nova Cultural, $1989.72 \mathrm{p}$.

DARIDO, Suraya Cristina; SOUZA JÚNIOR, Osmar Moreira de. Para ensinar educação física: possibilidades de intervenção na escola. 4. ed. Campinas: Papirus, 2007.

DEMO, Pedro. Introdução à metodologia da ciência. 2. ed. São Paulo: Atlas, 1987. $118 \mathrm{p}$.

DESLANDES, Suely Ferreira. A construção do projeto de pesquisa. In: MINAYO, Maria Cecília de Souza (org.). Pesquisa social: teoria, método e criatividade. 14. ed. Petrópolis: Vozes, 1994. 80 p.

EDELSON, Edward. Tudo sobre drogas: efeitos no cérebro. São Paulo: Nova Cultural, 1989.93 p. 
ESCOHOTADO, Antonio. O livro das drogas: usos e abusos, desafios e preconceitos. São Paulo: Dynamis Editorial, 1997. 272 p.

FREEMAN, Sally. Tudo sobre drogas: na rota do vício. São Paulo: Nova Cultural, 1989. $84 \mathrm{p}$.

FREITAS, Luís Carlos de. Crítica da organização do trabalho pedagógico e da didática. 6. ed. São Paulo: Papirus, 2003. (Coleção magistério formação e trabalho pedagógico).

FRIGOTTO, Gaudêncio. O enfoque da dialética materialista histórica na pesquisa educacional. In: FAZENDA, Ivani (org.). Metodologia da pesquisa educacional. 3. ed. São Paulo: Cortez, 1999. p. 69-90. (Biblioteca da Educação. Série 1. Escola, v. 11).

FURST, Peter E. Tudo sobre drogas: cogumelos psicodélicos. São Paulo: Nova Cultural, 1989. 94 p.

GAMBOA, Silvio Sánchez. A dialética na pesquisa em educação: elementos de contexto. In: FAZENDA, Ivani (org.). Metodologia da pesquisa educacional. 3. ed. São Paulo: Cortez, 1999. p. 69-90. (Biblioteca da Educação. Série 1. Escola, v. 11).

GAMBOA, Silvio Sánchez. Epistemologia da pesquisa em educação. Campinas: Práxis, 1998. 155 p.

KOSIK, Karel. Dialética do concreto. Tradução de Célia Neves e Alderico Toríbio. 2 ed. Rio de Janeiro: Paz e Terra, 1976.

LENIN, V. I. As três fontes e as três partes constitutivas do marxismo. 2. ed. São Paulo: Expressão Popular, 2003.

LENIN, Vladimir Ilitch. O estado e a revolução: 1917-18. [S.l.: s.n.], [20--]. Disponível em:

https://www.marxists.org/portugues/lenin/1917/08/estadoerevolucao/index.htm . Acesso em: 21 ago. 2013.

LIBÂNEO, José C. Democratização da escola pública: a pedagogia crítico-social dos conteúdos. 19. ed. São Paulo: Loyola, 1985.

A LIGA: crack. São Paulo: Rede Bandeirantes de Televisão, 2012. 1 vídeo. Publicado pelo canal Tegumentos. Disponível em:

http://www.youtube.com/watch?v=tu_P2nAz_1M. Acesso em: 18 jul. 2013.

LSD completa 70 anos. O Povo Online, Fortaleza, 7 maio 2013. Notícias. 
LUKÁCS, Georg. História e consciência de classe: estudos sobre a dialética marxista. Tradução Rodnei Nascimento. São Paulo: Martins Fontes, 2003. 598 p. Título original Geschichte Und Klassenbewusstsein.

RICHARSON, P. Mick. Tudo sobre drogas: flores alucinógenas. São Paulo: Nova Cultural, 1988. 71 p.

RODRIGUES, Thiago. Tráfico, guerra, proibição. In: LABATE, Beatriz Caiuby et al. (org.). Drogas e cultura: novas perspectivas. Salvador: EDUFBA, 2008. 440 p.

SANTOS, Luciane dos. Moro no mundo e passeio em casa: vida e trabalho dos caminhoneiros. In: ANTUNES, Ricardo; SILVA, Maria A. Moraes (org.). O avesso do trabalho. 2. ed. São Paulo: Expressão Popular, 2010. 333 p.

SAVIANI, Dermeval. Escola e democracia. 38. ed. Campinas: Autores Associados, 2006. 94 p.

SAVIANI, Dermeval. Pedagogia histórico-crítica: primeiras aproximações. 9. ed. Campinas: Autores Associados, 2005. 156 p.

SILVA, Maria A. Moraes. Se eu pudesse, eu quebraria todas as máquinas. In:

ANTUNES, Ricardo; SILVA, Maria A. Moraes (org.). O avesso do trabalho. 2. ed. São Paulo: Expressão Popular, 2010. 333 p.

SOARES, Carmen Lúcia et al. Metodologia do ensino de educação física. São Paulo: Cortez, 1992. 


\section{4}

Segurança do paciente: Gasometria como boas

práticas na assistência do enfermeiro 


\title{
14 SEGURANÇA DO PACIENTE: GASOMETRIA COMO BOAS PRÁTICAS NA ASSISTÊNCIA DO ENFERMEIRO
}

\author{
Jennifer Késsya Rebouças de Oliveira \\ Daniele Vasconcelos Fernandes Vieira \\ Gislene Holanda de Freitas \\ lvando Amâncio da Silva Júnior \\ Camila Pimentel de Souza \\ Elisângela Tavares da Silva
}

\section{Resumo}

Introdução: A Gasometria Arterial é um exame que diariamente alguns pacientes são submetidos dentro da Unidade de Terapia Intensiva (UTI), que visa buscar informações sobre a situação respiratória, do $\mathrm{pH}$ e do equilíbrio ácido-básico do paciente. Por se tratar de um exame rotineiro, o enfermeiro deve ser um dos principais responsáveis pelo exame, pois o mesmo demanda conhecimento técnico-científico para executá-lo de forma segura, evitando danos ao paciente. Objetivo: Avaliar o conhecimento do enfermeiro de uma UTI, sobre a utilização de gasometria arterial como boas práticas de enfermagem na segurança do paciente. Métodos: Realizou-se um estudo descritivo-exploratório, do tipo qualitativo, em um hospital quaternário da cidade de Fortaleza-Ceará. Participaram das entrevistas semiestruturadas, 11 enfermeiros e aplicou-se um checklist para descrição sobre o conhecimento do enfermeiro quanto à segurança do paciente em relação à gasometria. Resultados: Constatou-se que os enfermeiros não realizam a gasometria arterial na UTI, com relato de conhecimento limitado sobre o assunto, pois não é um procedimento deles no setor, apesar da Resolução do Conselho Federal de Medicina (COFEN) - 390/2011 normatizar a execução, pelo enfermeiro, da punção arterial, tanto para fins de gasometria como para monitorização de pressão arterial invasiva (BRASIL, 2011). Contudo, sem a habilidade necessária para realizar a coleta, interpretação e possíveis intervenções, bem como aplicabilidade na rotina do enfermeiro, a avaliação dessa prática de enfermagem fica fragilizada. Isso é preocupante, pois os distúrbios ácidobásico podem levar o paciente ao coma e até mesmo à morte. Considerações finais: Como a gasometria um procedimento de rotina na UTI, o enfermeiro deve apropriarse desse procedimento, com vistas a garantir maior segurança para a realização da gasometria.

Palavras-chave: Enfermagem. Gasometria. Segurança do Paciente. 


\section{Introdução}

Existe uma preocupação multiprofissional sobre a questão das complicações em pacientes internados em Unidades de Terapia Intensiva, no tocante aos desequilíbrios homeostáticos concernentes aos parâmetros ácido-base dos indivíduos assistidos. Contudo, na experiência cotidiana de Hospitais de grande porte o que se percebe na realidade é que a gasometria arterial passa a ser mais um exame, sem sua devida importância, anexada ao prontuário, como complemento, de encargo médico, tanto no sentido da interpretação, como no juízo das condutas a serem adotadas, no tocante à prevenção dos danos oriundos das instabilidades constantes que afetam esses pacientes.

Assim, nesta pesquisa, será problematizado o conhecimento e, portanto, a atuação do enfermeiro diante dos riscos hemodinâmicos que passa um paciente no contexto da UTI, tendo o enfoque de discussão direcionado para o procedimento da Gasometria Arterial, uma vez que autores atestam a sua importância na segurança do paciente, com impacto na prevenção, recuperação quanto aos seus quadros clínicos de riscos iminentes.

Conforme Mota et al. (2013), é de fundamental importância que haja percepção e conhecimento sobre os distúrbios ácido-base no paciente, principalmente quando ele se encontra na UTI, já que na maioria das vezes os pacientes apresentamse instáveis, com risco eminente maior de vida. Além disso, os distúrbios ácido-base podem ser muitas vezes irreversíveis, quando alcançam um nível muito abaixo ou muito acima do padrão aceitável para o ser humano, podendo levar a falência de órgãos e por sua vez ao óbito.

Furoni et al. (2010) corroboram com essa afirmativa ao apontar que os limites de pH sanguíneo compossível com a vida, situam-se entre 6,8 e 8,0. Sendo assim, essas variações do equilíbrio ácido-básico (EAB) são potencialmente críticas, principalmente, quando são desenvolvidas de forma abrupta. Essas alterações no EAB podem causar diversas disfunções orgânicas, como edema cerebral, falência de órgãos, decréscimo da contratilidade miocárdica, vasoconstrição pulmonar, vasodilatação sistêmica, dentre outras. 
Os valores de normalidade dos gases, que devem ser encontrados no ser humano são de: $\mathrm{O}$ pH; 7,35 a 7,45; pO2 (pressão parcial de oxigênio); 80 a 100 mmHg; pCO2 (pressão parcial de dióxido de carbônico); 35 a 45 mmHg; HCO3 (necessário para o equilíbrio ácido-básico sanguíneo); 22 a 26 mEq/L; SaO2 Saturação de oxigênio (arterial); maior que 95\% (SANDERSON, 2012).

Quando o organismo concentra uma quantidade de ácidos provenientes do metabolismo, o pH do sangue se estrema; podendo-se assim dizer que estamos a frente de uma acidose e, de natureza metabólica. Já no acúmulo de CO2, não eliminado devidamente pela ventilação, o pH se reduz; dizemos que a acidose é de caráter respiratória pelo acúmulo de C02 (FURONI et al., 2012).

Assim, o monitoramento dos parâmetros ácido-base dos pacientes é um aspecto fundamental na segurança do paciente, desde que o enfermeiro tenha conhecimento adequado para reconhecer padrões de anormalidades de desequilíbrio ácido-básico.

De acordo com Oliveira e Souza (2012), a UTI é um ambiente complexo, onde conta com vários tipos de tecnologias, principalmente tecnologias classificadas como duras, por levarem resultados obtidos através do uso de equipamentos como instrumento de trabalho. Junto a ela se associa outros dois tipos de tecnologias, levedura e leve, que respectivamente se diz a respeito do conhecimento técnico em manusear as aparelhagens existentes no âmbito da UTI, já a outra é responsável pela relação direta entre profissional e paciente.

Devido a essa complexidade, os profissionais devem sempre buscar pelo cuidado seguro, que é um desafio constante para eles, uma vez que a UTI conta com diversas tecnologias e processos terapêuticos diversos, exigindo dos profissionais um conhecimento mais ampliado (TAVARES, 2013).

Por ser um ambiente tão complexo, que atende pacientes com risco iminente de morte, muitas vezes exigem-se decisões polêmicas e ágeis por parte dos profissionais que ali atuam, envolvendo os mesmos em situações extremistas e de estresse. Tornando-se assim um risco e uma porta para o erro, pois decisões rápidas e situações estressantes fazem com que a atenção do profissional fique prejudicada (FLOR; VARGAS, 2012). 
Sabe-se que esse ambiente pode tornar-se inseguro quando há descumprimentos de protocolos de segurança, portanto, vemos a necessidade de proteger um indivíduo fragilizado, que se encontra em risco de morte, vulnerável e, muitas vezes, sem condições psicológicas de responder por si mesmo (TAVARES, 2013).

A Gasometria Arterial (GA) é um procedimento de atribuição do enfermeiro que demanda conhecimento técnico-científico para a sua realização, os resultados do exame são obtidos através da coleta de sangue arterial e analisado pelo gasômetro, que podem trazer os níveis de PaCO2 que é a pressão parcial de gás carbônico existente nos pulmões, assim como a pressão parcial de oxigênio PaO2 (SOLER; SAMPAIO; GOMES, 2012).

A amostra de sangue arterial traz informações acerca do pH sanguíneo que avalia as questões dos distúrbios acidobásicos. Dependendo do quadro do paciente ele pode se apresentar acidótico, quando o nível do $\mathrm{pH}$ fica abaixo de 7 e alcalótico quando o pH fica acima de 7 (SOLER; SAMPAIO; GOMES, 2012).

Com base nos distúrbios, Rolim et al. (2013) trazem uma pauta sobre a necessidade do exame ser realizado rotineiramente, pois por se tratarem de pacientes graves e que muitas vezes apresentam instabilidades ventilatórias, hemodinâmicas e descontrole do equilíbrio ácido-base.

O exame de GA, para que os profissionais da unidade tomem decisões acerca de cada interpretação e prestem os devidos cuidados específicos para o paciente, vindo até prevenir futuros riscos. É imprescindível que o enfermeiro da unidade de terapia intensiva tenha conhecimento técnico-científico sobre a coleta e a interpretação dos resultados da amostra, pois ao perceber algum parâmetro fora do padrão ele poderá intervir antes que o paciente apresente quadros de instabilidades ventilatória ou metabólica, distúrbios de órgãos e evoluir para o óbito.

Reconhecendo a importância da GA na prevenção e monitoramento desses desequilíbrios, busca-se com essa pesquisa conhecer como o enfermeiro atualiza e incorpora essa prática no seu cotidiano de assistência UTI, estabelecendo relações de seu conhecimento com a segurança do paciente, no tocante as Boas Práticas em Saúde. 
Esta pesquisa se justifica pela realidade que presenciamos nas UTI, onde, predominantemente, quem realiza esse procedimento é o técnico de laboratório. Sendo que é necessário uma série de cuidados antes e depois do exame, tanto com o paciente e o sangue colhido, pois existem vários fatores que podem alterar o exame, como a exposição a temperatura, a própria técnica da coleta entre outros.

Na maioria das situações a coleta é realizada pelo técnico de laboratório, porém de acordo com a resolução do COFEN - 390/2011, a coleta deve ser realizada pelo Enfermeiro, pois por se tratar de um exame complexo, o mesmo requer conhecimento técnico cientifico para a realização e interpretação, já que o enfermeiro pode realizar, mas demonstrar o diferencial dessa prática quando realizada pelo enfermeiro é relevante, uma vez que é sua atribuição e influencia diretamente na preservação do equilíbrio ventilatório e metabólico do paciente (BRASIL, 2011).

Portanto, a relevância do estudo encontra-se na necessidade de ampliar as discussões sobre as boas práticas do enfermeiro na Unidade de Terapia Intensiva, atentando para a prevenção de complicações aos pacientes, sob a perspectiva de um eficiente monitoramento dos parâmetros de estabilidade tendo como base o conhecimento sobre a gasometria arterial, no tocante à coleta, interpretação, monitoramento. Espera-se trazer contribuições para que o enfermeiro valorize esse exame como uma boa prática de enfermagem na segurança do paciente.

\section{Objetivo}

Identificar o conhecimento dos enfermeiros de uma Unidade de Terapia Intensiva sobre a utilização da gasometria arterial como boas práticas de enfermagem na segurança do paciente.

\section{Método}

Realizou-se uma pesquisa descritivo exploratório, com abordagem qualitativa, nas UTI, adulto, do Hospital Geral de Fortaleza (HGF), no período de janeiro a março de 2018, em Fortaleza-CE. O HGF é um hospital público, de caráter 
terciário. É referência Norte e Nordeste, especializado em desenvolver assistência de alta complexidade. O hospital foi inaugurado em 23 de maio de 1969, é o maior hospital público da rede estadual, referência em procedimentos de alta complexidade, realiza transplantes de fígado, pâncreas, rins, entre outros, realiza também neurocirurgias. Em 2009, o hospital inaugurou a unidade especializada em Acidente Vascular Cerebral (AVC), essa unidade representa um marco para a saúde pública do estado do estado do Ceará. Atualmente o hospital encontra-se com 38 leitos de UTI, adulto, sendo que os leitos são subdivididos em três unidades: Amarela, Verde e Azul. Cada unidade possui seu coordenador específico, contando com 01 gerente de Enfermagem e 01 coordenador médico para todas elas. A equipe de enfermagem segue o dimensionamento de 01 enfermeiro para cada 04 pacientes, e 01 técnico de enfermagem para cada 02 leitos.

Os sujeitos da pesquisa foram selecionados por meio de amostragem por conveniência. A amostra da pesquisa foi composta por 11 enfermeiros de ambos os sexos, das três unidades de terapia intensiva. Foram incluídos os (as) enfermeiros (as) com escalas fixas que exercem função a mais de seis meses no setor. Foram excluídos da pesquisa os profissionais que estavam de licença trabalhista no período de realização do estudo.

A coleta de dados iniciou após a aprovação do Comitê de Ética e Assinatura do Termo de Consentimento Livre e Esclarecido (TCLE) por meio de uma entrevista estruturada, que foi audiogravada. Os instrumentos utilizados para a realização da coleta da pesquisa foram um questionário estruturado e um checklist sobre o conhecimento dos enfermeiros acerca da gasometria. O prontuário do paciente foi consultado em caso de necessidade.

Para a realização da análise dos dados, foi realizada a transcrição e categorização das informações do questionário, com base na técnica de análise de conteúdo. Foi atribuído nomes de flores para preservar a identidade dos profissionais de saúde (Cerejeira, Cravo, Cravina, Crisântemo, Girassol, Lírio, Gloriosa, Iris, Jacinto, Tulipa e Ipê).

A pesquisa foi aprovada pelo Comitê de Ética de Pesquisa da Universidade Estadual do Ceará, aprovada sob o Parecer N 2.421 .753 e pelo Comitê de Ética de 
Pesquisa do HGF, sob o parecer $\mathrm{N}^{\circ}$ 2.452.106. Foram respeitados os preceitos éticolegais (autonomia, não maleficência, beneficência e justiça) recomendados na resolução $\mathrm{n}^{\circ} 466 / 12$ sobre pesquisas envolvendo seres humanos do Conselho Nacional de Saúde (BRASIL, 2013).

\section{Resultados e Discussão}

A Tabela 1 a seguir descreve os dados sociodemográficos dos profissionais que participaram do estudo. Observou-se que a maioria dos profissionais era do sexo feminino (91\%), com idade entre 38 a 58 anos (64\%), com o tempo de atuação entre 3 a 7 anos (64\%), sendo que a maior parte deles tinha cursado duas ou mais especializações (54\%).

Tabela 1 - Dados sociodemográficos dos profissionais

\begin{tabular}{l|c|c}
\hline \multicolumn{1}{c|}{ Características } & $\mathbf{N}^{\circ}$ & $\%$ \\
\hline Idade (anos) & & 36 \\
\hline 27 a 37 anos & 04 & 64 \\
38 a 58 anos & 07 & \\
\hline Sexo & 10 & 91 \\
\hline Feminino & 01 & 09 \\
Masculino & & \\
\hline Anos de Profissão & 07 & 64 \\
\hline 03 a 07 anos & 04 & 36 \\
Acima de 07 anos & & \\
\hline Especialização & 03 & 27 \\
\hline Não possui & 02 & 18 \\
Possui 01 & 06 & 55 \\
02 ou mais & & \\
\hline
\end{tabular}

Fonte: Elaboração dos autores (2018).

A partir da análise de conteúdo das entrevistas, emergiram três categorias: Cuidados de Enfermagem no Processo de Coleta da Gasometria; Cuidados de Enfermagem durante as Etapas da Coleta de Gasometria; Intervenção do Enfermeiro após a Coleta e Resultados da Amostra. 


\section{Cuidados de enfermagem no processo de coleta da gasometria}

Para fazer a coleta de gasometria é necessário conhecimento técnico científico e os cuidados de enfermagem necessários para a eficácia dos resultados, além da assistência adequada aos pacientes. Desta forma, esta categoria tem a finalidade analisar os cuidados essenciais de enfermagem na coleta da gasometria.

Analisados os dados das entrevistas, foram identificados vários aspectos importantes relacionados à prática do enfermeiro nas unidades de terapia intensiva do local da pesquisa. Os enfermeiros entrevistados trouxeram conhecimento acerca dos cuidados a serem observados durante o processo de coleta de material, alguns fragmentados, incompletos, mas todos traziam uma bagagem importante de saberes para executarem um cuidado de qualidade.

Crisântemo, 32 anos, solteira, 07 anos de formada, especialista em Urgência Emergência, cursando especialização em UTI, relatou durante a primeira pergunta, os seguintes cuidados:

Assepsia do local, a seringa tem que ter heparina, [...] agora eu não lembro de verdade quanto tempo tem que ficar pressionando em seguida, mas tem que fazer essa pressão, que o laboratório daqui não faz, deixa o paciente sangrando aí até umas horas (Crisântemo).

Cravina, 44 anos, casada, 04 anos de formação, pós-graduada em UTI e Saúde Pública, relatou sobre a importância do Teste de Allen, a escolha da artéria a ser puncionada e a pressão que deve ser exercida após a punção, pois ela proferiu que alguns profissionais do laboratório não realizam a compressão correta no local da punção, ocasionando assim um sangramento na região puncionada.

\footnotetext{
Os cuidados é saber a artéria correta, fazer aquele testezinho, que eu esqueci até o nome... Allen é pra poder pegar, saber se é arterial se é venosa, e o cuidado também de pressionar a artéria pra poder não sangrar, porque às vezes acontece, no caso não somos nós, mas tiveram pessoas do laboratório que veio colher, ai termina de colher vai embora, quando a gente dar fé, tá lá sangrando, então ter esse cuidado de puncionar né, para poder parar o sangramento e depois colocar um curativozinho, esse é um dos principais cuidados que eu acho (Cravina).
} 
Por se tratar de uma punção arterial, é imprescindível que o profissional responsável pela coleta da gasometria não deixe de realizar a compressão, pois existe uma pressão maior entre os vasos, diferentemente de uma punção venosa, que não necessita de uma pressão por um tempo maior (PINTO et al., 2016).

Cerejeira, 40 anos, solteira, formada há 07 anos, especialização em UTI e Urgência e Emergência, relatou não ter domínio sobre a gasometria, porém com os poucos conhecimentos que ela tem sobre o assunto, citou os seguintes cuidados: atenção sobre o local da gasometria, ou seja, a artéria escolhida, assepsia e compressão.

Certo, como eu te falei, eu não domino muito a gasometria, mas pelo pouco conhecimento que eu tenho é assim, com relação aos cuidados no processo da coleta, eu creio que seja é, você ver bem o local onde vai fazer o procedimento né, para não tá furando o paciente demais, palpar e realmente ter a certeza onde vai fazer aquela coleta, assepsia que é também muito importante e depois da coleta a compressão que é muito importante também né, tem que ficar comprimindo até ter aquela cascata de coagulação para não ter risco de o paciente ficar sangrando e fazer hematoma (Cerejeira).

Jacinto, 49 anos, casada, 06 anos de formada, pós-graduada em UTI e Saúde Pública, citou como principais cuidados o uso de equipamentos de proteção individual (EPI) e heparinização da seringa.

Usar luva de procedimento, gorro, máscara, EPI, agulha e seringa descartável, heparinizar pra evitar a coagulação, levar para o laboratório e trazer o resultado (Jacinto).

Íris, 27 anos, solteira, formada há 03 anos, cursando especialização em Unidade de Terapia Intensiva, citou que os principais cuidados que ao realizar a gasometria devem ser: Teste de Allen, heparinização da seringa, proteção dos êmbolos e acondicionamento do biológico.

[...] O adequado é a gente avaliar como é que tá esse pulso fazer os testes pra ver se após as punções vai ter sangue suficiente, o retorno para aquela extremidade. Na coleta ter cuidado com a questão da proteção dos êmbolos, a assepsia do local, bem como também a heparinização da seringa e o acondicionamento adequado, quando acolhido aqui pelo enfermeiro ou pelo interno a gente leva até o gasômetro para fazer a leitura (Iris). 
Em relação ao Teste de Allen, é de suma importância que todo paciente que seja submetido a realizar o exame de gasometria, faça o teste antes, pois este indicará se há uma circulação colateral positiva ou não (PINTO; SARACINI 2016). Dessa forma, o profissional que for colher a gasometria terá uma segurança maior sobre a artéria escolhida, pois caso a circulação colateral da mão do paciente for negativa, o profissional poderá partir para outra artéria, evitando assim danos ao paciente e mantendo a segurança dele.

Gloriosa, 42 anos, casada, 11 anos de formada, pós-graduada em Saúde do Trabalhador e UTI em andamento, relatou que por não ser uma prática dos profissionais enfermeiros colherem a gasometria, acabam negligenciando $o$ procedimento, mas, Gloriosa falou sobre alguns cuidados que deve ter ao realizar a coleta, como; assepsia, não contaminar o local, ter uma técnica própria, uso de EPI, teste de Allen entre outros que podem ser. Além disso ela cita as falhas cometidas pela equipe do laboratório, a começar pela falta de observação dos cuidados em relação aos pacientes em isolamento de contato, até a falha na compressão pós-punção arterial que não ocorre de forma eficaz.

\begin{abstract}
Assim como não é uma prática nossa aqui fazer coleta de gasometria, a gente acaba negligenciando e muito, eu sei que você tem que ter o cuidado de quando for fazer a coleta fazer uma assepsia boa, não contaminar o material, você fazer com uma técnica própria, usar seus EPIs que estiverem disponíveis, que você tem que fazer teste de Allen para ver perfusão, qual o braço melhor que você vai fazer a coleta, qual a radial, a gente tem muito problema com relação ao antes, na contaminação do material, o que acontece, abre todas as seringas joga em cima do paciente que é isolamento, pra depois botar lá, muitas vezes não levam nem algodão com álcool, clorexidina, na verdade tem que ser, muitas vezes só algodão seco e passa lá de qualquer forma e faz a coleta, tem muito problema nessa contaminação na coleta e na contaminação do material. Tem muito problema com relação ao pós, porque o pós você tem que fazer uma compressão, você tem que elevar esse braço um pouquinho, tem que ficar lá e muitas vezes ninguém fica, faz a compressão achou que trinta segundos, um minuto tá bom, larga esparadrapo muitas vezes não larga nada, deixa lá o paciente, ai quando a enfermeira vai olhar tá lá a poça de sangue, "meu Deus o que foi isso?". Questão mesmo de não ser rotina a gente não pega muito no pé [...] (Gloriosa).
\end{abstract}

O exame é um procedimento estéril onde o profissional deverá exercer seu conhecimento técnico-científico, a fim de evitar danos ao paciente. Todo material deve ser previamente preparado em uma bandeja limpa, onde o profissional levará até o 
paciente, sem haver necessidade de está expondo o material em cima da cama, pois caso isso aconteça, poderá estar possibilitando uma contaminação do material pelo próprio paciente ou ocasionando a entrada de ar dentro da seringa (SOLER; SAMPAIO et al., 2012).

Ipê, 54 anos, divorciada, 30 anos de formada, especialista em Psicologia Hospitalar e Obstetrícia chamou a atenção sobre seguintes cuidados: escolher uma artéria que não seja de grosso calibre inicialmente, a compressão que deve ser estabelecida e assim como outros profissionais, Ipê relatou a não realização correta da compressão pelos profissionais do laboratório, responsável pela coleta nos pacientes.

Preferir uma artéria que não seja de tão grosso calibre, evitar sempre a femoral, porque a femoral ele é numa região, pela proximidade com a região inguinal, ou com a região genital né? Com a região anal é um local assim que tem probabilidade de tá contaminado, tá infectado, então a gente evita a femoral, a gente prefere mais a radial, a gente não usa nem tanto a braquial, sempre a radial e assim de preferência que seja que seja uma furada, porque assim, eu detesto tá manipulando demais os pacientes, é dolorido, todos os pacientes assim quando estão conscientes, que são puncionado a artéria eles falam que é uma dor horrível, que é como se tivessem furando o osso. [...] Não é porque o paciente tá em coma que ele não está sentindo, ele sente tudo! Então esse tem que ter, evitar, é ter que limpar, puncionar, segurar por 5 minutos aquela artéria, evitar que haja extravasamento pros tecidos, a gente ver assim umas punçoes que ficam um hematoma enorme, ou a pessoa só punciona, não tem a paciência de ficar segurando, e ai só coloca um, segura um pouquinho, não passa 1 minuto e bota um algodão, bota um esparadrapo e não adianta de nada, não estou falando enfermeiro, estou falando de alguns coletores do laboratório, saem e quando a gente olha está cheio de sangue na mão do paciente todos esses cuidados são importantes né? Você tem que prevenir não remediar! (Ipê).

A escolha da artéria tem um fator preponderante em relação a cada paciente, inicialmente a artéria de melhor escolha deve ser a radial, por se tratar de uma artéria relativamente superficial e com uma pressão menor do que as demais. Logo em seguida vem a braquial e por último a femoral. Esses cuidados devem ser respeitados, levando em consideração a redução de danos ao paciente (SOCIEDADE BRASILEIRA DE PATOLOGIA CLÍNICA/MEDICINA LABORATORIAL, 2014).

Caso a artéria radial esteja imprópria para a punção, o profissional deverá avaliar o paciente em relação ao seu quadro clínico, saber se faz uso de algum anticoagulante, pois caso o paciente tenha algum distúrbio de coagulação, o profissional terá que ter uma atenção maior à colher o exame. Além disso, terá que 
prestar cuidados maiores em relação ao tempo de compressão sobre aquela artéria puncionada (PINTO et al., 2017).

Segundo a Sociedade Brasileira de Patologia Clínica e Medicina Laboratorial (SBPCML), deve-se se a artéria a ser puncionada apresenta um calibre bom e superficial, além da presença de circulação colateral, para que, em caso de espasmo ou formação de coágulo, o membro não tenha o fluxo sanguíneo interrompido. A artéria radial atende a esses critérios, sendo assim, habitualmente o local de escolha para a punção arterial (SOCIEDADE BRASILEIRA DE PATOLOGIA CLÍNICA/MEDICINA LABORATORIAL, 2014).

Tulipa, 36 anos, 07 anos de formada, especialista em UTI Intensiva e Mestrado em Cuidados Clínicos, relatou também a questão dos enfermeiros não serem os responsáveis pela coleta, e sim responsabilidade do laboratório. Porém descreveu alguns cuidados caso fosse colher, como por exemplo; higienização, preparo da seringa, estado do paciente e compressão.

Tulipa citou exemplos de algumas situações que já ocorreram durante a coleta da gasometria pelos profissionais do laboratório, ela conta que hoje nem tanto, mas antes eles faziam a punção e que por falta de tempo e devido ao grande número de pacientes que eles tinham que realizar a coleta, eles acabavam não fazendo a compressão por um tempo adequado para parar o sangramento. Então já colocavam um "tufinho" de algodão com esparadrapo naquele membro, fazendo assim um curativo compressivo, pois eles não teriam tempo de ficar esperando o sangramento parar. Porém às vezes a pressão exercida nesse curativo era tão forte, ao ponto de garrotear o membro do paciente, prejudicando uma circulação sanguínea adequada para aquela região. Ou então era ao contrário, faziam o curativo e ele logo se soltava e o paciente ficava sangrando.

Primeira coisa é que aqui a rotina é do laboratório, como são eles que fazem, eles colhem todos os dias o sangue arterial e desse sangue eles utilizam para fazer todos os outros exames, então muitas vezes o enfermeiro que detecta que não há necessidade de ser arterial, [...] O segundo eu acho que a higienização das mãos, não sei se é bem isso que você quer saber, e o preparo da seringa de tá heparinizada, está atento ao estado do paciente, do que ele vai sinalizar pra você, está atenta ao estado do paciente que responde a dor né? [...] mas eu acho que a limpeza e também quando você termina a coleta, você comprimir o local né, até que realmente o paciente pare de sangrar, 
porque é importante até um curativozinho compressivo e sinalizar a equipe também para [...] poder tirar esse curativo, porque o que acontece muito aqui, no laboratório, é que eles vêm, eles fazem a coleta, hoje não, mas acontecia muito e depois de muitas reclamações eles tomaram mais cuidados. É, eles faziam a coleta e não esperavam aquele tempo necessário que eu esqueci, acho que é de 03 a 05 minutos, não sei se é o suficiente, mas eles não queriam esperar esse tempinho devido ao grande número de coleta e eles já colocam aquele tufinho de gaze com esparadrapo e às vezes garroteava o braço do paciente, quando a gente ia ver, estava lá garroteado, sem necessidade, ou ao contrário, não colocava a pressão suficiente, a compressão do curativo e saia, e o paciente ia perdendo sangue, então eu acho que esse é um dos cuidados que também devemos ter limpeza, se atentar ao paciente e o pós também (Tulipa).

Lírio, 46 anos, casada, formada há 10 anos, com especialização em Unidade de Terapia em Andamento, relata sobre a questão de evitar prejuízos ao paciente, realizar rodízio dos membros. A profissional explica que geralmente os responsáveis pela coleta, costumam fazer a punção sempre no mesmo lugar, por já conheceram a região puncionada anteriormente, sendo que essa conduta pode acarretar um problema maior ao paciente, que já estar em busca de uma melhoria do seu quadro clínico.

Favarin e Camponogora (2012) afirmam que o enfermeiro que trabalha com cuidados intensivos deve-se manter voltado a uma série de competências, entre elas sinais vitais, equilíbrio hídrico, controle e administração do uso de drogas vasopressoras, antibioticoterapia, coleta adequada e acompanhamento à análise de materiais biológicos (gasometria) para exames laboratoriais, realização de uma avaliação aprimorada do nível de consciência, entre outros cuidados que o paciente de UTI necessita.

Todo profissional deve ter uma visão ampliada em relação às iatrogenias que podem atingir o paciente em relação a qualquer ato realizado sobre ele.

Então tá, primeiro a gente avalia o membro, porque como a coleta em UTI é diária, tem que ter o teste de Allen, coisa que você não vê fazer, principalmente aqui no hospital, é coletado pelo pessoal do laboratório, muitas vezes quando a gente vê, eles já coletaram, quando eu vejo coletando durante o dia, eu procuro ir até eles e ajudar e orientar, porque eles têm mania de colher sempre no mesmo lugar, porque é mais fácil, porque já colheu ali, então a gente procura rodiziar os membros, muitas vezes a gente até coloca 
placas nas camas "não colher do membro tal" pra evitar o uso abusivo daquele membro pra evitar trombo, hematoma, tudo isso para que eles usem outro membro para a coleta do paciente, evitando assim prejuízo maior ao paciente (Lírio)

Apesar de já observarem melhora no cuidado com a coleta, quase todos os entrevistados citaram as falhas dos coletadores da gasometria arterial em relação à pós punção arterial, que não fazem a compressão por $5 \mathrm{~min}$, acarretando aos pacientes sangramento e/ou membros garroteados se necessidade.

Diante das falas pode-se perceber a necessidade de um olhar mais atento do enfermeiro no tocante à supervisão do técnico de enfermagem e/ou técnico de laboratório no momento da coleta, bem como no momento após a punção. Dessa forma, o profissional enfermeiro consegue minimizar os riscos de eventos adversos advindos do procedimento.

\section{Etapas da gasometria}

Assim como todo procedimento, a gasometria também tem suas etapas para ser desempenhado, o profissional necessita de conhecimento para percorrer todas essas fases, garantindo uma prática segura, diminuindo a possibilidade de provocar danos ao paciente, desde a solicitação até o resultado.

É importante a visão do enfermeiro em relação situação clínica do paciente, pois existem fatores que podem interferir no resultado e na prática da coleta da gasometria.

Quanto aos cuidados pré, trans e pós procedimento, Crisântemo citou a Assepsia, posicionamento da agulha, compressão, quantidade de heparina, bolinha de algodão na seringa e o tempo.

A questão da assepsia do local, a questão da agulha, isso é o pré. Posicionamento da agulha também entra durante o trans e a compressão com uma bolinha de algodão, e o pós a questão do transporte, não pode ter bolhinhas de ar na seringa, cuidado com a quantidade de heparina e o tempo né, até chegar ao gasômetro (Crisântemo). 
Já Cravina cita a pressão no local da punção e cuidado em relação ao tempo, ou seja, levar de imediato o biológico ao gasômetro.

É eu acho que os cuidados são assim que colher também fazer a punção, o cuidado é de imediato ir ao gasômetro pra poder não ter alteração, porque às vezes também se demorar, pode coagular e botar o exame a perder, acho que o cuidado tanto no pré, como no trans e pós mais é esse, é o tempo, o cuidado no tempo de colher o sangue e poder fazer a análise (Cravina).

Iris leva em consideração o preparo do material, proteção dos êmbolos, seringa heparinizada, homogeneização do biológico, proteção da seringa até chegar ao gasômetro e a compressão que deve ser estabelecida no local da punção.

Ressalta-se que já existem seringas distintas para coleta de gasometria, as quais já vêm preparadas com heparina de lítio, na quantidade adequada, com balanceamento de cálcio, evitando uma série de distorções que podem ser observadas com o uso da heparina líquida (SOCIEDADE BRASILEIRA DE PATOLOGIA CLÍNICA/MEDICINA LABORATORIAL, 2014).

\footnotetext{
No pré a gente prepara previamente lá na medicação a gente prepara direitinhos as seringas que vão ser utilizadas e os êmbolos devidamente protegidos, principalmente a seringa que tá heparinizada, a gente vai coletar e vai encaminhar a amostra até o gasômetro e após a coleta, homegeneizar a solução, proteger devidamente para poder levar até o gasômetro e também ter o cuidado em questão de como é uma punção arterial, comprimir, fazer um curativo adequado de forma que também a gente venha depois observar se a compressão não está garroteando o membro do paciente e levar até o gasômetro pra poder fazer a leitura de forma segura (Iris).
}

Jacinto citou alguns cuidados como: Repouso no leito, alimentação, dieta, preparar o paciente psicologicamente, orientar a ele que vai doer e realizar a compressão após a coleta. Tais cuidados não interferem no resultado da amostra, esses cuidados estão mais voltados para o processo cirúrgico ou outros exames.

Gloriosa relatou sobre a heparina, existem seringas que já vêm prontas, com a dosagem certa de heparina de lítio, diferentemente da heparina de sódio utilizada quando não tem se tem seringas próprias para coleta de gasometria.

De acordo com a Sociedade Brasileira de Patologia Clínica/Medicina Laboratorial (2014), o uso de seringa de preparação caseira, para a coleta da gasometria arterial, utilizando heparina líquida, não é indicado em razão das seguintes influências 
nos resultados: A heparina líquida em excesso pode causar diluição da amostra, resultando em valores incompatíveis com a situação clínica do paciente; a heparina de sódio pode elevar os níveis de sódio na amostra ao redor de 1 a $3 \mathrm{mEq} / \mathrm{L}$, mesmo coletando o volume máximo de preenchimento da seringa; a heparina líquida aumenta a possibilidade de interferência na dosagem de cálcio iônico, pois a heparina liga-se quimicamente ao cálcio, resultando em valores falsamente mais baixos; a introdução do cálcio em concentração balanceada nas seringas destinadas especificamente para coleta de gasometria e eletrólitos tem a finalidade de minimizar os efeitos da queda deste íon na amostra; a elevada concentração de heparina pode alterar o $\mathrm{pH}$ da amostra e, por consequência, o resultado de cálcio ionizado, que também sofre variações dependendo do $\mathrm{pH}$ da amostra; a heparina líquida pode também induzir alterações no nível de magnésio iônico, embora em menor intensidade quando comparada à dosagem do cálcio ionizado.

As seringas não específicas para a análise de gases sanguíneos, além de poderem causar um risco de diluição da amostra, podem ocasionar formação de micro coágulos por ter uma quantidade insuficiente dentro da seringa, podendo produzir resultados errôneos, bem como obstruir os equipamentos analisadores de gases sanguíneos (SOCIEDADE BRASILEIRA DE PATOLOGIA CLÍNICA/MEDICINA LABORATORIAL, 2014).

Gloriosa relata que não se tem seringas apropriadas e que observa os coletores colocando cerca de $1 \mathrm{ml}$ de heparina e ela frequentemente corrige os colegas, afirmando que não necessita dessa quantidade de heparina. Ela relata, quanto ao uso do gasômetro, que considera fácil, autoexplicativo, que muitas vezes o "não saber usar" passa pela falta de interesse de ler o que o aparelho vai orientando.

Para Ipê os cuidados relacionados ao pré, trans e pós devem ser: não deixar ar dentro da seringa, realizar a punção de forma correta em questão de puncionar mesmo uma artéria, não deixar o sangue coagular. Com isso, o profissional terá que ir homogeneizando a amostra de forma correta, limpar o receptor do gasômetro antes de inserir a seringa no mesmo, pois algum resto de outra amostra pode interferir no resultado e por último fala em questão da quantidade de sangue aspirado, para que 
não seja uma quantidade insuficiente e que o leitor não consiga analisar o sangue corretamente.

A quantidade de sangue que o profissional aspira tem um significado muito importante tanto para a análise como para o paciente, pois se o profissional responsável pela coleta colhe uma amostra insuficiente, ele terá que realizar outra punção no paciente, que lhe causará mais dor, poderá também desencadear um possível estresse ao paciente, pois a punção é muito dolorida.

O profissional estará também aumentando o risco de contaminação por se tratar de um procedimento invasivo, quanto mais manipulado esse paciente for, maior será a chance de ele contrair uma infecção (BARBOSA et al., 2014).

É bom que não fique ar dentro da seringa, tem que ter a certeza que você
puncionou sim uma artéria e não uma veia, você observa, você observa que o
sangue arterial ele é mais claro que o sangue venoso, o sangue venoso ele é
mais escurecido, mas às vezes tem paciente tão grave, tão grave, que você fica
na dúvida, ai só com o resultado da gasometria que você ver que realmente
aquele sangue não era venoso, era arterial, e assim uma coisa que a gente tem
que ter muito cuidado é não deixar aquele sangue coagular né? E ir
homogeneizando até chegar lá no gasômetro, limpar antes da inserção, você
tem que limpar o receptorzinho do gasômetro né? Após a inserção também
você tem que limpar e assim, assim como eu já falei observar se não teve ar, e
também ver o tanto de sangue que você aspirou para que não seja insuficiente
e que você não tenha que perfurar de novo o paciente (Ipê).

No resultado da amostra né, a heparinização correta né, que muitas vezes a gente faz só, como chama assim né "sujar a seringa de heparina", é me deixar ver, retirar o ar da seringa, deixar ela, que as vezes a gente deixa uma aberturinha aí já pode interferir, explicar o paciente, mas acho que isso não interfere na amostra. $\mathrm{O}$ trans, é observar se realmente o sangue é arterial ou venoso, é importante, da pra ver pela cor e trans, trans acho que vai influenciar na amostra, é isso. Que como a gente não faz eu não sei realmente! O pós, o cuidado, não influencia na amostra, mas levar imediatamente para o gasômetro, mas é isso, como eu não faço, eu não sei! (Tulipa).

[...] Preparo do material da observação do membro a ser coletado, o transporte, procurar ser o mais rápido possível, para ser fidedigno o resultado e quanto ao sangramento né, fazer bastante compressão né, e depois o curativozinho e deixar o membro assim, meio que exposto em cima do lençol pra você tá observando, porque às vezes você acha que parou de sangrar ai vira as costas, quando volta o paciente tá "mergulhado em sangue", então coletou gaso, você tem que esse cuidado de tá na observação do membro, principalmente esses pacientes tem muito distúrbio de coagulação, então neles que a gente tem que ficar mais atento (Lírio).

O pessoal do laboratório vem e colhe radial ou venoso ou arterial, conforme a solicitação do médico aspira $03 \mathrm{ml}$, ele tem que levar o mais rápido possível para que os gases não se disseminem e no momento da aspiração não haver 
bolhas porque também altera o resultado final, evitar ter bolhas no sistema na aspiração e também não demorar a levar o sangue para interpretação dos gases na máquina. E pós se tiver com alguma alteração acidose ou alcalose, fazer medicações EV, ou se tiver intubado nós alteramos os modos ventilatórios, se for pulmonar, se for metabólica é com drogas (Cravo).

Tulipa, Lírio e Cravo, relataram praticamente os mesmos cuidados que Ipê, porém eles acrescentam a preocupação em realizar a compressão e em levar o sangue o mais rápido possível ao gasômetro, pois quanto mais demorar a ser analisado, menos fidedigno ele pode ser, o ideal é que ele seja analisado em até 15 minutos.

\section{A intervenção do enfermeiro perante o resultado}

A terceira pergunta, foi relacionada ao resultado da gasometria, em que foi indagado aos profissionais se eles tomavam alguma decisão perante o resultado, com o intuito de descobrir se havia uma troca de conhecimentos entre a equipe Multiprofissional e se o Enfermeiro que deve ser o responsável pela coleta da gasometria, saberia agir de forma proativa a fim de diminuir danos ao paciente e elevar o nível de sobrevida do mesmo, já que os distúrbios ácido-base podem levar o paciente a coma e até a morte.

Os profissionais entrevistados trazem relatos de que há uma rotina estabelecida em que a equipe médica e de fisioterapeutas assumem a checagem dos resultados da gasometria, bem como as condutas a serem tomadas. Relatam ainda que a comunicação com o enfermeiro em relação à gasometria dos doentes é ineficaz, pouco ou nunca comunicam as alterações.

A visita multiprofissional é como se fosse o único momento em que essas alterações são repassadas para toda a equipe, e o momento em que o enfermeiro toma conhecimento acerca da gasometria. Os resultados ficam disponíveis no sistema informatizado para checagem de todos os profissionais, bem como o impresso vem para a unidade, o enfermeiro tem acesso, mas segundo os relatos, eles não têm o hábito de checar o exame em questão.

Crisântemo relata que há uma visita multidisciplinar, e que é passado o quadro do paciente para os outros profissionais em relação à gasometria. 
No caso aqui, o gasômetro é direto na mão do residente, não, mas aqui todos os dias passa a visita multidisciplinar e na visita é passado, porque todas as condutas que o médico e o residente querem tomar em ralação ao paciente, a fisioterapia também com relação em questão da ventilação, eles têm que ter a gasometria, e é de acordo com a gasometria também (Crisântemo).

Já Cravina, não cita a visita multiprofissional como momento importante para as tomadas de decisões no tocante à gasometria, como Crisântemo falou anteriormente. Cravina relata que a gasometria fica somente entre o profissional médico e o fisioterapeuta, que não há uma relação com o enfermeiro em questão do resultado, médico e fisioterapeuta avaliam e tomam as condutas cabíveis.

Pinto et al. (2017) corroboram que o enfermeiro tem uma capacidade de explorar a gasometria arterial, relacionando ao quadro clínico do paciente, é uma tarefa importante do enfermeiro, pois ele possui um olhar holístico ao paciente em relação a sua oxigenação, ventilação e estado ácido-básico.

Não, porque essa parte ai não somos nós! Geralmente, aqui só quem usa a gasometria, que avalia é o médico e o fisioterapeuta, então assim, o médico sempre discute com o fisioterapeuta, ele que vai ver os parâmetros, dependendo do resultado da gasometria né, o que deu se foi acidose, se foi metabólica, se foi acidose respiratória, então assim, os resultados pra reajustar parâmetros no ventilador essas coisas tudo, é dependendo o médico que decide e passa para o fisioterapeuta, ele não fala com a gente (Cravina).

Jacinto também relata que fica tudo entre o médico e o fisioterapeuta.

Não é com o enfermeiro, o procedimento é médico, totalmente médico, essa parte fica com o fisioterapeuta. (Jacinto)

Iris fala que é uma questão de logística de trabalho, e não falta de conhecimento, que as alterações ficam a comando do médico e fisioterapeuta, sendo que as questões respiratórias ficam voltadas para o fisioterapeuta. O médico avalia a questão dos eletrólitos se há necessidade de uma reposição. Conclui enfatizando que é por uma logística de trabalho e que os enfermeiros têm o conhecimento sobre os distúrbios ácido-base. 
Bom, aqui normalmente a análise da gasometria, não por falta de conhecimento, mas pela logística mesmo para a utilização do trabalho, eles fazem alterações entre fisioterapeuta e médico, alteração de, é mais pra fisioterapia essa parte quando é alteração respiratória né, o manuseio com o ventilador normalmente é feito pelo próprio fisioterapeuta, mas o médico tá ali também sempre avaliando a questão dos eletrólitos as reposições, nós enfermeiros temos o conhecimento sobre as alterações metabólicas os distúrbios acido-básico, eletrolítico, mas a gente não trabalha assim voltada para a análise da gasometria, mas a gente tem conhecimento! (Iris).

Cerejeira começa relatando que ao chegar à gasometria o correto é comunicar ao médico, que ele saberá a conduta a ser tomada, porém de acordo com as respostas de alguns profissionais, eu a indaguei se ela mesma comunicava. Ela me respondeu que a gasometria não era um procedimento muito restrito ao enfermeiro, que eles não tinham acesso ao resultado; o resultado vem de forma informatizada (sistema), mas que também tem o resultado impresso.

Completa a sua fala sobre o conhecimento em analisar a gasometria, caso o enfermeiro tenha, ele pode sinalizar para o médico e discutir os resultados para posteriormente ter as condutas aplicadas. Enfatiza que se o enfermeiro tiver o conhecimento fica mais fácil de questionar e de ter alguma conduta perante o resultado.

Verifica-se, a imprescindibilidade do enfermeiro estar sempre procurando novos conhecimentos para o aperfeiçoamento da sua prática, no aspecto da coleta, interpretação de exames e preparação das ações voltadas para estabelecer uma continuidade do cuidado sobre a homeostase do paciente instável (PINTO et al., 2017).

Depois que chega o resultado, é comunicar o médico né? Aliás, ele já vai saber a conduta a ser tomada, se for algum tipo de acidose, se for respiratória vai ter que mudar os parâmetros no ventilador e se for metabólica, vai ter que entrar com medicação, isso junto com o plantonista, a gente sinaliza para o médico e ele vai dizer às condutas que a gente deve tomar. (PERGUNTEI SE ELES MESMOS COMUNICAVAM). Assim, é no caso se a gente [...] É no caso se a gente, porque como a gasometria, assim por enquanto ainda não tá muito restrito ao enfermeiro né, aqui quem coleta é o laboratório, a gente não tem acesso ao resultado, é no sistema, mas eles trazem aquele papelotezinho e o médico vê, se a gente quando entende do resultado, você pode sinalizar para o médico, discutir e ele vai tomar a conduta necessária né, é bom que a gente sempre tenha o conhecimento pra você saber como sinalizar, e se você tiver o conhecimento fica mais fácil de questionar né, e fica até mais fácil de tomar uma conduta (Cerejeira). 
O enfermeiro responsável pelo cuidado de pacientes críticos tem o seu papel importante em saber avaliar os resultados de uma gasometria, e discutir com o restante da equipe multiprofissional dentro da UTI, pois assim como ou outros profissionais, o enfermeiro também necessita do saber agir para saber fazer, ou seja, o enfermeiro anda lado-a-lado com a proatividade, a fim de diminuir danos ao paciente (BARBOSA et al., 2014).

Gloriosa relata que normalmente quando o resultado chega, só há uma informação perante o resultado "Doutor, chegou à gasometria" somente isso. Porém ela tem consciência que não deve ser dessa forma, e que ela sabe reconhecer se o paciente está com alguma alteração, que acha necessário que pelo menos o enfermeiro saiba identificar o que é normal pelo menos.

Contudo completa sua fala, dizendo que na maioria das vezes só há essa comunicação entre o enfermeiro e o médico.

Ipê também afirma que o resultado da gasometria fica somente na responsabilidade do médico e fisioterapeuta, e que eles dependem do que o médico decidir.

Contudo, Ipê considera um erro do enfermeiro não se ater aos resultados, que mesmo o enfermeiro tendo uma série de afazeres ele tem que ter o conhecimento, pois pode acontecer de uma hora não ter nem o médico nem o fisioterapeuta no setor, e se o enfermeiro que pegar o resultado e souber reconhecer alguma alteração, ele pode correr e chamar o médico para analisar uma conduta a ser realizada em benefício do paciente. Dessa forma Ipê relata que os enfermeiros estão sendo falhos nessa perspectiva da análise da gasometria.

É fundamental a atuação do enfermeiro nos debates sobre a instabilidade do paciente, podendo assim ele vir intervir, discutindo sobre os parâmetros da ventilação mecânica após a análise da GA. Essas ações devem ser promovidas e encorajadas pelas instituições hospitalares, possibilitando maior espaço de atuação e liberdade para o enfermeiro intervir de acordo com suas habilidades e competências com o conhecimento técnico-científico. 
Bem assim quando o enfermeiro identifica acidose ou alcalose né? Já passa para o médico e ele já vai tomar, ele que diz o que tem que ser feito, fala com o fisioterapeuta se vai fazer alguma alteração na ventilação, se ele vai repor o bicarbonato, o que ele vai fazer. Então assim, aqui mesmo na UTI, a gente depende do que o médico decidir, a gente não toma nenhuma conduta, sem, mas geralmente quem pega o resultado da gasometria são os fisioterapeutas ou médicos, inclusive a gente tem até uma prancheta reservada só para gasometria. Ai eles dois são quem avaliam o enfermeiro geralmente não se atém a essa parte de tá analisando resultado da gasometria, que é um erro né? Mas assim, é tanta coisa já Jennifer, assim isso, há, mas pode dizer, há, mas não justifica, porque o enfermeiro tem muito que fazer e deixar de ver, a gente tem que ver! Por que assim o enfermeiro tem obrigação de saber tudo, porque assim o que eu penso assim, uma hora determinada hora não tem o médico nem o fisioterapeuta ali, então você tem que analisar e já correr, [...] tipo aqui a gente, um enfermeiro fica com 05 pacientes e o enfermeiro aqui é assistencial, fora essa parte da burocracia, nós somos assistenciais e então assim, é um mundo! E tudo que é inovação, tudo que é mudança sempre gera uma responsabilidade para o enfermeiro, mas nós estamos falhos nisso! (Ipê).

Lírio afirma que muitas vezes o resultado da gasometria acaba nem chegando a eles, por terem outros profissionais, como médicos, fisioterapeutas, residentes e internos a gasometria fica entre eles. Lírio fala que a participação do enfermeiro em relação à gasometria é na administração de medicamentos, caso o paciente se encontre acidótico, outro profissional chega e pede para fazer a administração de algum medicamento. Ou seja, a participação do enfermeiro se detém a isso.

É importante a participação do enfermeiro nas discussões clínicas sobre as alterações de parâmetros do ventilador mecânico após a interpretação da GA, e essa participação deve ser incentivada pelas instituições hospitalares, dando maior liberdade para a intervenção do enfermeiro (ROLIM., 2013).

\section{Considerações Finais}

Pelo exposto trabalho, conclui-se que há um distanciamento dos enfermeiros em relação ao conhecimento completo dos processos que envolvem a gasometria, pois de acordo com os relatos, muitos afirmaram não ter domínio em razão de não ser uma rotina deles no setor em que atuam.

Os enfermeiros acabam deixando tanto o procedimento, como a interpretação da gasometria de lado, sendo que a agilidade na interpretação e 
intervenção pode ajudar e muito os pacientes, pois os distúrbios ácido-básico podem levá-lo ao coma e até mesmo a morte.

É possível perceber que as atividades desempenhadas pelos enfermeiros que atuam em UTI são muitas e envolvem diversos aspectos, sendo relatado por eles que muitas vezes se sentem sobrecarregados devido à gravidade dos doentes e da quantidade de procedimentos e condutas a serem realizados durante os plantões. Entende-se, assim, que o desinteresse pela gasometria dos pacientes pode estar relacionado com a forma como se sentem em suas rotinas em relação a sobrecarga.

Sendo a gasometria um procedimento de rotina dentro das Unidades de Terapia Intensiva, o enfermeiro deve apropriar-se desse procedimento, pois ele é responsável por vários procedimentos de alta complexidade e, por executar seu trabalho intensivo junto ao paciente, consegue garantir maior segurança para a realização da gasometria do que quando realizada por outros profissionais que não permanece dentro da unidade como os profissionais do laboratório.

Para isso, o enfermeiro deverá estar dotado dos conhecimentos, competências e habilidades que garantam rigor técnico-científico ao procedimento, devendo passar por capacitações continuamente em relação à gasometria, no tocante as boas práticas para que desenvolva cada vez mais um procedimento seguro ao paciente, livrando o mesmo de danos. 


\section{Referências}

ANDRIOLO, Adagmar et al. (org.). Recomendações da Sociedade Brasileira de Patologia Clínica/ Medicina Laboratorial (SBPC/ML). Barueri: Manole: Minha Editora, 2014.

ARAUJO, Grabiela Machado de et al. Procedimento de gasometria arterial em unidade de terapia intensiva: relato de experiência. Revista de Enfermagem, v. 11, n. 11, p. 6371, 2015.

BARBOSA, Taís Pagliuco et al. Práticas assistenciais para segurança do paciente em unidade de terapia intensiva. Acta Paulista de Enfermagem, São José do Rio Preto, v. 27, n. 3, p. 243-248, 2014.

BRASIL. Lei $n^{\circ}$ 7.498, de 25 de junho de 1986. Dispõe sobre a regulamentação do exercício de enfermagem e dá outras providências. Diário Oficial [da] República Federativa do Brasil: seção 1, Brasília, DF, 26 jun. 1986. Disponível em: http://www.cofen.gov.br/lei-n-749886-de-25-de-junho-de-1986_4161.html. Acesso em: 21 jul. 2017.

BRASIL. Ministério da Saúde. Rede Nacional de Pesquisa Clínica. [Brasília, DF]: Ministério da Saúde, [20--]. Acesso em: 21 jul. 2017. Disponível em:

http://bvsms.saude.gov.br/bvs/folder/rede_nacional_pesquisa_clinica.pdf. Acesso em: 13 set. 2021.

BRASIL. Portaria n 529, de 1 de abril de 2013. Institui o Programa Nacional de Segurança do Paciente (PNSP). Diário Oficial [da] República Federativa do Brasil: seção 1, Brasília, DF, p. 43, 2 abr. 2013. Disponível em:

http://bvsms.saude.gov.br/bvs/saudelegis/gm/2013/prt0529_01_04_2013.html. Acesso em: 25 jul. 2017.

BRASIL. Resolução COFEN n 390/2011. Normatiza a execução pelo enfermeiro da punção arterial tanto para fins de gasometria como para monitorização da pressão invasiva. Diário Oficial [da] República Federativa do Brasil: seção 1, Brasília, DF, n. 202, p. 146, 20 out. 2011. Disponível em: http://www.cofen.gov.br/resoluo-cofen-n3902011_8037.html. Acesso em: 25 jul. 2017.

BRASIL. Resolução n ${ }^{\circ}$ 466, de 12 de dezembro de 2012. Diretrizes e Normas Regulamentadoras de Pesquisas Envolvendo Seres Humanos. Diário Oficial da União: seção 1, Brasília, DF, 13 jun. 2013.

BRASIL. Resolução n 7, de 24 de fevereiro de 2010. Diário Oficial [da] República Federativa do Brasil: seção 1, Brasília, DF, p. 48, 25 fev. 2010. Disponível em: http://bvsms.saude.gov.br/bvs/saudelegis/anvisa/2010/res0007_24_02_2010.htm 1. Acesso em: 21 jul. 2017. 
EXAME: gasometria arterial e os cuidados de enfermagem. [S.l.]: Enfermagem Novidade, 2015. Acesso em: 15 jul. 2017. Disponível em:

http://www.enfermagemnovidade.com.br/2015/05/exame-gasometria-arterial-eos-cuidados.html. Acesso em: 20 set. 2021.

FAVARIN, Simone Spiazzi; CAMPONOGARA, Silviamar. Perfil dos pacientes internados na unidade de terapia intensiva adulto de um hospital universitário. Revista de Enfermagem da UFSM, v. 2, n. 2, p. 320-329, 2012.

FLOR, Janaína da Silva; VARGAS, Mara Ambrosina de Oliveira. Adequação da prática de coleta de gasometria arterial pela enfermagem em unidade de terapia intensiva adulto. 2012. 11 f. Trabalho de Conclusão de Curso (Especialização em Enfermagem em Terapia Intensiva) - Universidade do Vale do Rio dos Sinos, 2012.

FURONI, Renato Marinho et al. Distúrbios do equilíbrio ácido- básico. Revista da Faculdade de Ciências Médicas, Sorocaba, v. 12, n. 1, p. 5-12, 2010.

MINAYO, Maria Cecília de Souza. Pesquisa social: teoria, método e criatividade. Petrópolis: Vozes, 2002.

MOTA, Igor Larchert et al. Análise dos diagnósticos hemogasométricos nas unidades de terapia intensiva. Revista de Enfermagem UFPE On Line, Recife, v. 7, n. 11, p. 6498-6504, nov. 2013. Disponível em:

https://periodicos.ufpe.br/revistas/revistaenfermagem/article/view/12297/14969. Acesso em: 13 set. 2021.

OLIVEIRA, Elias Barbosa de; SOUZA, Natalia Victor Madeira de. Estresse e inovação tecnológica em unidade de terapia intensiva de cardiologia: tecnologia dura. Revista de Enfermagem da UERJ, Rio de Janeiro, v. 20, n. 4, p. 457-462, out. / dez. 2012.

PINTO, Jéssica Mayara Alves et al. Gasometria arterial: aplicações e implicações para a enfermagem. Revista Amazônia Science \& Health, v. 5, n. 2, p. 33-39, abr./jun. 2017.

ROLIM, Luciana Ramalho et al. Conhecimento do enfermeiro de unidade de terapia intensiva sobre gasometria arterial. Revista de Enfermagem UFPE On Line, Recife, v. 7, n. 1, p. 713-721, mar. 2013. Disponível em:

https://periodicos.ufpe.br/revistas/revistaenfermagem/article/view/10284. Acesso em: 13 set. 2021.

SANDERSON, Leticia Godoy Dias. Gasometria arterial. 2012. 7 f. Trabalho de Conclusão de Curso. Porto Ferreira, 2012. 
SOCIEDADE BRASILEIRA DE PATOLOGIA CLÍNICA/MEDICINA LABORATORIAL. Recomendações da Sociedade Brasileira de Patologia

Clínica/Medicina Laboratorial (SBPC/ML): coleta e preparo da amostra biológica. Barueri: Manole: Minha Editora, 2014. Disponível em:

http://www.sbpc.org.br/upload/conteudo/livro_coleta_biologica2013.pdf. Acesso em: 24 set. 2021.

SOLER, Virtude Maria; SAMPAIO, Regiane; GOMES, Maria do Rosário. Gasometria arterial-evidências para o cuidado de enfermagem. CuidArte Enfermagem, v. 6, n. 2, p. 78-85, jul./dez. 2012.

TAVARES, Vânia Hilário. Segurança do paciente em terapia intensiva: análise de uso da restrição física. 2013. 129 f. Dissertação (Mestrado em Enfermagem) Universidade de Brasília, Brasília, DF, 2013. 


\section{5}

Corpo feminino e sua relação com os modos de cuidar de si:Análise estética na perspectiva de mulheres praticantes de crossfit 


\title{
15 CORPO FEMININO E SUA RELAÇÃO COM OS MODOS DE CUIDAR DE SI: ANÁLISE ESTÉTICA NA PERSPECTIVA DE MULHERES PRATICANTES DE CROSSFIT
}

\author{
Ticyane Candeia Ribeiro Sousa Olimpio \\ Daniele Vasconcelos Fernandes Vieira \\ Marcélid Berto da Costa \\ Francisco Régis da Silva \\ Ana Paula da Silva Morais
}

\section{Resumo}

Compreender os cuidados com a saúde feminina e as complexidades associadas também a prática do Crossfit se faz necessário considerando, portanto, as individualidades femininas (estética, beleza, saúde da mulher, práticas físicas) e todos os determinantes sociais que contextualizam essa temática. Diante disso, torna-se necessário à reflexão do impacto dessa relação nos modos de adoecer e de cuidar-se em nossa sociedade contemporânea. Objetivo: Compreender a percepção estética do corpo feminino em mulheres praticantes de Crossfit e sua relação com os modos de cuidar de si e da saúde. Métodos: O estudo é uma pesquisa de campo, de natureza básica, com objetivos exploratórios e descritivos e abordagem qualitativa. Foi realizada virtualmente, por meio do Google Meet, no período de junho de 2021 e contou com a participação de mulheres na faixa etária de 20 a 40 anos, que frequentam um box de Crossfit credenciado pela modalidade, localizado no município de Fortaleza-CE. Os dados foram coletados por meio de um roteiro de entrevista semiestruturado e foram analisados através da análise de discurso de Minayo. Resultados: Considerou-se que através dos discursos surgiram categorias que trouxeram aspectos relacionados as cobranças e motivações envolvidas na construção do corpo e a busca incansável do padrão, assim como também, a influência do social na prática física, o cuidado de si e a autoeficácia, como estimuladores do bem-estar físico e mental e os impactos da pandemia na prática de exercícios físicos. Considerações Finais: Os elementos trazidos possibilitaram a percepção de quanto o corpo e saúde são alvos do dia a dia da mulher, a prática de cuidado e a busca estética de um corpo que se encaixe no padrão é algo que tem um poder muito forte, e o quanto o público feminino sofre desde muito cedo com os padrões ditados pela sociedade.

Palavras-chave: Estética Corporal. Corpo Feminino. Saúde da Mulher. Crossfit. 


\section{Introdução}

Em uma sociedade tão marcada pela exaltação da beleza, culto aos cuidados corporais e a qualidade de vida, podemos perceber a repercussão quanto aos cuidados com o corpo, que tanto fala e em alguns momentos grita por socorro com tantas mudanças que a sociedade procura impor sobre ele. A preocupação demasiada em deixá-lo perfeito, um jogo de aparências e quem parece ganhar nessa disputa é quem mais se submete ao processo desenfreado pela conquista do corpo considerado como ideal, com aspectos magros, torneados e esbeltos.

Diante do exposto, Vieira e Bosi (2013) acrescentam que o corpo procura por um amoldamento aos padrões impostos pela sociedade atual. A propagação de corpos saudáveis, sarados, trincados, poderosos e joviais é a declaração de uma busca incansável de aperfeiçoamento para o corpo magro, em contraponto com a gordura, com grandes incompatibilidades para o desenvolvimento de subjetividades.

A imagem corporal que temos sobre a mulher, mesmo após anos, ainda continua sendo relacionada a beleza, saúde e juventude. Corpos estes que vivem e sobrevivem a busca de corresponder o desejo do outro, precisam estar trabalhados, lutando contra o esforço da rotina e o seu envelhecimento. Partindo deste contexto, exponho que chegamos em uma época que se tornou um dever moral da mulher continuar e se esforçar ao máximo para cuidar do seu corpo.

Ainda com relação ao campo da exaltação do corpo feminino, podemos destacar que este mesmo corpo já passou por muitos processos de mudanças. Ainda podemos lembrar com clareza que há algumas décadas atrás o corpo da mulher considerada perfeito era aquele que apresentava mais gorduras, o peso corpóreo estava diretamente associado a contextos de condições financeiras, quem pesava mais, era alguém provido de maior recurso, socioeconomicamente falando. Posteriormente, tivemos uma mudança radical, saímos de um corpo gordo, para o corpo com traços extremamente magros, as mulheres das passarelas ganharam destaque e se tornaram referências para outras mulheres na época, seguindo para a próxima etapa de mudanças, tivemos a fase em que as mulheres em trajes de banhos e roupas mais ajustadas ao corpo eram o novo estereótipo de mulher, a supervalorização dos 
aspectos infantilizados, e atualmente, temos a mulher que se encontra na busca por ter um corpo musculoso, considerado como saudável, uma alimentação regrada, um ser a ser notado e considerado como forte, quase que como um padrão de Mulher Maravilha, personagem fictícia de história em quadrinhos da DC Comics. Não há dúvidas que esta oscilação do corpo perfeito vem trazendo efeitos nocivos acerca dos cuidados com a saúde física e psicológica de inúmeras mulheres no mundo todo.

Para além da imagem que se formou e se forma ao longo dos anos sobre o corpo feminino, é relevante acrescentar que os discursos atuais acerca da temática, seja de médicos, cientistas, midiáticos, dentre outros que estão em ramos associados a temática da beleza, estão cada vez mais repletos de opiniões que apresentam uma invasão ao espaço que deveria ser subjetivo da mulher. A opinião dos considerados especialistas ganha um espaço considerável na mente de tantas mulheres, ditando sobre como o seu corpo deverá ser, quais os procedimentos adequados para atingir aquele objetivo, o que é necessário para atingir o percentual de gordura considerado como o correto pela sociedade atual, começando um processo em que a ação dessas mulheres deverá andar em conjunto com os ideais atuais.

Segundo Novaes e Iannelli (2015), a imagem corporal se relaciona com o julgamento moral que o indivíduo faz sobre a sua própria aparência. Este fator se torna determinador no que diz respeito à forma como o sujeito se aprecia e o que ele fará com o seu corpo, assim como também, no desenvolvimento de sua identidade.

Quando correlacionamos a prática do cuidado de si, este trabalho traz a modalidade do Crossfit, esclarecendo que nos últimos anos, essa atividade física vem sendo mais procurada devido a sua intensidade, rotatividade de exercícios, mudanças estéticas corporais e o auto desafio, sendo procurada atualmente, por um número maior de mulheres. Porém, o público masculino ainda apresenta maior destaque dentro do box da modalidade, com relação a faixa etária. O Crossfit se destaca por incluir todas as idades, os treinos diários realizados em grupo, podem ser totalmente adaptados para cada realidade. A busca pela prática se dá por meio de diversas motivações e busca por mudanças, e que como atividade física, traz diversos benefícios para a saúde. 
Diante dos contextos citados acima quanto às diversas características sobre o corpo feminino, a presente pesquisa buscou problematizar a visão estética do corpo feminino na promoção da saúde das mulheres, de modo que as formas como as mulheres percebem seus corpos possam nos dar direções sobre o cuidado de si e as relações desse cuidado com o processo saúde-doença.

A proposta de pesquisa surgiu a partir de um interesse pessoal da pesquisadora, sobre a relação da atividade física com a percepção estética do corpo feminino e a repercussão na saúde da mulher. Hoje, sou praticante da modalidade e possuo um maior contato com o público feminino na faixa etária de 20 a 40 anos que praticam o Crossfit, e percebeu-se discursos que apresentavam uma preocupação com o corpo e a busca contínua por melhorias nos aspectos físicos e mentais.

As contribuições no âmbito científico e social são expostas pela necessidade de entendermos melhor as interfaces entre a busca incessante das mulheres por um corpo "adequado", idealizado e condicionado a um padrão estético externo e a escolha das práticas e dos modos de cuidar de si, contextualizando essas relações no cenário de pandemia em que estamos vivenciando, onde a discussão da atividade física e os exercícios ainda encontram-se persistentes em diversas regiões do Brasil, porém, após longas lutas do Conselho Federal de Educação Física (CONFEF), os exercícios físicos foram considerados como serviços essenciais em algumas cidade do nosso país. As tais atividades foram consideradas relevantes, por apresentarem um papel importante na prevenção de doenças mentais e físicas da população brasileira, se tornando pertinentes na promoção constante do cuidado na saúde pública.

Com base no exposto, essa pesquisa levanta a seguinte questão norteadora: Como a percepção estética de corpo feminino pode influenciar nos modos de cuidar de si e na sua saúde? A aquisição de novos conhecimentos acerca da temática é relevante para mulheres, profissionais e alunos de diversas áreas da saúde e pesquisadores, abrindo espaço para que se estude cada vez mais sobre a prática do Crossfit relacionada a saúde física e emocional da mulher. 


\section{Objetivo}

Compreender a percepção estética do corpo feminino em mulheres praticantes de Crossfit e sua relação com os modos de cuidar de si e da saúde.

\section{Métodos}

O estudo é uma pesquisa de campo, de natureza básica, com objetivos exploratórios e descritivos e abordagem qualitativa durante o mês de junho de 2021. O público-alvo indicado para participar da pesquisa foi de 05 (cinco) mulheres na faixa etária de 20 a 40 anos de idade, praticantes assíduas (5x ou 6x por semana) a 01 (um) ano na modalidade Crossfit e que sejam indicadas pelos coachs (instrutores da modalidade) para participarem da pesquisa. Esta faixa etária foi selecionada a partir da observação de uma adesão significativa de mulheres nessa faixa etária.

Assim, foram incluídas na pesquisa mulheres na faixa etária de 20 a 40 anos de idade, que fossem praticantes a 01 (um) ano de Crossfit, que treinassem de forma assídua (5x ou $6 x$ por semana) dentro do box, e que foram indicadas pelos coachs do referido box.

Foram excluídas mulheres com faixa etária menor de 20 anos e maior que 40 anos que não praticam assiduamente (menos de $5 x$ na semana), que não estejam praticando a modalidade Crossfit a 01 (um) ano, que não sejam alunas da modalidade ou que não foram indicadas pelos coachs do box.

Devidos ao quadro pandêmico, a coleta de dados ocorreu virtualmente através do aplicativo Google Meet, onde foi disponibilizado um link de reunião do referido aplicativo para cada participante, e por meio dele foi aplicado um roteiro de entrevista semiestruturado, que teve como estrutura um cabeçalho para identificação e 08 (oito) perguntas que buscaram responder à questão problema desta pesquisa. A coleta foi realizada no mês de junho de 2021 no horário e dia agendado pela pesquisadora.

Foi solicitado o uso de um gravador do próprio celular da pesquisadora durante o processo de entrevista, para que os discursos pudessem ser gravados para 
posteriormente serem armazenados, transcritos e implantados os nomes fictícios, visando a preservação das identidades das participantes, informo que foram dadas as participantes os nomes de treinos realizados no Crossfit que carregam nomes de mulheres.

Para a análise e interpretação de dados foi utilizada a análise do discurso de Minayo (2012). Essa análise é dividida em três contextos de conhecimento, primeiro o materialismo histórico, segundo a linguística e terceiro, a teoria do discurso. A partir dessas três áreas foi possível perceber o sentido que as palavras têm e como elas são construídas de maneira histórica e possuem expressões de ideologias, fazendo com que para além dos significativos lexicais da fala, possa ser entendida no contexto em que ela foi inserida. Trazendo à tona a relevância do discurso, mas também, do texto produzido, acrescentando além disso, os silêncios, que também falam (LIMA et al., 2014).

A presente pesquisa está em conformidade com a Resolução 466/2012, que subentende normas aplicáveis a pesquisa realizada com seres humanos, lhes garantindo ética e respeito pela dignidade humana como num todo durante o processo de construção desta pesquisa. O estudo submetido ao Comitê de Ética em Pesquisa da Universidade Estadual do Ceará sob o parecer nº 4.712.093 (BRASIL, 2013).

Para a garantia do anonimato das participantes, foi disponibilizado pela pesquisadora uma lista com nome de treinos de Crossfit que possuem nome de mulheres para que elas pudessem escolher como gostariam de ser chamadas. Os nomes escolhidos foram: Amanda, Annie, Fran, Gwen e Isabel.

\section{Resultados e Discussão}

A amostra desta pesquisa foi composta da participação de 05 (cinco) mulheres adultas com faixa etária de 27 a 35 anos, praticantes assíduas (5x ou 6x por semana) no box, e que treinam Crossfit a um ano ou mais. Quanto a situação conjugal, quatro mulheres eram solteiras e uma era casada. O nível econômico de acordo com o bairro onde residem e se desenvolvem atividade remunerada apresentaram que todas 
as participantes moram em bairros de classe média e desempenham atividades remuneradas.

As categorias foram formadas a partir da leitura prévia da transcrição das entrevistas, buscando correlacionar os discursos trazidos com os objetivos desta pesquisa, as seguintes categorias visam apresentar um núcleo de sentido, valorizando a fala das participantes, que são repletas de significados e, trazendo como referência autores relevantes das temáticas apresentadas.

\section{Metamorfoses corporais: as cobranças como motivação para a construção do corpo estético e a busca incansável do corpo feminino padrão no mundo do Crossfit}

A partir dos diversos discursos apresentados pelas participantes nas entrevistas, esta categoria surge a partir de aspectos relevantes que estão associados as necessidades de alterações corporais radicais no decorrer da vida dessas mulheres e que fizeram com que houvesse um processo de motivação interna para mudança de hábitos e a busca pelo corpo considerado como padrão pela nossa sociedade.

\footnotetext{
O que se apresenta nesse jogo não é somente o corpo, mas certamente o que tê-lo significa. Em meio à realimentação da ideia do self-made man, do homem que deve supostamente inventar a si próprio na tentativa de não ser simplesmente uma figura a mais do rebanho, o corpo do indivíduo se torna um produto para dar conta do "como eu quero que as pessoas me vejam", fortalecendo uma ideologia da estética corporal (LUCENA; SEIXAS; FERREIRA, 2020, p. 4).
}

A existência de aspectos nesse contexto, associados a processos de embelezamento e anseio pelo corpo ideal interferiram diretamente nas suas relações com o corpo e a forma como se viam. Lucena; Seixas e Ferreira (2020) apontam que, diante dos mais diversos avanços da tecnologia e da ciência, arriscamo-nos a debater se há limites na busca desse algo faltoso, será os músculos, a barriga trincada ou qualquer outra alternativa que represente a falta.

Nesse sentindo, trago alguns relatos que explanam acerca de alguns sofrimentos psíquicos as quais as participantes foram submetidas na faixa etária da juventude e que tiverem efeitos até a vida adulta: 
Foram 17 anos com pessoas querendo que eu emagrecesse, as pessoas querendo que eu fizesse isso, as pessoas jogando minhas roupas fora, as pessoas falando um monte de coisa, as pessoas falando que eu comia demais, aí eu falei eu vou mudar, fiz uma análise de todos os meus erros que eu tinha passado, e agora eu vou fazer o certo, vou para a nutricionista e vou treinar feito uma quen**, aí foi quando eu comecei a me encontrar, depois que eu entrei no Crossfit e na faculdade de moda (Fran).

Eu já fui muito magrinha, dos 50 fui para o 75 e fiquei com 75 até mais ou menos uns 25,26 anos ficava sempre nesse processo, de tentar alguma coisa para emagrecer, emagrecia, tomei remédio, um até que foi proibido, aquela sibutramina, então sempre eu estava tentando formas mais fáceis de botar esse corpo num padrão mais magro assim (Isabel).

Eu sempre fui uma criança gordinha, de ser roliça, mas meu corpo começou a me incomodar na adolescência quando vi que talvez eu não atingisse um padrão (Gwen).

A primeira palavra que vem quando falo sobre corpo é cobrança, né assim, pressão estética (Isabel).

Nesta perspectiva, podemos perceber que as mulheres na maioria das vezes utilizam-se de diversos meios para atingir o padrão estético atual, se submetendo a dietas restritivas e a utilização de medicamentos para emagrecimento, focando apenas na estética corporal sem pensar sobre aspectos voltados para a saúde. Para além desse fator, podemos perceber também, concepções externas que favoreciam o comportamento de emagrecimento imediato. Lucena; Seixas e Ferreira (2020) complementa esse contexto trazendo que:

Entretanto há sempre um “a mais" nessa busca, pois esse ideal engloba muito mais do que a variação de alguns quilos a mais ou a menos. Tal busca envolve uma maneira de ver, de ser e de ser visto, determinando como uma pessoa se encaixa no jogo de sua vida.

Podemos perceber que as dietas estão diretamente relacionadas com o objetivo de atingir o padrão do corpo perfeito, o “a mais" só podia ser alcançado se esse corpo se submete a procedimentos que geravam sofrimentos, mas que ao mesmo tempo estão diretamente relacionados ao sentimento de satisfação e valorização do corpo. Cada dia mais surgem procedimentos estéticos e atividades físicas que estimulam práticas irreais e que exigem uma tortura física e psicológica, levando a um cuidado corporal doloroso, que depende de privação de alimentos fundamentais, até exposição física desnecessária na busca do corpo "ideal”. 
O que se relaciona assim ao fato da grande procura por práticas de atividade física, no entanto, apesar dos indivíduos já apresentarem índices de massa corporal e percentual de gordura adequados, muitos praticantes, visualizam uma imagem corporal idealizada, buscando um constructo ideal da imagem do tipo físico corpóreo (ULIANO; SILVA, 2019, p. 4).

Essas práticas supracitadas decorrentes da insatisfação com a aparência, tem trazido o quão é importante dialogarmos sobre distúrbios psicológicos ligados a fatores alimentares, como exemplo, anorexia, bulimia, transtorno dismórfico corporal, como também, transtornos psicológicos, como, ansiedade e depressão.

Eu pensava muito em dieta para emagrecer e ficar magra e me restringia (Annie).

Fiz dietas, mais dietas, emagrecia e engordava, emagrecia e engordava, até que em 2017 cheguei no auge de pesar 100 quilos, eu praticamente nem me olhava mais no espelho, eu sou soube que estava com 03 dígitos na balança quando cheguei no médico, eu era completamente sedentária (Gwen).

Sempre foi com o objetivo de melhorar meu corpo, sempre, passando por tudo que tu imaginar de restrição né? De dieta muito restritiva, de chegar num período muito magro e não me ver daquele jeito (Isabel).

[...] Dieta para ter um corpo mais saudável e aí eu comecei nessa época a fazer dietas muito restritivas, aí eu fiz uma dieta chamada Whole 30, que basicamente é uma dieta paleolítica, aí eu fiz essa dieta e emagreci muito, tipo 10 quilos em um mês, emagreci muito, mas fiquei com transtorno alimentar, eu desenvolvi bulimia (Annie).

Diante disso, pode-se considerar também que as cobranças corporais serviram para estas mulheres como motivação para melhorias corporais, Weinberg e Gould (2008) trazem que, estipular objetivos é considerado como uma tática motivacional benéfica para melhorias de comportamentos vinculados a aderência das práticas físicas.

Mesmo que inicialmente essa motivação se dê por finalidades estéticas, tendo em vista, que o público feminino é o alvo principal do mundo da beleza, sendo uma das formas da mulher se encaixar na sociedade e ser aceita, uma aceitação não apenas do outro, mas de si. Seguindo um conceito de que, se eu me encaixo no padrão da sociedade, logo, existo, logo, faço parte.

$\mathrm{Na}$ era atual, as representações de corpo estão voltadas para o magro, jovem e belo, associando o sujeito a crença de poder e sucesso, por meio disto, a um processo 
de aceitação do sacrifício submetido ao corpo, seguindo ordens dos padrões, objetivando a ideia da associação corpo x troféu. Santos et al. (2019) complementam o que foi explanado acima apresentando que, as pessoas que não seguem o fluxo de boa forma e boas práticas de alimentação são considerados pela sociedade como indivíduos revolucionários e descuidados, sendo classificados como fora da norma padrão.

Antes eu era mais para estética, eu pensava muito na estética né? Na magreza, enfim, porque para mim corpo bonito era o magro (Annie).

Eu já tive um período, que tinha sido o auge da magreza e beleza, isso também $\mathrm{f}^{* *}$ com a minha cabeça, porque todo mundo me tratava de uma forma e depois que eu engordei todo mundo passou a me tratar de outra forma (Fran)

Na verdade, a minha infância, adolescência e juventude o meu corpo sempre foi $o k$, e a partir dos 20 e poucos eu engordei mais ou menos uns 15 quilos e a partir disso eu comecei a tomar consciência do meu corpo, comecei a me cuidar, fui buscar emagrecimento, atividades físicas (Gwen).

Bem de estética mesmo, a minha vida inteira eu lutei muito com braço gordo, perna gorda, e aí em todo esse processo eu descobri que eu consigo sim com exercício e alimentação mudar isso (Gwen).

Quando trazemos a discussão acerca das mudanças corporais vinculadas com o motivo para escolha da modalidade, a primeira referência de estímulo vem o corpo da mulher praticante de Crossfit:

O que me motivou inicialmente foi estética, eu não estava atrás de um exercício que eu me identificasse, e eu tinha muito preconceito com o Crossfit (Gwen).

Mas eu tinha na cabeça que eu tinha que estar num padrão, eu tinha que estar magrinha, tinha que estar com a barriguinha definida, e eu tinha que ter o peito grande, não estava respeitando a minha fisiologia mesmo, do meu corpo, né? (Isabel).

Eu via que o corpo do pessoal era muito atlético; era uma galera trincada, aí eu, eita pau, eu acho que o primeiro objetivo foi estético (Annie).

A priori o que me motivou foi a estética, eu via que as mulheres do Crossfit tinham um corpo muito bonito, todo mundo trincado, braço forte e tal, mas depois de um tempo, que a gente vai caindo na realidade, aí acaba se tornando mesmo a atividade, a atividade é um negócio que realmente me prende (Gwen). 
Podemos perceber o quanto que a modalidade está diretamente correlacionada ao corpo estético e malhado, sendo referência de padrão para as participantes. Contamos com um local que respira hormônios e desfile de beleza associada a força. Por trás de um discurso de saúde pode-se estar escondido o poder que a "boa forma" traz, a autoestima de se estar em um corpo que se encaixa no padrão do local e a vinculação corporal com os pares.

Na busca constante por uma maior qualidade de vida e construção de uma bela imagem corporal, o treinamento de força tem como um dos seus objetivos trazer ao praticante ganho de massa muscular e perda de gordura, resultando assim em um corpo mais esbelto, chegando mais próximo ao padrão estético imposto pela sociedade, sendo uma ótima escolha aos indivíduos que têm como fator motivacional a estética (ULIANO; SILVA, 2019, p. 3).

Como já foi exposto acima, podemos considerar que os "corpos referência" podem ser indicadores de motivação, mas podemos considerar também a busca insaciável de um corpo que precisa continuar se submetendo a diversas restrições para ser atingido, trazendo sensações de desajuste e incapacidade.

A comparação ganha forma, e o corpo acaba sofrendo distorções da autoimagem, o corpo precisa se encaixar melhor, sempre tem algo para ser mudado. Uliano e Silva (2019) acrescentam que praticantes de exercício físico, podem apresentar distorções perceptivas da imagem corporal em razão de um anseio de um corpo que possui baixo percentagem de gordura. Podemos perceber claramente através dos discursos abaixo essa necessidade:

Treinando eu quero só perder meu percentual de gordura (Fran).

A questão da mudança é uma coisa muito limítrofe entre o que eu mudaria e o que eu quero mudar, sempre muito presente, eu nunca realmente estou satisfeita e eu atestei isso mesmo de vias de fato (Gwen).

O que eu venho mudar a um tempo que é a questão da composição corporal, reduzir mais o meu percentual de gordura, e ficar com o corpo mais dentro dos padrões da normalidade, acho que principalmente a questão do abdômen, de perder um pouco mais de gordura no abdômen e nos braços que são onde mais incomodam (Amanda). 
Os impactos das mudanças corporais podem ser considerados tanto positivos como negativos, podemos considerar que para além de fatores externos, como citado no parágrafo acima, as mudanças estéticas podem também surgir a partir de uma motivação intrínseca. O corpo é considerado como uma obra inacabada e é construído a partir de diversos aspectos e contextos, sendo passível de metamorfoses físicas do sujeito, podendo ser mudada através de sua identidade para seguir questões sociais, para que então possa ser aceito da melhor forma.

Tinha que ter a uma mudança interna também, para eu poder conseguir alcançar né essa minha mudança externa, mas aí eu tinha que foi um processo muito $\mathrm{f}^{* *}$ de autoconhecimento (Fran).

\section{A família Gurkha: a influência do aspecto social na prática física}

Os seres humanos são considerados seres sociais, e no esporte não tem como ser diferente, apesar de que hoje contamos com diversas modalidades de treino individualizados, como Weinberg e Gould (2008) apontam, que atividades de grupo fornecem a sensação de satisfação, apoio e incentivo de continuar e comparar seu condicionamento e aperfeiçoamento com os de outros indivíduos, um dos motivos principais das pessoas para a prática de exercícios físicos é a associação.

Quando se faz parte de um grupo, há uma satisfação gerada a partir de uma necessidade natural existente no ser humano, e que também proporciona benefícios físicos e psicológicos. Lima (2018) evidencia que, dentro do box de Crossfit é bastante comum as pessoas gritarem quando algum aluno consegue fazer um movimento que não tinha realizado antes. Isso é mais um fator que contribui para o envolvimento e a sensação de pertencimento aquela local e aquela comunidade, a demonstração de cuidado do outro através da torcida pelas pequenas vitórias conquistadas.

Hoje eu vejo o Crossfit como um local em que eu vou fazer atividade com amigos, com pessoas, conhecer gente nova, fiz vários amigos por causa do Crossfit, então é um ambiente de bem-estar (Annie).

O Crossfit é uma modalidade totalmente grupal, desde a chegada ao box até a saída dele, alguns treinos são realizados em dupla, existem competições mundiais 
feitas em grupo e para além disso, entramos novamente na questão da comparação, que nessa categoria, podemos considerar também como algo positivo, o progresso e melhorias no condicionamento vem por meio da motivação que o outro traz do se desafiar. Lima (2018) evidencia que os vínculos sociais no Crossfit exercem também a função de incentivar as novas conquistas, mas como também, para aliviar os momentos de fracasso.

O social impacta diretamente não somente na decisão para adesão a modalidade, mas como também, na segurança para execução de novos movimentos, para a sensação de pertencimento ao local e a motivação para vencer novos desafios encontramos diariamente através dos treinos.

Eu tinha que fazer o Crossfit porque era uma coisa muito dinâmica, eu sou uma pessoa muito extrovertida, de gostar de se comunicar o tempo inteiro, quando eu vi essa questão da comunidade, e principalmente a questão de se desafiar, eu percebi que realmente era aquilo (Gwen).

Outro fator relevante quando trazemos o aspecto social, é o impacto que o próprio ambiente que é chamado de box proporciona para os seus praticantes, surge um sentimento de acolhimento, se tornando um local de socialização, de conhecer novas pessoas.

Os fatores ambientais podem ajudar ou impedir a participação regular em atividades físicas. Esses fatores incluem o ambiente social (p. ex., família e amigos), o ambiente físico (p. ex., clima, pressões de tempo e distância dos recursos) e características da atividade física (p. ex., intensidade e duração da série de exercícios) (WEINBERG; GOULD, 2008, p. 447).

Os fatores indicados acima para a vinculação com a modalidade, estão claramente associados ao contexto social, a comunidade, o ambiente e as características dos treinos, todos dependem de pessoas para existirem. A partir da fala abaixo, expomos que o treino se torna uma consequência de estar ali.

Hoje é mais social do que o próprio treino. Acaba o treino e fica todo mundo ali conversando um pouco, tem aquela hora para mim (Isabel). 
Não existiria o Crossfit sem a união entre as pessoas, a modalidade se autopromove através da venda de viver em comunidade, oferecendo um espaço para criação e fortalecimento de vínculos associado aos cuidados com a saúde e desafios enfrentados diariamente. Os momentos vividos no pré e pós treino, a interação que existe, são aspectos que diferencia o Crossfit de outras modalidades individuais. A sintonia grupal de diálogo e empenho se torna um dos motivos para a escolha da modalidade.

Nesta categoria fomos capazes de perceber o quanto o social é importante, e o quanto ele está associado ao envolvimento dos sujeitos a ação da aquisição de novas práticas e aos cuidados e fatores associados com a nossa saúde mental e física.

\begin{abstract}
Através dessas experiências relacionais é possível investigar as dimensões sensíveis e intersubjetivas de práticas sociais e de seus desdobramentos na vida em sociedade. Esse querer estar junto, sem finalidade, apresenta-se no box de inúmeras maneiras, tomando diversas formas. Além do próprio momento do treino, quando o esforço individual e coletivo constitui uma dimensão estética, o próprio corpo, as roupas, as marcas, os códigos de sociabilidade são meios de comunicação que produzem esse sentir coletivo (LIMA, 2018, p. 83).
\end{abstract}

\title{
Prática do cuidado de si e autoeficácia: o exercício e a preocupação com a saúde como estimulador do bem-estar físico e psicológico
}

Essa categoria surgiu a partir de uma observação das falas trazidas, que a prática do Crossfit é uma forma que as participantes têm de cuidar de si, relacionando esse contexto com a consciência do autocuidado, como também, um estímulo para a sensação de capacidade e superação própria do sujeito, que chamamos de autoeficácia. Quando a crença da capacidade de realizar alguma atividade se instala no sujeito, à um processo de estímulo e motivação para realizar escolhas e desempenho efetivo em si, assim, espera-se um resultado mais satisfatório, alcançando o êxito.

Autoeficácia é simplesmente a crença do indivíduo de que pode realizar com sucesso um comportamento desejado. A preparação para iniciar um programa de exercícios, por exemplo, pode ser afetada pela confiança que a pessoa tem de ser capaz de realizar o comportamento desejado (p. ex., caminhada, corrida, dança aeróbica, etc.) e manter o comportamento. (WEINBERG; GOULD, 2008, p. 446). 
Sobre esse processo de cuidado de si e autoeficácia, Ferraz (2018) identifica, que o desejo de obter a competência na execução da atividade executada e de se sentir capaz diante dos outros, é uma maneira de internalizar a motivação. Se a competência não existir, então o processo de internalização será eliminado completamente ou apresentará deficiências, gerando a ausência do estímulo para dar continuidade a atividade proposta, mesmo diante de outras pessoas que estimulem a prática.

Podemos perceber de uma forma mais clara o que foi apresentado acima através das falas, que trazem o poder que a autoeficácia e a modalidade em si podem fornecer para um desempenho significativo:

Inicialmente o objetivo era estético, para ficar com aquele corpo, e depois mudou para qualidade, assim, resistência, no caso (Annie).

Eu acho o Crossfit muito fo ${ }^{* *}$, quando eu via, eu falava, nossa muito fo $^{\star *}$ cara, quero subir corda, fazer ginástica, como que eu vou fazer isso (Fran).

Que realmente me motiva é a questão da superação, e vê que eu consigo fazer aquilo ali (Gwen).

Salientamos que os cuidados de si, estão diretamente relacionados também com a saúde mental, quando o cuidado com o corpo surge como ideia principal, podemos questionar quais aspectos motivacionais estão imersos nesse desejo e que levam para o processo de mudanças. A partir das falas abaixo, iremos perceber que não há como separar aspectos físicos dos psicológicos, eles estão interligados e são coo dependentes.

Muitas vezes a gente só se preocupa em cuidar da cabeça e não se preocupa em cuidar do corpo, e para mim, tipo assim, um dia que eu não treino, por exemplo, de manhã, interfere todo o meu dia, porque treinar melhora a minha memória, a minha criatividade, então assim, para mim também é um sinal de autocuidado, você cuidar do seu corpo e da sua mente (Annie).

Quando eu me vi presa dentro de casa, sem ter todo o prazer que o exercício me traz, assim da comunidade, de estar no ambiente, realmente me despertou muita ansiedade e tudo, continuei treinando, porque a atividade física de fato hoje para mim é um extravaso da minha mente mesmo (Gwen).

A forma como a gente se vê e se cuida em termos físicos impacta diretamente na nossa área psicológica mesmo, no nosso bem-estar, naquela sensação de plenitude, então quando a gente tá cuidando do nosso corpo, a gente acaba ficando em sintonia e em harmonia com todo o resto né? (Amanda). 
O meu corpo é minha máquina né digamos assim, se meu corpo não tá bem, a minha cabeça não vai tá bem, se minha cabeça não tá bem, meu corpo não está bem (Isabel).

Quando vinculamos o cuidado de si com a saúde, não podemos desconsiderar que diversos aspectos que foram citados nas categorias acima, como a estética e desempenho físico, se destacam como um dos maiores motivadores para a prática física, porém, é relevante esclarecer que apesar desses fatores citados, trazemos a fala de Ferraz (2018) sobre o Crossfit, que a modalidade envolve alta intensidade e constante processo de adaptação a dinâmica existente na prática, então a motivação intrínseca surge como um fator para a evolução e a superação.

A primeira coisa que vem na minha cabeça quando fala sobre corpo é o binômio de saúde e bem-estar, aquela coisa de sempre pensar no melhor funcionamento do meu corpo (Amanda).

Outro aspecto que surgiu na fala das participantes, é o cuidado de si vinculado ao envelhecimento, a preocupação também surgiu a partir da ideia de se envelhecer, que o esporte como cuidado de si, também se enquadra no cuidado para que o corpo esteja em forma e em movimento para um envelhecimento ativo e saudável.

\footnotetext{
Meu objetivo dentro do Crossfit é melhorar cada vez mais, porque quer queira quer não, agora que vão envelhecer as primeiras pessoas praticantes de Crossfit, vão começar a envelhecer, aí é meio que um preparo para a maior idade, a melhor idade, que chamam né? (Fran).

O corpo para mim é sinônimo de bem-estar, mental também, porque tipo, o corpo funcionando normal, bem, a sua mente também funciona bem, o corpo me lembra mais saúde, estar saudável, pensar a longo prazo, na velhice (Annie).
}

Falando ainda sobre o contexto do envelhecimento, podemos considerar que quando cuidamos da saúde, estamos minimizando efeitos noviços que podem aparecer no decorrer da vida. E a prática física se destaca como uma das formas de cuidados, para além de uma questão estética, mas realmente voltada para mudanças de hábitos que visam melhorias na qualidade de vida e bem-estar, visando um processo contínuo de autocuidado. 
O exercício físico também pode ser um ótimo percursor no âmbito das doenças físicas, podendo agir na prevenção, no tratamento e algumas vezes na cura. As doenças cardiovasculares são um exemplo, onde o benefício se encontra na redução da pressão arterial e na melhora da absorção e utilização do oxigênio. Quanto às doenças osteoarticulares, estas são beneficiadas pelo aumento da produção de cálcio e da massa muscular (ULIANO; SILVA, 2019, p. 3).

Outro fator que se destacou nesta categoria, foi uma fala que chegou a nós de uma maneira bastante impactante, arriscamo-nos a apresentar que o cuidado de si também está vinculado ao propósito de vida e a forma como eu desejo ver o meu corpo, quando o sujeito se preocupa com o cuidado de si e os impactos que esses cuidados geram na vida da mulher, isso se torna um fator em destaque para o processo de conscientização da mudança, a partir dessa decisão, há um fornecimento do melhor que o sujeito é capaz de oferecer para o seu próprio corpo.

Meu corpo, ele me transformou para minha liberdade, deu até vontade de chorar velho, porque essa é a verdade (Fran).

Você estando bem você é capaz de ajudar as pessoas que estão ao seu redor, você fica com a energia melhor, você fica mais disposto, quando você tem o autocuidado, o autoconhecimento, você sabe exatamente o que comer, o que botar pra dentro do seu corpo, como melhorar sua saúde, como deixar sua imunidade alta, totalmente atrelado ao bem-estar do seu corpo, com saúde (Fran).

O médico me falou muita coisa, de tipo assim, verdades mesmo, de realidades, tipo, Gwen, olha para você, você é nova, mas a forma como você trata seu corpo é como se você fosse uma pessoa de 50, 60 anos, que não se importa, enfim, e aquilo me fez acordar, e a partir daí, eu realmente fui atrás, essa foi a primeira vez, que eu realmente botei a saúde em primeiro lugar do meu corpo, era uma coisa que me incomodava, o corpo, mas, a motivação inicial mesmo assim realmente fazer isso pela minha saúde (Gwen).

Hoje eu considero que o corpo está dentro do melhor que ele pode ser, eu não brigo mais para me encaixar num tipo de corpo que não é meu, eu hoje entendi qual é o tipo do meu corpo, e que eu só posso melhorar o meu tipo de corpo, eu não posso chegar na nutricionista com uma foto da Gisele que é alta e magra e eu sou outro tipo de corpo, outro biótipo, eu não devo mais me comparar com outros corpos (Isabel).

Eu assisti um documentário chamado Free Solo que era de um cara que queria fazer alpinismo, aquele alpinismo livre, sem nenhum equipamento, aí ele virou vegetariano, ele era bem magrinho, ou seja, ele trabalhou oito anos o corpo dele para ele atingir esse propósito, se a gente for parar para pensar, bailarinas também se lascam, os atletas, a gente pode pegar o melhor atleta, foi aí que eu me toquei que o corpo tem que está atrelado ao propósito (Fran). 
Finalizo diante do exposto acima, que esta categoria acentua que as práticas de atividades físicas, são consideradas relevantes devido a sua contribuição em diversos aspectos que foram apresentados acima, tornando-se pertinente na promoção e cuidado continuado no âmbito da saúde pública da sociedade.

\section{O vilão da atualidade: impactos da pandemia na vida e na prática de exercícios físicos}

Não podemos desconsiderar os impactos que a pandemia do COVID-19 deixou e ainda deixa em nossa sociedade como em um todo, a saúde física e emocional de todos foi afetada, sofremos até hoje os efeitos colaterais de passar meses em distanciamento social, efeitos estes que vão para além de aspectos correlacionados a própria doença física.

A pandemia da COVID-19 impôs a grande parte do mundo a necessidade de se adotar a medida de Distanciamento Social para conter o avanço do vírus. No entanto, essa medida tende a acarretar prejuízos a saúde física e mental das pessoas durante esse período. Dessa forma, a prática regular de Exercícios Físicos surge como alternativa de minimizar os efeitos colaterais do Distanciamento Social na saúde humana (RAIOL, 2020, p. 6).

Nossas participantes apresentaram que também sentiram no corpo as mudanças dessa paralização da vida, que impactou diretamente na rotina de treinos:

Eu me vi na época trancada dentro de casa, sem motivação de não saber quando ia ter uma vida de novo, de poder me exercitar do jeito que eu gosto, me deixava enlouquecida e tipo, sem ter perspectiva nenhuma, então a motivação de treino, tipo assim, vou treinar, para ficar bem e me superar e tal na pandemia não existia, porque eu tava dentro de casa, então pra quê vou me superar se não vai ter nada que vai fazer com que eu me supere? Então foi bem difícil (Gwen).

Impactou porque ano passado eu até fazia exercício físico em casa era uma novidade, então a gente conseguia fazer as aulas, só que eu acho que a gente fez tanto isso. Esse ano eu de fato não consegui fazer atividade física dentro de casa, não conseguia (Annie). 
De fato, não podemos ignorar que os espaços de realização de atividades físicas, em grande parte, são ambientes fechados, com uma maior circulação de pessoas diferentes, compartilhando aparelhos e a liberação facilitada de gotículas de saliva e suor dentro dos espaços, sendo um local mais propício para a transmissão do Corona vírus, por esse motivo as academias e box ficaram bastante tempo sem poderem abrir as portas novamente, mesmo as práticas físicas sendo consideradas em alguns estados como serviços essenciais, devido os impactos na saúde mental e fisiológica das pessoas.

\begin{abstract}
As relações entre esporte e saúde mental são complexas. Junto à urgência das ações no enfrentamento à pandemia de Covid-19, declarada pela OMS em 11 de março de 2020, o interesse pela temática emergiu articuladamente ao confinamento social recomendado pela entidade e adotado por grande número dos países do mundo. Como parte dessa política de proteção, centros esportivos e de lazer, academias, clubes e parques públicos foram fechados ou restringiram seu funcionamento. Sob a condição da pandemia, seja ou não em razão do confinamento, fatores sociais de inúmeras ordens - como a alteração radical de rotina, a crise econômica, o temor pelo adoecimento, a indignação com ações governamentais negligentes quanto à segurança e proteção à vida, a insegurança quanto às condições de trabalho, a expectativa incerta sobre como remediar seus muitos efeitos, não apenas sanitários, a tragédia do montante de mortes e o luto por aqueles conhecidos - concorrem e se entrecruzam ocasionando inauditos sofrimentos, comuns e particulares, com potencial para afetar a saúde mental das pessoas, levando-as aos mais distintos processos de adoecimento e transtornos (BARREIRA; TELLES; FILGUEIRAS, 2020, p. 2).
\end{abstract}

Acerca desse aspecto, vale esclarecer que apesar de todos os fatores negativos que decorreram nessa pandemia, e apesar do exercício físico ser considerado como serviço essencial, necessitamos acrescentar a importante fala de Raiol (2020), que traz alguns esclarecimentos acerca de boatos que surgiram, que praticantes de exercício físico poderiam não contrair a doença devido as suas práticas de treinos diários, a autora ressalta que a prática de exercícios físicos não tem o poder de proteger contra o COVID-19, mas visa auxiliar nas melhorias do sistema imunológico do corpo.

Observamos que as praticantes da modalidade que possuíam uma vida muito acelerada e que treinavam em um local de sociabilidade direta, sofreram os impactos mentais e físicos durante esse período: 
Eu espero que não tenha outro Lockdown, terceira onda (risos), porque eu não sei como é que ia ficar minha cabeça se eu parasse de treinar de novo, é minha válvula entendeu? Mesmo treinando em casa, não é a mesma coisa, eu não tenho a mesma motivação. Pra mim eu preciso sair de casa, preciso ver pessoas, eu preciso estar em relação, treinar sozinha é um pouco ruim, eu não gosto (Isabel).

Da primeira vez eu treinei todos os dias, religiosamente, comendo bem ou não, comendo fritura, comendo salada, eu treino todos os dias, da segunda vez, eu já não consegui, dessa segunda vez, comendo bem ou comendo mal, eu tava muito desmotivada, eu não queria mais treinar, e foi a primeira vez que isso aconteceu comigo em quase 04 anos (Gwen).

A pandemia impactou a minha atividade física no sentindo de limitar, de ter acesso a determinados equipamentos e tipos de treino, a alguns estímulos, porque todo os dias eu pratiquei atividade física (Amanda).

Tornar-se notório que não somente a rotina mudou, mas que a pandemia teve o efeito de reajuste, novas adaptações, não somente de treino, mas de vida, o impacto que a primeira onda teve, foi diferente da segunda. Houve uma redução na qualidade de vida, e até hoje, em meio ainda a uma pandemia, sentimos os prejuízos causados e que vão deixar sequelas no decorrer de muitos anos. Podemos considerar os aprendizados, mas precisamos lembrar do quanto foi e é sofrido viver esse momento.

Já na rotina da população como um todo, trata-se de diagnosticar uma perda de qualidade do movimento que afeta a todos, menos ou mais intensamente, com ressonâncias que merecem reflexão. Seguindo a pista para esse diagnóstico, ainda está para ser ressaltado como os prejuízos à qualidade do movimento têm impactos bem mais ramificados e insuspeitos do que a relação direta com o sedentarismo, o risco de consequência mais imediato do confinamento (BARREIRA; TELLES; FILGUEIRAS, 2020, p. 6).

Para além de questões de saúde física, evidenciamos o abalo emocional que muitas pessoas sofreram e ainda sofrem até os dias atuais, diante das mais diversas incertezas e dúvidas sobre si, sobre o outro e sobre o mundo. O não saber o dia de amanhã e viver sob uma situação de ameaça constante teve seus efeitos psicológicos. Hoje, percebemos o quanto cuidarmos da nossa saúde mental é algo que deve ser fundamental, infelizmente, precisou de uma pandemia para a população se preocupar com esse fator e buscar cuidados com relação a essa área. Hoje podemos perceber o 
quanto as mentes estão confusas, enlutadas e desnorteadas, alvo de transtornos mais comuns, como, depressão e ansiedade.

O cuidado de si hoje, pelo menos no mundo em que a gente vive, envolve muito estado mental (Annie).

A pandemia me deixava ansiosa, estressada, eu comia mais, e me desmotivada para o treino, não deixei de treinar, mas eu treinava muito desmotivada, sabendo que depois aquela sensação de pós treino me deixava muito bem, mas totalmente desmotivada (Gwen).

Esta categoria veio para nós lembrar o quanto somos seres vulneráveis a mudanças, podemos perceber através das falas, de que quando a rotina muda, a mente precisa acompanhar o processo, e as vezes não é fácil, aqui, tivemos uma situação pandêmica que envolveu muitos sentimentos e sensações nunca sentidas pelas participantes, mas podemos considerar que através dos abalos emocionais sofridos por meio dessas mudanças, que os cuidados com a saúde mental começaram a se tornar relevante e considerado como prática de cuidado de si.

Finalizamos essa etapa, a partir de uma análise de tudo que foi exposto. E o que mais podemos destacar, é que o cuidado de si e a prática do Crossfit agem em conjunto na vida de todas as participantes, e que os impactos psicológicos, sofridos tanto em alguma fase da vida, como no período da pandemia, estão diretamente relacionados as percepções da autoimagem e a prática do cuidado da saúde mental dessas mulheres, e que a partir desses fatores, houve um processo de motivação para a busca por um estilo de vida mais adequado, de um cuidado melhor e um olhar mais humanizado em alguns aspectos.

Consideramos que mesmo diante de tanto sofrimento, de tantas batalhas individuais e da exposição de comparação entre o antes e o depois de entrar na modalidade do Crossfit, o que faz essas mulheres vencerem e lutarem com a batalha do corpo, é o próprio desejo de quererem se sentir bem, de buscarem um corpo que lhe agradem, mas que agrade o outro também, uma superação diária, de movimentos, mas também de mudanças corporais e de capacidade física e psicológica, é se reconhecer em alguém que merece ser atingido, apesar de todos os esforços, dedicações, sofrimentos, o que me parece através das falas, é que vale a pena atingir a 
meta do corpo idealizado para que haja um processo de identificação de quem eu sou e de pertencimento ao processo de conquista.

\section{Considerações Finais}

Esta pesquisa possibilitou uma breve compreensão da influência da modalidade Crossfit para a prática dos cuidados de si e análise estéticas em mulheres praticantes. Podemos perceber através dos discursos das participantes, o quanto o corpo e saúde são alvos no dia a dia de muitas mulheres, a prática de cuidado e a busca estética de um corpo que se encaixe no padrão, é algo que tem um poder muito forte e que envolve o mundo feminino de uma maneira impressionante.

Não podemos desconsiderar que o corpo da mulher do Crossfit, está associado com a imagem idealizada que a mulher busca, tendo em vista, que as referências de mulheres praticantes da modalidade possuem um corpo e alimentação em dia, porém, podemos perceber também, que para além de uma prática física os cuidados devem ser contínuos, não apenas por uma questão estética, mas sim, por um estilo de vida saudável e pela busca de vencer desafios diariamente.

Através desta pesquisa foi possível perceber, também, o quanto o público feminino sofre desde muito novo com os padrões ditados pela sociedade, e o quanto isso impacta na vida adulta, diante de tantas idas e vindas corporais, nossas participantes encontraram em sofrimentos vividos, uma maneira de conquistar o corpo que possuem hoje. E aqui, alertamos sobre a importância da constante prática de divulgação de informações acerca de distúrbios alimentares e transtornos mentais associados a busca pela perfeição.

Outro fator relevante, é o quanto a motivação e a autoeficácia são fatores determinantes para as práticas de mudança de vida, porque por meio deles nossas participantes buscam constantemente alcançar seus objetivos todos os dias.

Considera-se que a pesquisa conseguiu, apesar das dificuldades encontradas devido período de pandemia do COVID-19, atingir seus objetivos, respondendo as questões que foram apresentadas anteriormente. Porém, é válido acrescentar que ainda são necessários estudos mais aprofundados e com um maior 
número de participantes, tendo em vista a complexidade do estudo sobre a saúde da mulher correlacionado as práticas de atividades físicas, assim como também, mais estudos voltados para a modalidade do Crossfit.

Espera-se que essa pesquisa produza maior acesso às informações que permeiam a relação estética, beleza, práticas físicas e saúde da mulher, levando-nos à reflexão do impacto dessa relação nos modos de promover saúde e de cuidar-se em nossa sociedade contemporânea. Os conhecimentos sobre esses aspectos podem contribuir para fortalecer a comunidade cientifica com a aquisição de novos conhecimentos, minimizando os tabus e preconceitos associados às mulheres e às praticantes de Crossfit em nossa sociedade. 


\section{REFERÊNCIAS}

ANDRADE, Eliane Oliveira de; GIVIGI, Luiz Renato Paquiela; ABRAHAO, Ana Lúcia. A ética do cuidado de si como criação de possíveis no trabalho em Saúde. Interface, Botucatu, v. 22, n. 64, p. 67-76, mar. 2018. Disponível em: http:/ / www.scielo.br/scielo.php?script=sci_arttext\&pid=S141432832018000100067\&lng=en\&nrm=iso. Acesso em: 24 mar. 2021.

BARREIRA, Cristiano Roque Antunes; TELLES, Thabata Castelo Branco; FILGUEIRAS, Alberto. Perspectivas em psicologia do esporte e saúde mental sob a pandemia de covid-19. Psicologia: Ciência e Profissão, v. 40, p. 1-14, 2020.

BOLSONI, Betania Vicensi. O cuidado de si e o corpo em Michel Foucault: perspectivas para uma educação corporal não instrumentalizadora. In: ANPED SEMINÁRIO DE PESQUISA EM EDUCAÇÃO DA REGIÃO SUL, 9., 2012. Caxias do Sul, Anais [...]. Caxias do Sul: ANPED SUL, 2012.

BRASIL. Resolução n ${ }^{\circ} 466$, de 12 de dezembro de 2012. Dispõe sobre diretrizes e normas regulamentadoras de pesquisas envolvendo seres humanos. Diário Oficial [da] República Federativa do Brasil, Brasília, DF, 13 jun. 2013. Disponível em: http:// bit.ly/1mTMIS3. Acesso em: 18 mar. 2021.

DANNER, Fernando. Cuidado de si e estética da existência em Michel Foucault. Revista Filosofazer, Passo Fundo, v. 32, n. 1, p. 73-94, jan./jun. 2008. Disponível em: https://www.ifibe.edu.br/filosofazer/index.php/filosofazerimpressa/article/view L178. Acesso em: 28 mar. 2017.

FERNANDES, Luís; BARBOSA, R. A construção social dos corpos periféricos. Saúde e Sociedade, São Paulo, v. 25, n. 1, p. 70-82, mar. 2016. Disponível em:

http:/ / www.scielo.br/scielo.php?script=sci_arttext\&pid=S010412902016000100070\&lng=en\&nrm=iso. Acesso em: 20 mar. 2021.

FERRAZ, Pedro André Pinto da Silva Araújo. Regulação motivacional e satisfação de necessidades psicológicas básicas em praticantes de Crossfit. 2018. $114 \mathrm{f}$.

Dissertação (Mestrado em Atividade Física e Saúde) - Universidade do Porto, Porto, 2018.

FERREIRA, Francisco Romão. A produção de sentidos sobre a imagem do corpo.

Interface, Botucatu, v. 12, n. 26, p. 471-483, set. 2008. Disponível em:

http:/ / www.scielo.br/scielo.php?script=sci_arttext\&pid=S1414-

32832008000300002\&lng=en\&nrm=iso. Acesso em: 20 mar. 2021. 
FIGUEIREDO, Débora de Carvalho; NASCIMENTO, Fábio Santiago; RODRIGUES, Maria Eduardo. Discurso, culto ao corpo e identidade: representações do corpo feminino em revistas brasileiras. Linguagem em (Dis)curso, Tubarão, v. 17, n. 1, p. 67-88, abr. 2017. Disponível em:

http://www.scielo.br/scielo.php?script=sci_arttext\&pid=S1518-

76322017000100067\&lng=en\&nrm=iso. Acesso em: 17 mar. 2021.

FOUCAULT, M. Ética, sexualidade e política. Rio de Janeiro: Forense Universitária, 2004.

GERSON, Joel et al. Fundamentos de estética 1: orientações e negócios. São Paulo: Cengage Learning, 2011.

GIL, Antonio Carlos. Como elaborar projetos de pesquisa. 5. ed. São Paulo: Atlas, 2010.

GRANDO, José Carlos. A (des)construção do corpo. Blumenau: Edifurb, 2001.

HEUER, Silvia. "Lazer sério" e CrossFit: as características da "identidade guerreira" em atletas amadores. 2019. 145 f. Dissertação (Mestrado em Educação Física) Universidade Federal do Paraná, Curitiba, 2019.

JORGE, Amanda de Souza. Moda fitness: a cultura do corpo perfeito, evidenciadas por mulheres fitness e com sobrepeso das academias Red Mob Crossfit. 2018. $62 \mathrm{f}$. Trabalho de Conclusão de Curso (Curso de Tecnologia em Design de Moda) Universidade do Sul de Santa Catarina, Florianópolis, 2018. Disponível em: http://www.riuni.unisul.br/handle/12345/6777. Acesso em: 20 mar. 2021.

LIMA, Aline Cristina da S. et al. Desafio do conhecimento. Revista Eletrônica InterLegere, n. 14, p. 1-8, jan./jun. 2014. Disponível em:

https://periodicos.ufrn.br/interlegere/article/view/4873/4272. Acesso em: 16 mar. 2021.

LIMA, Aluísio Ferreira de; BATISTA, Karina de Andrade; LARA, Nadir Lara. A ideologia do corpo feminino perfeito: questões com o real. Psicologia em Estudo, Maringá, v. 18, n. 1, p. 49-59, mar. 2013. Disponível em:

http://www.scielo.br/scielo.php?script=sci_arttext\&pid=S1413-

73722013000100006\&lng=en\&nrm=iso. Acesso em: 22 mar. 2021.

LIMA, Rebeca dos Santos. Experiência comunicativa na prática do crossfit: processos intersubjetivos e estéticos. 2018. 123 f. Dissertação (Mestrado em Comunicação, Cultura e Amazônia) - Universidade Federal do Pará, Belém, 2018.

Disponível em: http://repositorio.ufpa.br/jspui/handle/2011/10262. Acesso em: 20 jun. 2021. 
LUCENA, Bianca Bulcão; SEIXAS, Cristiane Marques; FERREIRA, Francisco Romão. Ninguém é tão perfeito que não precise ser editado: fetiche e busca do corpo ideal. Psicologia USP, v. 31, p. 1-9, 2020. Disponível em:

https://www.scielo.br/j/pusp/a/TT3T5xy4qRyGmL5tFmjdYqN/?format=pdf\&lan $\mathrm{g}=$ pt. Acesso em: 20 jun. 2021.

MINAYO, Maria Cecília de Sousa. Qualitative analysis: theory, steps and reliability. Ciência \& Saúde Coletiva, v. 17, n. 3, p. 621-626, Mar. 2012. Disponível em: https://www.scielo.br/j/csc/a/39YW8sMQhNzG5NmpGBtNMFf/?lang=en. Acesso em: 22 nov. 2020.

NOVAES, Joana de Vilhena. Com que corpo eu vou? A sociedade e usos do corpo nas mulheres das camadas altas e populares. Rio de Janeiro: PUC-Rio: Pallas, 2010.

NOVAES, Joana de Vilhena; IANNELLI, Adriana Machado. A dimensão simbólica do corpo e o fenômeno social da corpolatria. Revista Desafios, v. 2, n. 1, p. 176-189, jul./dez. 2015. Disponível em:

https://sistemas.uft.edu.br/periodicos/index.php/desafios/article/view/1714/pdf . Acesso em: 25 mar. 2021.

RAIOL, Rodolfo A. Praticar exercícios físicos é fundamental para a saúde física e mental durante a pandemia da COVID-19. 2020. Brazilian Journal of Health Review, v. 3, n. 2, p. 2804-2813, mar./abr. 2020. Disponível em:

https://www.brazilianjournals.com/index.php/BJHR/article/view/8463. Acesso em: 22 jun. 2021.

SANTOS, Andreia Mendes dos; COSTA, Fábio Soares da. Filosofia da corporeidade: transversalizações de um corpo intenso de devir. Educação \& Realidade, Porto Alegre, v. 43, n. 1, p. 223-237, mar. 2018. Disponível em:

http:/ / www.scielo.br/scielo.php?script=sci_arttext\&pid=S2175-

62362018000100223\&lng=en\&nrm=iso. Acesso em: 22 mar. 2021.

SANTOS, Manoel Antônio et al. Corpo, saúde e sociedade de consumo: a construção social do corpo saudável. Saúde e Sociedade, São Paulo, v. 28, n. 3, p. 239-

252, set. 2019. Disponível em:

http:/ / www.scielo.br/scielo.php?script=sci_arttext\&pid=S0104-

12902019000300239\&lng=en\&nrm=iso. Acesso em: 20 mar. 2021.

SILVA, Fernanda Celeste da et al. Percepções dos praticantes de Crossfit: um estudo exploratório. Archives of health investigation, v. 10, n. 2, p. 200-208, 22 out. 2020.

SILVA, Maria da Conceição Fonseca. Os discursos do cuidado de si e da sexualidade em Claudia, Nova e Playboy. 2003. 353f. Tese (Doutorado em Estudos da Linguagem) - Universidade Estadual de Campinas, Instituto Campinas, Campinas, 2003. Disponível em:

http://repositorio.unicamp.br/jspui/handle/REPOSIP/268876. Acesso em: 24 mar. 2021. 
SIMÕES, Regina. Corporeidade e terceira idade: a marginalização do corpo idoso. Piracicaba: Unimep, 1998.

TEIXEIRA, Fábio Luís Santos; FREITAS, Clara Maria Silvestre Monteiro de; CAMINHA, Iraquitan de Oliveira. A beleza feminina como poder: desvendando outros sentidos para a construção estética de si. Revista Brasileira de Ciências do Esporte, Porto Alegre, v. 36, n. 2, p. 485-500, jun. 2014. Disponível em: http://www.scielo.br/scielo.php?script=sci_arttext\&pid=S010132892014000200485\&lng=en\&nrm=iso. Acesso em: 22 mar. 2021.

ULIANO, Karla Westphal; SILVA, Carolina Barbosa da. Comparação do nível de satisfação da imagem corporal em diferentes modalidades de treinamento neuromuscular. 2019. 15 f. Artigo (Curso de Graduação em Educação Física) Universidade do Sul de Santa Catarina, 2019. Disponível em:

https://repositorio.animaeducacao.com.br/bitstream/ANIMA/12642/1/TCC.pdf. Acesso em: 20 de mar. 2021.

VIEIRA, Camilla Araújo Lopes; BOSI, Maria Lúcia Magalhães. Corpos em confecção: considerações sobre os dispositivos científico e midiático em revistas de beleza feminina. Physis, Rio de Janeiro, v. 23, n. 3, p. 843-861, set. 2013. Disponível em: http://www.scielo.br/scielo.php?script=sci_arttext\&pid=S010373312013000300010\&lng=en\&nrm=iso. Acesso em: 15 mar. 2021.

WEINBERG, Robert; GOULD, Daniel. Fundamentos da psicologia aplicada ao exercício e ao esporte. Porto Alegre: ARTMED, 2008. 


\section{6}

Utillzação das boas práticas

ao parto e nascimento

realizadas por enfermeiros

obstetras 


\title{
16 UTILIZAÇÃO DAS BOAS PRÁTICAS AO PARTO E NASCIMENTO REALIZADA POR ENFERMEIROS OBSTETRAS
}

\author{
Jhonny Ferreira Neco \\ Lorenna Landim Farias de Queiroz \\ Bruna Nunes Costa Lima Rosado \\ Natália de Abreu Alcântara \\ Valéria Pereira da Silva \\ Emanuela Gomes Falcão
}

\section{Resumo}

Objetivo: Analisar a utilização das boas práticas ao parto e nascimento realizados por enfermeiros obstetras em um hospital terciário de referência no município Fortaleza. Métodos: Estudo transversal, retrospectivo com dados documentais e abordagem quantitativa. Os dados foram coletados em 120 Fichas de Monitoramento da Atenção ao Parto e Nascimento de mulheres que tiveram seu parto assistido por enfermeiros obstetras e residentes de enfermagem obstétrica, no período entre março de 2018 a fevereiro de 2019. O estudo obteve a aprovação do comitê de ética em pesquisa, com o parecer consubstanciado ${ }^{\circ}$ 3.325.377. Resultados: $\mathrm{O}$ estudo revelou mulheres entre 20 a 29 anos de idade, multigestas, com resolução da gestação entre 39 a $<41$ semanas, que são consideradas à termo maturo e, com mais de 6 consultas de acompanhamento de pré-natal. Tiveram a penumbra seguida da massagem e do cavalinho como os métodos não farmacológicos mais utilizados e as posições mais praticadas foram a semi-sentada seguida pela cócoras e sims e mais da metade das mulheres tiveram a preservação da integridade perineal. $\mathrm{O}$ acompanhante esteve presente em quase a totalidade dos partos. Já em relação a adaptação a vida extrauterina, a maioria dos recém-nascidos tiveram o índice de Apgar favoráveis, peso entre $3001 \mathrm{~g}$ a 4000g, com clampeamento do cordão umbilical em tempo oportuno, contato pele a pele imediato e amamentação na primeira hora estimulados. Conclusão: Dentre os partos assistidos, pode-se concluir que as boas práticas, baseadas em evidências científicas, foram asseguradas à maioria das parturientes. Possuindo algumas limitações por apresentar uma realidade de apenas uma maternidade, em um recorte temporal, fazendo-se necessário a disseminação das boas práticas nas instituições voltadas à assistência materno-infantil.

Palavras-chave: Assistência Perinatal. Parto Normal. Humanização da Assistência. 


\section{Introdução}

O processo de parir é considerado como algo fisiológico e instintivo, assistido antigamente por parteiras que atuavam nos domicílios e utilizavam como método de trabalho a própria experiência adquirida. Em algumas situações eram disponibilizados chás medicinais para alívio da dor e palavras de incentivo e conforto, com intuito do controle emocional àquele momento crucial na vida da mulher (SUÁREZ-CORTÉS et al., 2015).

Contudo, com o advento da medicina moderna e o incremento do parto cesáreo, cada vez mais presente nos serviços de saúde (RODRIGUES et al., 2016), o momento do trabalho de parto passou a ser institucionalizado em hospitais, tornandose um processo mecanizado e rotineiro na maioria das vezes, dando-se início às intervenções e a medicalização no processo de parir natural, retirando da mulher seu poder de decisão pelo próprio corpo e a participação da sua rede social de apoio nessa cascata de eventos que englobam o nascimento de três vidas: mãe, bebê e sua rede social de apoio (PEREIRA et al., 2016).

Diante de tais divergências no ambiente hospitalar, a Organização Mundial da Saúde (OMS), enfatiza a importância da condução desse processo a partir do diálogo entre a equipe assistencial e a mulher, sobre todos os procedimentos que irão ser realizados. Dentre eles, a utilização de métodos farmacológicos e não farmacológicos para alívio da dor, presença do acompanhante de livre escolha, como também o contato pele a pele e a amamentação na primeira hora (WORLD HEALTH ORGANIZATION, 2018).

No Brasil, pesquisa demonstrou que nos partos do grupo de risco habitual, menos de um terço pôde se alimentar e/ou utilizou os métodos não farmacológicos para alívio da dor durante o trabalho de parto. Sendo que, somente cerca de $45 \%$ delas, referiram deambular durante o trabalho de parto e tiveram o progresso monitorado pelo partograma, levando a conclusão de que as recomendações são pouco utilizadas no ambiente hospitalar, no que se refere as boas práticas de atenção ao parto e nascimento (LEAL et al., 2014). 
Estudo realizado numa cidade do estado da Paraíba, trouxe que os tipos de violências obstétricas mais sofridas, estão a utilização da Manobras de Kristeller seguida da ausência de técnicas de alívio da dor, do descaso, realização de exames de toque invasivos, constantes ou agressivos, a utilização da episiotomia sem o consentimento informado e o descumprimento da lei com a proibição do acompanhante (NASCIMENTO et al., 2017).

Diante do cenário, o Ministério da Saúde, em 2011 criou a Rede Cegonha com o intuito de assegurar direitos e garantir atendimento de qualidade, seguro e humanizado na assistência materno-infantil. ${ }^{7}$ Recentemente foram atualizadas as Diretrizes Nacionais de Assistência ao Parto Normal, que possuem como principal intuito a qualidade da assistência, corroborando com as novas evidências científicas e com as recomendações da American College of Obstetricians and Gynecologists e da Society for Maternal-Fetal Medicine, demostrando uma maior ênfase na promoção e resgate das características naturais e fisiológicas do parto e nascimento (BRASIL, 2017; THE AMERICAN COLLEGE OF OBSTETRICIANS AND GYNECOLOGISTS, 2015).

Dessa maneira, o enfermeiro obstetra que pelo processo de formação embasado no cuidado e não na doença, desponta como o profissional capacitado e disparador de transformações nos cenários de prática. Através de uma assistência com qualidade, coparticipativa entre usuário e profissional e principalmente embasada pelas evidências científicas (RAMOS et al., 2018; BRASIL, 2020).

Portando, com base nas propostas de assistência humanizada e nas recomendações de boas práticas ao parto e nascimento, surge o seguinte questionamento: Quais boas práticas ao parto e nascimento estão sendo realizada por enfermeiros obstetras em um hospital terciário de referência no município de fortaleza?

O tema pesquisado justifica-se pela própria vivência como residente em enfermagem obstétrica e torna-se relevante, uma vez que busca identificar quais boas práticas estão sendo realizada pelos enfermeiros obstetras durante o parto e nascimento, com o objetivo de analisá-las em um hospital terciário de referência no município de Fortaleza. 


\section{Métodos}

Trata-se de um estudo transversal, retrospectivo com dados documentais e abordagem quantitativa, realizada em um hospital terciário de referência no município de Fortaleza. Desenvolvido com as fichas de Monitoramento de Atenção ao Parto e Nascimento (fichas próprias da instituição, que são utilizadas para monitoramento e acompanhamento dos dados que são coletados para alimentação do sistema da Rede Cegonha) e que estejam de acordo com os critérios de seleção da pesquisa.

Para que fosse possível estabelecer o público do estudo, optou-se por incluir somente os partos que são considerados de risco habitual (Idade materna entre 15 e 35 anos; gestações entre 37 a 41 semanas e 6 dias, sem intercorrência clínicas e/ou obstétrica prévias, como também o peso do neonato entre 2500 a 4000g), já que a enfermagem obstétrica, legalmente, pode atuar e que tenham sido realizados por enfermeiros e residentes em enfermagem obstétrica, durante os meses de março de 2018 a fevereiro de 2019.

Excluiu-se: fichas em que não constava a categoria profissional que assistiu ao parto ou que não estavam completamente preenchidas; óbito materno e neonatal; gestações em que foram classificadas como de baixo risco, mas que após a realização de exames, na admissão ou após a realização do parto, foram constatadas malformações congênitas.

Inicialmente, foram encontradas 1.731 fichas de partos normais realizados durante o período de avaliação do estudo. Após a pré-seleção, foram identificadas 273 fichas em que o parto foi assistido apenas por enfermeiro obstetra ou residente de enfermagem obstétrica, desses, 109 não estavam completamente preenchidas (faltavam a idade gestacional, idade materna, procedência, dentre outros), 35 foram partos de pré-maturos (abaixo de 37 semanas) e 09 de recém-nascido acima do peso (4000g). Por fim, a amostra final compôs-se por 120 fichas.

Os dados foram organizados por meio de digitação no software da IBM SPSS Statistics 20.0, e apresentados na forma de tabelas, com suas respectivas distribuições e porcentagens para análise da pesquisa, em seguida, confrontados com as literaturas pertinentes ao tema. O projeto foi submetido ao Comitê de Ética em 
Pesquisa do Hospital Geral Dr. César Cals, recebendo parecer Consubstanciado n ${ }^{\circ}$ 3.325.377. Os aspectos éticos e legais da Resolução 466/12, estiveram presentes em todas as fases da pesquisa (BRASIL, 2013).

\section{Resultados}

Dentre as 120 fichas de Monitoramento da Rede Cegonha selecionadas para o estudo, o grupo etário (Tabela 1) de maior prevalência foi o de 20 a 29 anos de idade com $(54,2 \%)$ e procedentes da capital (78,4\%). Já em relação ao histórico obstétrico, a maioria dos partos vaginais ocorreu entre as gestações consideradas à termo maturo (39 a $<41$ semanas), com (55\%), multigesta $(53,3 \%)$ e que realizaram mais de 06 consultas de pré-natal, sendo (75\%) durante a gestação.

Tabela 1 - Características dos partos normais realizados por enfermeiros obstetras em um hospital público do Ceará, segundo: dados sociodemográficos e histórico obstétrico, Fortaleza, março 2018 fevereiro 2019

\begin{tabular}{|c|c|c|}
\hline Variáveis/Categorias & $N=120$ & $\%$ \\
\hline \multicolumn{3}{|c|}{ Dados sociodemográficos } \\
\hline \multicolumn{3}{|l|}{ Idade } \\
\hline 15 a 19 anos & 27 & 22,5 \\
\hline 20 a 29 anos & 65 & 54,2 \\
\hline 30 a 35 anos & 28 & 23,3 \\
\hline \multicolumn{3}{|l|}{ Procedência } \\
\hline Capital & 94 & 78,4 \\
\hline Interior & 26 & 21,6 \\
\hline \multicolumn{3}{|c|}{ Dados Obstétricos } \\
\hline \multicolumn{3}{|l|}{ Idade Gestacional } \\
\hline À termo precoce $(37 \mathrm{~s} a<39 \mathrm{~s})$ & 45 & 37,5 \\
\hline À termo maturo (39s a <41s) & 66 & 55,0 \\
\hline À termo tardio (41s a $<42 \mathrm{~s})$ & 09 & 7,5 \\
\hline \multicolumn{3}{|l|}{ Gestação } \\
\hline Primigesta & 56 & 46,7 \\
\hline Multigesta & 64 & 53,3 \\
\hline \multicolumn{3}{|l|}{ Consultas de Pré-natal } \\
\hline Maior ou igual 06 & 90 & 75,0 \\
\hline Menos de 06 & 24 & 20,0 \\
\hline Não realizada & 06 & 5,0 \\
\hline
\end{tabular}

Fonte: Elaboração dos autores. 
Ao se avaliar as práticas obstétrica oferecidas as gestantes no momento do parto, evidencia-se que vários métodos não farmacológicos para alívio da dor foram utilizados, muitos desses associados aos outros em uma mesma paciente, explicando porque os dados variaram. Entretanto, estiveram em maior número de vezes aplicados às pacientes, a penumbra (65\%) dos partos, seguido da massagem (50\%) e do cavalinho $(40 \%)$ do total.

Quanto ao tipo de posição durante o período expulsivo, os dados revelam que a posição semissentada foi a mais utilizada $(65,8 \%)$, seguida por cócoras $(17,5 \%)$ e sims $(5,9 \%)$ do total de partos. Já em relação aos graus de laceração perineal, a maioria das gestantes teve a preservação do períneo em $(45 \%)$ dos partos, seguida por lacerações de $1^{\circ}$ grau e $2^{\circ}$ grau, sendo $(32,5 \%)$ e (21\%) respectivamente.

Em relação a presença do acompanhante de livre escolha, que deve ser um direito garantido à gestante durante todo o período do parto, a pesquisa demostrou que em $(77,5 \%)$ dos partos o companheiro, a mãe, a tia ou alguém de confiança da mulher esteve presente e, em apenas (22,5\%) não houve a presença do acompanhante. 
Tabela 2 - Características dos partos normais realizados por enfermeiros obstetras em um hospital público do Ceará, segundo: métodos não farmacológicos, presença do acompanhante e posição no período expulsivo, Fortaleza, março 2018 - fevereiro 2019

\begin{tabular}{|c|c|c|}
\hline Trabalho de Parto & $\mathrm{N}=120$ & $\%$ \\
\hline \multicolumn{3}{|c|}{ *Uso de métodos não farmacológicos para alívio da dor } \\
\hline $\begin{array}{l}\text { Penumbra } \\
\text { Cavalinho } \\
\text { Bola } \\
\text { Deambulação } \\
\text { Respiração Consciente } \\
\text { Massagem } \\
\text { Musicoterapia } \\
\text { Aromaterapia } \\
\text { Barra de Ling }\end{array}$ & $\begin{array}{l}78 \\
48 \\
16 \\
08 \\
32 \\
60 \\
09 \\
04 \\
21\end{array}$ & $\begin{array}{r}65,0 \\
40,0 \\
13,3 \\
6,6 \\
27,5 \\
50,0 \\
7,5 \\
3,3 \\
17,5 \\
\end{array}$ \\
\hline \multicolumn{3}{|l|}{ Posição durante o período expulsivo } \\
\hline $\begin{array}{l}\text { Cócoras } \\
\text { Semi-sentada } \\
\text { Sims } \\
\text { Litotômica } \\
\text { Em pé } \\
\text { Gasking }\end{array}$ & $\begin{array}{l}21 \\
79 \\
07 \\
06 \\
03 \\
04\end{array}$ & $\begin{array}{c}17,5 \\
65,8 \\
5,9 \\
5,0 \\
2,5 \\
3,3\end{array}$ \\
\hline \multicolumn{3}{|l|}{ Tipos de laceração perineal } \\
\hline $\begin{array}{l}\text { Íntegro } \\
1^{\circ} \text { grau } \\
2^{\circ} \text { grau } \\
3^{\circ} \text { e } 4^{\circ} \text { grau }\end{array}$ & $\begin{array}{l}54 \\
39 \\
25 \\
02\end{array}$ & $\begin{array}{c}45,0 \\
32,5 \\
21,0 \\
1,5\end{array}$ \\
\hline \multicolumn{3}{|l|}{ Acompanhante de livre escolha } \\
\hline $\begin{array}{l}\text { Sim } \\
\text { Não }\end{array}$ & $\begin{array}{l}93 \\
27\end{array}$ & $\begin{array}{l}77,5 \\
22,5\end{array}$ \\
\hline
\end{tabular}

Fonte: Elaboração dos autores.

*A amostra variou, possivelmente, por vários métodos terem sido realizados em uma mesma paciente.

A respeito à adaptação a vida extrauterina e os valores atribuídos após o nascimento, o índice de Apgar demostrou que a maioria dos recém-nascidos teve o valor maior ou igual a oito no quinto minuto $(94,2 \%)$ e que apenas 07 bebês $(5,8 \%)$ tiveram um número menor ou igual a sete no primeiro minuto de vida. Já em relação ao Apgar no quinto minuto, todos os neonatos tiveram um índice maior ou igual a oito. Demostrando que mesmo aqueles que tiveram um Apgar igual ou abaixo de sete no primeiro minuto, todos, apresentaram valores satisfatórios na avaliação subsequente, o que revela uma boa adaptação após o nascimento.

No que concerne ao peso, a maioria nasceu entre $3001 \mathrm{~g}$ a $4000 \mathrm{~g}$, sendo (65\%); o clampeamento do cordão umbilical, em tempo oportuno ocorreu em $(83,3 \%)$, 
o contato pele a pele imediato em $(96 \%)$ e $(81,7 \%)$ dos recém-nascidos foram amamentados na primeira hora de vida.

Tabela 3 - Características dos partos normais realizados por enfermeiros obstetras em um hospital público do Ceará, segundo: Apgar, Peso, Clampeamento do cordão umbilical, contato pele a pele imediato e amamentação na primeira hora, Fortaleza, março 2018 - fevereiro 2019

\begin{tabular}{l|c|c}
\hline \multicolumn{1}{c}{ Cuidados Imediatos ao Recém-nascido } & $\mathbf{N}=\mathbf{1 2 0}$ & $\%$ \\
\hline Apgar no 10 minuto & 07 & 5,80 \\
\hline Menor ou igual 07 & 113 & 94,2 \\
Maior ou igual 08 & 0 & 0,0 \\
\hline Apgar no 50 minuto & 120 & 100,0 \\
\hline Menor ou igual 07 & & \\
Maior ou igual 08 & 42 & 35,0 \\
\hline Peso & 78 & 65,0 \\
\hline 2500g a 3000g & 20 & 16,7 \\
3001g a 4000g & 100 & 83,3 \\
\hline Clampeamento do cordão umbilical & \multicolumn{1}{l}{} \\
\hline Imediato & 115 & 96,0 \\
Oportuno & 05 & 4,0 \\
\hline Contato pele a pele imediato & & 81,7 \\
\hline Sim & 98 & 18,3 \\
Não & 22 & \\
\hline Amamentação na primeira hora &
\end{tabular}

Fonte: Elaboração dos autores.

\section{Discussão}

Os resultados deste estudo proporcionaram identificar e descrever o perfil sociodemográfico das gestantes que tiveram seus partos assistidos por enfermeiros e residentes em enfermagem obstétrica; como também os dados obstétricos; a utilização dos métodos não farmacológicos para alívio da dor; a posição durante o período expulsivo; os graus de laceração perineal e a presença do acompanhante de livre escolha da parturiente.

Corroborando com o estudo, pesquisas, como as de Santana et al. (2019) e Freitas; Narchi e Fernandes (2019) demostram que a faixa etária média das parturientes ficou em torno de 22 anos de idade e procedentes da capital. No que se refere aos dados obstétricos, a maioria realizou o pré-natal, com média de 7 consultas. Em relação à 
paridade, 55,1\% já haviam tido um ou mais partos e a média de idade gestacional foi de 38 semanas e 4 dias (SANTANA et al., 2019).

A utilização dos métodos não farmacológicos para alívio da dor, evidenciou-se que todas as mulheres tiveram pelo menos um tipo de método ofertado durante o período do parto. Podendo-se afirmar que as boas práticas de atenção ao parto foram utilizadas pelos enfermeiros e residentes em enfermagem obstétrica que assistiram as parturientes.

Nesse sentido, dentre as recomendações, as mais atuais incluem: o uso de métodos não farmacológicos para alívio da dor, tais como o banho de aspersão ou imersão em água quente, a massagem, dentre outros; a oferta de líquidos, o estímulo à adoção de posições verticalizadas e à liberdade de movimentação que buscam, principalmente, aumentar o conforto materno e facilitar a progressão do trabalho de parto (BRASIL, 2017; GUIDA et al., 2017).

Entretanto, existem certas dificuldades, ainda presentes, que dificultam a realização dos métodos não-farmacológicos no ambiente hospitalar, como por exemplo a presença de aspectos de ordem cultural, organizacional e estrutural, que interferem diretamente na prática autônoma do enfermeiro obstetra, durante a assistência ao parto de risco habitual (SANTOS et al., 2019).

No que concerne a posição durante o período expulsivo, evidenciou-se que as posições verticalizadas foram as mais estimuladas e a maioria teve a preservação do períneo. O que corrobora com as novas recomendações da Organização Mundial de Saúde (OMS) (WHO, 2018), e dos estudos de Guida et al. (2017); Santos et al. (2019) e Elvander et al. (2015), que enfatizam a liberdade de posição com estímulo de posições verticalizadas para evitar lacerações e, em algumas situações, as técnicas de proteção perineal que contribuem para a redução da perda sanguínea.

Estudo realizado em uma casa de parto natural, correlacionou a posição durante o período expulsivo e os graus de laceração perineal, e encontraram que a posição mais adotada foi a verticalizada, com $84,8 \%$ do total de 164 partos assistidos e, quanto ao número de lacerações, os dados demonstraram que 50,3\% foram classificadas como de $1^{\circ}$ grau, seguidas de $45,4 \%$ de $2^{\circ}$ grau, $14 \%$ com períneo íntegro 
e apenas cerca de 5\% apresentaram laceração de $3^{\circ}$ grau (SCHETTINI; GRIBOSKI; FAUSTINO, 2017).

O acompanhante esteve presente na maioria dos partos, sendo $77,5 \%$ do total de partos, demostrando que, embora não seja a totalidade, o direito ao acompanhante foi oferecido, seguindo as várias recomendações e evidências de estudos na área e o que determina a lei 11.108/05 (BRASIL, 2005).

É o que enfatiza a pesquisa realizada com puérperas primíparas de parto vaginal internadas no Alojamento Conjunto da Maternidade-Escola Assis Chateaubriand, que teve o intuito de correlacionar a influência do acompanhante, a qual evidenciou que a presença do parceiro durante o processo parturitivo foi importante para quase totalidade das puérperas, reforçando a influência positiva do acompanhante para favorecer o fortalecimento do vínculo entre o casal e com o recémnascido (HOLANDA et al., 2018).

Quanto aos dados neonatais após o nascimento, à adaptação a vida extrauterina foi satisfatória, pois todos receberam Apgar $\geq 8$ (maior ou igual a oito) no quinto minuto, embora apenas 5,8 \% tenham sidos classificados com Apgar $\leq 7$ (menor ou igual a sete). Dessa forma, estudo realizado em uma Maternidade do município do Rio de Janeiro, apontou que as mães que utilizaram apenas Tecnologias não Invasivas de Cuidado de Enfermagem Obstétrica (TNICEO), tiveram seus recém-nascidos com Apgar $>8$ (boa vitalidade ao nascimento), sendo 94,5\% de 3.956 partos assistidos por enfermeiros obstetras (VARGENS et al., 2019).

Evidências obtidas em uma pesquisa realizada no Rio de Janeiro, demostraram que dos 367 partos assistidos por enfermeiras obstetras, $88 \%$ tiveram o clampeamento do cordão umbilical em tempo oportuno, 97\% foram colocados imediatamente no corpo materno e $81,7 \%$ foram amamentados (THE AMERICAN COLLEGE OF OBSTETRICIANS AND GYNECOLOGISTS, 2015), tais intervenções são importantes tanto para o bebê quanto para a mãe, pois, fortalecem o vínculo afetivo e familiar e facilitam o processo de continuidade da amamentação (FUCKS et al., 2015).

As boas práticas logo após o nascimento, estiveram presentes na sua grande maioria, evidenciando que se preconizou pelo clampeamento do cordão em tempo oportuno, respeitando e aguardando a adaptação fisiológica ao meio extrauterino, 
tendo o contato pele a pele estimulado imediatamente para favorecer o vínculo afetivo e melhor controle da temperatura do recém-nascido e a amamentação na primeira hora de vida, a qual aumenta as chances de sucesso de sua continuidade, dentre outros benefícios.

Sendo necessário ressaltar que a atenção obstétrica deve-se ser sempre baseada em evidências científicas demandando, sobretudo, o respeito à autonomia nas decisões da parturiente, a inclusão do acompanhante de livre escolha e o cuidado materno-infantil por meio de uma equipe capacitada e atualizada às recomendações pertinentes, visando a adequada humanização da assistência ao parto e nascimento.

\section{Conclusão}

Dentre os partos assistidos pelos enfermeiros obstetras e residentes em enfermagem obstétrica, no cenário de realização do estudo, pode-se concluir que as boas práticas baseadas em evidências científicas, as quais são preconizadas pelo Ministério da Saúde e OMS, foram estimuladas e asseguradas à maioria das parturientes no período analisado.

O estudo possui limitações por apresentar uma realidade de apenas uma maternidade em um recorte temporal, portanto, faz-se necessário a disseminação das boas práticas nas instituições voltadas à assistência materno-infantil.

Espera-se que os resultados deste estudo possam subsidiar uma assistência à parturiente pautada em práticas baseadas em evidências científicas, visando contribuir com a melhoria da atenção obstétrica. 


\section{REFERÊNCIAS}

BRASIL. Lei $\mathrm{n}^{\circ} 11.108$, de 7 de abril de 2005. Altera a Lei $\mathrm{n}^{\circ}$ 8.080, de 19 de setembro de 1990, para garantir às parturientes o direito à presença de acompanhante durante o trabalho de parto, parto e pós-parto imediato, no âmbito do Sistema Único de Saúde - SUS. Diário Oficial [da] República Federativa do Brasil: seção 1, Brasília, DF, p. 1, 8 abr. 2005.

BRASIL. Ministério da Saúde. Diretrizes nacionais de assistência ao parto normal: versão resumida. Brasília, DF: Ministério da Saúde, 2017. 51 p.

BRASIL. Ministério da Saúde. Portaria n ${ }^{\circ}$ 1.459, de 24 de junho de 2011. Institui, no âmbito do Sistema Único de Saúde - SUS - a Rede Cegonha. Diário Oficial [da] República Federativa do Brasil, Brasília, DF, 2011. Disponível em: http://bvsms.saude.gov.br/bvs/saudelegis/gm/2011/prt1459_24_06_2011.html. Acesso em: 10 out. 2019.

BRASIL. Resolução COFEN n ${ }^{0}$ 627/2020. Dispõe sobre a normatização da realização de Ultrassonografia Obstétrica por Enfermeiro Obstétrico. Diário Oficial [da] República Federativa do Brasil, Brasília, DF, 4 mar. 2020.

BRASIL. Resolução ${ }^{\circ}$ 466, de 12 de dezembro de 2012. Diretrizes e normas regulamentadoras de pesquisas envolvendo seres humanos. Diário Oficial [da] República Federativa do Brasil, Brasília, DF, 2013.

ELVANDER, Charlotte et al. Birth position and obstetric anal sphincter injury: a population-based study of 113000 spontaneous births. Pregnancy and Childbirth, v. 15, p. 1-9, 2015. Disponível em:

https://bmcpregnancychildbirth.biomedcentral.com/articles/10.1186/s12884-0150689-7. Acesso em: 21 set. 2021.

FREITAS, Juliana Manoela dos Santos; NARCHI, Nádia Zanon; FERNANDES, Rosa Aurea Quintella. Práticas obstétricas em centro de parto normal intra-hospitalar realizadas por enfermeiras obstetras. Escola Anna Nery, v. 23, n. 4, p. 1-7, 2019. Disponível em:

https://www.scielo.br/j/ean/a/mSWXF8whLGGcWtkN5LRwVfP/?format=pdf\&la ng=pt. Acesso em: 21 set. 2021.

FUCKS, Ingrid dos Santos et al. A sala de parto: o contato pele a pele e as ações para o estímulo ao vínculo entre mãe-bebê. AV Enfermagem, v. 33, n. 1, p. 29-37, 2015. Disponível em:

https://www.researchgate.net/publication/281604799_A_sala_de_parto_o_contato_ pele_a_pele_e_as_acoes_para_o_estimulo_ao_vinculo_entre_mae-bebe. Acesso em: 21 set. 2021. 
GUIDA, Natasha Faria Barros et al. Conformidade das práticas assistenciais de enfermagem com as recomendações técnicas para o parto normal. Rev Rene, v. 18, n. 4, p. 543-50, jul./ago. 2017. Disponível em:

http://periodicos.ufc.br/rene/article/view/20286. Acesso em: 21 set. 2021.

HOLANDA, Sâmia Monteiro et al. Influência da participação do companheiro no pré-natal: satisfação de primíparas quanto ao apoio no parto. Texto \& Contexto Enfermagem, v. 27, n. 2, p. 1-10, maio 2018. Disponível em:

http:/ / www.revenf.bvs.br/scielo.php?script=sci_arttext\&pid=S010407072018000200317. Acesso em: 21 set. 2021.

LEAL, Maria do Carmo et al. Intervenções obstétricas durante o trabalho de parto e parto em mulheres brasileiras de risco habitual. Cadernos de Saúde Pública, Rio de Janeiro, v. 30, p. S17-S47, 2014. Suplemente 2. Disponível em:

https://www.scielo.br/j/csp/a/gydTTxDCwvmPqTw9gTWFgGd/?lang=pt.

Acesso em: 21 set. 2021.

NASCIMENTO, Laís Chaves et al. Relato de puérperas acerca da violência obstétrica nos serviços públicos. Revista de Enferm UFPE On Line, Recife, v. 11, n. 5, p. 20142023, maio 2017. Suplemente 5. Disponível em:

https://periodicos.ufpe.br/revistas/revistaenfermagem/article/view/23355. Acesso em: 21 set. 2021.

OBSTETRIC care consensus $\mathrm{n}^{\circ}$ 2: levels of maternal care. Obsterics and Ginecology, v. 125, n. 2, p. 502-515, Feb. 2015.

PEREIRA, Sinara Santos et al. Parto natural: a atuação do enfermeiro diante da assistência humanizada. Tempus - Actas de Saúde Coletiva, Brasília, DF, v. 10, n. 3, p. 199-213, set. 2016. Disponível em:

https://www.tempusactas.unb.br/index.php/tempus/article/view/1727. Acesso em: 21 set. 2021.

RAMOS, Wania Maria Antunes et al. Contribuição da enfermeira obstétrica nas boas práticas da assistência ao parto e nascimento. Revista Online de Pesquisa, v. 10, n. 1, p. 173-179, jan./mar. 2018. Disponível em:

http:// www.seer.unirio.br/index.php/cuidadofundamental/article/view/6019/pd f. Acesso em: 21 set. 2021.

RODRIGUES, Jeferson Carlos Tolentino et al. Cesariana no Brasil: uma análise epidemiológica. Revista Multitexto, v. 4, n. 1, p. 48-53, 2016. Disponível em: http://www.ead.unimontes.br/multitexto/index.php/rmcead/article/view/174. Acesso em: 7 mar. 2019. 
SANTANA, Ariane Teixeira de et al. Atuação de enfermeiras residentes em obstetrícia na assistência ao parto. Revista Brasileira de Saúde Materno-Infantil, Recife, v. 19, n. 1, p. 145-155, jan./mar. 2019. Disponível em: https://www.scielo.br/j/rbsmi/a/btdZrZ4bXTQpcj6qnyLDxSm/?lang=pt. Acesso em: 21 set. 2021.

SANTOS, Flávia Andréia Pereira Soares dos et al. Autonomia do enfermeiro obstetra na assistência ao parto de risco habitual. Revista Brasileira de Saúde Materno Infantil, Recife, v. 19, n. 2, p. 481-489, abr./jun. 2019. Disponível em: https://www.scielo.br/j/rbsmi/a/fCRbLTMtQycXhjVrHJRQzjm/?lang=pt\#: :text= constatou $\% 2$ Dse $\% 20$ que $\% 20 \mathrm{o} \% 20$ enfermeiro, ainda $\% 20 \mathrm{impostas} \% 20$ pela $\% 20$ hegemo nia $\% 20 \mathrm{~m} \%$ C3\% A9dica. Acesso em: 21 set. 2021.

SCHETTINI, Natália Jardim de Carvalho; GRIBOSKI, Rejane Antonello; FAUSTINO Andréa Mathes. Partos normais assistidos por enfermeiras obstétricas: posição materna e a relação com lacerações perineais espontâneas. Revista de Enfermagem UFPE On Line, Recife, v. 11, p. 932-940, fev. 2017. Suplemento 2. Disponível em: https://periodicos.ufpe.br/revistas/revistaenfermagem/article/view/13462. Acesso em: 21 set. 2021.

SOCIEDADE BRASILEIRA DE PEDIATRIA. Reanimação do recém-nascido $\geq \mathbf{3 4}$ semanas em sala de parto: diretrizes 2016 da Sociedade Brasileira de Pediatria. [S.l.]: Sociedade Brasileira de Pediatria, 2016. Disponível em:

https://www.sbp.com.br/fileadmin/user_upload/DiretrizesSBPReanimacaoRNMai or34semanas26jan2016.pdf. Acesso em: 7 mar. 2020.

SUAREZ-CORTES, Maria et al. Uso e influência dos planos de parto e nascimento no processo de parto humanizado. Revista Latino-Americana de Enfermagem, v. 23, n. 3, p. 520-526, 2015. Disponível em:

https://www.scielo.br/j/rlae/a/CnCH3f9JjpyCsCStbtdrZfS/?format=pdf\&lang=pt. Acesso em: 21 set. 2021.

\section{THE AMERICAN COLLEGE OF OBSTETRICIANS AND GYNECOLOGISTS}

COMMITTEE. Screening for perinatal depression. Obstetrics and Gynecology, v.125, n. 5, p. 1268-1271, 2015. Opinion no. 630. Disponível em:

https://pubmed.ncbi.nlm.nih.gov/25932866/. Acesso em: 24 set. 2021.

VARGENS, Octavio Muniz da Costa et al. Associação entre tecnologias não invasivas de cuidado no parto e vitalidade do recém-nascido: estudo transversal. Escola Anna Nery, v. 23, n. 4, p. 1-8, 2019. Disponível em:

https://www.scielo.br/j/ean/a/nPRsVwT6zKjptkjJtGTdLLs/?lang=pt. Acesso em: 21 set. 2021.

WORLD HEALTH ORGANIZATION. WHO recommendations: intrapartum care for a positive childbirth experience. Geneva: World Health Organization, 2018. 


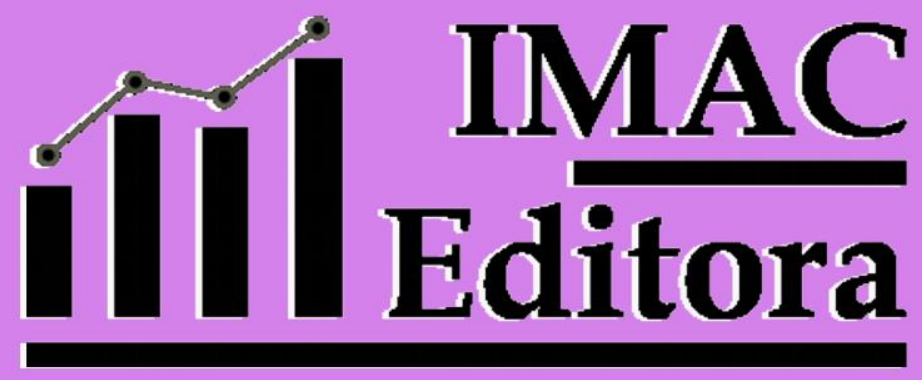

E-mail: contato@editoraimac.com.br Site: www.editoraimac.com.br

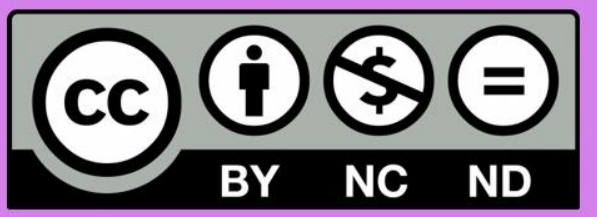

ISBN: 978-65-995347-2-0 